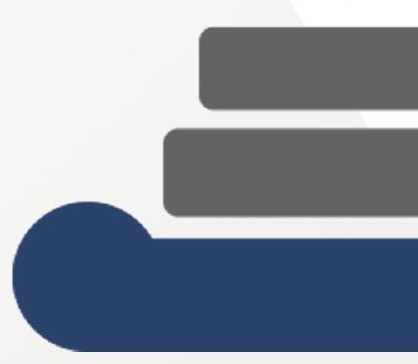

\title{
GOSPODARSKI SUBJEKTI NA TRGU
} IN EVROPSKE DIMENZIJE 2018

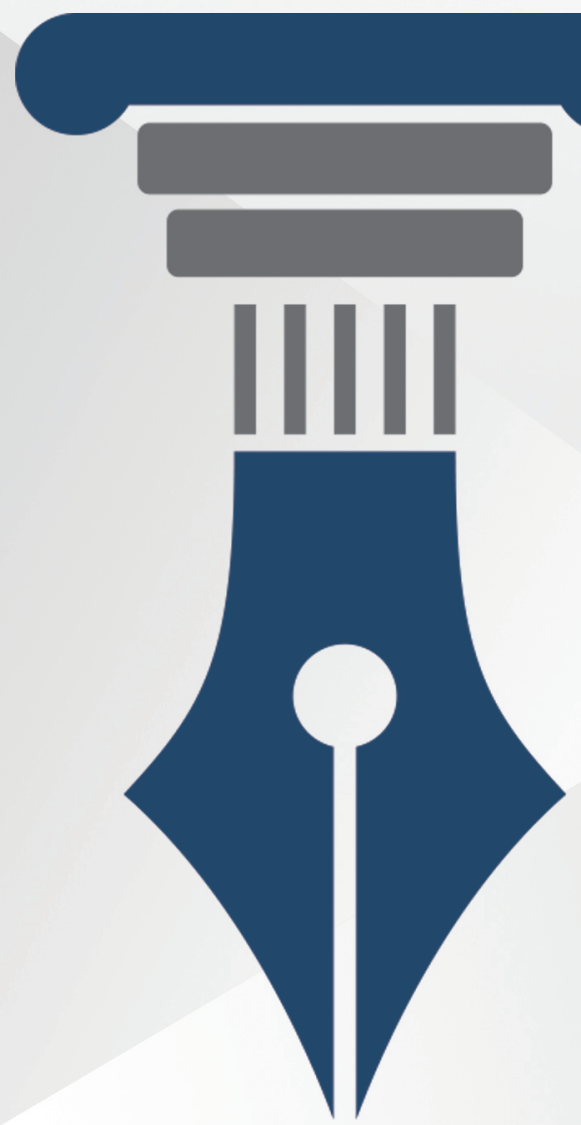

Vesna Rijavec UREDNICA 

Pravna fakulteta

\section{GOSPODARSKI SUBJEKTI NA TRGU IN EVROPSKE DIMENZIJE 2018}


Naslov Gospodarski subjekti na trgu in evropske dimenzije 2018

Titel Corporate Entities at the Market and European Dimensions 2018

Urednica Vesna Rijavec

Editors (Univerza v Mariboru, Pravna fakulteta)

Recenzija Borut Holcman

Review (Univerza v Mariboru, Pravna fakulteta)

Miha Šlamberger

Tehnična urednika

Technical editors

Jan Perša

(Univerzitetna založba Univerze v Mariboru)

Natalija Orešek

(Univerza v Mariboru, Pravna fakulteta)

Oblikovanje ovitka

Cover designer (Univerzitetna založba Univerze v Mariboru)

Grafika na ovitku

Cover graphic

Univerza v Mariboru, Pravna fakulteta

Grafične priloge

Graphic material

Avtorji prispevkov

Založnik / Published by

Univerzitetna založba Univerze v Mariboru Slomškov trg 15, 2000 Maribor, Slovenija http://press.um.si, zalozba@um.si
Izdajatelj / Co-published by

Univerza v Mariboru, Pravna fakulteta

Mladinska ulica 9, 2000 Maribor, Slovenija

https://pf.um.si, info.pf@um.si

\section{Izdaja \\ Edition Prva izdaja}

\section{Vrsta publiakcije}

Publication type

E-knjiga

Dostopno na

Available at

http://press.um.si/index.php/ump/catalog/book/431

Izdano

Published

Maribor, avgust 2019 
To delo je objavljeno pod licenco Creative Commons Priznanje avtorstvaNekomercialno-Deljenje pod enakimi pogoji 4.0 Mednarodna.
This work is licensed under the Creative Commons Attribution-NonCommercialShareAlike 4.0 International License.

$$
\text { https://creativecommons.org/licenses/by-nc-sa/4.0/ }
$$

Avtorji odgovarjajo za jezikovno pravilnost svojih prispevkov v publikaciji.

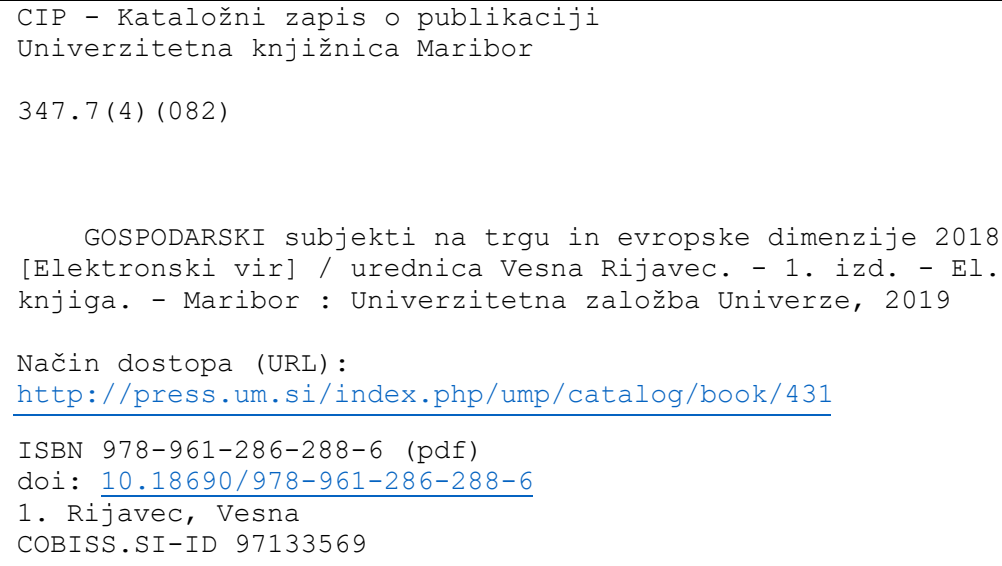

prof. dr. Zdravko Kačič, rektor Univerze v Mariboru 



\title{
Gospodarski subjekti na trgu in evropske dimenzije 2018
}

\author{
VESNA RIJAVEC
}

Povzetek Knjiga z naslovom Gospodarski subjekti na trgu in evropske dimenzije 2018 je znanstvena monografija več avtorjev samostojnih poglavij. Avtorji analizirajo aktualne pravne položaje v zvezi s pametnimi pogodbami, koncerni in pravnim varstvom delničarjev in upnikov, prepletanjem prostorske in gradbene zakonodaje s stvarnim pravom, medijskim pravom, varstvom podatkov po Splošni uredbi o varstvu podatkov (GDPR) itd. Knjiga vsebuje prispevke s področja javnega in zasebnega prava. Avtorji jasno izražajo svoja stališča, razmejitev med povzetimi in lastnimi stališči posameznih avtorjev je jasna. Prav tako se argumentirano spopadajo s stališči v pravni teoriji in sodni praksi, kar povečuje uporabno vrednost monografije. Knjiga predstavlja prispevek k razvoju pravne znanosti.

Ključne besede: • pravo družb $\bullet$ gospodarsko pogodbeno pravo $\bullet$ davčno pravo $\bullet$ delovno pravo $\bullet$ insolvenčno pravo $\bullet$ izvršilno pravo $\bullet$ evropsko gospodarsko pravo $\cdot$ Slovenija $\bullet$ znanstvene monografije $\bullet$

\footnotetext{
NASlOv uREDNICE: Vesna Rijavec, Univerza v Mariboru, Pravna fakulteta, Maribor, Slovenija, epošta: vesna.rijavec@um.si.
} 


\title{
Corporate Entities at the Market and European Dimensions 2018
}

\author{
VESNA RIJAVEC
}

\begin{abstract}
The book with the title Corporate Entities at the Market and European Dimensions 2018 is a scientific monograph by several authors of individual chapters. The authors analyzed the legal positions in relation to smart contracts, controlled company and legal protection of shareholders and creditors, the effect of spatial planning and construction legislation into property law, media law and data protection under the General Data Protection Regulation (GDPR) etc. The book contains contributions from the field of public and private law. Individual authors clearly express their views, the difference between the summaries and their own views is clear. The authors are discussing with the power of the arguments with the views in legal theory and jurisprudence, which increases the practical value of the monograph. The book represents a contribution to the development of legal science.
\end{abstract}

Keywords: • company law $\bullet$ commercial contract law $\bullet$ tax law $\bullet$ labor law • insolvency law • enforcement law • European commercial law $\bullet$ Slovenia $\bullet$ scientific monographs •

CORRESPONDENCE ADDRESS: Vesna Rijavec, University of Maribor, Faculty of Law, Maribor, Slovenia, e-mail: vesna.rijavec@um.si. 


\section{Kazalo / Table of Contents}

Predgovor - beseda recenzenta

Foreword - the Word of the Reviewer

Borut Holcman

Tehnologije veriženja blokov in pametnih pogodb

Blockchain and Smart Contract Technologies

Boštjan Kežmah

Poročilo o odvisnosti kot instrument varovanja delničarjev in upnikov odvisnih družb v koncernu

Dependency report as an instrument of protection of controlled company's shareholders and creditors in corporate group

Gregor Drnovšek

Predstavitev in analiza obresti od davčnih obveznosti po slovenskem Zakonu o davčnem postopku

Presentation and Analysis of Interests on Tax Liabilities under the Slovenian Tax

Procedure Act

Jernej Podlipnik

Prepletanje prostorske in gradbene zakonodaje s stvarnim pravom

Influence of Spatial Planning Legislation and Construction Legislation on Property

Law

Renato Vrenčur

Mediji o podjetništvu

Media on entrepreneurship

Jan Stajnko, Šime Ivanjko in Miha Šepec

Dopustnost medijskega poročanja $\mathrm{v}$ predkazenskem in predhodnem kazenskem postopku

Media Reporting in Pre-trial and Preliminary Criminal Procedures

Miha Šepec

Pravna ureditev prekrškov in administrativnih kazni v gospodarstvu (de lege lata)

Legal Regulation of Minor Offences and Adminstrative Violations in the Economy (de lege lata)

Tičar Bojan in Andreja Primec 
Splošna uredba o varstvu podatkov in vpliv na informacijske 215 tehnologije

General Regulation on Data Protection and Influence on Information Technologies Urška Kežmah 
Gospodarstvo je - zaradi razvoja tehnologij in dojemanja le teh v praksi - skozi njihove pozititivne in negativne posledice podvrženo nenehnim spremembam.

Že tradicionalno je v Portorožu od 17. - 19. maja 2018 potekalo 26. posvetovanje Gospodarski subjekti na trgu. Nekateri od predstavljenih prispevkov so bili izbrani za posebno objavo v pričujoči znanstveni monografiji, ki je izšla več kot leto dni po posvetovanju. Vsi prispevki, objavljeni v tej znanstveni monografiji, so bili ponovno recenzirani kot velja za poglavja $v$ znanstvenih monografijah.

V monografiji so objavljeni prispevki desetih avtorjev, ki z aktualnimi vsebinami nagovarjajo gospodarske subjekte, odvisne od tržnih zakonitosti in delujoče znotraj prava in družbenega obveščanja. Avtorji so v monografiji razvrščeni po vrstnem redu sklopov v okviru posvetovanja. 
Boštjan Kežman (Tehnologije veriženja blogov in pametnih pogodb) v svojem prispevku predstavlja dognanja s področja umetne inteligence $\mathrm{v}$ pogodbenem pravu, ki je zagotovo eden ključnih elementov gospodarstva (pogodbeno pravo), ter skozi analizo predstavlja vpliv "pametnih pogodb na družbo, pravosodni sistem in pravno varstvo ter analizira možnostih reguliranja pametnih pogodb".

Gregor Drnovšek (Poročilo o odvisnosti kot instrument varovanja delničarjev in upnikov odvisnih družb v koncernu) v svojem prispevku analizira poročilo o sestavi poslovodno odvisne družbe, pregled in preverbe poročila s posredovanjem v javnost. Obravnava postopke, kakor so predvideni z ZGD-1.

Jernej Podlipnik (Predstavitev in analiza obresti od davčnih obveznosti po slovenskem Zakonu o davčnem postopku) v svojem prispevku opozarja na davčne postopke zavezancev in hkrati analizira pravila o obrestih. Prispevek ponuja rešitve zakonodajalcu in hkrati opozarja na možnost neustavnosti trenutne ureditve.

Renato Vrenčur (Prepletanje prostorske in gradbene zakonodaje s stvarnim pravom) v svojem prispevku analizira gradbeni zakon in vplive rešitev na urejanje prostora $\mathrm{v}$ konfliktu med ustavo, rešitvami na osnovi sodne prakse Vrhovnega sodišča in oceno Ustavnega sodišča.

Jan Stajnko, Šime Ivanjko, Miha Šepec (Mediji o podjetništvu) v prispevku obravnavajo prakse medijev v odnosu do podjetništva. Poseben del razprave je posvečen "medijskemu sojenju" in družbenim omrežjem v kazenskih postopkih proti lastnikom in poslovodstvu gospodarskih subjektov.

Bojan Tičar, Andreja Primec (Pravna ureditev prekrškov in administrativnih kazni v gospodarstvu (de lege lata) v svojem prispevku predstavljata novelo Zakona o prekrških (ZP-1J), katere namen je "v preventivnem delovanju" in "odvračanju od izvrševanja administrativnih kršitev".

Urška Kežmah (Splošna uredba o varstvu podatkov in vpliv na informacijske tehnologije) v svojem prispevku izpostavlja (predvsem) novosti, ki jih v zvezi z obdelavo osebnih podatkov prinaša Splošna uredba o varstvu osebnih podatkov. 




\title{
Tehnologije veriženja blokov in pametnih pogodb
}

\author{
BOŠTJAN KEŽMAH
}

Povzetek Pametne pogodbe temeljijo na porazdeljenih omrežjih, ki uporabljajo tehnologijo veriženja blokov in za katera se vse pogosteje uporablja splošni izraz porazdeljena glavna knjiga. Bistvena lastnost veriženja blokov je v trajnosti in nespremenljivosti podatkov, ki so shranjeni v glavni knjigi. Prenos sredstev v obliki kovancev, ki ga je uveljavilo omrežje Bitcoin, je najbolj preprosta oblika pametne pogodbe. Študija analizira smiselnost uporabe pametnih pogodb pri uporabi vhodnih podatkov zunaj omrežja verige blokov (oraklji) ter preučuje učinke scenarijev uporabe na realno življenje. $\mathrm{V}$ drugem delu analize $\mathrm{z}$ miselnim eksperimentom raziskuje vpliv pametnih pogodb na družbo, pravosodni sistem in pravno varstvo ter analizira možnosti reguliranja pametnih pogodb. $\mathrm{Na}$ podlagi spoznanj eksperimenta in dokumentiranih izkušenj pri realni uporabi pametnih pogodb in drugih vrst uveljavljenih porazdeljenih omrežij, identificira ključne nerešene izzive pametnih pogodb.

Ključne besede: - veriga blokov - pametna pogodba • porazdeljeno omrežje • decentralizirano omrežje • šifriranje •

NASLOV AVTORJA: Boštjan Kežmah, Univerza v Mariboru, Fakulteta za elektrotehniko, računalništvo in informatiko, Maribor, Slovenija, e-pošta: bostjan.kezmah@um.si. 


\title{
Blockchain and Smart Contract Technologies
}

\author{
BOŠTJAN KEŽMAH
}

\begin{abstract}
Smart contracts are distributed networks based on blockchain technology, lately described using the general term "distributed ledger technology". The essential feature of blockchains is reliable storage and immutability of the data stored in the general ledger. The transfer of coin-operated assets in the Bitcoin network is the simplest form of a smart contract. The study analyzes the relevance of the use of smart contracts when using input data outside of the blockchain network (oracle) and examines the effects of use cases in real life. In the second part of the analysis based on thought experiment, the influence of smart contracts on society, the judicial system and legal protection is observed, and the possibilities of regulating smart contracts are analyzed. Based on the findings of the experiment and documented experiences in realworld use of smart contracts and other types of established distributed networks, we identify key unresolved challenges of smart contracts.
\end{abstract}

Keywords: • blockchain $\bullet$ smart contract $\bullet$ distributed network $\bullet$ decentralized network $\bullet$ encryption •

CORRESPONDENCE ADDRESS: Boštjan Kežmah, University of Maribor, Faculty of Electrical Engineering and Computer Science, Maribor, Slovenija, e-mail: bostjan.kezmah@um.si. 


\section{Uvod}

Tehnologije veriženja blokov so dobile svoje ime zaradi tehnične strukture, na kateri temelji njihovo delovanje, to je verige blokov. Vsak posamezni blok je povezan s prejšnjim na podlagi kriptografske povezave, vsak blok pa vsebuje seznam transakcij. Transakcije ustvarjajo in izmenjujejo enakovredni uporabniki omrežja in s tem spreminjajo stanje verige blokov.

Veriga blokov je decentralizirana, transakcijska podatkovna baza, ki omogoča preverjene, na spremembe odporne transakcije, ki vključujejo veliko število deležnikov (Lynn, Mooney, Rosati, \& Cummins, 2019).

Transakcije lahko predstavljajo izmenjavo vrednosti, vendar niso omejene le na finančne transakcije, temveč lahko omogočajo tudi izvajanje poljubne kode $\mathrm{v}$ tako imenovanih pametnih pogodbah (Wust \& Gervais, 2018).

Pametno pogodbo je definiral Nick Szabo kot pristop, s katerim bi lahko mnoge vrste pogodbenih določil vključili v programsko ali strojno opremo na takšen način, da bi imela kršitev pogodbe za kršitelja visoko ceno in kadar je to zaželeno celo nedoseglijo (Szabo, 1996).

Kot najširši pomen ideje si je Szabo predstavljal, da bi morale biti pogodbe »vključene v svet« (Szabo, 1996) v smislu, da postanejo nedeljiv del naše predstave sveta, kot npr. zakoni fizike. Pri tem bi morali biti mehanizmi sveta strukturirani na takšen način, da bi bile pogodbe (Szabo, 1996).

a) odporne na preprost vandalizem in

b) odporne na napredne, motivirane kršitve.

Pametna pogodba je torej poseben protokol, ki je namenjen prispevanju, preverjanju ali izvedbi pogajanj ali pogodbe. Pametne pogodbe omogočajo izvajanje kredibilnih transakcij brez sodelovanja tretjih strank. Te transakcije so sledljive in niso reverzibilne. Vsebujejo vse informacije glede pogodbenih pogojev ter samodejno izvedejo vse zastavljene aktivnosti (Tar Andrew, 2017). 
Tudi omrežje Bitcoin, najbolj prepoznavno zaradi ekonomskega balona $\mathrm{v}$ drugi polovici leta 2017, temelji na primitivni pametni pogodbi. Pogodba je v tem primeru lahko primitivna zato, ker so vsi podatki, ki jih potrebuje za svoje delovanje, shranjeni v verigi blokov in poenostavljeno vsebuje: naslov pošiljatelja, naslov prejemnika in število enot prenosa sredstev (žetonov, $\mathrm{v}$ tem primeru kriptografskih žetonov bitcoin). Pametna pogodba v omrežju Bitcoin primarno preverja le ali je vsota sredstev, ki bodo nakazana iz enega ali več naslovov, enaka vsoti sredstev, ki bodo pripisana drugim naslovom. S tem omrežje zagotavlja, da izvajalci transakcij ne morejo ustvariti novih žetonov samo s transakcijo in s tem preprečujejo goljufije, povezane z ustvarjanjem novih sredstev (žetonov), torej njihovo ponarejanje.

Že nekateri pravni strokovnjaki ugotavljajo, da pametne pogodbe segajo bistveno izven obstoječih modelov sklepanja pogodb in predstavljajo novo paradigmo interakcije v kibernetskem prostoru (Savelyev, 2017).

Kot bomo predstavili $\mathrm{v}$ nadaljevanju, se $\mathrm{v}$ primerih, ko želimo s pametnimi pogodbami urejati poslovne odnose izven primitivnega scenarija prenosa sredstev, srečamo z mnogimi izzivi, ki jih ni le težko premostiti, temveč izzivajo tudi dodano vrednost verige blokov. Hkrati pa pametne pogodbe predstavljajo temelj za oblikovanje avtonomne, samo-regulirane kibernetske družbe.

\section{Svet pametnih pogodb}

Szabo je svet pametnih pogodb definiral, ko še ni obstajalo primerno tehnično okolje, $\mathrm{v}$ katerem bi se lahko izvajale.

Pametna pogodba, ki se izvaja v verigi blokov, ima skladno z definicijo, ki jo je postavil Szabo, naslednje značilnosti:

- deluje z visoko verjetnostjo razpoložljivosti,

- ni možnosti cenzure,

- ni možnosti goljufij,

- ni možnosti vmešavanja tretjih strank.

Tudi $\mathrm{v}$ pravnih razpravah zasledimo definicijo, da je pametna pogodba le tista pogodba, ki ima naravo samo-izvršitve (Savelyev, 2017). 
$\mathrm{V}$ trenutnem stanju tehnike se odražajo v obliki tehnologij, ki jih imenujemo tehnologija porazdeljene glavne knjige (angl. »distributed ledger technology DLT«). Za te tehnologije je značilno, da so podatki in pravila odločanja razpršeni, ponovljeni ter usklajeni med množico vozlišč, ki si med seboj ne zaupajo in praviloma predstavljajo veliko število posameznikov, interesnih skupin ali institucij.

Prvi in najbolj razširjen svet pametnih pogodb je omrežje Bitcoin, ki ga je izumil posameznik ali skupina s psevdonimom »Satoshi Nakamoto« (Nakamoto, 2008)1 v letu 2008. Obljubljalo je predvsem zmanjšanje stroškov in pohitritev prenosov sredstev med računi (Bitcoin naslovi) s tem, da bi iz poslovanja izvrševanja pogodb izločilo banke. Nakazila med naslovi so izjemno poenostavljen, primitiven primer pametne pogodbe, kjer uporabnik, ki želi nakazati sredstva, dokaže, da je lastnik naslova, zato mu omrežje dovoli, da na drugi naslov nakaže določeno število enot valute (Bitcoin). Pri tem svet pametnih pogodb (omrežje Bitcoin) izvaja oziroma preverja pogodbena določila tako, da preverja ali je na izvornem računu dovolj sredstev, da je zahtevano število enot valute mogoče pripisati drugemu naslovu in hkrati preverja, da se ob prenosu sredstev ne bi ustvarile nove vrednosti valute, kar preprosto preveri tako, da mora biti za vsako transakcijo vsota »dvigov« sredstev enaka vsoti »pologov« sredstev. Če sta vsoti enaki, potem je svet pametnih pogodb prepričan oziroma je zagotovil, da s transakcijo ne bodo ustvarjena nova sredstva.

Nova sredstva lahko ustvarijo le rudarji, ki so z ustvarjenimi novimi sredstvi nagrajeni za svoje delo. Njihovo delo je preverjanje določil pogodbe, kar opravijo tako, da izvajajo algoritme, ki jih določa omrežje, s svojimi viri (računalniško opremo, električno energijo, internetno povezavo). Ob tem rešujejo tudi izjemno računsko zahtevno matematično uganko, katere namen je preprečiti vandalizem in motivirane kršitve, ki jih je predvidel Szabo. Ker vnaprej ni mogoče določiti kateri rudar bo prvi rešil uganko, so s tem tudi manipulacije in vplivi na rudarje težje izvedljivi, kar daje omrežju nujno potrebno varnost za sodelovanje med vozlišči, ki si medsebojno ne zaupajo.

\footnotetext{
${ }^{1}$ Psevdonim, prave identitete avtorja ali avtorjev še vedno ne poznamo
} 
Način delovanja omrežja je izrazito asimetričen. Reševanje uganke je računsko zahtevno, medtem ko je preverjanje rešitve uganke preprosto. To omogoča vsem vozliščem, ki sestavljajo omrežje, da se lahko enostavno, brez velikega računskega vložka prepričajo, da je rudar res našel rešitev matematične uganke. Ob tem lahko vozlišča preverijo tudi ostale določbe pogodbe, predvsem ali so res vse transakcije zastavljene tako, da z izvedbo transakcij ne bodo ustvarjene nove enote valute.

Zaradi narave problema (prenos sredstev), imajo vozlišča na razpolago vse informacije, ki so potrebne za preverjanje skladnosti s pogodbo že znotraj vsake posamezne transakcije in zato ne potrebujejo nobenih dodatnih informacij izven omrežja.

Razpoložljivost informacij in enostavnost problema sta vodila k razvoju omrežja (Bitcoin), ki je specializirano izključno za prenos sredstev in zna zato izvajati samo eno vrsto pametne pogodbe.

Omrežje Bitcoin je hkrati predstavnik verige blokov brez pooblastil, ki je odprto in decentralizirano omrežje. Zato ne obstaja centralna entiteta, ki upravlja s člani omrežja in ki bi lahko prepovedala delovanje uporabnikom $\mathrm{v}$ primeru nedovoljenega branja ali pisanja $v$ omrežje. To pomeni, da je vsa vsebina, shranjena v omrežju, dostopna vsem uporabnikom omrežja (Wust \& Gervais, 2018).

\section{$3 \quad$ Problem zaupanja ali problem bizantinskih generalov}

Svet pametnih pogodb primarno rešuje problem zaupanja med strankami, med katerimi ni vzpostavljenega zaupanja in ga zaradi narave poslovanja ali značilnosti strank tudi ni mogoče vzpostaviti.

Tak primer so opisali že Lamport, Shostak in Pease kot problem bizantinskih generalov. V osnovi problem izhaja iz splošnega problema $\mathrm{v}$ računalništvu, zaradi katerega deli informacijskega sistema, ki nepravilno delujejo, sporočajo drugim delom informacijskega sistema napačne, lahko tudi nasprotujoče si podatke. 
Problem so slikovito predstavili kot problem bizantinske vojske, ki oblega mesto. Okrog mesta so nastanjene vojaške enote in generali se morajo uskladiti glede vojaške taktike, pri tem pa komunikacijo zagotavljajo sli. Eden ali več generalov je lahko izdajalcev, ki bodo poskušali vnesti zmedo med ostale. Cilj je poiskati algoritem, ki bo omogočal zvestim generalom, da dosežejo dogovor glede vojaške taktike. Izkaže se, da je pri uporabi ustnih sporočil problem rešljiv samo, če je zvestih vsaj dve tretjini generalov, če pa bi uporabljali pisna sporočila, ki jih ni mogoče ponarediti, je problem rešljiv za katerokoli število generalov in izdajalcev (Lamport, Shostak, \& Pease, 1982).

Verige blokov dosežejo skupni dogovor na podlagi tega spoznanja z uporabo decentralizacije odločanja in javne porazdelitve glavne knjige.

Šele z vzponom Bitcoin omrežja in sorodnih omrežij, ki temelijo na verigah blokov in podobnih tehnologijah, se je kot splošni pojem porazdeljenih, deljenih, med seboj usklajenih digitalnih podatkov, ki so geografsko razpršeni v mnogih mestih, državah ali institucijah in za katere ne obstaja centralna nadzorna enota ali centralna zbirka podatkov, začel uveljavljati izraz porazdeljena glavna knjiga (DLT).

\section{$4 \quad$ Veriženje blokov}

Veriga blokov je veriga med seboj kriptografsko povezanih in zaščitenih zapisov, ki jih imenujemo bloki.

Praviloma vsak blok vsebuje kriptografsko zgostitev (imenovano tudi prstni odtis, zgoščena vrednost) prejšnjega bloka, časovno značko in podatke o transakcijah, ki sestavljajo blok.

\subsection{Zgoščevalne funkcije}

Bistveno vlogo v verigah blokov imajo zgoščevalne funkcije. To so enosmerne matematične funkcije $\mathrm{v}$ obliki algoritmov, ki vhodne podatke preoblikujejo $\mathrm{v}$ izhodne na takšen način, da imajo izhodni podatki vedno enako dolžino. Lahko si jo predstavljamo tudi kot izjemno učinkovito funkcijo za stiskanje podatkov, ki podatke zgosti do te mere, da se pri tem izgubi toliko informacij, da iz izračunanega rezultata ne moremo več povrniti izvornih podatkov (zato jih tudi imenujemo enosmerne funkcije, saj je mogoče opraviti izračun le v eno smer). 
Primer zgoščevalne funkcije, ki se uporablja le za kontrolo pravilnosti podatkov, je kontrolna cifra, ki je zadnja števka davčne številke ali EMŠO in kontrolni števki na koncu številke transakcijskega računa.

Kontrolna številka EMŠO predstavlja 13. števko in se izračuna iz prvih 12 števk. (Uredba o načinu določanja osebne identifikacijske številke, 1999) Skladno s predpisi se pri izračunu kontrolne številke uporabljajo uteži tako, da se prva števka EMŠO pomnoži z utežjo 7, druga števka z utežjo 6 in tako naprej vse do šeste števke, potem se vrednost uteži ponovno poveča na 7 pri sedmi števki in zmanjšuje do uteži 2 pri dvanajsti števki. Rezultati zmnožkov se seštejejo in vsota deli z 11. Ostanek pri deljenju se odšteje od števila 11 in dobljena razlika je kontrolna številka.

Kontrolne števke osebnih identifikatorjev niso le določene po izjemno enostavnih algoritmih, imajo tudi zelo majhno zalogo vrednosti - število kombinacij, ki jih lahko opišejo. Tako na primer pri EMŠO lahko z eno števko opišemo le 10 različnih številk, pri nadaljnjih številkah EMŠO pa se začne kontrolna števka (zgostitev) ponavljati.

Za kriptografske zgoščevalne funkcije zato velja, da imajo dovolj veliko zalogo vrednosti, da je verjetnost, da bi dva podatka imela enako zgostitev, zanemarljivo majhna. Prekrivanju zgostitvene vrednosti, pri kateri imata dva vhodna podatka isto zgostitveno vrednost, pravimo tudi kolizija. Odpornost na kolizije je pomembna lastnost kriptografskih zgoščevalnih algoritmov med drugim tudi zato, ker imajo zgostitve vrednosti bistveno vlogo pri elektronskem podpisovanju in ne želimo, da bi imeli dve pogodbi enak »prstni odtis« oziroma zgostitev, saj bi lahko katerakoli od pogodbenih strank trdila, da je podpisala neko drugo pogodbo (ali podatek), ki ima enako zgostitev kot pogodba, ki je bila dejansko elektronsko podpisana.

Druga kriptografska značilnost je nepredvidljivost zgoščevalne funkcije, ki pomeni, da že izjemno majhna sprememba vhodnih podatkov bistveno spremeni zgostitev. To je pomembno zato, da je matematično izjemno zahtevno poiskati kolizijo, saj je vpliv spremembe vhodnega podatka na zgostitev izjemno težko predvideti. Če to razložimo na primeru elektronsko podpisanih pogodb, je pomembno, da je za pogodbeno stranko, ki bi želela spremeniti pogodbo, postopek ponarejanja prezahteven, saj ne more s preprosto spremembo nekaj črk 
ali številk na enem mestu in odvzemom črk ali številk na drugem mestu sestaviti pogodbe, ki ima enako zgostitev kot pogodba, ki je bila elektronsko podpisana.

\subsection{Matematična uganka ali dokaz opravljenega dela}

$\mathrm{V}$ Bitcoin omrežju matematična uganka temelji na zgoščevalni funkciji (Nakamoto, 2008). Del vsakega bloka je enkratno kriptografsko število (angl. »nonce«). Idejno izvira iz pristopov k omejevanju neželene pošte (Dwork, 1992) ter algoritma Hashcash (Back, 1997). Hashcash algoritem je v omrežju Bitcoin osnova za dokazovanje opravljenega dela, ki ga v verigah blokov imenujemo rudarjenje.

Rudar izračuna zgoščeno vrednost bloka po pravilih za izračun zgostitve bloka, ki med drugim vsebuje tudi zgostitev transakcij, ki sestavljajo blok z uporabo Merklovega drevesa. Sestavni del podatkov, na podlagi katerih rudar izračuna zgostitev, je tudi naključno kriptografsko število.

Rudar najprej izbere naključno kriptografsko število in izračuna zgostitev celotnega bloka podatkov. Njegova naloga je najti takšno kriptografsko število, da bo imela zgostitev določeno število vodilnih ničel. Zaradi enosmernega delovanja zgoščevalnih funkcij ne more preprosto izračunati kriptografskega števila neposredno iz zgoščene vrednosti in mora uporabiti metodo "grobe sile«, kar pomeni, da preizkuša kombinacije eno za drugo, dokler ne najde prave. Dokler ne najde zgoščevalne funkcije s predpisanim številom vodilnih ničel torej izbira naključna kriptografska števila, jih vstavlja $\mathrm{v}$ blok in računa njegovo zgostitveno vrednost vse dotlej, dokler ne najde takšnega kriptografskega števila, ki ob izračunu zgostitvene vrednosti bloka da rezultat, ki se začne s predpisanim številom ničel. Ko je našel ustrezno kriptografsko število, je rešil matematično uganko in s tem potrdil blok. 

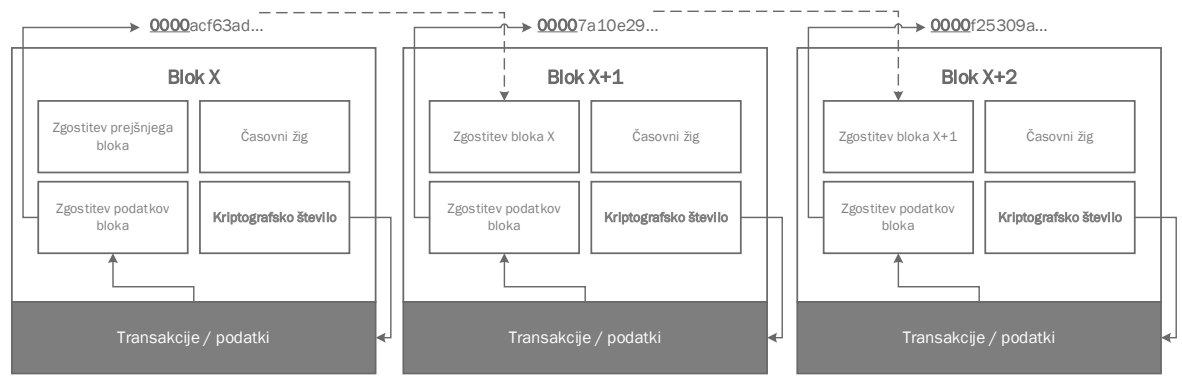

Slika 1: Medsebojna povezanost blokov v verigah blokov

Odvisno od tega kako zmogljivo je omrežje, torej odvisno od tega koliko vozlišč ga sestavlja in kakšne računske kapacitete ta vozlǐ̌ča dosegajo, se s časom hitrost reševanja matematične uganke spreminja. Omrežje doseže stabilnost potrjevanja blokov in s tem varnost delovanja omrežja tako, da spreminja zahtevnost matematične uganke s sprotnim prilagajanjem števila vodilnih ničel v zgoščeni vrednosti. Več kot je vodilnih ničel zgoščene vrednosti, težja je matematična uganka. Tako lahko omrežje dinamično prilagaja zahtevnost rudarjenja. Zahtevnost reševanja uganke se eksponentno povečuje s številom zahtevanih vodilnih ničel. V Bitcoin omrežju se težavnost uganke samodejno prilagaja tako, da rudarji v povprečju rešijo kriptografsko uganko vsakih 10 minut, kar pomeni, da je v povprečju novi blok potrjen v 10 minutah.

Izračun zgostitvene vrednosti se podaljšuje z velikostjo bloka. Večji kot je blok, več časa potrebuje rudar, da izračuna njegovo zgostitveno vrednost. Velikost bloka prav tako vpliva na hitrost posodabljanja blokov v vozliščih omrežja. Večji kot je blok, več časa preteče, preden so vsa vozlišča seznanjena z novim potrjenim blokom.

Iz tega razloga je velikost bloka omejena. V Bitcoin omrežju je velikost bloka omejena na $1 \mathrm{MB}$, kar pomeni, da je glede na količino podatkov za eno transakcijo ter glede na povprečni čas potrditve bloka zmogljivost omrežja tehnično omejena na 7 transakcij na sekundo (Xie, Dai, Chen, \& Wang, 2018).

Dokaz opravljenega dela (angl. "proof of work« - PoW) je le eden od algoritmov za doseganje soglasja $\mathrm{v}$ porazdeljenem omrežju. Njegova poglavitna pomanjkljivost je, da za nekoristno delo porablja veliko količino električne energije. Celotno omrežje namreč za iskanje rešitve matematične uganke porabi veliko količino računske moči, večji del teh kapacitet (izračunov) pa zavrže. 
Nekatere verige blokov ta problem rešujejo z uporabo dokaza deleža (angl. "proof of stake« - PoS), ta pristop pa je povezan s tveganjem, da bi bogati postali še bogatejši (Xie et al., 2018).

\subsection{Dolžina verige}

Uradna veriga je tista, ki je najdaljša. To preprečuje vozliščem, da bi s spremembo in potrjevanjem posameznega bloka lahko spremenile že potrjene bloke. Ker je potrjevanje posameznega bloka računsko zahtevno, bodo v času, ko bi potrjevali ponarejeni blok, v omrežju potrjeni že novi bloki, ki bodo skupaj sestavljali daljšo verigo. Ker bodo vozlišča v omrežju nadaljevala z vzdrževanjem in potrjevanjem najdaljše verige, je potrjevanje ali ponarejanje starih blokov brezpredmetno, saj krajše verige omrežje ne bo uporabljalo kot trenutno veljavne verige blokov, s tem pa tudi ne ponarejenih blokov, ki so v krajši verigi.

Ponarejanje bi bilo mogoče samo v primeru, če bi ponarejevalec obvladoval več kot polovico računske moči celotnega omrežja, saj bi v tem primeru lahko potrjeval bloke hitreje kot preostali del omrežja, kar pa bi moralo biti v praksi dovolj velikega, porazdeljenega omrežja, nemogoče. Tako v praksi najdaljša veriga vključuje največ opravljenega (računskega) dela in ker večino omrežja obvladujejo poštena vozlišča, je najdaljša veriga tudi poštena. (Nakamoto, 2008)

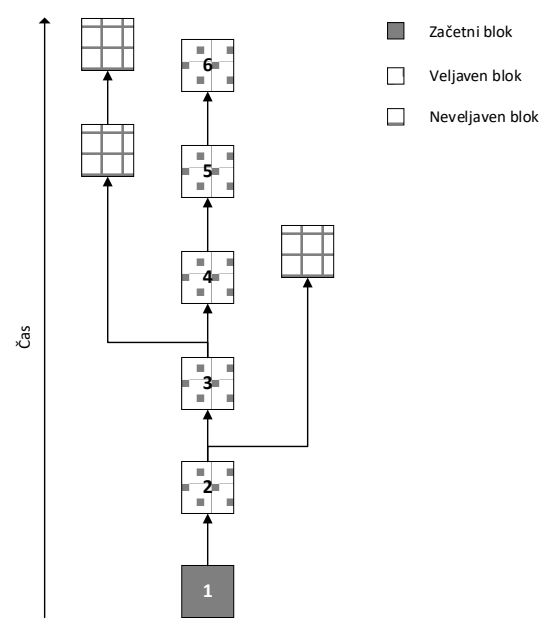

Slika 2: Veljavna je le najdaljša veriga blokov 
Pri tem se je treba zavedati, da algoritem kot bistveni element varnosti uporablja verjetnost. Stopnja varnosti se zato povečuje, kadar se povečuje število rudarjev in zmanjšuje pri upadanju njihovega števila.

V praksi se je tudi izkazalo, da so rudarji pripravljeni sodelovati. Uveljavili so se t.i. »bazeni« rudarjev. Ti temeljijo na skupni storitvi, ki skrbi za razdeljevanje dela med rudarje, ki skupaj rešujejo matematično uganko. Predvsem mali rudarji imajo bistveno manjšo verjetnost, da bodo prvi rešili matematično uganko kot veliki rudarji z veliko računsko močjo. Z združevanjem v bazene lahko veliko število malih rudarjev uspešno konkurira velikim. $Z$ uporabo bazenov se povečuje nevarnost, da bi posamezni bazen rudarjev presegel zmogljivost $50 \%$ omrežja. Rudarji morajo sicer še najti soglasje znotraj svojega bazena, vendar bi s skupnim naporom, za katerega tehnične možnosti obstajajo, lahko bazen vplival na varnost celotnega omrežja.

Ta značilnost lahko predstavlja pomembno omejitev pri dolgoročnem delovanju verig blokov, saj to pomeni, da bi morali uporabniki verige blokov, še posebej tisti, ki imajo $\mathrm{v}$ njej shranjene pomembne informacije, poskrbeti za dolgoročno privlačnost in varnost takšne verige. $Z$ zmanjševanjem privlačnosti se bo pričakovano zmanjševalo število rudarjev, s tem pa varnost informacij. Ker rudarje $\mathrm{v}$ trenutnih modelih najbolj privlači zaslužek, bodo morali dolgoročni uporabniki verig blokov skrbeti za ustrezne inovacije v poslovnih modelih, ki bodo rudarjem omogočale nadaljnje dobičke.

\section{$5 \quad$ Porazdeljena omrežja}

Verige blokov temeljijo na porazdeljenem omrežju. To je bistveno, da lahko zagotovijo, da v omrežju ne nastane ena centralna entiteta, ki ima edina podatke $\mathrm{v}$ posesti. Zaradi zagotavljanja varnosti, ki temelji na verjetnosti, je tudi iz teh razlogov pomembno, da v omrežju sodeluje čim večje število vozlišč. Večje kot je število samostojnih vozlišč, manjša je verjetnost, da bi lahko eno samo vozlišče ali skupina vozlišč ogrozila varno delovanje celotnega omrežja.

Verige blokov niso niti prvo niti edino omrežje, ki temelji na porazdeljevanju podatkov in računskih kapacitet. Eno najbolj razširjenih omrežij je omrežje BitTorrent. To omrežje je najbolj učinkovito predvsem pri deljenju velikih datotek. 
Kljub naporom lastnikov avtorskih pravic in organov pregona zaradi narave delovanja omrežja BitTorrent doslej ni bilo mogoče izključiti, kljub temu, da se $\mathrm{v}$ pomembnem delu uporablja za deljenje nelegalnih vsebin, kot so izmenjava avtorsko zaščitenih vsebin in otroška pornografija (Zhang, Dhungel, Wu, \& Ross, 2011).

Po temeljiti raziskavi BitTorrent omrežja iz leta 2011 za približno 3\% vseh vsebin obstaja več kot 100 enakovrednih vozlišč, ki zagotavljajo isto vsebino (Zhang et al., 2011), kar pomeni, da bi morali za brisanje ene same takšne vsebine doseči izklop več kot 100 računalnikov oziroma strežnikov, ki so lahko geografsko razpršeni po celem svetu, kar je praktično neizvedljivo.

Še en primer uspešnega porazdeljenega omrežja je čebulno usmerjanje (angl. »onion routing«) v omrežju Tor. Je infrastruktura za zasebno komuniciranje v javnem omrežju, ki je odporno na prisluškovanje in analizo prometa (Zhang et al., 2011).

Porazdeljena omrežja zaradi svojih tehničnih značilnosti, ki omogočajo skrivanje identitete in sledi, predstavljajo dobro osnovo za temni splet (angl. »Dark Web«). Tega uporabljajo zlonamerni uporabniki vseh vrst: profesionalni hekerji, pedofili, trgovci z drogami in orožjem, trgovci z belim blagom, teroristi, pirati (Hurlburt, 2017).

Kot odziv na globalno grožnjo temnega spleta podjetja in države vlagajo vse več sredstev v izdelke, storitve in raziskave na tem področju. Že v letu 2004 so ta vlaganja dosegala 3,5 milijarde USD in bodo po pričakovanjih že do leta 2018 dosegla 120 milijard USD letno (Hurlburt, 2017).

Ne glede na vse vložke v raziskave in zaščito doslej temnega spleta ni bilo mogoče izključiti zaradi porazdeljenosti infrastrukture, kar je značilno tudi za Bitcoin in druga porazdeljena omrežja verig blokov.

Prav ta značilna robustnost omrežja in visoka razpoložljivost računskih kapacitet in podatkov predstavlja osnovno infrastrukturo za izvajanje pametnih pogodb. 


\section{Pametne pogodbe}

Bitcoin predstavlja le najbolj preprost primer uporabe pametnih pogodb. Te pridobivajo na uporabnosti $\mathrm{z}$ naraščanjem števila funkcionalnosti, ki jih podpirajo. V omrežju Bitcoin je ta funkcionalnost omejena na preprečevanje nedovoljenega oziroma nenadzorovanega ustvarjanja novih kovancev v omrežju.

Sčasoma sta vzniknili dve različni šoli: Satoshi-jeva šola zagovarja omejevanje števila funkcionalnosti pametne pogodbe (omejevanje funkcionalnosti ukazov) medtem ko šola Vitalika Buterina poudarja prednosti uporabe verige blokov kot računalniške platforme, ki lahko izvaja dobro definirane funkcije s pomočjo pogodb in parametrov (Dhillon, Metcalf, \& Hooper, 2017).

Na podlagi idej šole Vitalika Buterina se je razvilo omrežje Ethereum. Omrežje Ethereum predstavlja Ethereum navidezni stroj (angl. »Ethereum Virtual Machine« - EVM), ki v porazdeljenem omrežju izvaja ukaze, ki predstavljajo pametno pogodbo.

Zaradi značilnosti verige blokov, je pogodba, ko je enkrat objavljena v omrežju, nespremenljiva in nihče od uporabnikov ne more vplivati niti na njeno vsebino, niti na njeno delovanje.

Pogodbe v programskem omrežju Ethereum praviloma nastanejo s pomočjo programskega jezika Solidity.

Primer pogodbe, ki razdeli »dobiček« med določeno število lastnikov, prikazuje slika 3. Evidentno se pisanje pametnih pogodb bistveno razlikuje od pisanja običajnih pogodb, kot jih poznamo danes in zahteva sodelovanje razvijalcev. 


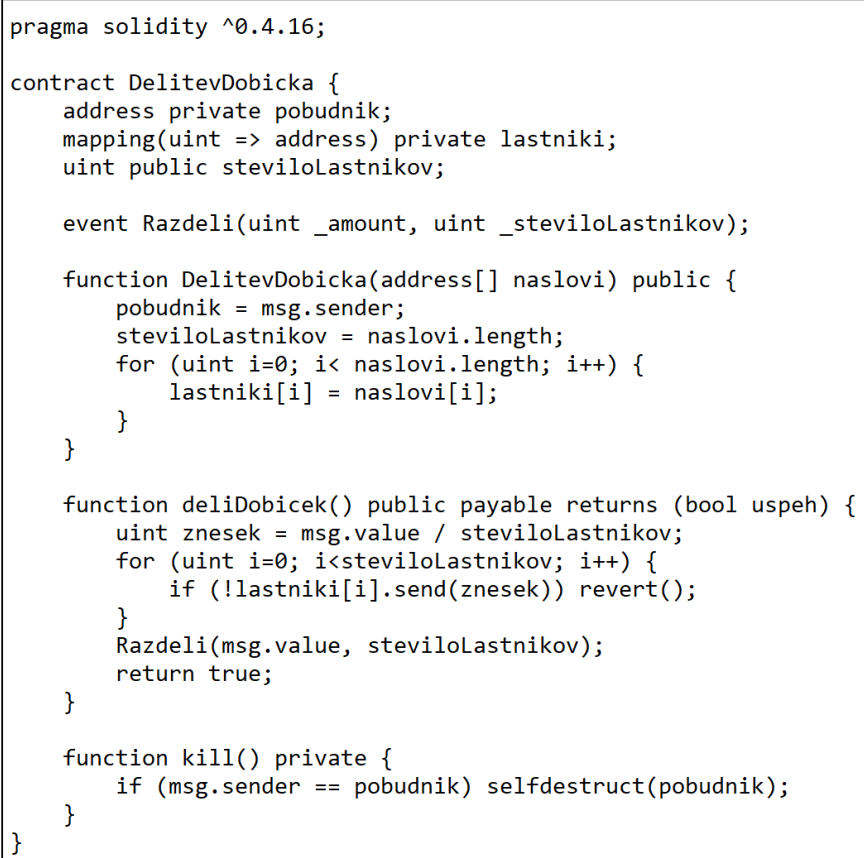

Slika 3: Primer izvorne kode pametne pogodbe v programskem jeziku Solidity

Najpogostejši primeri praktične uporabe pametnih pogodb razen prenosa sredstev oziroma kovancev danes predstavljajo začetne ponudbe kovancev (angl. »Initial Coin Offering - ICO«).

ICO predstavljajo odgovor na zapletene postopke zbiranja kapitala za podjetniške podvige. Izdajanje vrednostnih papirjev nadzirajo zakonodajalci po vsem svetu in pri tem ICO predstavljajo sivo področje »vrednostnih papirjev«, saj spretni izdajatelji kovancev izdajo svojega kovanca organizirajo tako, da ne bi imela značilnosti vrednostnega papirja.

Pomanjkanje nadzora nad izdajo kovancev se odraža v obliki množice novih Ponzijevih shem in drugih oblik goljufij, pri katerih izdajatelji po tem, ko zberejo sredstva, preprosto izginejo (Zongo, 2018). 
Pametna pogodba je torej še vedno le tako poštena, kot so pošteni nameni avtorja pogodbe. Celotnega problema zaupanja v omrežje torej trenutno še ne znamo rešiti samo z uporabo verige blokov. Ko enkrat pogodbene stranke poženejo pogodbo, je zaradi značilnosti porazdeljene infrastrukture in značilnosti verig blokov ni več mogoče niti spremeniti niti ustaviti na zahtevo, ne glede na kasneje odkrite spremenjene okoliščine ali druge vzroke, ki bi v običajnem poslovanju vodili k prekinitvi ali spremembi pogodbe.

\subsection{Praktična uporaba pametnih pogodb}

Glasniki tehnologije verig blokov in pametnih pogodb predstavljajo najrazličnejše scenarije, $v$ katerih so pametne pogodbe boljše od obstoječih, »klasičnih« pogodb.

Primer je pametna pogodba z zavarovalnico. Zavarovanec plača zavarovalno premijo in $s$ tem postane stranka $\mathrm{v}$ sklopu pametne pogodbe. Ko nastopi zavarovalni primer, pametna pogodba zavarovancu samodejno izplača škodo. Pri tem zavarovalnica nima nobenega vpliva na izvajanje pametne pogodbe. Zavarovanec si lahko izvorno kodo (torej pravila) pogodbe sam ogleda v omrežju verig blokov, preden $\mathrm{k}$ taki pogodbi pristopi. Torej je bil natančno informiran o pogojih in načinu izvajanja pogodbe, preden jo je sklenil in je lahko prepričan, da se po sklenitvi pogodbe njena funkcionalnost ne bo spremenila.

Ena pomembnejših omejitev pametne pogodbe je vir podatkov, ki potrdi, da je nastala škoda. Ker si zavarovalnica in zavarovanec ne zaupata, bosta imenovala tretjo, neodvisno osebo, da potrdi oziroma ugotovi, da je škodni dogodek nastal. Pri klasičnih pogodbah je ta zaupanja vredna tretja oseba, ki sprejme dokončno odločitev, sodišče. Če želimo reševanje sporov pri pametnih pogodbah poenostaviti oziroma se jim izogniti, določimo tretjo osebo, ki sporoči samo en podatek in ne preučuje celotne pogodbe. Takemu viru pravimo »orakelj«. Primer bi bil neodvisni strokovnjak, ki spremlja vreme in ugotovi količino padavin na določenem območju, kjer ima nepremičnino zavarovanec. Ob dovolj veliki količini padavin, ki je določena že $\mathrm{v}$ pametni pogodbi, ta samodejno izplača škodo. Ob tem se postavlja vprašanje zakaj ne bi zavarovalnica in zavarovanec takšnega »oraklja« določila že danes, saj ju pri tem nič ne ovira. Če bi bila torej to želja zavarovalnic in zavarovancev, bi lahko enak učinek dosegli tudi brez uporabe pametnih pogodb. 
Velja splošno pravilo, da kadar je predvidena le ena entiteta, ki lahko zapisuje podatke v omrežje (ali jih določa oziroma o njih odloča), veriga blokov ne daje nobene dodatne vrednosti v primerjavi s klasično podatkovno bazo, ki je v tem primeru bolj primerna izbira, še posebej z vidika učinkovitosti njenega delovanja (Casino, Dasaklis, \& Patsakis, 2018).

Podobne primere najdemo tudi v različnih razpravah in literaturi. Primer je bazen sredstev v primeru naravnih nesreč, ki ga sami ustanovijo kmetje v verigi blokov. Ko nastopi škodni dogodek, pametna pogodba sredstva razdeli po vnaprej znanem ključu. Pri tem pametna pogodba zagotavlja visoko raven preglednosti in zmanjšuje tveganja posrednika ter tveganja, povezana s človeškim faktorjem (Savelyev, 2017).

Tako kot $\mathrm{v}$ ostalih podobnih primerih tudi tukaj bistven problem predstavlja orakelj. Kdo je tisti, ki določi, da je nastopil škodni dogodek? Takoj, ko je to človek, se ne moremo izogniti dvomu v njegovo nepristranskost, strokovnost, doslednost, objektivnost ali drugače - vedno bo obstajal sum korupcije.

Če sum korupcije ostaja, ali je to še vedno pametna pogodba? Pametna pogodba bi morala preprečevati goljufije in vmešavanje tretjih oseb. Takoj, ko uporabimo orakelj, postane orakelj tisti, ki je tretja oseba in ki lahko goljufa.

Ker z vmešavanjem tretje osebe (oraklja) niso več izpolnjeni pogoji za pametno pogodbo, potem je vprašljiva tudi uporaba tehnologije veriženja blokov, saj bi lahko enak učinek dosegli tudi z ročnim postopkom ali uveljavljenimi načini informatizacije oziroma avtomatizacije postopkov $-z$ običajno programsko opremo, ki ne zahteva zapletenih šifrirnih postopkov, porazdeljenih omrežij in ne porablja tako velikih količin energije, saj v vsakem primeru postavljamo proces, ki mu ne zaupamo popolnoma in zato ne more delovati $\mathrm{v}$ celoti avtonomno in brez možnosti korektivnih ukrepov.

Definicija škodnega dogodka je lahko tudi zelo zapletena. Kako visoko nad zemljiščem mora biti gladina vode, da šteje kot poplava? Ali mora poplaviti celo kmetijo vsaj enega najmanjšega kmeta? Kaj pa tretjino površin vsakega? Je morda dovolj že polovica kmetije največjega kmeta? 
Tudi razdelitev sredstev je lahko zapletena. Ali dobijo izplačano škodo vsi kmetje ali samo tisti, ki je škodo dejansko utrpel? Ali dobi izplačan svoj celotni delež sredstev ali samo glede na stopnjo škode, ki mu je nastala (kdo stopnjo ugotavlja - orakelj?)?

Tudi če v primerih zapletenosti izločimo orakelj kot člen, ki s svojim vplivom izniči prednosti verige blokov, se postavi vprašanje ali bodo uporabniki (pogodbene stranke) res sposobni sami sestaviti in zapisati programsko kodo pametne pogodbe, ki vključuje tako veliko število različnih odločitev. Tudi ob predpostavki, da bi nekaj strank imelo dovolj zmogljivosti in znanja, da takšno pogodbo sestavi, ali lahko upravičeno pričakujemo, da bodo manj usposobljene pogodbene stranke sposobne prebrati in v celoti razumeti takšno pogodbo?

\subsection{Vpliv pametnih pogodb na realno življenje}

$\mathrm{V}$ primeru pametnih zavarovalnih pogodb učinki, ki jih povzroči pogodba, vplivajo »samo« na prestavljanje podatkov znotraj omrežja verige blokov, kar pomeni, da zavarovalnica ali zavarovanec $\mathrm{v}$ najslabšem primeru izgubita sredstva iz svojega naslova, na katerem so sredstva shranjena. $\mathrm{V}$ nekaterih primerih pa lahko učinki pametne pogodbe vplivajo na realno življenje in celo fizično varnost posameznikov ter s tem ogrožajo njihovo življenje.

Primer je plačilo najemnine, ki temelji na pametni pogodbi. Pametna pogodba spremlja plačila najemnine in če najemnik najemnine ne plača, izvede samodejno »izvršbo« tako, da zaklene električno ključavnico stanovanja do plačila zaostalih najemnin. Vprašanje je kako $\mathrm{v}$ teh primerih poskrbimo za varnost ljudi. Ker pametna pogodba meri le čas zamude pri plačilu, lahko najemnika kar zaklene v stanovanje (in nato slučajno izbruhne požar) ali pa najemnika zaklene iz stanovanja (ta pa je pred tem na primer majhnega otroka odložil samega $\mathrm{v}$ stanovanje). Tudi iz tega razloga potencialno škodljive transakcije $v$ praksi še vedno izvajamo pod nadzorom pravosodnega sistema. Z izbiro pametne pogodbe se stranke odrekajo pravni varnosti, ki jo zagotavlja pravosodni sistem. Tudi če pravosodni sistem trenutno še lahko odpravi nekatere posledice učinkovanja pametne pogodbe, lahko to izvede šele naknadno, po dogodku, zato ne-reverzibilnih posledic ne more več odpraviti. 
Podoben primer je pametna pogodba, ki skrbi za plačilo obroka leasinga za avtomobil. Če obrok ni bil poravnan pravočasno, pametna pogodba preprosto izključi zaganjač motorja avtomobila in s tem prepreči vozniku, da bi avtomobil ponovno zagnal. To lahko ima neposredne posledice vsaj za lokalni promet in druge udeležence $\mathrm{v}$ prometu (na primer ustavitev avtomobila na prometni cesti $\mathrm{v}$ času prometne konice), lahko pa udeležence v prometu tudi življenjsko ogroža.

Predstavljena primera temeljita na finančnih transakcijah, saj je bistven podatek za izvrševanje pogodbe podatek o (ne)izvršenem plačilu. Za celovito, samodejno delovanje pametnih pogodb, kot je primer ugotavljanja nastopa škodnega dogodka ali poznavanje drugih okoliščin, nujnih za izvrševanje pogodbe (npr. ali bo aktivnost pametne pogodbe ogrozila življenje pogodbenih strank ali celo tretjih oseb), pa v praksi potrebujemo dovolj senzorjev, ki pametne pogodbe oskrbujejo s podatki. Z vsakim dodanim senzorjem je $\mathrm{v}$ pogodbi več odločitev in $\mathrm{z}$ večanjem števila odločitev $\mathrm{v}$ programski opremi se povečuje možnost napak. Ko se povečuje možnost napak, se povečuje interes posameznikov, da imajo neko obliko varstva za primere, ki niso bili predvideni ali za primere, ko pametna pogodba ne deluje skladno s pričakovanji (njihovo voljo). Pri klasičnem poslovanju takšno varstvo zagotavljajo predpisi in sodišča.

Zmogljivost pametnih pogodb bo torej odvisna od vzpona interneta stvari (angl. »Internet of Things« - IoT), saj le v svetu interneta stvari lahko pametne pogodbe dobijo dovolj podatkov, da lahko zaščitijo vse pogodbene stranke. Primer je prodaja rabljenega avtomobila. Veliko podatkov je potrebnih, da je lahko kupec prepričan $\mathrm{v}$ kakšnem stanju je rabljeni avtomobil prodajalca (ali je bil poškodovan, kako in kdaj je bil servisiran, kakšne okvare so bile odpravljene ipd.).

Prav zato bo tudi na področju zavarovalništva prebojni napredek mogoč šele po tem, ko bo najširše uveljavljeno zajemanje masovnih podatkov iz avtomobilov na podlagi telematike, o posameznikih na podlagi uporabe nosljivih naprav, o poslovnih prostorih in gospodinjstvih na podlagi pametnih domov in interneta stvari. (Lynn et al., 2019)

Tudi v primerih finančnih storitev in vrednostnih papirjev, ki niso toliko odvisni od podatkov iz okolja, naletimo na praktične omejitve. Opazujmo primer izdaje obveznic. Izdajatelj se odloči obveznice izdati s pomočjo pametne pogodbe, da bi s tem ponudil vlagateljem zanesljivo jamstvo, da jim bo ob zapadlosti obveznic obljubljena sredstva tudi nakazal. 
Pametna pogodba $v$ tem primeru deluje brez oraklja, saj potrebuje le podatke o vlagateljih (njihovih naslovih v omrežju), njihovih vložkih in trenutnem času. Vse te podatke lahko omrežje zbira brez uporabe zunanjih senzorjev tako dolgo, dokler se tudi celotna prodaja obveznic izvaja $\mathrm{v}$ pametni pogodbi $\mathrm{v}$ isti verigi blokov.

Težave tega jamstva predstavlja dejstvo, da lahko pametna pogodba upravlja le s tistimi podatki, ki so v določenem trenutku na razpolago v omrežju. To pomeni, da so ji na razpolago le tista sredstva, ki so v času izplačila shranjena na naslovih izdajatelja obveznic. Da bi lahko v celoti zagotovili jamstvo, ki naj bi ga dajala pametna pogodba za izdajo obveznic, imamo dve možnosti:

1. Pametna pogodba vsa sredstva, ki jih je prejela ob prodaji obveznic, "zamrzne« oziroma zadrži na primer tako, da ima pooblastila za upravljanje s sredstvi na naslovu, kamor shranjuje prejeta sredstva ob prodaji obveznic, samo pametna pogodba. To pomeni, da izdajatelj obveznic ne more do sredstev, ki jih je zbral z izdajo obveznic, vendar je to nujen ukrep, ki pametni pogodbi omogoča, da bo lahko z gotovostjo izplačala sredstva ob zapadlosti. Pri tem bo morala pametna pogodba že ob prodaji obveznic rezervirati še dodatna sredstva izdajatelja, da bo lahko poravnala še obresti. To pomeni, da bo za izdajatelja pametna pogodba predstavljala le strošek, saj ne bo imel možnosti dostopati do zbranih sredstev.

2. Če pametna pogodba ne rezervira sredstev, ki jih za plačilo potrebuje ob zapadlosti obveznic, potem je edino dodatno jamstvo, ki ga daje pametna pogodba, da se bo ob določenem času sprožil poizkus nakazila sredstev iz nekega naslova (računa) izdajatelja na naslove (račune) vlagateljev. Če sredstev na naslovu izdajatelja ne bo dovolj, potem vlagatelji ne bodo prejeli obljubljenih sredstev.

Izdaja obveznic v obliki pametnih pogodb ima zato lahko le dva učinka. Ali je nesmiselna za izdajatelja, ker ta ne more do zbranih sredstev ali pa je nesmiselna za vlagatelje, saj jim pametna pogodba ne zagotavlja pričakovanega jamstva $\mathrm{v}$ zvezi z izplačilom in je zato uporaba pametne pogodbe prav tako nesmiselna. 


\subsection{Pametne pogodbe in pravno varstvo}

V praksi se izkaže, da ima tudi nespremenljivost verige blokov svojo mejo. Razen manj verjetne možnosti, da bi napadalec obvladoval več kot polovico računskih kapacitet omrežja, obstaja tudi možnost, da uporabniki z glasovanjem zavestno spremenijo podatke $\mathrm{v}$ blokih.

Primer je zloraba pametne pogodbe v sklopu projekta »Decentralized Autonomous Organization«, ki je bila posledica napake v programski kodi pametne pogodbe. V maju 2016 so se zato uporabniki (celotnega) omrežja Ethereum z glasovanjem odločili, da spremenijo način delovanja omrežja in hkrati »izbrišejo« krajo kovancev (Zongo, 2018). Takšen poseg se imenuje trdi razcep (angl. »hard fork«). Uporaba trdega razcepa se sploh ne bi smela uporabljati, saj je s tem kršeno osnovno načelo nespremenljivosti pametnih pogodb. Če omrežje dovoli trdi razcep, potem ni nobene dodane vrednosti v uporabi verige blokov, saj bi lahko enake učinke dosegli tudi $\mathrm{z}$ obstoječo programsko opremo. Uporaba verige blokov $\mathrm{v}$ takih primerih ne zagotavlja bistvenega dodatnega jamstva, ki bi upravičilo njeno uporabo.

V primeru individualnih zapletov manjše vrednosti je malo verjetno, da bodo pripravljeni vsi uporabniki omrežja lokalno težavo reševati z glasovanjem za trdi razcep. Pogodbene stranke bodo zato morale iskati druge mehanizme za rešitev spora, ob tem pa še razrešiti vprašanje kdo je odgovoren za vsebino pogodbe odvetnik, ki jo je sestavil v obliki besedila ali razvijalec, ki je to besedilo prepisal v programsko kodo pametne pogodbe? Morda pa kar pogodbene stranke, saj so imele možnost pogodbo same prebrati pred njenim podpisom?

Odgovornost in soglasje volje pri sklepanju pogodbe ni edini izziv pametnih pogodb. Sodišča vsaj trenutno še niso opremljena s tehnologijo in znanjem, ki bi sodišču omogočila, da tolmači pametne pogodbe. Zelo verjetno bi sodišče moralo pritegniti sodnega izvedenca $z$ nalogo, da razloži delovanje pametne pogodbe. To pa bi dejansko pomenilo, da sodni izvedenec prevaja pogodbo iz programske kode $v$ naravni jezik. Ob tem je treba izpostaviti, da je prevajanje iz programske kode $\mathrm{v}$ naravni jezik bistveno bolj zahtevno kot prevajanje iz enega naravnega jezika v drugega, saj lahko pričakujemo, da je dele programske kode mogoče opisati z mnogimi različnimi besednimi zvezami $\mathrm{v}$ naravnem jeziku. Torej ne gre le za "preprosto« prevajanje iz enega v drugi jezik temveč za opisovanje programske kode $\mathrm{v}$ naravnem jeziku. 
Med avtorji se pojavlja nova skovanka, »lex kriptografija«, ki se nanaša na novo področje prava - pravila, ki so določena administrativno s samo-izvedbenimi pametnimi pogodbami in decentraliziranimi avtonomnimi organizacijami. Ta bi se naj ukvarjala z vprašanjem kako lahko centralizirana oblast, kot je na primer država in velika multinacionalka, oblikuje aktivnosti razpršenih posameznikov z uporabo obstoječih mehanizmov (Wright \& De Filippi, 2015).

Na podlagi koordinacije in zaupanja, ki ga zagotavlja veriga blokov, je mogoče zaobiti neuspešne rešitve obstoječega upravljanja in potencialno rešiti mnoge skupne težave glede transparentnosti in korupcije, ki je sestavni del sprejemanja odločitev vsake organizacije (Wright \& De Filippi, 2015). V pravnih razpravah lahko zato zasledimo, da za izvrševanje pametnih pogodb instrument izvršbe sploh ni potreben (Savelyev, 2017).

Hkrati avtorji opozarjajo, da čeprav je teoretično mogoče vključiti osnovna varovala glede zaščite potrošnikov $\mathrm{v}$ pametne pogodbe, je to lahko težko izvedljivo, če upoštevamo formalizirano in deterministično naravo programske kode. Sčasoma bo široka uporaba pametnih pogodb in drugih kriptografsko aktiviranih virov sprožila množico pomembnih izzivov za trenutno pravno ureditev, vendar je in bo ostala tehnologija, ki jo je mogoče regulirati (Wright \& De Filippi, 2015).

Menimo, da so pričakovanja po zmožnosti reguliranja porazdeljenih omrežij za izvajanje pametnih pogodb neutemeljena, kar dokazujemo v nadaljevanju.

\subsection{Miselni eksperiment}

Predpostavimo, da so izpolnjeni vsi pogoji za sklenitev pametne pogodbe $\mathrm{v}$ porazdeljeni verigi blokov. Pogodbenim strankam je zagotovljena tehnična funkcionalnost za sklenitev pogodbe $\mathrm{z}$ vhodnimi podatki in rezultati pogodbe, ki zadostuje, da vse stranke jasno izrazijo svojo voljo.

Pogodbene stranke sestavijo pametno pogodbo, vsaka od strank pogodbo elektronsko podpiše in s tem sproži izvajanje pametne pogodbe.

Izpolnjeni naj bodo vsi predpogoji za tehnično in varno delovanje pametne pogodbe. 
Pametna pogodba je nespremenljiva, ker v omrežju sodeluje tako veliko število neodvisnih vozlišč, da je verjetnost, da bi lahko posamezno vozlišče ali organizirana skupina vozlišč vplivala na njeno vsebino, zanemarljivo majhna. S tehničnimi ukrepi je pametna pogodba zaščitena tako, da bi vsako spremembo $\mathrm{v}$ pametni pogodbi lahko zaznali (spremenila bi se zgostitvena vrednost bloka, v katerem je shranjena pogodba).

Izvajanja pametne pogodbe ni mogoče ustaviti. Ker se pogodba izvaja na velikem številu neodvisnih vozlišč, ki so geografsko razpršena, je verjetnost, da bi lahko posameznik, organizirana skupina vozlišč ali celo država s svojimi organi in institucijami kakorkoli vplivala na izvajanje pametne pogodbe, zanemarljivo majhna.

Pogodba se bo izvedla točno po navodilih, ki so bila določena ob zagonu pogodbe. Ker pogodba ni spremenljiva in ker njenega izvajanja ni mogoče ustaviti, je edino preostalo tveganje, da se navodila ne bodo izvedla tako, kot so bila določena. Zato naj celotno omrežje (torej programska oprema posameznih vozlišč) temelji na odprtokodni programski opremi, zato predpostavimo, da programska oprema nima stranskih vrat, ki bi omogočala vplivanje na delovanje omrežja ali napak, ki bi lahko vplivala na to, da se pametna pogodba ne bi izvedla skladno z navodili.

Vsi podatki pametne pogodbe so shranjeni $\mathrm{v}$ verigi blokov in le pametna pogodba ima pooblastila za dostop do bistvenih podatkov za izvedbo pogodbe, torej niti na vhodne niti na izhodne podatke nima vpliva nihče drugi kot pametna pogodba.

Z izpolnjenimi vsemi pogoji za dosledno izpolnitev pogodbe, ki je ni mogoče niti spremeniti, niti ustaviti, niti na njeno izvajanje kakorkoli vplivati, predpostavimo, da pogodbene stranke poženejo pogodbo.

Ko so izpolnjeni pogoji, določeni $\mathrm{v}$ programski kodi pametne pogodbe, ta samodejno izvede transakcije nad podatki, shranjenimi v verigi blokov. 
Predpostavimo, da ne glede na to, da se je pogodba izvedla tehnično pravilno, da ni bila spremenjena in da nanjo ni bilo nobenega zunanjega vpliva, med pogodbenimi strankami nastane spor v zvezi s pogodbo. Zaradi poenostavitve eksperimenta ne obravnavamo razlogov in okoliščin kot predpogoj, da je spor sploh možen.

Ker stranke ne morejo doseči soglasja glede spora, se ena od strank odloči, da poseže po pravnem varstvu, zato na sodišču vloži tožbo.

Predpostavimo, da je sodišče tehnično ustrezno opremljeno in ima ustrezno znanje, da lahko pregleda pametno pogodbo in tehnične okoliščine, povezane z njenim izvajanjem. Sodišče lahko torej zadevo obravnava in razsodi.

V sodbi sodišče ugotovi, da ena stranka drugi dolguje še eno transakcijo znane vrednosti, da bo pogodba $\mathrm{v}$ celoti izpolnjena.

Stranka, ki bi morala izvesti dodatno transakcijo, se s sodbo ne strinja in transakcije ne izvede.

Preučimo možnosti, ki jih ima sodišče, da zagotovi, da bo sodba izvršena. V fizičnem svetu bi sodišče prisililo stranko $\mathrm{v}$ izvršitev transakcije $\mathrm{s}$ pomočjo izvršbe.

Sodišče torej ne more vplivati niti na izvajanje pogodbe (je ne more ustaviti, ker deluje $z$ visoko verjetnostjo razpoložljivosti, niti je ne more cenzurirati) in ne more posegati v delovanje pametne pogodbe (ni možnosti goljufij in vmešavanja tretjih strank). Tega ne more izvesti niti prisilno, s tehničnim posegom izvršitelja, ker tehnologija tega ne omogoča. Edina možnost bi bila, da sodišče prepriča več kot polovico vozlišč v omrežju (ki jih je lahko tudi nekaj milijonov), da glasujejo za spremembo (trdi razcep) in na ta način omrežje izvrši odločitev sodišča.

Problem ni omejen le na pametno pogodbo, ki je bila predmet spora. Celotno omrežje deluje kot množica pametnih pogodb, saj smo ugotovili, da celo primitivne transakcije, kot jih izvaja Bitcoin, delujejo kot pametne pogodbe. To pomeni, da sodišče nima nobenega vpliva na nobene podatke ali pametne pogodbe, ki jih ima posamezni uporabnik v omrežju verig blokov. Do teh podatkov ima dostop in lahko z njimi razpolaga le njihov lastnik (tisti, ki poseduje geslo oziroma ključe za dostop do podatkov). 
S tem prehajamo iz trenutno razširjenega kibernetskega prostora, ki omogoča komuniciranje, druženje in izmenjavo podatkov na daljavo, $\mathrm{v}$ prostor, ki samodejno in dosledno izvršuje dogovore $\mathrm{z}$ uporabo kriptografskih rešitev. Imenujmo ga kriptografski prostor.

Dokler ima stranka še kakršnokoli premoženje $v$ realnem (fizičnem) svetu izven kriptografskega prostora, kot je na primer banka, lahko sodišče še vedno izvrši svojo odločitev. Več kot je premoženja, ki ga urejajo pametne pogodbe in je shranjeno v verigah blokov, manj premoženja je v realnem (fizičnem) svetu in $\mathrm{s}$ tem so manjše možnosti za izvršbo, s tem pa vse manjše možnosti za kakršnokoli regulacijo ali poseganje $\mathrm{v}$ poslovanje kriptografskega prostora, urejenega $\mathrm{s}$ pametnimi pogodbami.

Če sodišče ne more izvrševati svojih odločitev, potem ne potrebujemo niti mehanizmov za njihovo izvrševanje. Zakaj potem sploh še potrebujemo predpise? In če ne potrebujemo predpisov, zakaj potem potrebujemo strukture in družbo, ki te predpise določa?

S predstavljenim miselnim eksperimentom ovržemo vse teorije, ki iščejo rešitve za reguliranje kriptografskega prostora. Kriptografski prostor bo zaradi tehničnega načina delovanja sprejel samo tiste odločitve, za katere se bo večina vozlišč strinjala, da so zanje koristne. To dokazujejo že razvita porazdeljena omrežja, ki jih želimo regulirati iz različnih razlogov, vendar kljub velikim naporom in sredstvom za njihovo regulacijo doslej nismo našli načina, ki bi to omogočal. Primer sta prej predstavljeni omrežji Bittorent in Tor.

Vozlišča bodo zaganjala le odprtokodno programsko opremo, za katero lahko preverijo, kako programska oprema deluje. Torej niti prikrito podtikanje funkcionalnosti, ki bi omogočala cenzuro ali vpliv tretjih strank (na primer države) ni mogoča.

Prav zato rešitve, ki temelijo na poskusu »super uporabnika« (npr. Savelyev, 2017), namenjenega državnim organom, ki bi imel pooblastila za spreminjanje vsebine verige blokov skladno s predpisi zato, da bo izvršil odločitve državne oblasti, niso izvedljive. 
Vpliv države ali drugega mehanizma na delovanje kriptografskega prostora bo možen le, če bo dovolj vozlišč, ki sestavljajo omrežje, spoznalo predlagano značilnost omrežja kot dodano vrednost. Edini možni vpliv na delovanje kriptografskega prostora bo zato z napori regulatorja, da prepriča večino vozlišč, da je pravno varstvo, ki ga regulator zagotavlja uporabnikom omrežja, za uporabnike koristno.

Tudi iz tega razloga je za obstoječe regulatorje pravzaprav tvegano, da sodelujejo pri prenosu premoženja iz realnega sveta $\mathrm{v}$ kriptografski prostor (kot npr. bančni računi, zavarovanja, zemljiška knjiga, register motornih vozil ipd.), saj s tem sami sebi zmanjšujejo možnosti za izvršbo in prenašajo moč odločanja v avtonomno družbo, ki nastaja v kriptografskem prostoru.

Zato prenos premoženja v verige blokov zmanjšuje možnosti za, kot ga imenuje Sevelyev, »odklopljeno« poseganje v posle (Savelyev, 2017), pri katerem oblast izvršuje pritisk na stranko s poseganjem $\mathrm{v}$ njeno premoženje in njene pravice $\mathrm{v}$ realnem svetu $z$ namenom, da bi takšno stranko prisilila $v$ izvrševanje odločitev oblasti v kriptografskem prostoru.

Pristop z drakonskimi ukrepi, ki prepovedujejo uporabo kriptografskega prostora (Wright \& De Filippi, 2015), bo težko učinkovit. Države doslej niso uspele s pritiskom na ponudnike telekomunikacijskih storitev preprečiti čezmejne uporabe iger na srečo (pregled tehnologij in pristopov za izogibanje cenzuri je izven namena te študije, samo kot primer tehničnega pripomočka za izogibanje cenzuri omenimo navidezna zasebna omrežja - VPN). Tehnologija zmaguje, ker je uporaba šifrirnih tehnologij $v$ porastu in imajo telekomunikacijski operaterji vse manj možnosti vpogleda $\mathrm{v}$ podatke, ki jih uporabniki prenašajo. Brez centralne točke pa je praktično nemogoče izvajati nadzor nad prenosom podatkov. Razen tega sami predlagatelji drakonskih ukrepov ugotavljajo, da bi takšen pristop pomenil veliko zlorabo moči oblasti (Wright \& De Filippi, 2015).

Skladno z ugotovitvami eksperimenta imajo razprave, povezane z dopustnostjo pametnih pogodb, z njihovo uvrstitvijo v pravni sistem (npr. Savelyev, 2017), njihovo regulacijo (na primer za zaščito potrošnikov) zelo omejeno uporabno vrednost. Če se podmnožica kibernetskega prostora odloči, da vzpostavi kriptografski prostor, $\mathrm{v}$ katerem posluje $\mathrm{v}$ celoti avtonomno na podlagi pametnih pogodb, pravo na ta prostor ne bo imelo nobenega vpliva. Tako kot ni bilo mogoče izključiti omrežja Bittorent in kot ni mogoče preprečiti uporabe omrežja 
Bitcoin, ki se je razvil v prvi razširjeni kriptografski prostor, čeprav se uporablja tudi za nedovoljene transakcije, tako ne bo mogoče ustaviti velikega porazdeljenega omrežja za izvajanje pametnih pogodb in tudi ne izvajati cenzure, ki bi zagotavljala, da pogodbe vsebujejo funkcionalnosti oziroma pogoje, ki jih določajo predpisi. Kot razpravlja Savelyev: edini možni odgovor po zakonu je poskus deanonimizacije in pregona posameznikov, ki so bili v realnem svetu vključeni v transakcijo. Pametne pogodbe ne potrebujejo pravnega sistema za svoj obstoj: delujejo lahko brez pravnega okvirja. Predstavljajo tehnološko alternativo celotnemu pravnemu sistemu in so odličen primer upravljanja odnosov $\mathrm{v}$ kibernetskem prostoru - Reidelbergove lex informatike ali Lessigovega »koda je zakon« (Savelyev, 2017).

\subsection{Izzivi pametnih pogodb}

Trenutno enega večjih izzivov za pametne pogodbe predstavljajo oraklji. Kot smo ugotovili, uporaba oraklja povzroči, da pametna pogodba nima več bistvenih značilnosti pametne pogodbe, zato bi lahko procese, ki uporabljajo oraklje, podprli tudi s klasičnimi informacijskimi sistemi.

Oraklje lahko nadomesti internet stvari. Veliko število senzorjev, razpršenih po celotnem planetu, ki zbirajo veliko število različnih podatkov iz okolja. Te podatke sproti sporoča $\mathrm{v}$ verigo blokov, zato so ti podatki nespremenljivi. Z uporabo velikega števila senzorjev lahko omrežje zagotovi varnost verodostojnosti orakljev na podlagi verjetnosti, enako, kot to velja za celotno omrežje verige blokov.

Varnost, ki temelji na verjetnosti, je naslednji pomemben izziv verige blokov, saj mora porazdeljeno omrežje sestavljati dovolj veliko število vozlišč, da mu lahko zaupamo. Rudarji sodelujejo v omrežju zaradi dobičkov, ki jih rudarjenje prinaša. Dolgoročni obstoj omrežij mora zato temeljiti na dolgoročnem nagrajevanju rudarjev. Bitcoin je omejil število kovancev, ki jih je mogoče še ustvariti z rudarjenjem, alternativo za dobičke pa predstavljajo provizije pri transakcijah. Z upadanjem števila transakcij se zmanjšuje število provizij, s tem pa tudi interes rudarjev, ki zapuščajo omrežje, s tem pa se zmanjšuje tudi verjetnostna varnost, na kateri omrežje temelji. 
Ethereum kot mehanizem za ohranjanje rudarjev uporablja gorivo. Izvajanje pogodbe mora nekdo plačati. V primerjavi z omrežjem Bitcoin, ki izvaja preproste transakcije, ki temeljijo na pametni pogodbi, ki je vgrajena kar v samo omrežje, so lahko poljubne pametne pogodbe, ki jih je mogoče izvajati v omrežju Ethereum tudi poljubno zapletene. Ker je poraba računske moči rudarja odvisna od zapletenosti in obsega pogodbe, je nagrada rudarju s tem tehnično povezana tako, da vsaka operacija, ki jo v sklopu pametne pogodbe izvede rudar, porabi nekaj goriva, ki ga prejme rudar. Hkrati je omejena količina goriva tudi varovalka za to, da v omrežju ne bi obstajale pametne pogodbe, ki se nikoli ne končajo. Vsaka pametna pogodba se konča najkasneje takrat, ko ji zmanjka goriva in s tem je $\mathrm{v}$ omrežju rešen tudi problem ustavljanja $\mathrm{v}$ Turingovih strojih, saj bi bilo omrežje brez tega varnostnega mehanizma izpostavljeno tveganju, da bi škodljiva pametna pogodba ali pametna pogodba z napako lahko potrošila vse vire omrežja in $\mathrm{s}$ tem ustavila njegovo delovanje.

Ob zagonu pogodbe je zato treba določiti največjo količino goriva, ki ga lahko pogodba porabi in če tega zmanjka, potem se izvajanje pogodbe ustavi, podatki pa se vrnejo v začetno stanje. Te »določbe« v pogodbi oziroma takšnega načina njenega obnašanja ni mogoče preprečiti, ker to omejitev tehnično vsiljuje omrežje. Pogodbene stranke torej kljub vsem varovalom ne morejo biti prepričane, da se bo pogodba v celoti dejansko tudi izvedla.

S tem je v praksi kršeno pravilo razpoložljivosti. Omrežje je sicer razpoložljivo, dejansko pa ni nujno, da je razpoložljiva pogodba oziroma se njeno izvajanje $\mathrm{v}$ omrežju lahko ustavi. Posledica tega je, da glede na trenutne tehnične rešitve pogodbene stranke nimajo vseh jamstev, ki bi jih naj zagotavljale pametne pogodbe.

Ker je varnost omrežja občutljiva na njegovo velikost, se pogodbene stranke pri pogodbah, ki imajo daljšo ročnost izvajanja (na primer 5 ali 10 let) soočajo $s$ tveganjem trajnosti omrežja. Z napredovanjem tehnike je zelo verjetno, da se bodo v prihodnosti razvila nova omrežja, kamor se bodo rudarji selili zato, ker bodo prinašala večje dobičke in pri tem ni nujno, da bodo nova omrežja v svoje novo okolje prečrpala vse obstoječe pametne pogodbe. Razen tega lahko zaradi interesa večjega števila vozlišč nastanejo trdi razcepi, zaradi katerih postaja izvirno omrežje vse manjše, dokler ne zadošča več minimalnim kriterijem verjetnostne varnosti. Tudi »minimalni kriterij verjetnostne varnosti« v praksi še ni jasno določen. Nakamoto je $\mathrm{v}$ svojem članku temeljil verjetnostno varnost na 
Poissonovi distribuciji. (Nakamoto, 2008) V Bitcoin omrežju zato velja splošno pravilo, da mora biti potrjenih še 6 naknadnih blokov, da lahko obravnavamo blok kot potrjen. To pa še ne zadostuje za zagotovitev varnosti celotnega omrežja, v katerem je pomembno predvsem koliko uporabnikov nadzoruje kakšen delež vozlišč oziroma računskih kapacitet. Manjši kot je delež uporabnikov, ki nadzorujejo pomemben obseg kapacitet, večja je varnost omrežja. V praksi ni vedno mogoče enostavno ugotoviti katere računske kapacitete so pod nadzorom posameznega uporabnika, kar zaplete ugotavljanje zadostne verjetnosti varnosti omrežja.

Prag doseganja verjetnostne varnosti omejuje uporabnost omrežja Bitcoin. V praksi bi pri poslovanju s kovanci Bitcoin prejemnik plačila moral počakati še na potrditev 6 blokov, da lahko polno zaupa bloku, v katerem je zapisana transakcija, s katero je prejel sredstva. Ob upoštevanju, da Bitcoin omrežje prilagaja težavnost matematične uganke tako, da je blok potrjen v povprečju vsakih 10 minut, to pomeni, da je transakcija lahko dokončno potrjena najhitreje v 60 minutah. Prikazano na praktičnem primeru to pomeni, da bi gost moral počakati še vsaj eno uro po tem, ko je plačal kavo, da bi natakar lahko dovolj zanesljivo potrdil plačilo. Vse to ob predpostavki, da je plačnik ponudil dovolj visoko provizijo za izvedbo transakcije, da jo bodo rudarji vključili $\mathrm{v}$ prvi naslednji blok, ki ga potrjujejo, v nasprotnem primeru pa je temu treba prišteti še čakanje na vključitev transakcije v blok. Ker se transakcije ne vključujejo v bloke po vrsti ampak največkrat po pravilu najvišje obljubljene provizije, plačnik sploh nima jamstva, da bo njegova transakcija $\mathrm{v}$ končnem času uvrščena $\mathrm{v}$ blok in $\mathrm{s}$ tem potrjena.

Z izzivi se srečujejo tudi zakonodajalci, saj s prehodom v kriptografski prostor izgubljajo nadzor nad posli, ki jih sklepajo uporabniki omrežja. Ker so pogodbe nespremenljive, se represivni organi ne morejo vključiti v izvajanje posamezne pametne pogodbe, prav tako pa zaradi izrazite porazdeljenosti ne morejo preprečiti obstoja omrežja, v katerem se pametne pogodbe izvajajo.

Z globalnega vidika pa je uporaba kriptografskega prostora vprašljiva še $z$ vidika učinkovitosti, še posebej $\mathrm{v}$ javnih verigah blokov. Rudarjenje je povezano $\mathrm{z}$ izgubo virov, zato bo za trajnostno uporabo verig blokov treba najti rešitev za zmanjšanje porabe električne energije in poiskati način, kako računsko moč uporabiti za koristno obdelavo podatkov (Casino, Dasaklis, \& Patsakis, 2018). 


\section{$7 \quad$ Sklep}

Pametne pogodbe predstavljajo zanimivo orodje, ki omogoča, da se pogodbene stranke popolnoma arbitrarno odločijo o njihovi vsebini in so pri tem prepričane, da se bo pogodba zanesljivo izvedla točno tako, kot je določeno $v$ njeni nespremenljivi programski kodi.

Pred njihovo uporabo je smiselno preučiti omejitve in pasti, ki izhajajo iz načina njihovega delovanja. Razen omejitev, ki jih vsiljujeta tehnologija in omrežje, kot je možnost napak $\mathrm{v}$ programski kodi pametne pogodbe ali celo programski kodi omrežja, v katerem se izvaja, omejitev pri zagotavljanju, da se bo pogodba tudi dejansko izvedla v celoti, omejitev pri zagotavljanju nespremenljivosti podatkov $\mathrm{v}$ omrežju, varnosti, ki temelji na verjetnosti ter problemih vzpostavitve »orakljev«, zaradi katerih smotrnost uporabe pametne pogodbe postane vprašljiva, se pogodbene stranke srečujejo tudi z vprašanjem pravne varnosti.

$\mathrm{Z}$ uporabo pametne pogodbe se pogodbene stranke pravnemu varstvu odpovedujejo. Danes je sicer še mogoče na podlagi sodbe sodišča izvršiti sodno odločbo v realnem svetu, $\mathrm{z}$ vse bolj celovitim prehodom v kriptografsko družbo pa so možnosti vse manjše. Če bi vse premoženje uporabnikov omrežja obstajalo le v porazdeljenem omrežju verige blokov, izvršba ne bi bila več izvedljiva, saj tretja stranka brez tega, da doseže trdi razcep ne more vplivati na delovanje omrežja, s tem pa bi se postavilo tudi vprašanje smiselnosti sodišč, posledično predpisov, kar bi lahko vodilo do povsem novih oblik družbene ureditve.

\section{Opomba}

Raziskovalni program št. P2-0057 je sofinancirala Javna agencija za raziskovalno dejavnost Republike Slovenije iz državnega proračuna.

\section{Pravni viri}

Uredba o načinu določanja osebne identifikacijske številke, Uradni list RS 645 (1999), pridobljeno iz: https://www.uradni-list.si/glasilo-uradni-listrs/vsebina?urlid=19998\&stevilka $=345$

\section{Literatura}

Back, A. (1997) A partial hash collision based postage scheme, pridobljeno iz: http://www.hashcash.org/papers/announce.txt (April 29, 2018). 
Casino, F., Dasaklis, T. K. \& Patsakis, C. (2018) A systematic literature review of blockchain-based applications: Current status, classification and open issues, Telematics and Informatics, 36, pp. 55-81, doi: 10.1016/j.tele.2018.11.006.

Dhillon, V., Metcalf, D. \& Hooper, M. (2017) Blockchain enabled applications: understand the blockechain ecosystem and how to make it work for you (Apress), doi: 10.1007/978-1-48423081-3087.

Dwork C. N. M. (1992) Pricing via Processing or Combatting Junk Mail - Abstract, pridobljeno iz: http://www.wisdom.weizmann.ac.il/ naor/PAPERS/pvp_abs.html (April 29, 2018).

Hurlburt, G. (2017) Shining Light on the Dark Web, Computer, 50(4), pp. 100-105, doi: 10.1109/MC.2017.110.

Lamport, L., Shostak, R. \& Pease, M. (1982) The Byzantine Generals Problem, ACM Transactions on Programming Languages and Systems, 4(3), pp. 382-401, doi: 10.1145/357172.357176.

Lynn, T., Mooney, J. G., Rosati, P. \& Cummins, M. (eds.) (2019) Disrupting Finance (Cham: Springer International Publishing), doi: 10.1007/978-3-030-02330-0.

Nakamoto, S. (2008) Bitcoin: A Peer-to-Peer Electronic Cash System, pridobljeno iz: www.bitcoin.org (Februar 5, 2019).

Savelyev, A. (2017) Contract law 2.0: 'Smart' contracts as the beginning of the end of classic contract law, Information \& Communications Technology Law, 26(2), pp. 116134, doi: 10.1080/13600834.2017.1301036.

Szabo, N. (1996) Smart contracts: building blocks for digital markets, EXTROPY: The Journal of Transhumanist Thought, (16).

Tar, A. (2017) Smart Contracts, Explained, pridobljeno iz: https:/ / cointelegraph.com/explained/smart-contracts-explained (29. 4. 2018).

Wright, A. \& De Filippi, P. (2015) Decentralized Blockchain Technology and the Rise of Lex Cryptographia, SSRN Electronic Journal, March 10, 2015, pridobljeno iz: http://doi.org/10.2139/ssrn.2580664 (Februar 5, 2019) .

Wust, K. \& Gervais, A. (2018) Do you Need a Blockchain?, In: 2018 Crypto Valley Conference on Blockchain Technology (CVCBT) (IEEE), doi: 10.1109/CVCBT.2018.00011, pp. 45-54

Xie, Z., Dai, S., Chen, H.-N., \& Wang, X. (2018) Blockchain challenges and opportunities: a survey. International Congress on Big Data (Vol. 14), pridobljeno iz: https://www.henrylab.net/wp-content/uploads/2017/10/blockchain.pdf (Februar 5, 2019) .

Zhang, C., Dhungel, P., Wu, D., \& Ross, K. W. (2011) Unraveling the BitTorrent Ecosystem, IEEE Transactions on Parallel and Distributed Systems, 22(7), 1164-1177. doi: 10.1109/TPDS.2010.123.

Zongo, P. (2018) The Promises and Jeopardies of Blockchain Technology, ISACA Journal, 4, pp. 28-35. 


\title{
Poročilo o odvisnosti kot instrument varovanja delničarjev in upnikov odvisnih družb v koncernu
}

\author{
GREGOR DRNOVŠEK
}

Povzetek Prispevek se osredotoča na obravnavo poročila o odvisnosti v odvisni družbi. Poročilo sestavi poslovodstvo odvisne družbe, njegova obravnava pa se nadaljuje $s$ pregledom in preveritvijo poročila ter konča $z$ omejenim razkritjem njegove vsebine in izsledkov njegove preveritve. Z zakonom predvidena razkritja so namenjena predvsem uresničevanju pravic delničarjev. Izpostavljeno mesto zaseda posebna koncernska revizija. Izpolnjenost formaliziranih predpostavk zanjo je razvidna iz razkritega poročila nadzornega sveta iz 282. člena ZGD-1 in razkritega končnega pojasnila iz petega odstavka 545. člena ZGD1.

Ključne besede: • poročilo o odvisnosti • dejanski koncern • odvisna družba $\bullet$ končno pojasnilo $\bullet$ posebna koncernska revizija •

\footnotetext{
NASlOV AVTORJA: Gregor Drnovšek, Univerze v Mariboru, Pravna fakulteta, Maribor, Slovenija, e-pošta: drnovsek.gregor2@gmail.com.
} 


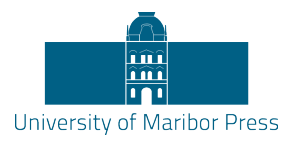

\title{
Dependency report as an instrument of protection of controlled company's shareholders and creditors in corporate group
}

\author{
GREGOR DRNOVŠEK
}

\begin{abstract}
In article the focus is given on the handling of the dependency report on part of the controlled company. The report is prepared by the management of the controlled company, whereupon the report is reviewed and finally the limited disclosure of its content and results of the review is made. The main aim of the disclosures set forth in the law is giving the shareholders access to execution of their rights. The emphasis is placed on the special audit envisaged in the law on the associated companies. Satisfaction of the formalized prerequisites for such audit is evident from the disclosed report of the supervisory board set forth in article 282 of the Companies Act and the disclosed end explication set forth in the fifth paragraph of article 545 of the Companies Act.
\end{abstract}

Keywords: • Dependency report $・$ De facto group $・$ Controlled company $\bullet$ The end explication $\bullet$ Special audit under the law on the associated companies $\bullet$

CORRESPONDENCE ADDRESS: Gregor Drnovšek, University of Maribor, Faculty of Law, Maribor, Slovenija, e-mail: drnovsek.gregor2@gmail.com. 
Zaokrožena celota posebnih pravil o dejanskem koncernu iz 545. do 548. člena ZGD-1 ${ }^{1}$ je zgrajena stopnjevito. Temeljno pravilo je vsebovano $\mathrm{v}$ prvem in drugem odstavku 545. člena ZGD-1 in ga sestavljata dve konstitutivni komponenti, ki zarisujeta ključno vsebino te oblike povezanih družb: (i) prepoved vpliva obvladujoče družbe, ki bi vodil do škodljivih posledic za odvisno družbo (prvi odstavek 545. člena ZGD-1) in (ii) časovno zamaknjena obveznost nadomestiti prikrajšanje odvisni družbi, če obvladujoča družba vendarle škodljivo vpliva na odvisno (prvi in drugi odstavek 545. člena ZGD-1). Drugo komponento kratko imenujemo koncernski privilegij. ${ }^{2}$ Preostale določbe (od tretjega odstavka 545. člena ZGD-1 naprej) pa vsebujejo predvsem mehanizme, ki zagotavljajo spoštovanje temeljnega pravila (iz prvega in drugega odstavka 545. člena ZGD-1), ter urejajo posebne pravne posledice zaradi kršitve temeljnega pravila. ${ }^{3}$ Ta sklop pravil o dejanskem koncernu je bil do zdaj noveliran le enkrat, in sicer z novelo ZGD-1I (78. do 81. člen novele ZGD-1I), ${ }^{4}$ ki pa predstavlja domala pravo reformo slovenskega koncernskega prava. ${ }^{5}$

Prvi mehanizem, urejen s posebnimi pravili o dejanskem koncernu, ki naj bi zagotavljal spoštovanje temeljnega pravila, je poročilo o odvisnosti. ${ }^{6}$ Obveznost sestaviti poročilo o odvisnosti, rok za njeno izpolnitev ter vsebino in omejeno publiciteto poročila urejajo določbe tretjega do petega odstavka 545. člena ZGD1. Potem, ko je sestavljeno, poročilo "potuje« skozi z zakonom predviden instrumentarij, katerega osrednji namen je (i) preveriti poročilo o odvisnosti in s tem spoštovanje temeljnega pravila, in (ii) omejena publiciteta izsledkov te preveritve.

\footnotetext{
${ }^{1}$ Zakon o gospodarskih družbah (ZGD-1), Ur. l. RS, št. 42/06, s poznejšimi spremembami in dopolnitvami.

2 Podrobno o koncernskem privilegiju (Kocbek, 2018: 12-15; Podgorelec, 2018: 41; Podgorelec, 2015: 1124; Podgorelec, 2014:. 63).

3548. člen ZGD-1 vsebuje še nekatere dodatne določbe o odgovornosti organov odvisne družbe, ki se nanašajo na položaj kršitve obveznosti v zvezi s poročilom o odvisnosti.

${ }^{4}$ Zakon o spremembah in dopolnitvah Zakona o gospodarskih družbah (ZGD-1I), Ur. l. RS, št. 55/15.

${ }_{5}$ Podrobno o spremembah in dopolnitvah, ki jih je uvedla novela ZGD-1I v koncernskem pravu (Podgorelec, 2015). Glej tudi (Kocbek, 2017).

${ }^{6}$ ZGD-1 ga imenuje nekoliko različno v različnih določbah, npr. "poročilo o razmerjih s povezanimi družbami« oziroma »poročilo o razmerjih s povezano družbo« (tretji odstavek 545. člena; prvi, tretji in četrti odstavek 546. člena; prvi, drugi in četrti odstavek 546.a člena; prvi odstavek 546.b člena), "poročilo o odnosih do povezanih družb« (naslov 546. člena). V teoriji in praksi se je uveljavil izraz »poročilo o odvisnosti« (Podgorelec, 2014: 75).
} 
V prispevku se bomo osredotočili na to obravnavo poročila o odvisnosti, ki se začne s sestavo poročila s strani poslovodstva odvisne družbe, nadaljuje $s$ pregledom in preveritvijo poročila ter konča $z$ omejenim razkritjem njegove vsebine in izsledkov njegove preveritve. Omejeno razkritje vsebine poročila o odvisnosti ter omejeno razkritje izsledkov njegove preveritve omogočata delničarjem, da se seznanijo z neposrednimi predpostavkami za uresničitev njihove individualne pravice do posebne koncernske revizije iz prvega odstavka 546.b člena ZGD-1.7

\section{Poročilo o odvisnosti}

\subsection{Namen poročila}

Poleg že navedenega namena, ki ga zasleduje poročilo o odvisnosti, to je zagotavljanje spoštovanja temeljnega pravila iz prvega in drugega odstavka 545. člena ZGD-1, ima poročilo o odvisnosti še dva dodatna namena, namreč (i) izboljšati informacijsko podlago za upnike in delničarje (družbenike) ter (ii) nadzornemu svetu in revizorju olajšati pregled relevantnih pravnih in drugih dejanj odvisne družbe (546. in 546.a člen ZGD-1). Te namene uresničuje na sledeč način: ${ }^{8}$

a) Poslovodstvo odvisne družbe ve vnaprej (že pred uresničitvijo posameznega pravnega posla ali drugega dejanja), da bo moralo o relevantnih pravnih poslih oziroma drugih dejanjih poročati $\mathrm{v}$ poročilu $\mathrm{o}$ odvisnosti ter pripraviti posebno pojasnilo iz petega odstavka 545. člena ZGD-1 (tako imenovano »končno pojasnilo«), ${ }^{9}$ ki bo razkrito v poslovnem poročilu. Ta značilnost (funkcija) ima preventivni učinek. ${ }^{10}$

b) Poročilo o odvisnosti je podlaga za revizijo iz 546. člena ZGD-1 in za pregled s strani nadzornega sveta iz 546.a člena ZGD-1.

c) Z razkritjem končnega pojasnila $v$ poslovnem poročilu (peti odstavek 545. člena ZGD-1) in razkritjem izida pregleda s strani nadzornega sveta $\mathrm{v}$

\footnotetext{
${ }^{7}$ Prav tako lajšata uveljavljanje morebitnih odškodninskih zahtevkov. Podrobno o posebni koncernski reviziji (Podgorelec, 2015: 1127-1129). Podrobno o odškodninski odgovornosti v dejanskem koncernu (Podgorelec, 2018; Podgorelec, 2017).

${ }^{8}$ Primerjaj J. Vetter, $\mathrm{v}$ (Schmidt, M. Lutter in drugi, 2015: $\ 312$, robna številka (v nadaljnjem besedilu: r. š.) 12; Podgorelec, 2014: 76; Hüffer \& Koch, 2016: \312, r. š. 1; H.-C. Knoll, v: (Schüppen, B. Schaub in drugi, 2010: $\$ 52$, r. š. 138).

${ }^{9}$ Isti izraz uporablja (Podgorelec, 2014: 77; Podgorelec, 2015: 1127).

${ }^{10}$ Hkrati služi samokontroli poslovodstva odvisne družbe, skupaj z značilnostjo iz naslednje točke b) ter z zakonom predvidenimi razkritji in objavami pa krepi položaj poslovodstva odvisne družbe nasproti obvladujoči družbi.
} 
poročilu (nadzornega sveta) za skupščino (drugi odstavek 546.a člena ZGD1) je delničarjem in upnikom olajšano uveljavljanje odškodninskih zahtevkov iz 547. in 548. člena ZGD-1, prav tako je delničarjem omogočeno uveljavljanje posebne revizije po 546.b členu ZGD-1.

\subsection{Kratko o sestavi in vsebini poročila o odvisnosti}

Poslovodstvo mora poročilo o odvisnosti sestaviti $\mathrm{v}$ prvih treh mesecih poslovnega leta (prvi stavek tretjega odstavka 545. člena ZGD-1). ${ }^{11} \mathrm{~V}$ skladu s četrtim odstavkom 545. člena ZGD-1 mora poročilo o odvisnosti ustrezati načelom vestnosti in verodostojnosti. Gre za generalno klavzulo, ki je vodilo poslovodstvu pri sestavi poročila o odvisnosti in ki poslovodstvo hkrati upravičuje in zavezuje, da sámo ( $z$ ustreznimi navedbami in pojasnili v poročilu), $\mathrm{s}$ ciljem doseči namen, ki ga zasleduje poročilo o odvisnosti, reši vprašanja, ki z zakonom niso izrecno urejena. ${ }^{12}$

Poročilo o odvisnosti mora obsegati "pravne posle« na eni strani in "vsa druga dejanja " na drugi strani. Zakon določa, katere pravne posle in druga dejanja mora zajeti poročilo (drugi stavek tretjega odstavka 545. člena ZGD-1), prav tako določa posamične podatke, ki jih mora poročilo o odvisnosti razkriti o takšnih pravnih poslih in drugih dejanjih (tretji stavek tretjega odstavka 545. člena ZGD1) ter nadomestitvi morebitnega prikrajšanja (četrti stavek tretjega odstavka 545. člena ZGD-1). Poročilo se konča s končnim pojasnilom (peti odstavek 545. člena ZGD-1).

V skladu z drugim stavkom tretjega odstavka 545. člena ZGD-1 se v poročilu o odvisnosti navedejo pravni posli, ki jih je družba sklenila z obvladujočo družbo ali z njo povezano družbo ali na pobudo ali v interesu teh družb. Določba torej razmejuje med tremi skupinami pravnih poslov: (i) pravni posli, ki jih odvisna družba sklene z obvladujočo družbo; (ii) pravni posli, ki jih odvisna družba sklene z družbo, ki je povezana z obvladujočo družbo; (iii) pravni posli, ki jih odvisna družba sklene s tretjimi osebami. Drugače kot pri prvih dveh skupinah pravnih poslov, je za to, da nastane obveznost $\mathrm{v}$ poročilu o odvisnosti navesti pravni posel, ki ga je odvisna družba sklenila s tretjo osebo (tretja skupina pravnih poslov), potrebno, da je bil takšen posel sklenjen na pobudo ali $\mathrm{v}$ interesu

\footnotetext{
${ }^{11}$ Podrobno o obveznosti poslovodstva sestaviti poročilo o odvisnosti in vsebini poročila (Drnovšek, 2018).

12 Primerjaj (Hüffer \& Koch, 2016: \ 312, r. š. 31).
} 
obvladujoče družbe ali z njo povezane družbe. Pojem (vseh) »drugih dejanj« iz drugega stavka tretjega odstavka 545. člena ZGD-1 obsega (vsa) dejanja in opustitve, ki nimajo značilnosti pravnega posla. Pojem »drugih dejanj« je potrebno razumeti kot nadpomenko, ki sicer obsega tudi "pravne posle«, le da pravne posle zakon naslovi kot samostojno vsebino poročila o odvisnosti. Dejanja so namreč lahko tudi pravna dejanja, ena izmed oblik pravnih dejanj, pa je prav pravni posel. ${ }^{13}$ Zato mora poročilo o odvisnosti obsegati tudi opuščene pravne posle (kot opuščena dejanja), čeprav v prvem delu drugega stavka tretjega odstavka 545. člena ZGD-1 (kjer so naslovljeni pravni posli) zakon naslavlja le pozitivno ravnanje (»sklenitev« pravnega posla). ${ }^{14}$ Enako kot pri zgoraj omenjeni tretji skupini pravnih poslov (pravni posli s tretjimi osebami), mora biti tudi pri »drugih dejanjih« izpolnjena posebna predpostavka, zato da nastane obveznost njihove vključitve $\mathrm{v}$ poročilo o odvisnosti: storjena ali opuščena morajo biti na pobudo ali $\mathrm{v}$ interesu obvladujoče družbe ali z njo povezane družbe. V skladu z drugim stavkom tretjega odstavka 545. člena ZGD-1 morajo biti v poročilu o odvisnosti navedeni pravni posli, ki so bili sklenjeni ali opuščeni, in druga dejanja, ki so bila storjena ali opuščena, (obojni) v preteklem poslovnem letu. V skladu s tretjim stavkom tretjega odstavka 545. člena ZGD-1 se pri pravnih poslih navedeta izpolnitev in nasprotna izpolnitev, pri dejanjih pa razlogi zanje, koristi in prikrajšanja za družbo.

Do konca poslovnega leta, $\mathrm{v}$ katerem je bilo odvisni družbi povzročeno prikrajšanje, mora biti to prikrajšanje nadomeščeno ali pa nastati pravni posel, ki ustanavlja obveznost za povrnitev prikrajšanja (prvi in drugi odstavek 545. člena ZGD-1). Zato mora po četrtem stavku tretjega odstavka 545. člena ZGD-1 poročilo o odvisnosti vsebovati podatke o tem, ali so bila prikrajšanja med poslovnim letom dejansko nadomeščena ali pa je bila (do konca poslovnega leta) ustanovljena obveznost $\mathrm{v}$ korist odvisne družbe za nadomestitev prikrajšanja. $\mathrm{V}$ prvem primeru mora poročilo o odvisnosti vsebovati podatke o tem, kako so med poslovnim letom dejansko potekala nadomestila prikrajšanja. $\mathrm{V}$ drugem primeru mora poročilo o odvisnosti vsebovati podatke o tem, do kakšnih koristi je odvisna družba upravičena na podlagi pravnega posla, $s$ katerim je bila ustanovljena obveznost za nadomestitev njenega prikrajšanja.

\footnotetext{
13 Podrobneje o pravnih dejanjih N. Plavšak, v (Plavšak in drugi, 2009, 87-88).

${ }^{14}$ Enak sklep zasledimo tudi v nemški literaturi (za \312 AktG), npr. (Hüffer \&Koch, 2016: \312, r. š. 16).
} 
V skladu s petim odstavkom 545. člena ZGD-1 mora poslovodstvo na koncu poročila o odvisnosti navesti končno pojasnilo. Pri končnem pojasnilu gre za lastno (osebno) oceno poslovodstva, v kateri poslovodstvo strnjeno pojasni, (i) ali je odvisna družba pri pravnih poslih vedno prejela ustrezno nasprotno izpolnitev in pri drugih dejanjih ni bila prikrajšana; in (ii) (če (i) ne drži) ali je bilo prikrajšanje nadomeščeno. Relevanten trenutek za to lastno oceno poslovodstva je (glede na jasno zakonsko besedilo: »... v okoliščinah, ki so ji bile znane v trenutku, ko je bil opravljen pravni posel ali storjeno ali opuščeno dejanje ...«) trenutek oprave oziroma opustitve pravnega posla ali drugega dejanja (peti odstavek 545. člena ZGD-1). Gre torej za ex-ante vidik.

\subsection{Publiciteta poročila}

Poročilo o odvisnosti se javno ne objavi, niti ni sestavni del letnega poročila. Prav tako niti delničarji, niti upniki nimajo pravice zahtevati od poslovodstva, da jim predloži poročilo o odvisnosti. ${ }^{15}$ Razlog za takšno tajnost poročila o odvisnosti je $\mathrm{v}$ varovanju interesa odvisne družbe po zaščiti občutljivih podatkov (npr. podatkov, ki predstavljajo poslovno skrivnost). Da bi poročilo o odvisnosti kljub temu doseglo svoj namen, zakon vzpostavlja mehanizem, po katerem je poročilo o odvisnosti podvrženo dvojni kontroli - eksterni s strani revizorja (glej razdelek 3.1.) in interni s strani nadzornega sveta (glej razdelek 3.2.) - in omejenemu razkritju. $\mathbf{V}$ poslovnem poročilu se razkrije končno pojasnilo iz petega odstavka 545. člena ZGD-1. Poslovno poročilo je sestavni del letnega poročila (primerjaj prvi odstavek 60. člena ZGD-1), ki se objavi v skladu z 58. členom ZGD-1 in razkrije v skladu s tretjim odstavkom 296. člena in drugim odstavkom 297.a člena ZGD-1. Letno poročilo se predloži skupščini po drugem stavku tretjega odstavka 294. člena ZGD-1.

\footnotetext{
15 Zaradi močne pravice do informacij in vpogleda iz 512. člena ZGD-1 je položaj drugačen pri družbi z omejeno odgovornostjo, pri kateri lahko družbenik (na podlagi te pravice) zahteva vpogled tudi v poročilo o odvisnosti (Podgorelec, 2015: 1127).
} 


\section{$3 \quad$ Nadaljnja obravnava poročila o odvisnosti}

\subsection{Revizija}

Če je družba zavezana $\mathrm{k}$ reviziji letnega poročila, mora poročilo o odvisnosti pregledati eksterni revizor (546. člen ZGD-1). Namen z zakonom določene eksterne revizije je trojen:

a) pregled poročila o odvisnosti s strani eksternega eksperta (zakon namreč upošteva, da je nadzorni svet odvisne družbe vsaj delno sestavljen iz članov, ki so po volji obvladujoči družbi, saj ima ta praviloma večino pri glasovanju na skupščini odvisne družbe);

b) revizija poročila o odvisnosti krepi zgoraj omenjeno preventivno funkcijo poročila o odvisnosti;

c) revizorjev pregled in njegovo poročilo sta podlaga nadaljnjemu internemu pregledu s strani nadzornega sveta po 546.a členu ZGD-1.

Revizor mora o rezultatih revidiranja izdelati pisno poročilo, ki ga izroči poslovodstvu (tretji odstavek 546. člena ZGD-1). ${ }^{16}$ Obveznosti, objaviti revizorjevo poročilo o reviziji poročila o odvisnosti, ZGD-1 ne določa. ${ }^{17}$ Namesto tega je izid revizije predmet pregleda s strani nadzornega sveta po 546.a členu ZGD-1.

\subsection{Pregled s strani nadzornega sveta}

Pregled nadzornega sveta iz 546.a člena ZGD-1 je osredotočen na dvoje, in sicer:

a) na preveritev poročila o odvisnosti, in

b) na oblikovanje stališča o izidu revizije poročila o odvisnosti.

Pregled nadzornega sveta iz 546.a člena ZGD-1 je tesno povezan z njegovimi obveznostmi v zvezi s preveritvijo letnega poročila iz 282. člena ZGD-1. O pregledu iz 546.a člena ZGD-1 in o preveritvi iz 282. člena ZGD-1 nadzorni svet poroča $\mathrm{v}$ enovitem poročilu za skupščino iz drugega odstavka 282. člena ZGD1 (drugi odstavek 546.a člena ZGD-1). Drugi do četrti odstavek 546.a člena ZGD-1 določajo dodatno vsebino poročila nadzornega sveta iz drugega odstavka

\footnotetext{
${ }_{16}$ Določbe ZGD-1 o reviziji poročila o odvisnosti dopolnjuje Stališče 2 - Pregled poročila o odnosih do povezanih družb (Slovenski inštitut za revizijo; Ur. l. RS, št. 23/16).

${ }_{17}$ Tudi (Podgorelec, 2015: 1127), navaja, da poročilo o revidiranju poročila o odvisnosti ni javno dostopno.
} 
282. člena ZGD-1, ki se nanaša na pregled in preveritev poročila o odvisnosti ter revizijo poročila o odvisnosti, in sicer mora biti poročilo nadzornega sveta razširjeno $z$ naslednjo vsebino:

- ugotovitve nadzornega sveta o preveritvi poročila o odvisnosti (drugi odstavek 546.a člena ZGD-1),

- $\quad$ stališče nadzornega sveta o izidih revidiranja poročila o odvisnosti (če mora letno poročilo pregledati revizor; tretji odstavek 546.a člena ZGD-1),

- dobesedna navedba (prepis) revizorjevega sklepa ${ }^{18}$ ali pa izrecna navedba, da je revizor dal odklonilen sklep oziroma da je izjavo sklepa zavrnil,

- $\quad$ izjava nadzornega sveta o morebitnih pripombah h končnemu pojasnilu iz petega odstavka 545. člena ZGD-1 (četrti odstavek 546.a člena ZGD-1).

Poročilo nadzornega sveta se razkrije v skladu s tretjim odstavkom 296. člena in drugim odstavkom 297.a člena ZGD-1. Skupščini se predloži po drugem stavku tretjega odstavka 294. člena ZGD-1.

\section{Publicirani podatki in predpostavke individualne pravice predlagati posebno koncernsko revizijo}

Prvi odstavek 546.b člena ZGD-1 daje vsakemu delničarju pravno možnost, da iniciira posebno koncernsko revizijo, če je izpolnjena katera izmed treh formaliziranih predpostavk. ${ }^{19}$ Te predpostavke so vsebovane $\mathrm{v}$ poročilu nadzornega sveta in končnem pojasnilu oziroma $\mathrm{v}$ izjavah poslovodstva ali nadzornega sveta, ki so razvidne iz razkritega poročila nadzornega sveta iz 282. člena ZGD-1 in razkritega končnega pojasnila iz petega odstavka 545. člena ZGD-1. Vse predpostavke so določene $\mathrm{v}$ treh alinejah iz prvega odstavka 546.b člena ZGD-1, njihovo vsebino pa najdemo na sledečih mestih:

a) revizor je dal k poročilu o odvisnosti sklep s pridržki ali odklonilen sklep oziroma je izjavo sklepa zavrnil (prva alineja prvega odstavka 546.b člena ZGD-1): ta predpostavka je vsebovana $\mathrm{v}$ poročilu nadzornega sveta, $\mathrm{v}$ katerem se povzame (dobesedno prepiše) revizorjev sklep ali pa se izrecno

\footnotetext{
${ }_{18}$ Zakonsko besedilo » $V$ poročilu se povzame revizorjev sklep ... « je zavajajoče, saj ne gre za povzetek, temveč za dobesedno navedbo revizorjevega sklepa. Primerjaj tretji stavek drugega odstavka \314 nemškega AktG; (J. Vetter, $v$ (Schmidt, M. Lutter in drugi, 2015: \314, r. š. 16)).

${ }_{19}$ Posebnega revizorja imenuje sodišče $\mathrm{v}$ nepravdnem postopku (prvi odstavek 546.b člena v zvezi s šesto alinejo prvega odstavka 50. člena ZGD-1).
} 
navede, da je revizor dal odklonilen sklep oziroma je izjavo sklepa zavrnil (drugi stavek tretjega odstavka 546.a člena ZGD-1);

b) nadzorni svet je imel pripombe na končno pojasnilo iz petega odstavka 545 . člena ZGD-1 (druga alineja prvega odstavka 546.b člena ZGD-1): ta predpostavka je vsebovana v poročilu nadzornega sveta, na koncu katerega mora nadzorni svet navesti, ali ima na končno pojasnilo kakšne pripombe (četrti odstavek 546.a člena ZGD-1);

c) poslovodstvo je samo izjavilo, da je bila družba z določenimi pravnimi posli ali drugimi dejanji prikrajšana, ne da bi bilo to prikrajšanje nadomeščeno (tretja alineja prvega odstavka 546.b člena ZGD-1): ta predpostavka je posredno razvidna na podlagi petega odstavka 546. člena v zvezi s tretjim odstavkom 546.a člena ZGD-1, saj mora to posebno okoliščino revizor upoštevati pri oblikovanju svojega sklepa (tretji stavek petega odstavka 546. člena ZGD-1), ki je sestavni del poročila nadzornega sveta (drugi stavek tretjega odstavka 546.a člena ZGD-1). Neposredno je ta predpostavka razvidna iz poslovnega poročila, v katerega se vključi končno pojasnilo (peti odstavek 545. člena ZGD-1).

Če izven teh treh formaliziranih predpostavk obstajajo okoliščine, zaradi katerih obstaja vzrok za domnevo, da je prišlo do protipravnih povzročitev prikrajšanj, lahko posebno koncernsko revizijo predlaga manjšina delničarjev, katerih skupni deleži znašajo najmanj desetino osnovnega kapitala ali katerih nominalni znesek ali pripadajoč znesek osnovnega kapitala znaša najmanj 400.000 eurov (drugi odstavek 546.b člena v zvezi z drugim odstavkom 318. člena ZGD-1), poleg tega pa morajo dokazati, da so bili imetniki delnic ali poslovnih ${ }^{20}$ deležev vsaj tri mesece pred vložitvijo predloga (drugi odstavek 546.b člena ZGD-1).

\footnotetext{
${ }^{20} \mathrm{~V}$ zakonskem besedilu je tipkarska napaka. Zakon namreč uporablja izraz »poslovodni deleži«.
} 


\section{$5 \quad$ Sklep}

Vsebino poročila o odvisnosti lahko strnjeno prikažemo shematsko:

\section{Uvod in relevantne družbe}

- Navedejo se relevantne družbe; predvsem pri kompleksnejših povezavah je zaradi načel vestnosti in verodostojnosti (četrti odstavek 545. člena ZGD-1) priporočljivo predstaviti razmerje med njimi.

\section{Podrobni podatki o pravnih poslih in drugih}

\section{dejanjih}

- Pravni posli: (i) naštetje in opis pravnih poslov; (ii) navedba izpolnitve in nasprotne izpolnitve.

-Druga dejanja: (i) naštetje in opis dejanj (vključno z opuščenimi pravnimi posli); (ii) navedba razlogov; (iii) navedba (posebej) koristi in (posebej) prikrajšanj.

- Nadomestitev prikrajšanja: (i) ali so bila prikrajšanja nadomeščena med poslovnim letom in kako so bila nadomeščena; (ii) ali in kateri zahtevki iz četrtega stavka tretjega odstavka 545. člena ZGD-1 so bili ustanovljeni in kako so bili ustanovljeni.

\section{Končno pojasnilo}

-Lastna ocena poslovodstva: (i) ali je odvisna družba pri pravnih poslih vedno prejela ustrezno nasprotno izpolnitev in pri drugih dejanjih ni bila prikrajšana; (ii) (če (i) ne drži) ali je bilo prikrajšanje nadomeščeno. 
Predstavljeno obravnavo poročila o odvisnosti lahko strnjeno prikažemo shematsko:

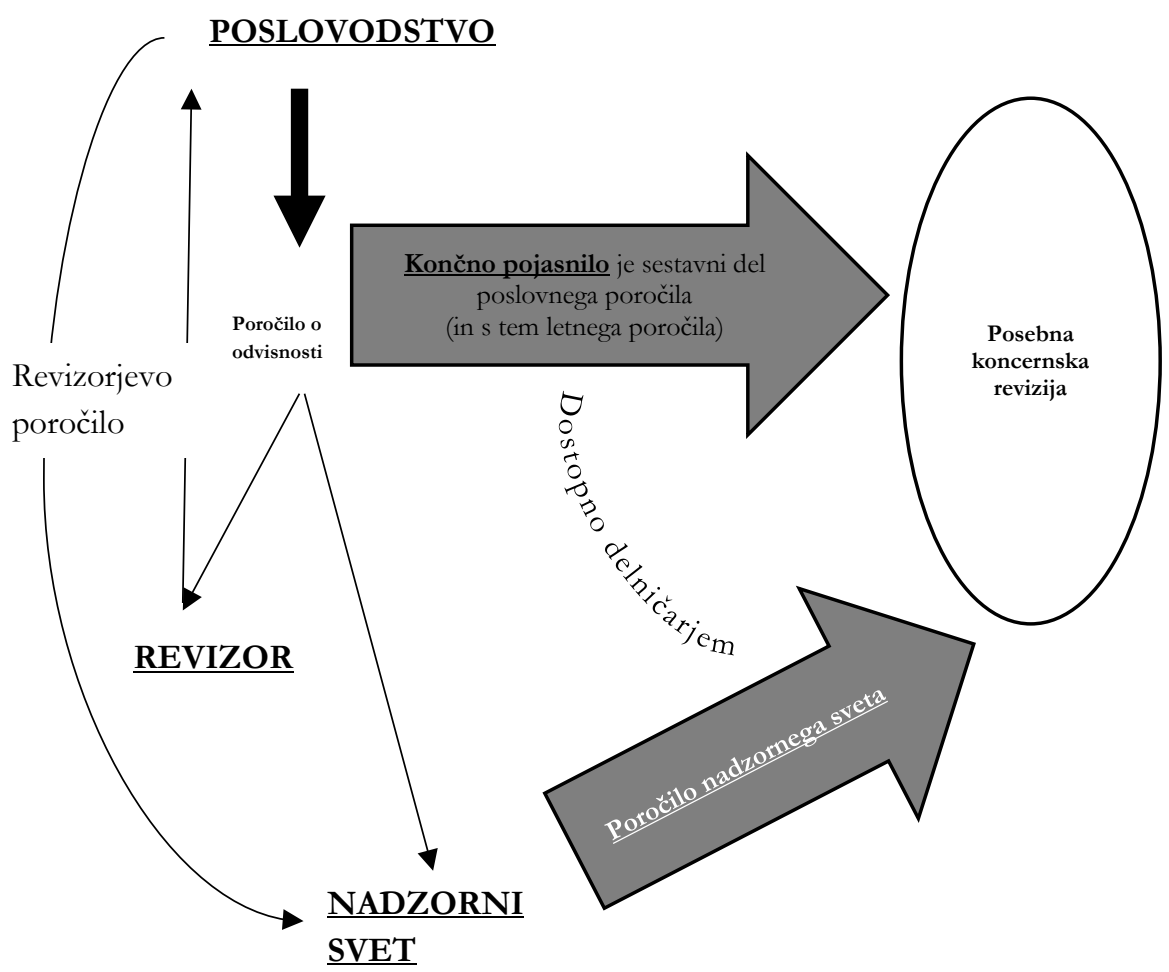

Shema 2: Strnjen prikaz obravnave poročila o odvisnosti

\section{Opomba}

Stališča avtorja v prispevku niso nujno tudi stališča družbe, v kateri je zaposlen.

\section{Literatura}

Drnovšek, G. (2018) Poročilo o odvisnosti, V: Aktualna problematika dejanskega koncerna in poslovanja med koncernskimi družbami: zbornik prispevkov, KPMG pravno-davǒna konferenca (Ljubljana: KPMG poslovno svetovanje, d.o.o).

Hüffer, U. \& Koch, J. (2016) Aktiengesetz (München: C. H. Beck).

Kocbek, M. (2018) Temeljne pravne značilnosti dejanskega koncerna, V: Aktualna problematika dejanskega koncerna in poslovanja med koncernskimi drǔ̌bami: zbornik 
prispevkov, KPMG pravno-davčna konferenca (Ljubljana: KPMG poslovno svetovanje, d.o.o).

Kocbek, M. (2017) Koncepti varovanja odvisnih družb pri dejanskih in pogodbenih koncernih, Podjetje in delo, 43(6/7), str. 933-948.

Plavšak, N., Juhart, M. \& Vrenčur, R. (2009) Obligacijsko pravo: splošni del (Ljubljana: GV založba).

Podgorelec, P. (2018) Odgovornost organov vodenja ali nadzora v dejanskem koncernu, $\mathrm{V}$ : Aktualna problematika dejanskega koncerna in poslovanja med koncernskimi drǔ̌bami: zbornik prispevkov, KPMG pravno-davcna konferenca (Ljubljana: KPMG poslovno svetovanje, d.o.o).

Podgorelec, P. (2015) Podrobnejša pravila varstva upnikov in manjšinskih delničarjev v koncernskem pravu (povezane družbe in podjetniška pogodba), Podjetje in delo, 41(6/7), str. 1120-1132.

Podgorelec, P. (2017) Odškodninski zahtevki odvisnih družb in delničarjev zaradi škodljivih navodil in »finančnih izčrpavanj«, Podjetje in delo, 43(6/7), str. 949-959.

Podgorelec, P., Hauptman L. [in drugi] (2014) Koncerni (Ljubljana: IUS Software, GV založba).

Schmidt, K., Lutter, M. [in drugi] (2015) Aktiengesetz Kommentar, II. Band (Köln: Dr. Otto Schmidt KG).

Schüppen, M., Schaub, B. [in drugi] (2010) Münchener Anwaltshandbuch: Aktienrecht (München: C. H. Beck). 


\title{
Predstavitev in analiza obresti od davčnih obveznosti po slovenskem Zakonu o davčnem postopku
}

\author{
JERNEJ PODLIPNIK
}

Povzetek Članek obravnava obresti od davčnih obveznosti po slovenskem splošnem davčnem zakonu. Veljavna ureditev je zelo zapletena s številnimi obrestnimi merami za različne pravne položaje. Najpomembnejši del članka je pravna analiza pravil o obrestih. Za izvedbo analize avtor najprej pojasni, kaj so obresti, kako se je zakonodaja glede davčnih obresti spreminjala od leta 1997 predvsem zaradi ugotovitev slovenskega ustavnega sodišča, da je bila nekdanja ureditev neustavna, in kakšna je vsebina veljavnih pravil (reforma davčnih obresti iz leta 2016) na to temo. Iz rezultatov pravne analize je razvidno, da veljavna pravila včasih nimajo logike in so morda celo neustavna. V zaključku članka avtor predlaga zakonodajalcu, da spremeni zakonodajo. $V$ ta namen avtor ponudi možne rešitve, ki bi odpravile nelogičnosti in morebitne neustavnosti trenutne ureditve.

Ključne besede: $\bullet$ davek $\bullet$ obresti $\bullet$ zapadlost $\bullet$ zamuda $\bullet$ obrestna mera •

NASLOV AVTORJA: Jernej Podlipnik, Fakulteta za državne in evropske študije, Kranj, Slovenija, Univerza v Ljubljani, Pravna fakulteta, Ljubljana, Slovenija, e-pošta: jernej.podlipnik@pf.uni-lj.si. 


\title{
Presentation and Analysis of Interests on Tax Liabilities under the Slovenian Tax Procedure Act
}

\author{
JERNEJ PODLIPNIK
}

\begin{abstract}
This paper deals with interests on tax liabilities according to the Slovenian general tax law. The valid legal arrangement is very complex with numerous interest rates for different legal situations. The essential part of the article is the legal analysis of the valid rules on interests. In order to provide the analysis, the author first explains what the interests are, how the legislation on tax interests changed since 1997 mostly because the Slovenian Constitutional Court found the former legal arrangement to be unconstitutional, and what the current rules (reform of the tax interests from 2016) on this topic are. The results of the legal analysis show that the valid rules sometimes lack logic and could even be unconstitutional. In the conclusion of the article the author, therefore suggest the legislator to change the arrangement. For this purpose, the author provides possible solutions that would eliminate illogicality and possible unconstitutionality of the current legal order.
\end{abstract}

Keywords: • Tax $・$ Interests $・$ Maturity $\bullet$ Late Payment Interest Rate •

CORRESPONDENCE ADDRESS: Jernej Podlipnik, Faculty for Government and European Studies, Kranj, Slovenia, University of Ljubljana, Faculty of Law, Ljubljana, Slovenia, e-mail: jernej.podlipnik@pf.uni-lj.si. 


\section{Uvod}

Obresti, obravnavane $\mathrm{v}$ tem članku, so $\mathrm{k}$ davkom pripadajoče dajatve, ki jih ureja Zakon o davčnem postopku. ${ }^{1}$ Veljavna ureditev, ki jo je zakonodajalec sprejel z novelo ZDavP-2J leta 2016 in se je začela uporabljati 1. januarja 2017, je nadvse kompleksna. Razlog za kompleksnost je tudi posledica odločitev Ustavnega sodišča iz leta 2004, ki jim zakonodajalec bolj ali manj uspešno sledi ob spremembah zakonodaje na tem področju, predvsem pa želje zakonodajalca, da skuša tudi z obrestmi vplivati na to, da bi zavezanci sami odpravili svoje napake pri vlaganju obračunov davka in davčnih napovedi. Obresti so v davčnem pravu stalnica, zato je presenetljivo, da $\mathrm{v}$ slovenski publicistiki ni poglobljenih strokovnih in znanstvenih razprav na to temo. To je morda tudi vzrok za veljavno ureditev, katere logičnost in tudi ustavnost je $\mathrm{v}$ marsičem vprašljiva. Namen tega članka je vsaj deloma zapolniti to vrzel s predstavitvijo veljavne ureditve in njeno analizo, ki pokaže, da je vprašljiva logičnost in ustavna skladnost nekaterih zakonskih rešitev. Članek je razdeljen na sedem razdelkov. Uvodu sledi razdelek, v katerem je opredeljen pojem obresti, ki jih je treba plačati od davkov. Posebna pozornost je namenjena načelu materialne zakonitosti, ustavnopravni analizi prehodne določbe novele ZDavP-2J, ki je temeljito posegla v sistem obresti, ter zastaranju. Tretji razdelek je vsebuje zgodovinski prikaz obresti od davkov od 1. januarja 1997 dalje, kajti današnje pravno stanje je v določeni meri posledica dveh odločb Ustavnega sodišča, sprejetih leta 2004. V četrtem razdelku so prikazane obresti, kot jih vsebuje veljavni ZDavP-2, z njim povezan peti razdelek pa je najpomembnejši za ta članek, saj vsebuje kritično analizo veljavne ureditev, in sicer tako splošno kot tudi posameznih »čudnih« zakonskih rešitev. Zaradi primerjave z ureditvijo obresti na ravni Evropske unije, je $v$ šestem razdelku prikazano, kako se obresti obračunavajo pri carinah. Tam so pravila bistveno enostavnejša $\mathrm{v}$ primerjavi $\mathrm{s}$ kompleksnim sistemom $\mathrm{v}$ ZDavP-2. Članek zaključuje sedmi razdelek, ki sprva vsebuje pobudo za reformo veljavnega sistema, hkrati pa so nanizane ideje iz analize, na kakšen način bi bilo to mogoče storiti.

\footnotetext{
${ }^{1}$ Zakon o davčnem postopku (ZDavP-2), Uradni list RS, 13/2011 - uradno prečiščeno besedilo, 32/2012, 94/2012, 101/2013 - ZDavNepr, 111/2013, 25/2014 - ZFU, 40/2014 -ZIN-B, 90/2014, 91/2015, 63/2016, 69/2017 in 13/2018 - ZJF-H.
} 


\section{Obresti v pravu s poudarkom na obrestih od davkov}

\subsection{Pojem in funkcija obresti}

Obresti v davčnem pravu spadajo poleg stroškov postopka pobiranja davkov, denarnih kazni in glob ter stroškov postopka o prekršku, ki jih odmeri oziroma izreka davčni organ, med tako imenovane pripadajoče (stranske) dajatve. ${ }^{2}$ Po stališču Ustavnega sodišča Republike Slovenije (sklep U-I-73/99 z dne 20. 3. 2003) se po funkciji obresti v davčnem pravu ne razlikujejo od tiste, ki velja $\mathrm{v}$ civilnem obligacijskem pravu, kjer so obresti nadomestilo za uporabo tujega denarja ali druge nadomestne stvari (Ax, Große, Melchior, Lotz, \& Ziegler, 2017), lahko pa so poleg tega tudi pravna sankcija za zamudo, kadar dolžnik svoje obveznosti ne izpolni ob nastopu zapadlosti (Plavšak, Juhart, \& Vrenčur, 2009), če ni posebej določen kakšen dodaten pogoj za nastanek zamude (Iglič Stroligo, 2011). Sankcioniranje je predvsem namenjeno zagotavljanju spoštovanja zakonodaje (spodbujevalna funkcija). Obresti so torej v tem primeru vzvod, $\mathrm{s}$ katerim se želi doseči spoštovanje zakonodaje. ${ }^{3}$ Kadar so obresti tak vzvod, po stališču Ustavnega sodišča Republike Slovenije (odločba U-I-356/02 z dne 23. 9. 2004) ne izključujejo nujno kaznovalnih sankcij (npr. prekrškovnih).

Kot pripadajoče dajatve so obresti odvisne od obstoja glavnice, ki je v davčnem pravu denarna obveznost iz naslova davčnopravnega razmerja (Kruse, 1991). Praviloma se obrestujejo le glavne obveznosti iz davčnopravnega razmerja, vendar pa $\mathrm{v}$ nekaterih primerih zakonodaja omogoča tudi obrestovanje pripadajočih dajatev (npr. obrestovanje obresti).

Obresti deli pravna teorija po različnih kriterijih (Brus, 2014). Tipična delitev obresti glede na pravni temelj (Strohsack, 1996), ki razlikuje med zakonskimi in pogodbenimi obrestmi, je $\mathrm{v}$ davčnem pravu brezpredmetna, ker so vse obresti zakonske. Zakon določa, $\mathrm{v}$ katerih primerih obresti tečejo, kdaj začnejo teči in kdaj prenehajo, od katere glavnice tečejo, kolikšna je obrestna mera ipd. Za ta prispevek je bolj pomembna delitev glede na nastanek zamude, ${ }^{4}$ ki obresti deli na

\footnotetext{
2 Četrti odstavek 3. člena ZDavP-2.

${ }^{3} \mathrm{~V}$ Zvezni republiki Nemčiji imajo obresti v davčnem pravu zgolj funkcijo nadomestila za uporabo tujega denarja, ne pa tudi funkcije spodbujanja spoštovanja zakonodaje ali kaznovalne funkcije (Lammerding, Scheel, \& Brehm, 2012). Spodbujanju spoštovanja zakonodaje so tam namenjeni drugi instituti davčnega prava, npr. pribitek za opustitev oddaje davčne napovedi (nem. Verspätungszuschlag) in pribitek za opustitev pravočasnega plačila davka (nem. Säumniszuschlag), ne pa obresti (Birk, Desens, \& Tappe, 2014).

${ }_{4}^{4}$ Brus (2014) sicer piše tudi, da je razlika med zamudnimi in nezamudnimi obrestmi v pravočasnosti plačila, kar pa se ne zdi najbolj natančno. Pravočasnost plačila je namreč povezana z zapadlostjo, ko sicer res največkrat
} 
zamudne in nezamudne (Brus, 2014), o čemer bo več napisanega $\mathrm{v}$ nadaljevanju pri obravnavi zamudnih obresti.

\subsection{Načelo materialne zakonitosti in obresti od davkov}

Čeprav so obresti v davčnem pravu urejene predvsem v ZDavP-2, so določbe, ki urejajo to področje, materialnopravne narave (Jerovšek, in drugi, 2008), kar je tudi stališče sodne prakse (sodba Vrhovnega sodišča X Ips 378/2016 z dne 25. 4. 2018). Zakonodajalec se je glede obresti odločil, da vseh vprašanj ne bo uredil ločeno, ampak bo zaradi zapolnitve pravne praznine uporabil zakonodajno tehniko, s katero je predpisal, da se tudi za obresti uporabljajo določbe, ki veljajo za davek, če zakon ne določa drugače. To ima za posledico, da je ureditev obresti $\mathrm{v}$ zakonu relativno skopa, uporaba določb o davkih pa zahteva določeno mero interpretacije.

Predvsem pri zakonskih spremembah, s katerimi se je spreminjala višina obrestne mere, se zastavlja vprašanje, katere določbe je treba uporabiti, če zakonodajalec tega vprašanja ne uredi, kadar pa ga s prehodno določbo uredi na način, da predpiše, da je treba povišano obrestno mero uporabiti tudi za obdobje pred spremembo, pa se postavlja vprašanje ustavne ustreznosti take zakonske rešitve. ${ }^{5}$

Načelo zakonitosti $\mathrm{v}$ davčnih zadevah, ki velja za davčni organ, ${ }^{6}$ je urejeno $\mathrm{v}$ prvem odstavku 4. člena ZDavP-2, ki se glasi: »Davčni organ odloča v davčnih zadevah samostojno $\mathrm{v}$ okviru in na podlagi mednarodnih pogodb, ki obvezujejo Republiko Slovenijo, zakonov in splošnih aktov po tem zakonu, zakonu, ki ureja finančno upravo ali zakonu o obdavčenju.«ne daje odgovora na vprašanje, katero pravo je treba uporabiti s časovnega vidika $\mathrm{v}$ primerih, ko zakonodajalec vprašanja ne uredi izrecno, zato je treba do rešitve priti s pomočjo razlage, ki mora biti skladna z Ustavo. ${ }^{7}$ Gre torej za podoben problem, ki nastane tudi pri uporabi načela zakonitosti po ZUP, o čemer je pravna teorija že razpravljala (Kerševan, 2008). Čeprav se običajno vsebina načela zakonitosti razlaga na način,

\footnotetext{
nastopi tudi zamuda, toda ne vselej. Zapadlost je torej treba ločiti od zamude (Iglič Stroligo, 2011), ne glede na to da zamuda najpogosteje nastopi skupaj z zapadlostjo.

${ }^{5}$ Analiza ustavne ustreznosti prehodne ureditve je narejena na primeru 71. člena novele ZDavP-2J (točka 2.2.1).

${ }^{6}$ Kadar davkov ne izračunava davčni organ, ampak to počnejo zavezanci sami, načelo zakonitosti izhaja iz 9. člena ZDavP-2 (Podlipnik, 2015).

7 Ustava Republike Slovenije (Ustava), Uradni list RS, št. 33/1991-I, 42/1997 - UZS68, 66/2000 - UZ80, 24/2003 - UZ3a, 47, 68, 69/2004 - UZ14, 69/2004 - UZ43, 69/2004 - UZ50, 68/2006 - UZ121,140,143, 47/2013 - UZ148, 47/2013 - UZ90,97,99 in 75/2016 - UZ70a.
} 
da je treba praviloma uporabiti predpis, ki velja v času odločanja na prvi stopnji (Grafenauer \& Breznik, 2009), pa je taka interpretacija netočna, saj ji manjka dostavek, da to ne velja $\mathrm{v}$ primerih, ko je pravno razmerje nastalo pred uveljavitvijo predpisa, in je zato treba pravno razmerje obravnavati po prejšnjem predpisu (Kerševan \& Androjna, 2017). ${ }^{8}$ Za oceno, katero materialno pravo je treba uporabiti pri obrestih $\mathrm{v}$ davčnem pravu, je torej treba ugotoviti, ali pravno razmerje med upnikom (terjatev iz naslova obresti) in dolžnikom (obveznost iz naslova obresti) nastane »šele« $\mathrm{z}$ aktom (odločba ali obračun) ali neposredno na podlagi zakona, ko se zgodijo okoliščine, zaradi katerih je treba obresti plačati.

Kot je že bilo zapisano, se glede obresti uporabljajo pravila, ki veljajo za davke, če ni posebej drugače določeno. Glede davkov pa teorija (Podlipnik, 2015) in sodna praksa Vrhovnega sodišča (sodba X Ips 179/2013 z dne 27. 11. 2014) menita, da pravno razmerje nastane neodvisno od akta, $\mathrm{v}$ katerem je ta obveznost ugotovljena, saj imajo ti akti ugotovitveno (deklaratorno) naravo. Enako torej velja tudi za obresti, kar je glede zamudnih obresti v davčnem pravu pravna teorija že potrdila z navedbo, da te tečejo po samem zakonu (ipso iure), ko nastopi zamuda (Šinkovec \& Tratar, 2002), enako pa je tudi stališče teorije v Zvezni republiki Nemčiji (Birk, Desens, \& Tappe, 2014). Tudi Ustavno sodišče (odločba U-I-300/04 z dne 2. 3. 2006) je, sicer za obresti v civilnem pravu, kar pa ne bi smelo pomeniti, da v davčnem pravu velja drugače, navedlo podobno: »Čeprav so obresti ob nastanku obveznost akcesorne narave, so posamezni zneski zapadlih obresti potem, ko nastanejo, samostojne terjatve in je z njimi mogoče samostojno razpolagati. Zakonske zamudne obresti so samostojne tudi $\mathrm{v}$ pravnem naslovu, saj imajo svojo podlago v zakonu. Čas nastanka obligacijskega razmerja tudi ne vpliva na višino obrestne mere, ki se je zaradi spreminjajočih se gospodarskih razmer spreminjala. Če je bila $\mathrm{v}$ času trajanja zamude določena nova obrestna mera zamudnih obresti, so se zamudne obresti od dneva uveljavitve spremembe dalje obračunavale po novi obrestni meri.«

\footnotetext{
${ }^{8}$ Opozoriti pa je treba, da bi bilo z vidika pravne varnosti pomembno zagotoviti pravno podlago za nadaljnjo uporabo ne več veljavnih določb. to je mogoče storiti na dva načina: s prehodno določbo ali z generalno določbo, kot je denimo 2. člen Zakona o dohodnini (ZDoh-2), Uradni list RS, št. 13/2011 - uradno prečiščeno besedilo, 9/2012 - odl. US, 24/2012, 30/2012, 40/2012 - ZUJF, 75/2012, 94/2012, 52/2013 - odl. US, 96/2013, 29/2014 - odl. US, 50/2014, 23/2015, 55/2015, 63/2016 in 69/2017, ki se glasi: »Dohodnina se ugotavlja po določbah zakona, ki velja na dan 1. januarja leta, za katero se dohodnina odmerja, če ni s tem zakonom drugače določeno.« V izogib primerom, ko bi zakonodajalec pomotoma pozabil napisati ustrezno prehodno določbo, s katero bi podaljšal uporabo razveljavljenih določb, bi bilo dobro po zgledu nekaterih drugih držav že v ZDavP-2 vnesti določbo, ki bi na ustavno-skladen način uredila to vprašanje (Podlipnik, 2015).
} 
Iz zapisanega sledi, da je obrestno-pravno razmerje, kljub akcesornosti po pravnem temelju (sklep Ustavnega sodišča U-I-73/99 z dne 20. 3. 2003), ločeno od temeljnega razmerja, nastane pa, ko so za to izpolnjeni pogoji, ki jih predpisuje davčni zakon, neodvisno od akta, v katerem so obresti ugotovljene. Posledično je treba ob odsotnosti zakonske ureditve, ki ureja to vprašanje, pri ugotavljanju višine obresti uporabiti tiste materialnopravne določbe, ki so veljale $\mathrm{v}$ času, ko so obresti tekle. Če so se te določbe v obdobju teka obresti spreminjale, je treba uporabiti vsakokrat veljavne. V nasprotnem primeru se lahko zgodi, da se za določeno pravno razmerje uporabi pravo, ki v času njegovega nastanka sploh ni veljalo.

\subsubsection{Analiza ustavne ustreznosti 71. člena novele ZDavP-2J}

$\mathrm{Ob}$ spreminjanju zakonodaje zakonodajalec ni povsem svoboden pri sprejemanju prehodne ureditve za primere, ko so pravna razmerja nastala že pred spremembo, ampak ga pri tem omejujejo določbe Ustave. Zakonodajalec mora tako sprejeti rešitev, ki je skladna z načelom zaupanja $\mathrm{v}$ pravo (2. člen Ustave), ki nedopustno ne posega $v$ zaključena pravna razmerja (155. člen Ustave), čeprav ta morda še niso stabilizirana v odločbi (odločba Ustavnega sodišča U-I-340/96 $\mathrm{z}$ dne 12. 3. 1998), ter $\mathrm{v}$ načelo enakosti pred zakonom (14. člen Ustave). Prehodna določba, ki jo vsebuje 71. člen novele ZDavP-2J, predstavlja nedopusten poseg zakonodajalca $\mathrm{v}$ omenjene pravice. 
Prehodna določba 71. člena novele ZDavP-2J se glasi:

(1) Zadeve, glede katerih je postopek ob začetku uporabe tega
zakona v teku, se končajo po tem zakonu.
(2) Zadeve, glede katerih je bilo ob začetku uporabe tega zakona
že vloženo pravno sredstvo oziroma začet upravni spor, se
končajo po Zakonu o davčnem postopku (Uradni list RS, številka
$13 / 11$ - uradno prečiščeno besedilo, $32 / 12,94 / 12,101 / 13$ -
ZDavNepr, $111 / 13,22 / 14$ - odl. US, $25 / 14-$ ZFU, $40 / 14-$
ZIN-B, $90 / 14$ in $91 / 15)$.
(3) Če je bilo uporabljeno pravno sredstvo oziroma začet upravni
spor po prejšnjem odstavku in je bila izdana odločba odpravljena
in zadeva vrnjena v ponovni postopek, se postopek nadaljuje po
tem zakonu.

Pravna teorija (Jerovšek, in drugi, 2008) in sodna praksa (sodba Vrhovnega sodišča X Ips 42/2010 z dne 16. 6. 2011, in sodba Vrhovnega sodišča X Ips 239/2013 z dne 3. 10. 2013) o 418. členu ZDavP-2, ki je vsebinsko enak 71. členu ZDavP-2J, menita, da se nanaša na tako na procesne kot tudi na materialnopravne določbe. To stališče je glede na zakonsko dikcijo ustrezno, vendar pa (tudi) glede določb o obrestih povzroča spornost ureditve $z$ vidika Ustave. Zvišanje obrestnih mer, ki se je zgodilo z novelo ZDavP-2J, je povzročilo, da so (nekateri) zavezanci tudi za obdobje, ko novela sploh še ni veljala, dolžni plačati obresti, ki jim sproti sploh niso nastajale, saj je bila obrestna mera nižja (kršitev 2. in 155. člena Ustave). Vrhovno sodišče je glede tega argumenta pri presoji 418. člena ZDavP-2 ugotovilo, da naj bi se 155. člen Ustave uporabljal le za pravna razmerja, ki so bila zaključena, za kar pa naj pri obrestih ne bi šlo. To stališče pa je vprašljivo, če ga primerjamo z že omenjenim stališčem Ustavnega sodišča (odločba U-I-300/04 z dne 2. 3. 2006), ki se sicer nanaša na civilnopravne obresti, da so obresti ob nastanku posameznega zneska samostojne terjatve. Tudi ni jasno, kdaj se tako pravno razmerje zaključi, če se ne zaključuje sproti (npr. vsak dan zamude pri zamudnih obrestih). Pri davkih je denimo Ustavno sodišče (odločba U-I-158/11 z dne 28. 11. 2013) že presodilo, da (dokončen) nastanek davčne obveznosti ni bistven za vprašanje uporabe 155 . člena Ustave (prava retroaktivnost), zato ni popolnoma jasno, zakaj bi moralo to 
veljati za davčne obresti. ${ }^{9} \mathrm{Z}$ vidika načela enakosti pred zakonom pa bi bilo sporno, če bi bil zaključek pravnega razmerja odvisen od dela državnih organov (npr. izdaja odločbe). Prehodna ureditev povzroča neenako obravnavo med zavezanci, pri katerih se je postopek za isto obdobje zaključil pred začetkom uporabe zakona in kasneje njihova odločba ni bila odpravljena ter vrnjena $\mathrm{v}$ ponoven postopek, in med tistimi zavezanci, pri katerih se je postopek začel po začetku uporabe zakona oziroma je bila kasneje odločba odpravljena in vrnjena v ponoven postopek. Razlikovanje med temi zavezanci ne temelji na razumnem in stvarnem razlogu, ki bi izhajal iz narave stvari, ampak temelji na učinkovitosti dela državnih organov, za kar je Ustavno sodišče v svoji praksi že ugotovilo, da predstavlja arbitraren razlog za razlikovanje (odločba Up-492/11 z dne 9. 5. 2013). Še najbolj sporen je glede tega tretji odstavek 71. člena novele ZDavP-2J, kjer $\mathrm{v}$ praksi davčni organi zavezancem $\mathrm{v}$ ponovnih postopkih odmerjajo obresti po višji obrestni meri, čeprav so celotno obveznost plačali že na podlagi prvotne odločbe, izdane pred začetkom uporabe novele ZDavP-2J. V teh primerih drugostopenjski davčni organi, namesto da bi sami odpravljali napake prvostopenjskih organov, kar je njihova primarna naloga po ZUP (251. člen), vračajo zadeve $\mathrm{v}$ ponovne postopke prvostopenjskim davčnim organom, ki $\mathrm{v}$ primerih ponovnih odmer, zavezancem naložijo v plačilo višje obresti, kar je že bilo kritično ovrednoteno v strokovni publicistiki (Podlipnik, 2018).

\subsection{Obresti od davkov in zastaranje}

Pravila civilnega obligacijskega prava glede zastaranja obresti določajo, da obresti zastarajo skupaj z zastaranjem glavne terjatve (344. člen Obligacijskega zakonika), ${ }^{10}$ če prej ne poteče krajši triletni zastaralni rok (prvi odstavek 347. člena OZ), ki velja zanje (Cigoj, 1998). ${ }^{11}$ Splošnih pravil, ki bi določala samostojno zastaranje obveznosti iz naslova obresti, čeprav glavnica ne preneha,

\footnotetext{
${ }^{9} \mathrm{~V}$ tem smislu tudi pravna teorija, ki je ob uvajanju obresti v postopkih davčnega nadzora zapisala: »Obresti po medbančni obrestni meri EURIBOR pa so se $\mathrm{v}$ postopkih davčnega inšpekcijskega nadzora $\mathrm{v}$ skladu $\mathrm{z}$ določbo 30.a člena ZDavP-1 začele zaračunavati od 1. januarja 2005 dalje. Pred tem datumom te obresti še niso bile uveljavljene, zato se v primerih, ko se postopek davčnega inšpekcijskega nadzora opravlja za obdobje pred 1. januarjem 2005, obresti po medbančni obrestni meri za ta čas ne zaračunavajo, saj bi šlo po mnenju Službe Vlade RS za zakonodajo za retroaktivno uporabo zakona.« (Jerovšek, in drugi, 2008).

${ }^{10}$ Obligacijski zakonik (OZ), Uradni list RS, št. 97/2007 - uradno prečiščeno besedilo, 64/2016 - odl. US in 20/2018 - OROZ631.

11 Tudi sicer ima zastaranje $\mathrm{v}$ davčnem pravu drugačen pomen kot v civilnem obligacijskem pravu, kajti ne pomeni le prenehanje pravice do sodnega varstva (Plavšak, Juhart, Kranjc, Polajnar Pavčnik, \& Grilc, 2003), ampak prenehanje same pravice, torej njeno prekluzijo, kar sta potrdili tako teorija (Muha, 2017; Škof, 2007) kot sodna praksa (sodba Upravnega sodišča I U 765/2015 z dne 6. 9. 2016). Enako denimo velja tudi v Zvezni republiki Nemčiji (Maier \& Grimm, 2014).
} 
davčna zakonodaja ne vsebuje, zato je treba uporabiti pravila, ki veljajo za davke. V praksi obveznost plačati obresti zastara skupaj z zastaranjem glavnice. Izjema je 126.a člen ZDavP-2, ki določa, da zamudne obresti zastarajo s pretekom absolutnega zastaralnega roka, čeprav davčna obveznost, ki je zavarovana s hipoteko in je glede nje že pred potekom roka za izvršbo vložen predlog za izvršbo na nepremičnino, ne zastara. Ni popolnoma jasno, zakaj zakonodajalec omenja le zamudne obresti, ne pa ostalih vrst obresti. Predlog novele ZDavP2B, s katero je bila ta določba dodana, omenja 343. člen OZ, ki pa ni omejen zgolj na zamudne obresti, ampak velja za vse vrste obresti.

\section{$3 \quad$ Ureditev obresti od davkov v preteklosti (od 1. 1. 1997 dalje)}

\subsection{Prvi Zakon o davčnem postopku ${ }^{12}$}

Dne 1. januarja 1997 se je začel uporabljati ZDavP, ki je poznal le eno višino obrestne mere, in sicer $\mathrm{v}$ višini obrestne mere zamudnih obresti. To sicer ne pomeni, da so bile vse obresti, ki jih je ta zakon urejal po svoji vsebini zamudne obresti, toda to razlikovanje glede na takratno ureditev ni bilo bistveno. V 100. členu ZDavP je bilo tako določeno, da je dolžan zavezanec ali izplačevalec dohodkov, od davkov, ki jih ni plačal v predpisanem roku, plačati obresti v skladu z zakonom, ki ureja obrestno mero zamudnih obresti. Celo če je davčni organ odložil izvršbo (prisilno izterjavo), ker je ocenil, da bi bilo vloženi pritožbi mogoče ugoditi, je moral zavezanec na podlagi 20. člena ZDavP za to obdobje plačati obresti $\mathrm{v}$ višini obrestne mere zamudnih obresti1 ${ }^{13}$ (te obresti po svoji naravi seveda niso bile zamudne obresti, kajti zavezancu je bil dovoljen odlog, kar pomeni, da ni bil v zamudi). ${ }^{14}$ Obresti pa niso tekle, če je bil zavezancu odobren odlog iz drugih razlogov (92. člen ZDavP).

\footnotetext{
${ }^{12}$ Zakon o davčnem postopku (ZDavP), Uradni list RS, št. 18/1996, 87/1997, 35/1998 - odl. US, 82/1998, 91/1998, 1/1999 - ZNIDC, 108/1999, 37/2001 - odl. US, 97/2001, 105/2003 - odl. US, 16/2004 - odl. US in 54/2004-ZDavP-1.

${ }^{13}$ Ureditev, kot jo je nekdaj vseboval ZDavP, imajo še vedno v Srbiji (Popović, 2003) in na Hrvaškem (Antolić, in drugi, 2009).

${ }^{14}$ Zavezanec ni bil dolžan plačati obresti, če je s pritožbo uspel in je bila odločba odpravljena (sodba Vrhovnega sodišča U 410/92 z dne 4. 3. 1993). Omeniti velja, da je to lahko veljalo le za primere, ko je bila zapadlost vezana na izdajo odločbe.
} 


\subsection{Odločbi Ustavnega sodišča}

V to ureditev je leta 2004 poseglo Ustavno sodišče z dvema odločbama. Z odločbo U-I-233/01 z dne 5. 2. 2004 je Ustavno sodišče razveljavilo drugi stavek drugega odstavka 20. člena ZDavP, ker je nasprotoval 2. členu Ustave (pravna in socialna država), kajti določba je povzročala notranje nasprotje znotraj pravnega reda (anomija). Ustavno sodišče je menilo, da položaj, ko davčni organ odobri zavezancu, da mu davka ni treba plačati, hkrati pa mu za ta čas zaračuna obresti v višini zamudnih obresti, "pri prizadetih vzbuja negotovost in dvom v doslednost pravnega reda in stabilnost prava.« Če ja namen zakonodajalca omiliti položaj prizadetega subjekta, »ni dopustno takšno nadaljnje urejanje področja, ki povsem izvotli [...] omilitev«. ${ }^{15}$ Ureditev je bila glede na to, da obrestna mera zamudnih obresti obsega tudi določen pribitek, ki naj bi zagotavljal, da bi dolžnik čim prej izpolnil svojo obveznost, res nenavadna (nelogična), saj je odlagala izpolnitev, obenem pa silila $\mathrm{k}$ njej. Ustavno sodišče je $\mathrm{v}$ zaključku še dodalo, da bi zakonodajalec $\mathrm{v}$ takih primerih lahko predpisal »obrestovanje, ki bi zagotavljalo ohranjanje realne vrednosti denarja«.

Odločba U-I-356/02 z dne 23. 9. 2004 je bila sprejeta že v času, ko je ZDavP prenehal veljati, se je pa še uporabljal (do konca leta 2004). Ustavno sodišče tako ni razveljavilo 100. člena ZDavP, saj ta ni več veljal, ampak je ugotovilo njegovo neustavnost zaradi njegove neskladnosti $z$ 2. členom Ustave. Po presoji Ustavnega sodišča zavezanci, ki so bili sami dolžni izračunavati davčno obveznost (samoobdavčitev), niso mogli vnaprej predvideti svojega pravnega položaja, kajti znesek obresti $\mathrm{v}$ višini zamudnih obresti, ki jim je bil naložen $\mathrm{z}$ odločbo, je bil odvisen od tega, kako davčni organ razlaga davčne predpise in kdaj v okviru zastaralnega roka izda odmerno odločbo. Ustavno sodišče v odločbi naredi ločnico med zapadlostjo davčne obveznosti in zamudo z njeno izpolnitvijo ter sprejme stališče, da zamudne obresti ne morejo vselej začeti teči z zapadlostjo obveznosti, ampak mora za začetek njihovega tega nastati tudi zamuda. ${ }^{16}$ Ta pa nastopi šele, če je davčna obveznost individualizirana in konkretizirana $\mathrm{v}$ aktu, ki ga bodisi izda davčni organ (odmerna odločba) ali

\footnotetext{
${ }_{15}^{15}$ Dodati velja, da je odlog sicer preprečeval davčnemu organu, da bi zneske lahko prisilno izterjal, vendar pa se očitno to Ustavnemu sodišču ni zdelo dovolj.

${ }^{16} \mathrm{~S}$ tega vidika je torej deloma napačno stališče Vrhovnega sodišča v sodbi X Ips 378/2016 z dne 27. 9. 2016, ki enači zapadlost in zamudo. Zamuda sicer lahko nastopi hkrati z zapadlostjo, ni pa to nujno. Ustavno sodišče je v odločbi U-I-356/02 z dne 23. 9. 2004 opozorilo, da pri davkih, ki so jih zavezanci dolžni obračunati sami, zamuda ne nastopi z zapadlostjo, če zavezanec obračuna premalo davkov, ampak zamuda nastopi šele $z$ izvršljivostjo izvršilnega naslova, ki korigira napačen obračun.
} 
zavezanec za davek (obračun davka), obenem pa mine rok za izpolnitev (t. i. izpolnitveni ali paricijski rok), s čimer akt postane izvršljiv. Ustavno sodišče pri tem obitur dictum ponovi svoje stališče iz zgoraj obravnavane odločbe glede možnosti, da zakonodajalec za čas med zapadlostjo in izvršljivostjo (nastanek zamude) predpiše tek obresti, ki bi ohranjale realno vrednost denarja (valorizacija).

\subsection{Drugi Zakon o davčnem postopku ${ }^{17}$}

Osnovni zakon je vseboval rešitev glede odlogov plačil davka. Zakonodajalec je to vprašanje enotno uredil za vse vrste odlogov (38., 121. in 142. člen). ${ }^{18}$ Po teh določbah so se zavezancem za čas, ko jim je bilo odloženo plačilo davka oziroma dovoljeno obročno plačilo, od odloženih zneskov zaračunale obresti po slovenski medbančni obrestni meri za ročnost glede na čas, za katerega je bi odobren odlog oziroma obročno plačilo, ki je veljala na dan izdaje odločitve o odlogu oziroma obročnem plačilu. Zakonodajalec je torej za vse vrste odlogov, torej tudi za tiste, glede katerih prej ni zaračunaval obresti, predpisal obrestovanje na način, kot ga je "predlagalo« Ustavno sodišče. ${ }^{19} \mathrm{Z}$ novelo ZDavP-1B je bil 38. člen deloma dopolnjen, vendar na način, ki ni pomemben za ta prispevek.

$\mathrm{Ob}$ upoštevanju izdaje odločbe Ustavnega sodišča po sprejemu osnovnega besedila ZDavP-1 v državnem zboru, vendar pa pred začetkom njegove veljavnosti, je zakonodajalec novelo ZDavP-1A sprejel že pred 1. januarjem 2005. V njej osnovnemu besedilu dodal 30.a člen in vsebinsko deloma spremenil 31. člen. Če je bila prvotna ureditev ZDavP-1 enaka tisti po ZDavP, ko so se zavezancem vselej, razen pri obročnih plačilih in odlogih, obračunavale obresti po obrestni meri zamudnih obresti, je zakonodajalec to vprašanje z obravnavano novelo uredil v skladu z »napotilom« Ustavnega sodišča (Tratar \& Kruhar Puc, 2005). Uvedel je novo kategorijo obresti in jih poimenoval obresti v postopku davčnega nadzora. Od nastanka obveznosti do izdaje odločbe zavezancem ni bilo več treba plačevati obresti po obrestni meri za zamudne obresti, ampak obresti po letni slovenski medbančni obrestni meri, ki je bila nižja od obrestne mere zamudnih obresti. Na ta način je bilo zagotovljeno, da država v času od nastanka obveznosti pa do takrat, ko je davčni organ to obveznost konkretiziral v odločbi,

\footnotetext{
17 Zakon o davčnem postopku (ZDavP-1), Uradni list RS, št. 54/2004, 57/2004 - ZDS-1, 139/2004, 96/2005 - ZRTVS-1, 109/2005 in 117/2006 - ZDavP-2.

${ }_{18}$ Opozoriti velja, da je zakon glede o obračunavanja obresti štel za o odloženo plačilo tudi plačilo po obračunu, vloženem po izteku predpisanega roka (16. člen ZDavP-1).

${ }^{19}$ Del teorije (Škof, O nekaterih dilemah novega Zakona o davčnem postopku, 2004) je to rešitev kritiziral.
} 
ne bi izgubljala zaradi izgube realne vrednosti denarja. Z novelo ZDavP-1B je bil člen deloma dopolnjen, kar pa za ta prispevek ni bistvenega pomena.

ZDavP-1 je v 31. členu ohranil tudi kategorijo zamudnih obresti, ki jih je bil po sprejemu novele ZDavP-1A dolžan plačati zavezanec, ki je bil $\mathrm{v}$ zamudi $\mathrm{z}$ izpolnitvijo obveznosti. Novela ZDavP-1B je v slovensko davčno ureditev vnesla nov institut, in sicer samoprijavo. Zakonodajalec je zanjo predpisal, da se obračunavajo obresti po letni evropski medbančni obrestni meri, ki pa je bila glede na čas, ki je potekel od roka, $v$ katerem je bilo treba vložiti obračun ali napoved, in trenutka, ko sta bila vložena, povečana za določen kazenski pribitek (Podlipnik, 2011). Namen pribitka je bil, da bil spodbuditi zavezance $\mathrm{k}$ čimprejšnji vložitvi samoprijave, saj so morali na ta način plačati nižje obresti (Jerovšek, in drugi, 2008).

\subsection{Tretji Zakon o davčnem postopku}

V prvotnem besedilu ZDavP-2, ki je začel veljati 1. januarja 2007, je zakonodajalec $\mathrm{v}$ pretežni meri ohranil ureditev iz ZDavP-1. Sprememb glede obresti je bilo z nadaljnjimi novelami precej, toda osnovna delitev na obresti pri odlogih ali obročnih plačilih, obresti $\mathrm{v}$ postopku nadzora, obresti pri samoprijavah in zamudne obresti, se je ohranila. V bistvenem so se ohranile tudi obrestne mere, saj so bili zakonski popravki bolj ali manj tehnične narave. Pomembno pa je v ureditev glede obresti zakonodajalec posegel 1. januarja 2017, ko se je začela uporabljati novela ZDavP-2J. Ta je v slovenski pravni red vnesla ureditev, ki velja še danes, zato bo predstavljena v naslednji točki.

\section{$4 \quad$ Predstavitev današnje ureditve obresti od davkov}

\subsection{Obresti pri odlogih in obročnih plačilih ( 2 odstotka letno)}

ZDavP-2 (87, 104. in 157. člen) določa, da obrestna mera pri odlogih in obročnih plačilih praviloma znaša 2 odstotka letno. Le pri tistih zavezancih, ki opravljajo dejavnost, je predpisano, da ja $\mathrm{v}$ višini referenčne obrestne mere za izračun državne pomoči, ki jo objavi Evropska komisija, kadar bi bila ta višja od 2 odstotkov letno. Razlog za tako ureditev je preprost. Če bi namreč država osebam, ki opravljajo dejavnost, obrestovala odloge in obročna plačila po 
obrestni meri, ki je nižja od tiste, ki velja za državne pomoči, bi se to lahko štelo za nedovoljeno državno pomoč.

ZDavP-2 (87. in 157. člen) od 1. januarja 2017 tudi izrecno predpisuje, da se obresti $\mathrm{v}$ primerih odloga zaradi vložene pritožbe zoper odmerno odločbo ali sklep o izvršbi obračunavajo le, če se pritožba zavrne. Ta zapis sicer ne moti, ampak ni potreben, kajti obresti so akcesorna terjatev in če glavnica ne obstaja, tudi obresti ne nastanejo.

Poenostavljeno napisano davčni organ pri odlogih in obročnih plačilih, s tem ko odloči, da zavezancu davka določen čas ni treba plačati, na nek način zavezancu posodi količino denarja, ki bi ga je dolžan državi in bi ga moral tudi že plačati, če mu odlog ali obročno plačilo ne bi bila odobrena. ${ }^{20} \mathrm{~V}$ ta namen mu »zaračuna« obresti, ki v tem primeru ne morejo predstavljati drugega kot nadomestilo za uporabo denarja, kar je osnovna funkcija obresti. Kakršnakoli drugačna funkcija obresti bi bila sporna $z$ vidika ustavnosodne prakse (odločba Ustavnega sodišča U-I-233/01 z dne 5. 2. 2004). Zaradi poenostavitve ${ }^{21}$ je zakonodajalec predpisal enotno obrestno mero, saj je tako delo davčnega organa enostavnejše, kot je bilo pred tem, ko je moral davčni organ ugotavljati, koliko na določen dan znaša letna evropska (še prej pa slovenska) medbančna obrestna mera. Izhajajoč iz te ugotovitve, lahko sklenemo, da ostale obrestne mere, ki presegajo 2 odstotka (oziroma referenčno obrestno mero za izračun državne pomoči) letno, poleg nadomestila za uporabo denarja, vključujejo tudi določen pribitek, katerega namen je spodbuditi zavezance, naj čim prej izpolnijo svojo davčno obveznost.

\footnotetext{
${ }^{20}$ Sporna pa se zdita vsebini tretjega in četrtega odstavka 87. člena ZDavP-2, po katerih se obresti obračunajo za čas odložitve izvršbe. Če namreč zavezanec plača, čeprav mu je izvršba odložena, potem davčni organ ne bi smel zaračunati obresti. Odlog pomeni zgolj prestavitev paricijskega roka, ne pomeni pa, da zavezanec ne bi bil upravičen plačati pred potekom, sploh če zavezanec za odlog sploh ne bi zaprosil, saj bi šlo v takem primeru za prisilno obrestovano posojilo. Tudi prvi odstavek 99. člena ZDavP-2 denimo določa, da gredo obresti za preveč ali neupravičeno odmerjen davek od dne dejanskega plačila davka in ne od dne, ko bi ga zavezanec moral plačati glede na paricijski rok.

21 Enako stališče zagovarja nemška davčna teorija (Helmschrott, Schaeberle, \& Scheel, 2016). Tudi v Zvezni republiki Nemčiji je predpisana fiksna obrestna mera, ki ni odvisna od vsakokratnih razmer na trgu. Znaša 0,5 odstotka mesečno in naj tudi v obdobjih nizkih tržnih obrestnih mer po presoji Zveznega finančnega sodišča ne bi pomenila neustavnosti.
} 


\subsection{Obresti pri predložitvi obračuna ali napovedi po izteku predpisanega roka ( 0 odstotkov letno)}

ZDavP-2 pri preložitvi obračuna davka po izteku roka (52. in šesti odstavek 57. člena) ter pri vložitvi davčne napovedi po izteku predpisanega roka (62. člen) določa, da se ti dve vlogi štejeta za pravočasno vloženi, če je zamuda posledica opravičljivih razlogov. Ti so podani, kadar so nastale okoliščine, ki jih zavezanec ni mogel predvideti oziroma odvrniti in preprečujejo pravočasno vložitev vloge. Zavezanec lahko predlog za odobritev vložitve poda v 8-dnevnem subjektivnem in 3-mesečnem objektivnem roku. Institut je zelo podoben splošnemu institutu vrnitve $\mathrm{v}$ prejšnje stanje, le da gre $\mathrm{v}$ tem primeru za opravičilo zamude materialnega roka, česar z vrnitvijo v prejšnje stanje ni mogoče doseči, saj velja le za procesne roke (Kerševan \& Androjna, 2017). V tem primeru zavezanca ne bremenijo obresti, saj mora glede na zakonsko določbo plačati le davek (glavnico), in sicer hkrati s predložitvijo obračuna, čeprav je obračun vložen po zapadlosti davčne obveznosti. ${ }^{22}$

\footnotetext{
22 Zapadlost davčne obveznosti po pravilih iz ZDavP-2 je odvisna od vrste izvršilnega naslova. Pri obračunih davka (davčni obračun in obračun davčnega odtegljaja) je predpisano, da mora biti davek plačan $\mathrm{v}$ rokih, predpisanih z zakonom (56. in 60. člen ZDavP-2), pri odmernih odločbah pa je ta rok 30 dni od vročitve odločbe, če ni predpisano drugače (sodba Vrhovnega sodišča X Ips 179/2013). Določitev zapadlosti pri odmernih odločbah ni problematična, tega pa ni mogoče trditi za obračune davka. Zakonodajalec je namreč uporabil dva načina, s katerima je predpisal zapadlost, in sicer fiksno (neodvisno od vložitve obračuna) in $\mathrm{v}$ odvisnosti od predložitve obračuna (predpisano je, da je zavezanec dolžan izpolniti obveznost v določenem roku po vložitvi obračuna). Kadar je zapadlost določena fiksno (npr. pri davku na dodano vrednost), ni težav, kadar pa je predpisana v odvisnosti od predložitve obračuna (npr. pri davku od dohodkov pravnih oseb), se zastavlja vprašanje, ali ima opustitev predložitve obračuna za posledico, da obveznost sploh ni zapadla. Teorija (Jerovšek, in drugi, 2008) meni, da v tem primeru zapadlost nastopi neodvisno od dejanskega obračuna, torej ko bo zapadla obveznost, če bi bila pravilno obračunana. Zdi se, da je enako tudi stališče Ustavnega sodišča, ki je v odločbi U-I-356/02 z dne 23. 9. 2004 zapisalo: »Vendar [...] ni mogoče spregledati primerov, ko davčni organ obveznost davčnega zavezanca ugotovi in z odločbo naloži šele po tem, ko je predpisani rok za plačilo že potekel.«

Pomembno je opozoriti še na izpolnitveni oziroma paricijski rok, ki ga je treba ločiti od roka zapadlosti (dospelosti). Gre za »rok, v katerem je zavezana stranka dolžna izpolniti obveznost, naloženo z upravno odločbo ali drugim izvršilnim naslovom v upravnem postopku, in katerega potek je procesna predpostavka za začetek izvršbe« (Accetto, in drugi, 2018). Lahko je torej dospelost že nastopila, ni pa še nastopil rok, v katerem je treba izpolniti obveznost, ker denimo obveznost še ugotovljena v izvršilnem naslovu (odločba ali obračun davka). Če vpeljemo v razlago še paricijski rok, je Ustavno sodišče v zgoraj citirani odločbi zapisalo, da zamudne obresti ne morejo teči pred potekom tega roka.
} 


\subsection{Obresti pri samoprijavah (3 odstotke letno)}

ZDavP-2 ureja dve obliki samoprijave, in sicer predložitev davčnega obračuna na podlagi samoprijave (55. člen) in vložitev davčne napovedi na podlagi samoprijave (63. člen). Ureditev, ki velja za davčni obračun na podlagi samoprijave, se uporablja tudi za obračun davčnega odtegljaja na podlagi samoprijave (šesti odstavek 57. člena). ${ }^{23}$ Obračun in napoved sta sicer posebni obliki napovedovanja oziroma obračunavanja davkov, ki sta vloženi po izteku roka, ki pa se vsebinsko ne razlikujeta od pravočasno oddanih vlog (sklep Vrhovnega sodišča X Ips 63/2017 z dne 6. 7. 2017). Namen samoprijave je spodbuditi zavezance, da davčnemu organu sporočijo nastanek davčne obveznosti, ki jo iz kakršnegakoli razloga prej niso prijavili ali pa so to storili le delno (Jerovšek, in drugi, 2008). Zavezanci, ki so se odločili za samoprijavo, so za njeno vložitev "nagrajeni« na način, da niso kaznovani za storjeni prekršek (Podlipnik, 2011), po prej veljavni ureditvi pa so morali plačati medbančne obresti, ki so bile povečane za kazenske penale oziroma pribitke (Jerovšek, in drugi, 2008), ki so se povečevali glede na pretečeni čas od poteka roka do dejanske vložitve samoprijave, kar je že bilo napisano zgoraj.

Z novelo ZDavP-2J se je ureditev, ki se tiče obresti, spremenila na način, da je predpisana enotna obrestna mera, katere višina ni (več) odvisna od časa, ki preteče od poteka roka za vložitev davčne napovedi ali obračuna davka do vložitve davčne napovedi ali obračuna davka na podlagi samoprijave. Tako bodo tisti, ki vložijo samoprijavo, pozneje sicer plačali absolutno več obresti, ker bo vmes minilo več časa, ne bodo pa plačali tudi relativno več obresti, kot je veljalo do novele. $\mathrm{S}$ tem se je sistem administrativno poenostavil. Pribitek glede na obresti, ki predstavljajo nadomestilo za uporabo denarja (2 odstotka letno), znaša v primeru samoprijave odstotno točko (obresti so višje za 50 odstotkov). V primerjavi z ostalimi je ta pribitek še najnižji, iz česar je mogoče sklepati, da se želi z njegovo višino zavezance spodbuditi, da izvedejo samoprijavo in ne čakajo, da davčno obveznost odmeri davčni organ brez njihovega sodelovanja.

\footnotetext{
${ }^{23}$ Ta ureditev je splošna, kar pomeni, da velja za vse davke, če ni drugače predpisano. Drugačna je bila denimo ureditev na področju davka na dodano vrednost (DDV), kjer je zakonodajalec do 1. januarja 2019 ohranil sistem medbančnih obresti in pribitkov nanje (Špilar, 2018). Zdi se, da to ni bilo storjeno namenoma, ampak zaradi nedoslednosti. Po takratni je bilo lahko za zavezanca na področju DDV v določenih okoliščinah (v primeru visokih medbančnih obrestnih mer in pribitkov) celo ugodneje, če je počakal na odmero davka, kot če bi se samoprijavil. To pa gotovo ni mogel biti zakonodajalčev cilj. Z novelo ZDDV-1J (Uradni list RS, 77/2018), ki se je začela uporabljati 1. januarja 2019, je zakonodajalec uskladil obrestne mere za samoprijavo v Zakonu o davku na dodano vrednost (ZDDV-1), Uradni list RS, št. 13/11 - uradno prečiščeno besedilo, 18/2011, $78 / 2011,38 / 2012,83 / 2012$, 86/2014, 90/2015 in 77/2018, s tistimi po ZDavP-2, pri čemer pa ni previdel nobenega prehodnega obdobja za obresti, ki so se natekle do uveljavitve novele.
} 


\subsection{Obresti pri napovedih po izteku roka brez opravičenih razlogov (3 odstotke letno)}

Enako višino obresti kot pri samoprijavi je zakonodajalec predpisal tudi $\mathrm{v}$ primerih, ko davčni zavezanec naknadno predloži davčno napoved, ne da bi izpolnil pogoje za eno od posebnih oblik napovedi, urejenih v 62. in 63. členu ZDavP-2. Položaj ureja deveti odstavek 62. člena ZDavP-2, ki določa, da kadar davčni organ ne dovoli predložitve davčne napovedi po izteku predpisanega roka, se za čas od poteka roka za vložitev davčne napovedi do vložitve davčne napovedi obračuna obresti po obrestni meri, ki znaša 3 odstotke letno. Čeprav je določba del posebne oblike davčne napovedi po izteku predpisanega roka, ni razloga, zakaj je ne bi mogli uporabiti tudi za primere, ko bi davčni zavezanec naknadno vložil napoved, ne da bi sploh opravičeval zamudo ali ko bi zamudil rok za vložitev davčne napovedi po izteku predpisanega roka in se ne bi odločil za vložitev davčne napovedi na podlagi samoprijave. Je pa vložitev samoprijave vseeno ugodnejša za zavezanca, kajti v takem primeru je zavezanec še vedno lahko kaznovan za prekršek. Ureditev se ne zdi logična, saj je lahko zavezanec kaznovan, čeprav je sam napovedal svoje davčne obveznosti oziroma se mu to lahko zgodi celo, ker je izbral napačno procesno pot, saj je zmotno menil, da izpolnjuje pogoje po 62. členu ZDavP-2, če pa bi vložil davčno napoved po 63. členu ZDavP-2, bi se izognil sankciji za prekršek. Davčni organ je zaradi vložene napovedi, čeprav je ta vložena naknadno, še vedno na boljšem, saj bo zavezancu lahko odmeril davek (in obresti) po izvedbi skrajšanega ugotovitvenega postopka (drugi odstavek 73. člena ZDavP-2).

\subsection{Obresti pri obračunih $\mathrm{v}$ postopkih davčnega inšpekcijskega nadzora (5 odstotkov letno)}

Z novelo ZDavP-2J je zakonodajalec v ZDavP-2 vnesel 140.a člen, ki je tistim, ki niso vložili obračuna davka, omogočil, da to storijo tudi še po tem, ko so že prejeli zapisnik $\mathrm{v}$ postopku davčnega inšpekcijskega nadzora. To lahko zavezanci storijo, dokler ne poteče 20-dnevni zakonski rok za vložitev pripomb na zapisnik. Ker davčnemu organu ni treba sestaviti in vročiti odmerne odločbe, saj je zavezanec kršitev odpravil sam, je zavezanec »nagrajen« z nižjo (5-odstotno) obrestno mero $\mathrm{v}$ primerjavi z obrestno mero, ki bi jim bila odmerjena $\mathrm{v}$ postopku 
nadzora za isto obdobje (7 odstotkov letno). ${ }^{24} \mathrm{Na}$ ta način se spodbuja tiste, ki ne morejo več vložiti obračuna davka na podlagi samoprijave, da podobno storijo naknadno, za nekoliko višje obresti in brez kaznovanja za prekršek (399. člen ZDavP-2). Pribitek na obresti, ki tečejo od poteka roka za plačilo davka do predložitve davčnega obračuna oziroma popravljenega davčnega obračuna, je torej tri odstotne točke nad obrestno mero, ki pomeni nadomestilo za uporabo denarja. Gre torej za 150 odstotni pribitek, ki pomeni spodbudo, da bi zavezanci že $\mathrm{v}$ osnovi obračunali in plačali pravilne zneske davka oziroma bi to storili vsaj pred začetkom inšpekcijskega postopka z vložitvijo obračuna davka na podlagi samoprijave.

\subsection{Obresti v postopkih davčnega nadzora (7 odstotkov letno)}

Zavezanci, ki jim davčni organ $\mathrm{v}$ enem od postopkov davčnega nadzora (postopek nadzora obračunov, postopek nadzora posameznega področja poslovanja in postopek davčnega inšpekcijskega nadzora) odmeri davek, so dolžni na podlagi 95. člena ZDavP-2 poleg glavnice (davek) plačati tudi obresti, ki trenutno znašajo 7 odstotkov letno. Te obresti tečejo od poteka roka za plačilo davka oziroma od poteka roka za vložitev davčne napovedi oziroma od dneva neupravičeno vrnjenega davka, iz razlogov, ki so na strani zavezanca, do izdaje odločbe. Kot je bilo že navedeno, je bila ta kategorija obresti uvedena zaradi odločbe Ustavnega sodišča (U-I-356/02 z dne 23. 9. 2004), ki je zavzelo stališče, da lahko zamudne obresti tečejo šele od izvršljivosti (zamude) dalje, v času zapadlosti, ko še ni nastopila izvršljivost (zamuda), pa bi lahko tekle drugačne (nezamudne) obresti. V prvi fazi je zakonodajalec uvedel medbančno obrestno mer, ki je predstavljala uporabnino, z novelo ZDavP-2J pa je višino te obrestne mere precej približal obrestni meri zamudnih obresti, saj je pribitek na obrestno mero, ki predstavlja uporabnino, precejšen (5 odstotnih točk oziroma 250 odstotkov).

\footnotetext{
${ }^{24} \mathrm{~S}$ stališča načela enakosti pred zakonom je vprašljiva ureditev, ki »skesanje« za nižje obresti in nekaznovanje za prekršek, omogoča le tistim zavezancem, ki davke obračunavajo, ne pa tudi tistim, ki davke napovedujejo. Tako je izključno od načina izračuna davka, kar je nekaj, kar po lastni presoji predpiše zakonodajalec, odvisno, ali lahko zavezanec izkoristi ugodnosti. Ker je vložitev »običajne« samoprijave na smiselno enak način omogočena za obe obliki izvršilnih naslovov, ni jasno, zakaj ne velja enako tudi za »samoprijavo«v postopkih davčnega inšpekcijskega nadzora. Čeprav so v bistveno enakih pravnih položajih, davčna zakonodaja po začetku davčnega inšpekcijskega nadzora ugodneje obravnava tiste, ki so dolžni davek obračunati v primerjavi s tistimi, ki ga »zgolj« napovedujejo.
} 


\subsection{Obresti v primeru pomanjkljivosti in pomot $\mathrm{v}$ davčnem obračunu ( 9 odstotkov letno)}

V 53. členu ZDavP-2 je urejena posebna oblika obračuna, ki se uporablja tudi za potrebe obračunov davčnega odtegljaja (šesti odstavek 57. člena ZDavP-2), po kateri lahko zavezanec v 60 dneh po predložitvi obračuna predloži popravek obračuna, če je prvotni obračun, ki ga je predložil, vsebuje formalne pomanjkljivosti oziroma pomote $\mathrm{v}$ imenih in številkah ali pisne oziroma računske pomote. Za vprašanje obresti je pomemben četrti odstavek 53. člena ZDavP-2, ki določa, da razlika $\mathrm{v}$ davčni obveznosti med predloženim in popravljenim obračunom učinkuje od dneva, od katerega je učinkoval obračun, ki se popravlja, če zavezanec $v$ popravljenem obračunu poveča davčno obveznost. Predpisano je torej, da popravljeni obračun učinkuje retroaktivno (ex tunc). To ima za posledico, da je zavezanec lahko ob oddaji popravljenega obračuna že $v$ zamudi $z$ izpolnitvijo, zaradi česar nastopijo posledice zamude $\mathrm{v}$ obliki zamudnih obresti. Te obresti tečejo od zapadlosti prvotnega obračuna do izpolnitve (plačila) obveznosti, ne pa denimo do vložitve popravljenega obračuna, kot velja večinoma pri naknadno popravljenih obračunih (npr. samoprijava).

\subsection{Obresti pri prepoznih obračunih, ki niso samoprijava (9 odstotkov letno)}

Z novelo ZDavP-2F je zakonodajalec v pravni red vnesel 95. a člen ZDavP-2, po katerem se v primerih, ko ne gre za predložitev obračuna na podlagi samoprijave (55. člen ZDavP-2), in zavezanec predloži obračun davka ali popravek obračuna davka po izteku zakonskega roka, za čas od poteka roka za plačilo davka do plačila davka obračunajo obresti 9-odstotni letni obrestni meri (96. člen ZDavP2). Določba ureja obračunavanje obresti, ko zavezanci ne bi vložili katerega od posebnih oblik obračunov, ampak bi naknadno vložili »običajen« obračun oziroma bi brez izpolnjevanja pogojev vložili kakšno posebno obliko obračuna (npr. vložili bi obračun na podlagi samoprijave, vendar ne bi hkrati plačali davka in obresti). Tudi v tem primeru, enako kot velja za prejšnjega, obresti tečejo do izpolnitve (plačila) obveznosti, ne do vložitve te oblike obračuna. 


\subsection{Zamudne obresti (9 odstotkov letno)}

V 96. členu ZDavP-2 je predpisano, da mora zavezanec od davkov, ki jih ni plačal v predpisanem roku, plačati zamudne obresti po 0,0247 odstotni dnevni obrestni meri, kar preračunano pomeni 9-odstotno letno obrestno mero. Čeprav to ni izrecno navedeno, pa je iz smisla zamudnih obresti mogoče ugotoviti, da te tečejo ves čas trajanja zamude, torej od njenega nastanka do prenehanja (npr. z izpolnitvijo, prenehanjem, odlogom plačila). Zamudne obresti ne tečejo od zamudnih obresti, lahko pa tečejo od nekaterih drugih vrst obresti.

Definicija davčnih zamudnih obresti se od leta 1997 ni spreminjala, kajti današnja je bolj ali manj identična definiciji v ZDavP (100. člen) in ZDavP-1 (prvi odstavek 31. člena), kar ni dobro, saj definicija ni najbolj natančna. Ni namreč jasno, ali ima zakonodajalec pod pojmom "predpisani rok« v mislih rok zapadlosti (dospelosti) ali izpolnitveni (paricijski) rok. Glede na vsebino odločbe Ustavnega sodišča (U-I-356/02 z dne 23. 9. 2004) je lahko mišljen le izpolnitveni (paricijski) rok, saj lahko te obresti tečejo šele od zamude dalje. Zamuda namreč nastopi »šele« z izvršljivostjo, ne pa že z zapadlostjo. Priporočljivo bi bilo, če bi zakonodajalec definicijo zamudnih obresti prilagodil, za zgled pa mu je lahko definicija zamudnih obresti iz 378. člena OZ. Tako bi se denimo definicija lahko glasila: »Če je zavezanec za davek v zamudi z izpolnitvijo davka, ki nastopi z izvršljivostjo, dolguje poleg glavnice še zamudne obresti, katerih dnevna obrestna mera znaša 0,0247 odstotka.« Sedanja definicija pri nekaterih uporabnikih povzroča zmedo, kajti še vedno uporabljajo pojem zamude in zamudnih obresti, čeprav gre »zgolj« za plačilo po zapadlosti, ko zamuda še ni nastopila, saj izvršilni naslov še ni postal izvršljiv, zato bi jo veljalo spremeniti v eni od prihodnjih zakonskih novel. 


\section{Analiza ureditve in nekaterih njenih »nenavadnih« rešitev}

\subsection{Splošno}

$\mathrm{V}$ tej točki so predstavljene nekatere nenavadne zakonske rešitve $\mathrm{v}$ sistemu davčnih obresti po noveli ZDavP-2J, ki je bila opisana v prejšnji točki. Namen, ki ga je zakonodajalec zasledoval pri obrestih s pribitkom zaradi nespoštovanja davčnih predpisov, je razviden iz predloga novele, ${ }^{25}$ kjer je navedeno: »Pri določitvi obresti $\mathrm{v}$ zvezi $\mathrm{z}$ nespoštovanjem predpisov pri vložitvi davčne napovedi in predložitvi davčnega obračuna se upoštevata teža kršitve in okoliščina, ali je davčni zavezanec kršitev odpravil sam ali pa je kršitev ugotovil davčni organ. [...] S predlagano določitvijo obresti se odpravi nesorazmerje $\mathrm{v}$ zvezi s plačilom obveznosti glede na težo kršitve, kar zagotavlja davčno pravičnost. [...] Z določitvijo predlagane višine obresti, ki se povečujejo glede na težo kršitve in okoliščine, ali je davčni zavezanec kršitev odpravil sam ali pa je kršitev ugotovil davčni organ, se želi spodbuditi davčne zavezance k pravilnemu in pravočasnemu izpolnjevanju davčne obveznosti.« Davčni organ v tem delu tudi predstavi ureditev, torej višino obrestnih mer od 3 do 9 odstotkov letno.

V zvezi z zapisanim velja opozoriti na nekatere nedoslednosti $\mathrm{v}$ zapisu. Za napačno uporabo izrazoslovja gre, ker predlagatelj uporablja pojem davčni zavezanec, kajti navedeno lahko velja za vse zavezance za davek, ne la za davčne zavezance. Poleg tega predlagatelj najbrž nima $v$ mislih, da je višina obresti odvisna od teže kršitve in dejstva, ali je kršitev odpravil zavezanec sam, ampak da je od teh dveh okoliščin odvisna višina obrestne mere. Obrestna mera je le eden od elementov (poleg glavnice in časa), ki opredeljuje, koliko obresti bo treba plačati. Ker je predlagatelj analiziral le višino obrestnih mer, ne pa tudi ostalih elementov, je mogoče sklepati, da napačno piše o obrestih, saj ima v mislih obrestne mere. Tudi podatek, da na višino obrestne mere vpliva okoliščina, da je kršitev ugotovil davčni organ, je verjetno napačna, kajti edino logično je, da bi pisalo, da je kršitev odpravil (ne zgolj ugotovil) davčni organ, kajti denimo pri obračunu v postopku davčnega inšpekcijskega nadzora davčni organ za kršitev ve, saj jo je obravnaval v zapisniku, zavezancu pa omogoči plačilo obresti po nižji obrestni meri, če kršitev odpravi sam.

${ }^{25}$ Predlog Zakona o spremembah in dopolnitvah Zakona o davčnem postopku, EVA: 2016-1611-0003 z dne 7. 9. 2016. 
Pravilnost navedbe, da na višino obrestne mere vpliva teža kršitve, se ne zdi pravilna, oziroma iz zapisanega ni jasno, od kod to izhaja. Teže kršitve davčne zakonodaje namreč davčni organ sploh ne ugotavlja in posledično temu ne prilagaja višine obrestne mere. Tudi način, na katerega je zakonodajalec predpisal višine obrestnih mer, ne odražajo teže kršitev davčne zakonodaje. Ne nek način teža kršitev davčne zakonodaje vpliva na znesek obresti (ne na obrestno mero). Če je namreč davčna obveznost, ki je zavezanec ni obračunal ali napovedal, nižja, potem bo nižji tudi znesek obračunanih obresti od te glavnice in obratno. Da bi bila višina obrestne mere odvisna od teže kršitve, bi moral zakonodajalec denimo predpisati višje obrestne mere za višje zneske in nižje obrestne mere za nižje zneske ali pa bi po zgledu glob za prekrške predpisal višje obresti, kadar bi zavezanec vložil napačno napoved (1. točka 394. člena ZDavP-2), kot če davčne napovedi sploh ne bi vložil (1. točka 395. člena ZDavP-2). Takega razlikovanja pa ureditev ne vsebuje.

Iz pravkar zapisanega je mogoče ugotoviti, da je višina obrestne mere (pribitka na uporabnino za uporabo denarja) torej odvisna izključno od okoliščine, ali zavezanec kršitev odpravi sam z vložitvijo pravilnega obračuna ali davčne napovedi ali pa mora kršitev odpraviti davčni organ. Namen zakonskih določb o višini obrestne mere je torej lahko zgolj v tem, da »spodbudijo« zavezance, naj ugotovljene kršitve čim prej odpravijo sami, saj jim bo sicer davčni organ "zaračunal dodatno delo za izvajanje postopkov« $\mathrm{v}$ obliki višjih pribitkov na obrestno mero, ki predstavlja uporabnino za denar (2 odstotka).

\subsection{Različne obrestne mere za isti dejanski stan $\mathrm{v}$ odvisnosti od kasnejšega zavezančevega ravnanja}

Iz predstavljene ureditve izhaja, da je ZDavP-2 za različne položaje predpisal nastanek različnih pravnih posledic. $\mathrm{S}$ tem ni $\mathrm{v}$ osnovni nič narobe, toda $\mathrm{ob}$ začetku teka obresti ni mogoče predvideti, po kateri obrestni meri bodo tekle obresti, saj je to izključno odvisno od tega, kako kasneje ravna zavezanec za davek. Primerjava vsebine določb, ki urejajo vprašanje teka obresti, kadar mora zavezanec davke obračunati (55., 95., 95.a in 140.a člen ZDavP-2), pokaže, da obresti tečejo od poteka roka za plačilo, ${ }^{26}$ kadar pa mora zavezanec davke »zgolj« napovedati (62., 63. in 95. člen ZDavP-2), tečejo obresti od poteka roka za

\footnotetext{
${ }^{26}$ Enako določba pravzaprav tudi 96. člen ZDavP-2, ki ureja zamudne obresti, toda ta definicija je nenatančna, kar je že bilo pojasnjeno.
} 
vložitev napovedi. ${ }^{27} \mathrm{Ni}$ jasno, kako lahko v primeru opustitve predložitve (pravilnega) obračuna oziroma opustitve vložitve (pravilne) napovedi ob enakem dejanskem stanju začnejo teči obresti po različnih obrestnih merah, ki so odvisne od okoliščin, ki takrat še niso nastopile, ampak nastanejo pozneje. Obresti tečejo avtomatično (neposredno na podlagi zakona), ko je izpolnjen zakonski dejanski stan, zato lahko ob enakih okoliščinah (premalo obračunan ali napovedan davek) tekle obresti po enotni obrestni meri, pa naj bo ta v višini nadomestila za uporabo denarja ali pa takega nadomestila s kaznovalnim pribitkom. ZDavP-2 predpisuje, da se višina obrestne mere, po kateri se obrestuje glavnica zavezanca, oblikuje šele naknadno, in sicer glede na to, kako sam ravna po trenutku, ko so obresti začele teči. Zdi se, da pribitki na 2-odstotno obrestno mero, ki pomeni nadomestilo za uporabo denarja, po vsebini ne morejo predstavljati obresti, ki bi začele teči že s tem, ko se izpolni zakonski dejanski stan, temveč so pribitki po vsebini (administrativne) sankcije, ki pa se trenutno izrekajo v obliki obresti. Ni primerno, da obresti predstavljajo sankcioniranje za nespoštovanje administrativnih obveznosti (Gordon, 1996), ampak pomenijo nadomestilo za uporabo denarja, pri čemer je priporočljivo, da so obrestne mere višje od tržnih obrestnih mer, saj se s tem odvrača zavezance, da bi si denar »izposojali« od države. Sankcija v višini pribitka je tako lahko le posledica nepravočasnega plačila, ne pa nepravočasnega ali napačnega poročanja. Temu so namenjene druge sankcije.

\subsection{Različne obrestne mere, ko se zavezanec tekom postopka odloči, da bo sam obračunal davke}

Sporna se zdi sporna ureditev, po kateri znaša obrestna mera v primeru vložitve obračuna davka na podlagi samoprijave, ki jo je mogoče izvesti do izdaje odločbe (v postopku nadzora obračunov ali v postopku nadzora posameznega področja poslovanja) 3 odstotke letno, obrestna mera pri predložitvi obračuna davka $\mathrm{v}$ postopku davčnega inšpekcijskega nadzora pa znaša 5 odstotkov letno. Zavezanec, zoper katerega tečeta postopek davčnega nadzora obračunov (129. člen ZDavP-2) ali postopek nadzora posameznega področja poslovanja (130. člen ZDavP-2), lahko še tudi po prejemu zapisnika, toda pred izdajo odločbe vloži obračun davka na podlagi samoprijave in bo $\mathrm{v}$ tem primeru, čeprav je postopek tik pred izdajo odločbe, upravičen do obrestovanja po nižji obrestni

\footnotetext{
${ }^{27}$ To je samo po sebi problematično, vendar je obravnavano pozneje.
} 
meri kot zavezanec, zoper katerega teče postopek davčnega inšpekcijskega nadzora. $V$ vseh treh primerih nadzorov gre za postopke davčnega nadzora (127. člen ZDavP-2), ki si se razlikujejo predvsem po zahtevnosti, pri čemer se postopek davčnega inšpekcijskega nadzora lahko začne neposredno ali pa "preko« katerega od ostalih dveh postopkov nadzora (sedmi odstavek 129. člena ZDavP-2 in šesti odstavek 130. člena ZDavP-2). Višina obrestne mere $v$ tem primeru torej ni odvisna le od želje zavezanca, da sam popravi napačen obračun, ampak tudi od tega, katerega od postopkov nadzora uvede davčni organ, to pa ni v skladu z deklariranim namenom zakonodajalca in po praksi Ustavnega sodišča (odločba Up-492/11 z dne 9. 5. 2013) vprašljivo z vidika načela enakosti pred zakonom iz drugega odstavka 14. člena Ustave.

\subsection{Začetek teka obresti, preden bi sploh teoretično lahko nastopila zapadlost}

Kot je že bilo navedeno, davčne obveznosti, ki jih je treba obračunati, zapadejo $\mathrm{v}$ plačilo, ko so izpolnjeni zakonski pogoji, in sicer neodvisno od tega, ali so zavezanci te obveznosti tudi izračunali. Neodvisno od poteka paricijskega roka torej. Zdi se, da ZDavP-2 začetek teka obresti veže na zapadlost. Na paricijo gotovo ne, kajti takrat že tečejo zamudne obresti. Nekoliko drugače velja za davčne obveznosti, ki jih davčni organi odmerjajo z odločbami na podlagi napovedi. ZDavP-2 $\mathrm{v}$ takih primerih določa, da začnejo obresti teči od poteka roka za vložitev davčne napovedi, kar je problematično. S potekom roka za vložitev davčne napovedi davčna obveznost namreč še ne zapade v plačilo, saj mora biti o tem šele izdana odločba (66. člen ZDavP-2). Z (dejansko) vložitvijo napovedi začne za davčni organ teči (instrukcijski) rok za izdajo odmerne odločbe, ki običajno znaša 30 dni. Ta odločba mora biti vročena zavezancu, in sicer običajno z navadno vročitvijo, kar pomeni, da se šteje, da je vročitev opravljena petnajsti dan od datuma odpreme (85. člen ZDavP-2). Po vročitvi pa ima zavezanec praviloma 30 dni, da plača davek (66. člen ZDavP-2). Če dejanski roki niso znani (npr. ko je zavezancu bila izdana odločba, vendar za prenizek znesek), bi zakonodajalec pri določitvi teoretično možnega roka zapadlosti moral upoštevati roke, ki jih predpisuje zakon. To bi lahko storil denimo s zakonskim določilom (klavzulo), da obresti tečejo od dneva, po katerem bi potekel rok za plačilo, če bi zavezanec vložil napoved zadnji dan in ob upoštevanju najdaljših rokov za izdajo odločbe, njeno vročitev in plačilo davka. $Z$ vidika načela enakosti so zavezanci, ki so davke dolžni obračunati, v boljšem položaju od zavezancev, ki so dolžni zgolj vložiti napoved. Prvi bodo namreč dolžni plačati obresti od 
dejanske zapadlosti davčne obveznosti, drugi pa že pred datumom, ko bi ta obveznost lahko tudi teoretično zapadla $\mathrm{v}$ plačilo. Zakonska rešitev ni skladna $\mathrm{z}$ duhom odločbe Ustavnega sodišča U-I-356/02 z dne 23. 9. 2004, saj je iz nje mogoče razbrati, da se lahko zavezancu obresti naložijo v plačilo od zapadlosti dalje, ne pa pred tem.

\subsection{Zamudne obresti, ki tečejo pred nastankom zamude (izvršljivosti)}

Iz 53. in 95.a člena ZDavP-2 izhaja, da so zavezanci dolžni plačati obresti v višini 9 odstotkov letno tudi za obdobje pred nastankom zamude, ta pa nastopi hkrati z izvršljivostjo. Zdi se, da je to v nasprotju s smislom odločbe Ustavnega sodišča U-I-356/02 z dne 23. 9. 2004. Res je sodišče v tej odločbi obravnavalo primere, ko je davek naknadno odmeril davčni organ, kajti takratna procesna davčna zakonodaja ni vsebovala institutov, ki bi omogočali obračun davka po izteku predpisanih rokov, zato je bil davčni organ tisti, ki je gospodaril z obsegom finančnega bremena zavezanca. Se pa postavlja vprašanje, ali ne bi Ustavno sodišče zavzelo enakega stališča tudi za primere, ko zavezanci sami popravijo napačne obračune oziroma vložijo obračune, ki jih pred tem niso.

Po drugi strani pa se zdi, da sta 53. in 95.a člen ZDavP-2 v nasprotju z namenom, ki ga je glede obresti predlagatelj navedel v noveli ZDavP-2J. Če je naj bi bila namreč višina obrestne mere odvisna od dejstva, ali je zavezanec kršitev odpravil sam in tega ni prepustil davčnemu organu, ni jasno, zakaj bi potem v dveh primerih veljalo ravno obratno. Zavezanec torej predloži obračun in s tem sanira svojo napako, kljub temu pa mora (za nazaj) plačati obresti v višini zamudnih obresti. Rešitev je torej $\mathrm{v}$ nasprotju s ciljem, ki ga je zasledoval predlagatelj novele. $^{28}$

Še več. Če zavezanec popravi napako ko davčni organ že izvaja davčni inšpekcijski postopek (140.a člen ZDavP-2) ali celo če sploh ne popravi svoje napake, ampak to delo prepusti davčnemu organu (95. člen ZDavP-2), bo za isto obdobje, ko bi napako popravil, dolžan plačati celo obresti po nižji obrestni meri, kajti 140.a in 95. člen ZDavP-2 predpisujeta 5- oziroma 7-odstotne letne obresti. Čeprav ni sporno, da se bo teh obresti v primeru izvajanja postopka davčnega

\footnotetext{
${ }^{28}$ Omeniti velja, da je nenavadna zakonska rešitev, da se zavezancu, ki vloži obračun po 95.a členu ZDavP-2, obračunajo obresti po 9-odstotni letni obrestni meri, obenem pa ni »nagrajen« z opustitvijo prekrškovne globe, ker taka zakonodajna rešitev ne spodbuja zavezancev, da bi sami popravljali napačne obračune oziroma vlagali obračunov, ki jih niso vložili, kar naj bi bil cilj zakonodajalca.
} 
nadzora nabralo več, saj bodo obresti tekle dalj časa, je težko razumeti cilj, ki ga je s tako ureditvijo zasledoval predlagatelj. Gotovo pa na ta način ni dosegel cilja, ki naj bi ga po lastnih navedbah želel doseči (tj. spodbuditi zavezance, da napake odpravijo sami).

Podoben zaključek je za vsebino 53. člena ZDavP-2 mogoče narediti še v enem primeru. Če zavezanec v relativno kratkih rokih opraviči očitno napako, ga za nazaj bremenijo obresti v višini zamudnih obresti. Če pa po drugi strani vloži obračun davka na podlagi samoprijave, kjer mu ni treba pojasnjevati razlogov za popravek, ampak je lahko celo namenoma napačno obračunal davek, ga za isto obdobje bremenijo »zgolj« obresti v višini 3 odstotkov letno. Čeprav predlagatelj novele ZDavP-2J ne omenja, da bi oblika krivde (malomarnost ali naklep) vplivala na višino obrestne mere, pa je kljub temu nenavadno, da je očitna napaka (malomarnost) $\mathrm{z}$ vidika višine obrestne mere obravnavana strožje kot možen naklep. ${ }^{29}$

\subsection{Opustitev vložitve napovedi in obresti}

Obresti v višini 7 odstotkov letno so skladno s 95. členom ZDavP-2 dolžni plačati le tisti zavezanci, ki jim je davek odmerjen v eni od oblik postopkov davčnega nadzora. Če je denimo davčna napoved napačna, vendar pa se to ugotovi že pred izdajo odločbe ali pa se to ugotovi pozneje ter se že izdana odločba odpravi s pravnimi sredstvi in kasneje se (npr. v obnovljenem postopku) izda nova odločba v postopku, ki ni postopek nadzora, davčni organ obresti ne obračuna. Čeprav gre za bistveno enak položaj (napačna napoved), pa so pravne posledice različne, in sicer je od odločitve davčnega organa odvisno, ali bo davek odmeril v postopku nadzora ali ne. Da je taka ureditev lahko problematična z vidika načela enakosti pred zakonom, je Ustavno sodišče že odločilo (odločba

\footnotetext{
${ }^{29} \mathrm{Ob}$ tem se tako ali tako zastavlja vprašanje smiselnosti vseh možnih oblik popravkov obračunov. V pravu običajno velja, da mora obstajati (jasna) ločnica med tem, kdaj je mogoče uporabiti katerega od institutov. S tega vidika ni mogoče trditi, da zavezanec lahko izbira, katerega od popravkov bo uporabil, ampak mora izbrati tistega, za katerega izpolnjuje pogoje. Po tej logiki obračuna na podlagi samoprijave ne bi bilo mogoče uporabiti, ko gre za očitne pomote. Tudi ni popolnoma jasno, zakaj bi bilo mogoče očitne pomote uveljavljati le v relativno kratkem roku in se zastavlja vprašanje, ali po njihovem poteku zavezanec sploh lahko sanira take pomote. Velja opozoriti, da se ob sedanji praksi, ko je mogoče izbirati med obračunom po 53. (popravljanje pomanjkljivosti in pomot) in 54. (samoprijava) členu ZDavP-2 zastavlja vprašanje, zakaj bi zavezanci sploh uporabili 53. člen ZDavP-2, saj so pravne posledice zanje bistveno slabše (tj. obveznost plačati obresti po trikrat višji obrestni meri). Logika bi lahko bila zgolj v omejitvi vložitve popravka obračuna na enkratno. Ker pa obračuni vsebujejo zbir cel kup podatkov, se postavlja vprašanje smiselnosti take omejitve. Gre za vprašanja, ki presegajo namen tega prispevka. Vsekakor pa bi bila potrebna tudi analiza ureditve posebnih oblik obračunov in napovedi.
} 
Up-492/11 z dne 9. 5. 2013).

Podobno je nelogična tudi vsebina 62. (davčna napoved po izteku predpisanega roka, kadar razlogi niso opravičljivi) in 63. (davčna napoved na podlagi samoprijave) člena ZDavP-2. Če bi namreč davčni organ davek zaradi napačne napovedi odmeril $\mathrm{v}$ upravnem postopku, ki ni postopek davčnega nadzora, kljub temu da zavezanec napake ne bi odpravil sam z vložitvijo pravilne napovedi, zavezancu ne bi mogel odmeriti obresti. Če pa bi zavezanec sodeloval in bi vložil napoved, bi bil dolžan plačati obresti. Taka ureditev ne spodbuja zavezancev $\mathrm{k}$ naknadnemu vlaganju napovedi, čeprav je bil namen predlagatelja novele ZDavP-2J ravno to.

\subsection{Tek obresti, ko postopek nadzora stoji zaradi davčnega organa}

Zakonodaja predpisuje, koliko najdalj smejo trajati postopki. Praviloma se tudi v davčnih zadevah uporabljajo roki, ki jih določa splošna zakonodaja (222. in 251. člen ZUP), v nekaterih primerih pa jih predpisuje tudi davčna zakonodaja (npr. 84. in 141. člen ZDavP-2). Če stranka postopka, kadar gre za postopke po uradni dolžnosti, kar je vedno pri odmeri davkov, izkaže upravičen interes, sme po preteku predpisanega roka vložiti pritožbo zaradi molka (nedelovanje) organa. Molk organa torej pomeni fikcijo izdane odločbe, ki za stranko ni ugodna (Kerševan \& Androjna, 2017). Roki za končanje postopkov so instrukcijske narave, kar pomeni, da organ po njihovem preteku ne izgubi pravice izdati odločbe. Sama narava rokov ni problematična, sporno pa je, da v praksi davčni organi odmerjajo obresti v postopkih nadzora po 95. členu ZDavP-2 vselej do dejanske izdaje odločbe, čeprav je ta morda izdana po preteku instrukcijskega roka, in čeprav odgovornosti za zamudo pri opravljanju postopka ni mogoče naprtiti stranki, temveč je za to odgovoren organ. Sploh je to problematično v primerih, ko obresti ne pomenijo le nadomestila za uporabo denarja, ampak vsebujejo kazenske pribitke. Tipičen primer takega ravnanja je neizdajanje odločb o odmeri davka od nenapovedanih dohodkov po 68. a členu ZDavP-2, ker je člen $\mathrm{v}$ postopku pred Ustavnim sodiščem (zadeva U-I-133/17). Tam postopek teče že več kot leto dni, v tem času pa večina postopkov davčnega inšpekcijskega postopka stoji, vmes pa zavezancem, ki jim bo morda odmerjen davek, tečejo obresti po 7-odstotni letni obrestni meri. Primerno bi bilo, da bi v primerih, ko je prekoračen rok zaradi neaktivnosti davčnega organa, zakonodajalec določil, da obresti (vsaj tiste s kazenskim pribitkom) prenehajo teči, ko mine instrukcijski 
rok za izdajo odločbe. Trenutno je namreč državi celo v korist (tržne obrestne mere so nizke), da postopki trajajo čim dalj, saj na ta način pridobivajo prihodke iz naslova obresti.

\subsection{Obresti od davka od nenapovedanih dohodkov}

Nekatere nelogičnosti obstajajo tudi glede odmere obresti v zvezi z davkom od nenapovedanih dohodkov po 68.a členu ZDavP-2. V tem članku ni prostora za razpravo, ali po vsebini sploh gre za davek, zato bo uporabljena kar zakonsko izrazoslovje. Nenavadno je, da davčni organi $v$ postopkih davčnega inšpekcijskega nadzora poleg davka odmerjajo obresti po 95. členu ZDavP-2, kajti tega davka ni mogoče obračunati in prostovoljno plačati ali napovedati. Davčni organi v praksi obresti izračunavajo, kot da gre za odmero dohodnine, kar je vprašljivo, če je davek od nenapovedanih dohodkov poseben davek, kjer se (verjetna) vrsta dohodka sploh ne ugotavlja, zato ni nujno, da prirast predstavljajo le dohodki, ki so obdavčeni po ZDoh-2.

\section{$6 \quad$ Obresti pri carinah}

Carine so posebna oblika davka, ki ga je treba plačati od vnosa blaga na carinsko območje, iznos blaga iz carinskega območja ali za tranzit blaga preko carinskega območja (Lovčević, 1979), ki pa ima svoje posebnosti (Doralt, Ruppe, \& EhrkeRabel, 2011). Zaradi načela prostega pretoka blaga znotraj Evropske unije, države članice za prenose blaga med njimi ne smejo uvajati carin in njim podobnih dajatev (Terra \& Wattel, 2012). Temu sledi tudi pravna ureditev, saj je carinsko področje znotraj unificirano urejeno. Pravna podlaga je neposredno uporabna Uredba (EU) št. 952/2013 Evropskega parlamenta in Sveta z dne 9. oktobra 2013 o carinskem zakoniku Unije. ${ }^{30} \mathrm{CZU}$ v 114. členu ureja tudi obresti, ki jih je treba plačati poleg carin (glavnice) v okoliščinah, ki so urejene s predpisom. Člen je poimenovan »zamudne obresti« (angl. Interest on arrears, nem. Verzugszinsen, hrv. zatezne kamate) in določa, da se zamudne obresti na znesek uvozne in izvozne dajatve zaračunavajo od dne izteka predpisanega roka do dne plačila, in sicer $\mathrm{v}$ državah članicah, $\mathrm{v}$ katerih je valuta euro, po obrestni meri, objavljeni v seriji C Uradnega lista Evropske unije, ki jo Evropska centralna banka uporablja za svoje operacije glavnega refinanciranja prvi dan meseca, $\mathrm{v}$ katerem zapade $\mathrm{v}$ plačilo, povečani za dve odstotni točki. Od marca 2016 znaša evropska obrestna mera za

\footnotetext{
${ }^{30}$ Carinski zakonik unije (CZU), Uradni list Evropske unije, št. L 269/1.
} 
operacije glavnega refinanciranja 0 odstotkov, zato znaša obrestna mera zamudnih obresti 2 odstotka letno. To je torej toliko, kot po ZDavP-2 znaša »uporabnina«. Slovenski zakonodajalec je roke za plačilo carinskega dolga predpisal v 23. členu Zakona o izvajanju carinske zakonodaje Evropske unije. ${ }^{31}$ Splošni rok znaša 10 dni od obvestila dolžniku. V določenih primerih (carinski dolg, ki nastane zaradi neizpolnjevanja, in kontrole po prepustitvi blaga), se zamudne obresti zaračunavajo od dne nastanka carinskega dolga. Carinski organi smejo opustiti zaračunavanja zamudnih obresti, če bi njihovo zaračunavanje povzročilo resne ekonomske ali socialne posledice, prav tako se zamudne obresti ne zaračunajo, kadar je znesek posamezne izterjave nižji od 10 EUR.

Za potrebe tega članka lahko ugotovimo, da CZU pozna le eno vrsto obresti, ki jo poimenuje zamudne obresti. Na splošno velja, da obresti tečejo od poteka roka, ko bi moral obveznost izpolniti, torej od zamude, ki nastopi hkrati z zapadlostjo, saj je zavezanec obveščen o višini carinskega dolga in ima postavljen rok za izpolnitev obveznosti. Drugače pa velja za primere nepravilnega ravnanja zavezanca. V tem primeru obresti tečejo od dneva nastanka carinske obveznosti, torej neodvisno od zapadlosti, do obvestila o tem dolgu. Tu pravzaprav po vsebini ne more iti (v celoti) za zamudne obresti, kajti obresti lahko začnejo teči, še preden bi zapadlost in s tem zamuda lahko teoretično nastopila, hkrati pa obresti prenehajo teči, še preden zamuda preneha, saj ta ne more prenehati že z obvestilom, ampak šele z izpolnitvijo (plačilom). Če zavezanec v takem primeru ne bi plačal v roku iz obvestila, bi nastala prava zamuda, zaradi katere bi se mu obračunale »prave« zamudne obresti.

\section{7}

\section{Zaključek}

$\mathrm{Na}$ podlagi predstavite in analize rešitev, ki jih vsebuj ZDavP-2, bi bilo treba ponovno razmisliti o ureditvi sistema obresti od davkov, kajti trenutna ureditev vsebuje nekatere rešitve, ki jih ni mogoče logično zagovarjati. V prvi vrsti bi se pri tem veljalo tudi vprašati, ali trenutno še obstajajo okoliščine, ki jih je imelo $\mathrm{v}$ mislih Ustavno sodišče, ko je izdalo odločbo U-I-356/02 z dne 23. 9. 2004. S skrajšanjem zastaralnih rokov za odmero davka po obračunu (iz 10 na 5 let) in instituti, ki krepijo možnosti zavezancev, da pridobijo podatke o pravilni razlagi davčnih predpisov, bi bilo mogoče zagovarjati, da zamuda lahko nastopi hkrati z

${ }^{31}$ Zakon o izvajanju carinske zakonodaje Evropske unije (ZICZEU), Uradni list RS, št. 32/2016. 
zapadlostjo. Verjetno bi bila država lahko pri tem uspešna, če bi nekoliko zmanjšala dinamiko sprememb davčnih predpisov, okrepila izdajanje pojasnil davčnih predpisov, predvsem pa pojasnilom, ki jih izda davčni organ glede razlage predpisov dala moč za davčni organ zavezujočih aktov, kar pomeni, da se ne bi moglo zgoditi, da bi se zavezanec zanesel na razlago prava s strani davčnega organa, ki bi se kasneje izkazala za napačno, zavezancu pa bi bile odmerjene zamudne obresti. Rešitev bi bilo mogoče iskati tudi v določbi, ki bi omogočala davčnemu organu, da obresti delno odpusti (npr. odmera obresti po obrestni meri brez visokega kaznovalnega pribitka), če bi ugotovil, da je zavezanec imel razloge, da je pravo razlagal na način, kot ga je, čeprav je davčni organ pozneje sprejel drugačno razlago.

V primeru ohranitve pravil, ki bi bile skladne s stališčem Ustavnega sodišča, da zamuda ne nastopi že z zapadlostjo, ampak »šele« z izvršljivostjo, bi bilo nujno, da zakonodajalec ureditev preoblikuje na način, da bi pred zamudo vselej tekle obresti po enaki obrestni meri. Ta bi morala obsegati tržno »uporabnino« za denar, poleg tega pa še določen pribitek, ki ne bi bil previsok, ki bi zagotavljal, da se zavezancem ne izplača »sposojati« denarja od države, ampak na trgu. Različne obrestne mere, kot so uveljavljene danes, katerih višina je odvisna od tega, kako ravna zavezanec kasneje (sam odpravi napako ali pa to prepusti davčnemu organu), bi bilo treba odpraviti. Že določba, ki prenehanje teka obresti veže na naknadno vložitev davčne napovedi ali obračuna davka, spodbuja zavezance, da to storijo čim prej, kajti z vložitvijo ene od teh vlog prekinejo tek obresti, obenem pa se praviloma lahko izognejo globi za storjen prekršek. Nobene potrebe ni, da bi se zavezanca dodatno »spodbujalo«s poviševanjem obrestne mere, ki bolj kot spodbudo, da bi se davčne obveznosti pravilno in pravočasno obračunavale oziroma napovedovale, predstavlja sankcioniranje, ker zavezanec ni izkoristil določene možnosti, ki jo ima (npr. vložitev samoprijave). Trenutno poviševanje obrestnih mer torej ni namenjeno, da bi zavezanci že v osnovi ravnali zakonito, ampak da bi svojo nezakonito ravnanje pozneje sanirali sami, da tega ne bi bilo treba početi davčnim organom.

Zakonodaja bi morala določati, da obresti pred zamudo tečejo šele od trenutka zapadlosti ali vsaj teoretične zapadlosti, ne pa že od trenutka, ko bi zavezanec moral vložiti napoved, kajti popolnoma jasno je, da $\mathrm{v}$ tem trenutku njegova obveznost še ne bo zapadla, saj je z vložitvijo napovedi šele sprožil postopek odmere po uradni dolžnosti. Obresti zaradi ne vložene ali napačne davčne napovedi bi morale teči bodisi vselej, ko zavezanec to stori, bodisi nikoli. 
Ureditev, kot velja danes, ko se obresti odmerijo zgolj v primeru, ko se prenizka odmera davka zaradi ne vložene ali napačne napovedi »sanira« v katerem od postopkov davčnega nadzora, ali z vložitvijo davčne napovedi na podlagi samoprijave, povzroča problematičnost ureditve $z$ vidika načela enakosti pred zakonom. Predvsem pa pred nastankom zamude ne bi smele nikoli teči obresti v višini obrestne mere zamudnih obresti, kot je to v nekaterih primerih predpisano danes.

\section{Literatura}

Accetto, M., Ahtik, M., Dugar, G., Fajfar, T., Ferčič, A., Filipčič, K., . . Žnnidaršič Skubic, V. (2018) Pravni terminološki slovar (Ljubljana: ZRC SAZU).

Antolić, A., Sović Digna, S., Sekulić Grgić, D., Koharić, Z., Petrović, N., Salmić, D., . . Vuraić Kudeljan, M. (2009) Opći porezni zakon i pravilnici s komentarima, sudskom praksom, primjerima i prilozima (Zagreb: Institut za javne financije).

Ax, R., Große, T., Melchior, J., Lotz, A., \& Ziegler, C. (2017) Abgabenordnung und Finanzgerichtsordnung (Stuttgart: Schäffer-Poeschel Verlag).

Birk, D., Desens, M., \& Tappe, H. (2014) Steuerrecht (Heidelberg, München, Landsberg, Frechen, Hamburg: C. F. Müller Verlag).

Brus, M. (2014) Obveznostno pravo (Ljubljana: Uradni list Republike Slovenije).

Cigoj, S. (1998) Teorija obligacij (Ljubljana: Uradni list Republike Slovenije).

Doralt, W., Ruppe, H., \& Ehrke-Rabel, T. (2011) Grundriss des österreichischen Steuerrechts. (Wien: Manzsche Verlags- und Universitätsbuchhandlung).

Gordon, R. K. (1996) Law of Tax Administration and Procedure, V: Thuronyi, V. Tax Law Design and Drafting (Washington: International Monetary Fund), str. 95-134.

Grafenauer, B. \& Breznik, J. (2009) Upravno pravo - procesni del (Ljubljana: GV Založba).

Helmschrott, H., Schaeberle, J., \& Scheel, T. (2016) Abgabenordnung (Stuttgart: SchäfferPoeschel Verlag).

Iglič Stroligo, K. (2011) Zapadlost terjatve in zamuda, Pravosodni bilten, 32(2), str. 47-65.

Jerovšek, T., Simič, I., Škof, B., Wakounig, M., Jeman, S., Krisper Mendušič, M., . . . Hadjar, R. (2008) Zakon o davčnem postopku s komentarjem (Ljubljana in Maribor: Davčno izobraževalni inštitut in Davčno finančni raziskovalni inštitut).

Kerševan, E. (2008) Uporaba materialnega prava pri odločanju v rednem upravnem postopku z vidika temeljnih načel pravne države, V: Zbornik znanstvenih rasprav, str. 129-150.

Kerševan, E. \& Androjna, V. (2017) Upravno procesno pravo (Ljubljana: IUS Software (GV Založba)).

Kruse, H. W. (1991) Lebrbuch des Stenerrechts (München: C. H. Beck).

Lammerding, J., Scheel, T. \& Brehm, B. (2012) Abgabenordnung unf Finanzgerichtsordnung (Achim: Erich Fleischer Verlag).

Lovčević, J. (1979) Institucije javnih finansija (Beograd: Službeni list SFRJ).

Maier, W. \& Grimm, S. (2014) Bürgerliches Recht und Stenerrecht (Stuttgart: Schäffer-Poeschel Verlag).

Muha, M. (2017) Zastaranje v davčnem pravu, Podjetje in delo, 43(1), str. 48-56. 
Plavšak, N., Juhart, M., \& Vrenčur, R. (2009) Obligacijsko pravo - splošni del (Ljubljana: GV založba).

Plavšak, N., Juhart, M., Kranjc, V., Polajnar Pavčnik, A. \& Grilc, P. (2003) Obligacijski zakonik s komentarjem (2. knjiga) (Ljubljana: GV založba).

Podlipnik, J. (2011) Samoprijava po Zakonu o davčnem postopku, Podjetje in delo, 37(8), str. 1668-1690.

Podlipnik, J. (2015) Materialna zakonitost pri določanju davčnih obveznosti z vidika časovne veljavnosti, Zbornik znanstvenih råprav, 75, str. 103-122.

Podlipnik, J. (2018) Ustavna ustreznost tretjega odstavka 71. člena novele ZDavP-2J. Davǒno-finančna praksa, 19(2), str. 7-9.

Popović, D. (2003) Komentar Zakona o poreskom postupku i poreskoj administraciji (Beograd: Cekos in).

Strohsack, B. (1996) Obligacijska razmerja III (Ljubljana: Uradni list Republike Slovenije).

Šinkovec, J. \& Tratar, B. (2002) Zakon o davčnem postopku s komentarjem (Lesce: Oziris).

Škof, B. (2004) O nekaterih dilemah novega Zakona o davčnem postopku, Davčno-finančna praksa, 5(11), str. 5-8.

Špilar, M. (2018) Samoprijava davka - institut za prekrškovno oprostitev zavezanca ali povečanje davčnih prihodkov, Gradivo seminarja Gospodarski subjekti na trgu in evropske dimenzije (Maribor: Pravna fakulteta).

Terra, B. \& Wattel, P. (2012) European Tax Law (Alphen aan den Rijn: Kluwer Law International).

Tratar, B. \& Kruhar Puc, R. (2005) Novi davǒni postopek - Zakon o davǐnem postopku s pojasnili in primeri izprakse (Lesce: Legat). 


\title{
Prepletanje prostorske in gradbene zakonodaje s stvarnim pravom
}

\author{
RENATO VRENČUR
}

Povzetek Zakon o urejanju prostora (ZUreP-2) in Gradbeni zakon (GZ) sta posegla $\mathrm{v}$ določene splošne institute civilnega prava. $\mathrm{V}$ prispevku poskušamo analizirati predvsem položaje, ko prihaja do stika javnega prava s stvarnim pravom, in sicer na področju graditve objektov in urejanja gospodarske javne infrastrukture. V Sloveniji še ni oblikovana ustaljena sodna praksa glede skrajne meje dopustnosti posegov $\mathrm{v}$ zasebno lastnino zaradi zagotavljanja javne koristi. Predstavljeni interesni konflikti med javnim in zasebnim so najbrž posledica tranzicije $\mathrm{v}$ nek drug pravni sistem, $\mathrm{s}$ (pregovorno) posebej naglašenimi ustavnopravnimi garancijami do zasebne lastnine. Sodna praksa Vrhovnega sodišča RS po oceni Ustavnega sodišča RS s svojimi nosilnimi stališči (na primeru služnosti v javno korist) povsem spregleda pomen obrambne funkcije pravice do zasebne lastnine. Zato ne daje nobene ustavnopravne teže jamstvom iz 69. člena Ustave. Prav zaradi tega stališče o dopustnosti (brezplačnega) priposestvovanja služnosti $v$ javno korist ni sprejemljivo z vidika pravice do zasebne lastnine iz 33 . člena v zvezi z 69. členom Ustave RS.

Ključne besede: $\bullet$ stvarno pravo $\bullet$ javno pravo $\bullet$ nepremičnine $\bullet$ javno dobro $\bullet$ graditev objektov $\bullet$ služnosti $\bullet$ razlastitev $\bullet$

NASLOV AVTORJA: Renato Vrenčur, Univerza v Maribor, Pravna fakulteta, Maribor, Slovenija, epošta: renato.vrencur@um.si. 


\title{
Influence of Spatial Planning Legislation and Construction Legislation on Property Law
}

\author{
RENATO VRENČUR
}

\begin{abstract}
Spatial Planning Act (ZUreP-2) and Building Act (GZ) effect on certain general institutes of civil law. In this article we try to analyze the situation, when it comes to contact between the public and property law, namely in the field of building construction and regulation of public infrastructure. In Slovenia it has not yet developed settled case-law regarding the admissibility of the extreme limits of intervention into private property to ensure the public interest. Featured conflicts of interest between public and private are probably a result of the transition to a different legal system, whit the (proverbial) specially accented constitutional guarantees of private property. The case law of the Supreme Court of the Republic of Slovenia (in the case of an easement in the public interest) completely overlook the importance of the defense function of the right to private property. So it does not give any weight to the constitutional guarantee under Article 69 of the Constitution of the Repulic of Slovenia. Consequently, the position on the admissibility of the free acquisition of easements in the public interest is not acceptable from the perspective of the right to private property under Article 33 in connection with Article 69 of the Constitution of the Republic of Slovenia.
\end{abstract}

Keywords: $\bullet$ property law $\bullet$ public law $\bullet$ real estate $\bullet$ public good $\bullet$ construction of building $\bullet$ easement $\bullet$ expropriation $\bullet$

CORRESPONDENCE ADDRESS: Renato Vrenčur, University of Maribor, Faculty of Law, Maribor, Slovenia, e-mail: renato.vrencur@um.si. 


\section{$1 \quad$ Uvod}

1. junija 2018 sta pričela veljati pomembna predpisa, ki celovito urejata področje urejanja prostora in prostorske ukrepe ter graditev objektov. To sta ZUreP-2 ${ }^{1}$ in $\mathrm{GZ}^{2}$. S tem se derogirajo zlasti ZUreP-1 ${ }^{3}, \mathrm{ZPNačrt}^{4}$, ZUPUDPP5 in ZGO-16. Pri tem je treba opozoriti na nomotehnični pristop urejanja materije $\mathrm{v}$ posameznih predpisih. Tako se npr. pravni režim grajenega javnega dobra seli v ZUreP-2 (prej je bil urejen v ZGO-1), v ZUreP-2 se seli tudi potrdilo o namenski rabi zemljišča (prej je bilo urejeno v ZPNačrt), dograjuje se pravni režim zakonite predkupne pravice občine na poselitvenih območjih, ki se širi tudi na državo kot predkupno upravičenko ter na območja drugih vrst nepremičnin (materija ima mesto v ZUreP-2) ipd.

$S$ področjem nepremičninskega stvarnega prava se prepletajo zlasti naslednji instituti, ki bodo predmet obravnave tega prispevka:

- dokazilo o pravici graditi ter prepovedi zaradi nedovoljene gradnje;

- potrdilo o namenski rabi zemljišča;

- zakonita predkupna pravica občine in države;

- grajeno javno dobro;

- problematika javnih cest in

- služnosti v javno korist.

\footnotetext{
${ }^{1}$ Zakon o urejanju prostora - ZUreP-2 (Uradni list RS, št. 61/2017).

${ }^{2}$ Gradbeni zakon - GZ (Uradni lisr RS, št. 61/17 in 72/17 - popr.).

3 Zakon o urejanju prostora - ZUreP-1 (Uradni list RS, št. 110/02, 8/03 - popr., 58/03 - ZZK-1, 33/07 ZPNačrt, 108/09 - ZGO-1C, 80/10 - ZUPUDPP in 61/17 - ZUreP-2).

${ }^{4}$ Zakon o prostorskem načrtovanju - ZPNačrt (Uradni list RS, št. 33/07, 70/08 - ZVO-1B, 108/09, 80/10 ZUPUDPP, 43/11 - ZKZ-C, 57/12, 57/12 - ZUPUDPP-A, 109/12, 76/14 - odl. US, 14/15 - ZUUJFO in 61/17 - ZUreP-2).

${ }^{5}$ Zakon o umeščanju prostorskih ureditev državnega pomena v prostor (Uradni list RS, št. 80/10, 106/10 popr., 57/12 in 61/17 - ZUreP-2).

${ }^{6}$ Zakon o graditvi objektov - ZGO-1 (Uradni list RS, št. 102/04 - uradno prečiščeno besedilo, 14/05 - popr., 92/05 - ZJC-B, 93/05 - ZVMS, 111/05 - odl. US, 126/07, 108/09, 61/10 - ZRud-1, 20/11 - odl. US, 57/12, $101 / 13$ - ZDavNepr, 110/13, 19/15, 61/17 - GZ in 66/17 - odl. US).
} 


\section{Dokazilo o pravici graditi in prepovedi zaradi nedovoljene gradnje}

\subsection{Dokazilo o pravici graditi}

Kot dokazilo o pravici graditi se navajata zlasti vknjižena lastninska pravica in stavbna pravica. Obe stvarni pravici vključujeta takšna materialnopravna upravičenja, ki zagotavljajo gradnjo objektov. Obe pravici vključujeta upravičenje uporabe (pravico imeti stvar $\mathrm{v}$ posesti, jo rabiti in uživati), razpolagalno upravičenje (ki zagotavlja pravno možnost odtujiti oz. obremeniti pravico) ter pravovarstveni zahtevek. Razlika med obema navedenima stvarnima pravica je predvsem ta, da je stavbna pravica časovno omejena izvedena stvarna pravica, medtem ko predstavlja lastninska pravica časovno neomejeno stvarnopravno pozicijo.

Lastninska pravica je pravica imeti stvar $\mathrm{v}$ posesti, jo uporabljati in uživati na najobsežnejši način ter $z$ njo razpolagati. Omejitve uporabe, uživanja in razpolaganja lahko določi samo zakon. Lastninska pravica ne more biti vezana na rok ali pogoj, razen če zakon določa drugače (glej 37. člen SPZ).

Stavbna pravica je pravica imeti v lasti zgrajeno zgradbo nad ali pod tujo nepremičnino. Stavbna pravica ne sme trajati več kot devetindevetdeset let. Stavbna pravica je prenosljiva. Za prenos stavbne pravice se smiselno uporabljajo določila, ki veljajo za prenos lastninske pravice na nepremičninah (256. člen SPZ).

Če investitor gradnje $\mathrm{v}$ zemljiški knjigi nima vpisane lastninske ali druge stvarne pravice na nepremičninah, na katerih se bo izvajala gradnja, zadošča za izkazovaje pravice graditi:

- notarsko overjena pogodba o pridobitvi te pravice, ki je predlagana za vpis v zemljiško knjigo,

- $\quad$ sodna ali upravna odločba, ki mu omogoča gradnjo oziroma izvajanje del,

- $\quad$ sklep o določitvi investitorja kot upravljavca nepremičnine, če gre za nepremičnino $\mathrm{v}$ lasti njegovega ustanovitelja, razen če je iz uradnih evidenc razvidno, da je investitor zakoniti upravljavec, ali 
- drugo listino, ki v skladu z zakonom omogoča gradnjo oziroma izvajanje del.

V praksi se je ne redko postavilo vprašanje: »ali predstavlja status dokončnega upravljavca nepremičnin, ki so last Republike Slovenije, pravico graditi v smislu 56. člena ZGO-1?«

$\mathrm{Na}$ podlagi novega 58. člena ZSPDSLS-1 obsega upravljanje nepremičnega ${ }^{7}$ premoženja zlasti: skrb za pravno in funkcionalno urejenost; investicijska vzdrževalna dela; nastopanje $\mathbf{v}$ vlogi investitorja $\mathbf{v}$ imenu in za račun zemljiškoknjižnega lastnika pri pridobivanju dovoljenj po predpisih, ki urejajo graditev objektov, in pri pripravi, organiziranju in vodenju investicij $v$ vseh fazah investicijskega procesa in podobno, oblikovanje predlogov novih prostorskih rešitev za nepremičnine $\mathrm{v}$ upravljanju in sodelovanje pri pripravi prostorskih aktov, oddajo v najem; oddajo v občasno uporabo, oddajo v brezplačno uporabo; obremenjevanje s stvarnimi pravicami.

Novi GZ je v tej zvezi določil sprejemljivejše pogoje za izkazovanje (in dokazovanje) pravice graditi, ki ustrezajo gornjim pomislekom. V 3. tč. drugega odstavka 35. člena GZ je določeno sledeče:

»3. če investitor $\mathrm{v}$ zemljiški knjigi nima vpisane lastninske ali druge stvarne pravice $^{8}$ na nepremičninah, na katerih se bo izvajala gradnja:

- notarsko overjeno pogodbo o pridobitvi te pravice, ki je predlagana za vpis v zemljiško knjigo,

- sodno ali upravno odločbo, ki mu omogoča gradnjo oziroma izvajanje del,

- sklep o določitvi investitorja kot upravljavca nepremičnine, če gre za nepremičnino $\mathrm{v}$ lasti njegovega ustanovitelja, razen če

\footnotetext{
${ }^{7}$ Postopke upravljanja nepremičnega premoženja države in samoupravnih lokalnih skupnosti izvaja upravljavec (drugi odstavek 58. člena Zakona o stvarnem premoženju države in samoupravnih lokalnih skupnosti ZSPDSLS-1; Uradni list RS, št. 11/2018).

8 Zakon nekoliko moteče zapiše »ali druga stvarna pravicau. Glede na to, da stvarno breme in hipoteka že pojmovno ne moreta priti v poštev kot dokazilo o pravici graditi (ker ne vključujeta upravičenja uporabe tuje nepremičnine), nam ostaneta še samo stavbna pravica in služnostna pravica. Glede na dejstvo, da velja v stvarnem pravu numerus clausus stvarnih pravic, jih najverjetneje zakonodajalcu ne bi smelo biti težko prešteti in namesto »ali druge stvarne pravice« jasno zapisati »ali stavbne oz. služnostne pravice«.
} 


\section{je iz uradnih evidenc razvidno, da je investitor zakoniti upravljavec, ali \\ - drugo listino, ki v skladu z zakonom omogoča gradnjo oziroma izvajanje del.«}

Pri nameravani gradnji objektov gospodarske javne infrastrukture, ki se izvaja v cestnem telesu javne ceste, skupaj s priključki, se za dokazilo o pravici graditi šteje soglasje upravljavca javne ceste za izvedbo gradnje $\mathbf{v}$ cestnem telesu (tretji odstavek 35. člena GZ). Problem, ki se pojavlja zelo pogosto, je ostal pomanjkljivo rešen. Pogosto se zaradi gradnje posega v nepremičnine s statusom cestnega javnega dobra pri izvajanju zasebnih projektov (npr. nameščanje sider za zaščito gradbenih jam oz. gradnja pilotov za zaščito gradbenih jam pri gradnji raznih poslovno stanovanjskih objektov), pri čemer ne gre za gradnjo objektov gospodarske javne infrastrukture, kjer zadošča za pridobitev gradbenega dovoljenja zgolj soglasje upravljavca javne ceste. Zamislimo si lahko izgradnjo betonskih pilotov (oziroma pilotne stene $\mathrm{v}$ dolžini 20,00 m) za zavarovanje gradbene jame (piloti imajo npr. premer $50 \mathrm{~cm}$, namestijo se $0,40 \mathrm{~m}$ pod finalno koto pločnika za pešce v globino do $10,00 \mathrm{~m}$. Namestijo se na nepremičnini (javni cesti, ki ima status javnega dobra), ki je last občine. Navpična postavitev pilotov se torej izvede pod koto 0. Ta okoliščina je pomembna zaradi tega, ker SPZ izrecno dovoljuje ustanovitev stavbne pravice na javnem dobru (kot posebne pravice uporabe javnega dobra) le $\mathrm{v}$ primeru, če se s tem ne posega $\mathrm{v}$ splošno rabo javnega dobra (265. člen SPZ). Takšno stavbno pravico je po naši oceni dopustno ustanoviti tudi na javni cesti. $\mathrm{V}$ poštev pride predvsem ustanovitev stavbne pravice pod koto 0 , kar zagotavlja neovirano splošno rabo ceste, kot javnega dobra. Javne ceste so glede na 3. člen ZCes- $1{ }^{9}$ prometne površine, ki so splošnega pomena za promet in jih lahko vsak prosto uporablja na način in pod pogoji, določenimi s predpisi, ki urejajo ceste, in pravili cestnega prometa. Javne ceste so praviloma izven pravnega prometa. Pravilo ne velja absolutno, saj je na zemljiščih t.i. cestnega sveta mogoče pridobiti služnost za gradnjo objektov gospodarske javne infrastrukture in priključkov nanjo ter vodov, za gradnjo cestnega priključka na javno cesto, kakor tudi stavbno pravico, če se s tem ne posega v splošno rabo cestnega javnega dobra (glej deseti odstavek 3. člena ZCes-1 v zvezi s 265. členom SPZ).

${ }^{9}$ Zakon o cestah - ZCes-1 (Uradni list RS, št. 109/2010, 48/2012, 36/2014-odl. US, 46/2015 in 10/2018). 
Dejstvo je, da pozitivna zakonodaja, zlasti ZCes-1, ne omogoča ustanovitve služnostne pravice zunaj primerov, ki jih določa 3. člen ZCes-1 (po tej določbi se izkazuje pravica graditi na podlagi pridobljene služnostne pravice samo $\mathrm{v}$ primerih gradnje gospodarske javne infrastrukture). Ne glede na dejstvo, da bi v mnogih primerih po namenu bolj ustrezala služnostna pravica, kot stavbna pravica, morajo zasebni investitorji (v okviru dopustnih pravnih možnosti) pravno razmerje $z$ občinami ali državo, ki sta lastnici javnih cest, urediti z ustanovitvijo odplačne stavbne pravice, v skladu s predpisi, ki urejajo ravnanje s stvarnim premoženjem države in samoupravnih lokalnih skupnosti (Zakon o stvarnem premoženju države in samoupravnih lokalnih skupnosti - ZSPDSLS$1^{10}$ in Uredba o stvarnem premoženju države in samoupravnih lokalnih skupnosti $\left.{ }^{11}\right)$.

Na nepremičninah, na katerih so predvidene začasne ureditve za potrebe gradnje, se za dokazilo o pravici graditi šteje tudi notarsko overjena pogodba o pridobitvi obligacijske pravice, ki omogoča takšno ureditev na tuji nepremičnini (četrti odstavek 35. člena GZ). Gre npr. za začasne deponije zemljin, začasne postavitve naprav ipd.

\begin{tabular}{|c|c|}
\hline 56. člen ZGO-1 & 35. člen GZ \\
\hline $\begin{array}{l}\text { 56. člen } \\
\text { (dokazilo o pravici graditi) } \\
\text { (1) Za dokazilo o pravici graditi po } \\
\text { tem zakonu velja: } \\
\text { - izpisek iz zemljiške knjige, iz } \\
\text { katerega izhaja, da ima investitor na } \\
\text { določeni nepremičnini lastninsko ali } \\
\text { kakšno drugo stvarno oziroma } \\
\text { obligacijsko pravico, ki mu } \\
\text { omogoča gradnjo oziroma izvajanje } \\
\text { del na takšni nepremičnini, } \\
\text { - notarsko overjena pogodba z } \\
\text { dokazilom o vložitvi predloga za } \\
\text { vpis pogodbe o pridobitvi lastninske } \\
\text { ali kakšne druge stvarne oziroma }\end{array}$ & $\begin{array}{l}\text { 35. člen } \\
\text { (zahteva za izdajo gradbenega } \\
\text { dovoljenja) } \\
\text { (1) Zahtevo za izdajo gradbenega } \\
\text { dovoljenja vloži investitor na obrazcu. } \\
\text { (2) Zahtevi za izdajo gradbenega } \\
\text { dovoljenja se priložijo: } \\
\text { 1. dokumentacija za pridobitev } \\
\text { gradbenega dovoljenja s podatki, } \\
\text { določenimi v predpisu iz osmega } \\
\text { odstavka 29. člena tega zakona, } \\
\text { mnenja pristojnih mnenjedajalcev, } \\
\text { razen če se nameravana gradnja } \\
\text { nahaja na območju prostorskega } \\
\text { izvedbenega akta, h kateremu so }\end{array}$ \\
\hline
\end{tabular}

${ }^{10}$ Uradni list RS, št. 11/2018.

11 Uradni list RS, št. 31/2918. 
obligacijske pravice na določeni nepremičnini v zemljiško knjigo, ki investitorju dovoljuje gradnjo oziroma izvajanje del na takšni nepremičnini,

- pravnomočna sodna ali upravna odločba, ki izkazuje pravico graditi oziroma izvajati dela na nepremičnini, ali

- druga listina, ki v skladu z zakonom izkazuje pravico graditi oziroma izvajati dela na določeni nepremičnini. mnenjedajalci kot nosilci urejanja prostora dali pozitivno mnenje in se v njem izrekli, da pridobivanje mnenj $\mathrm{v}$ postopku izdaje gradbenega dovoljenja ni potrebno,

3. če investitor $\mathrm{v}$ zemljiški knjigi nima vpisane lastninske ali druge stvarne pravice na nepremičninah, na katerih se bo izvajala gradnja:

- notarsko overjeno pogodbo o pridobitvi te pravice, ki je predlagana za vpis $\mathrm{v}$ zemljiško knjigo,

- sodno ali upravno odločbo, ki mu omogoča gradnjo oziroma izvajanje del,

- sklep o določitvi investitorja kot upravljavca nepremičnine, če gre za nepremičnino $\mathrm{v}$ lasti njegovega ustanovitelja, razen če je iz uradnih evidenc razvidno, da je investitor zakoniti upravljavec, ali

- drugo listino, ki $\mathrm{V}$ skladu $\mathrm{z}$ zakonom omogoča gradnjo oziroma izvajanje del.

(3) Pri nameravani gradnji objektov gospodarske javne infrastrukture, ki se izvaja $\mathrm{v}$ cestnem telesu javne ceste, skupaj s priključki, se ne glede na določbe tega člena za dokazilo iz 3 . točke prejšnjega odstavka šteje soglasje upravljavca javne ceste za izvedbo gradnje v cestnem telesu.

(4) $\mathrm{Na}$ nepremičninah, na katerih so predvidene začasne ureditve za potrebe 
gradnje, se za dokazilo iz 3. točke drugega odstavka tega člena šteje tudi notarsko overjena pogodba o pridobitvi obligacijske pravice, ki omogoča takšno ureditev na tuji nepremičnini.

(5) Šteje se, da je zahteva za izdajo gradbenega dovoljenja popolna, če so priloženi dokumenti iz 1 . in 3. točke drugega odstavka tega člena.

(6) Pristojni upravni organ za gradbene zadeve mora ob nepopolni zahtevi za izdajo gradbenega dovoljenja najpozneje v 15 dneh od njenega prejema zahtevati dopolnitev.

(7) $\mathrm{Na}$ zahtevo vlagatelja pristojni upravni organ za gradbene zadeve izda sklep o popolnosti vloge $\mathrm{v}$ skladu $\mathrm{s}$ petim odstavkom tega člena.

(8) Obrazec iz prvega odstavka tega člena predpiše minister.

\subsection{Prepovedi zaradi nedovoljene gradnje}

Veliko polemik se je razvnelo okoli določbe 93. člena GZ, s katero je želel zakonodajalec urediti pravni režim posebnih prepovedi za nedovoljene objekte in neskladno uporabo objekta (beri tudi: prepovedi zaradi nedovoljene gradnje).

Za nedovoljen objekt in neskladno uporabo objekta so glede na vrsto gradnje prepovedana naslednja dejanja: (1) izvedba komunalnih priključkov na gospodarsko javno infrastrukturo, (2) vpisi in spremembe vpisov v zemljiški knjigi, (3) uporaba ali opravljanje gospodarskih ali drugih dejavnosti, (4) promet z njimi ali zemljišči, na katerih so, (5) overitve pogodb, sklepanje pravnih poslov, sklenitev kreditnih, zavarovalnih, najemnih, zakupnih, delovršnih in drugih pravnih poslov ter (6) določitev hišne številke (prvo odstavek 93. člena GZ). Navedene prepovedi se odredijo z odločbo, s katero se izreče inšpekcijski ukrep (drugi odstavek 93. člena GZ). Zakon nadalje določa, da so dovoljenja, soglasja, vpisi, pravni posli in drugi pravni akti, ki so v nasprotju z izrečenimi prepovedmi 
nični, razen če so predpisani ali odrejeni na podlagi GZ (glej tretji odstavek 93. člena GZ). Če je bila priključitev objekta na gospodarsko javno infrastrukturo izvedena, pristojni gradbeni inšpektor naloži upravljavcu, da ga odklopi. Če je nedovoljen objekt priključen na legalni objekt, se odklopi tudi ta objekt (četrti odstavek 93. člena GZ). Nekoliko nerodno pa je zapisana določba petega odstavka 93. člena GZ, ki pravi, da morajo upravljavci, notarji, pooblaščeni inženirji s področja geodezije in druge osebe javnega ali zasebnega prava in drugi organi, pristojni za izvedbo dejanj iz prvega odstavka 93. člena GZ pred njihovo izvedbo preveriti, ali je za objekt izdano gradbeno dovoljenje, kadar je predpisano, in ali je $\mathrm{v}$ zemljiški knjigi vpisana zaznamba o prepovedi $\mathrm{v}$ skladu $\mathrm{s}$ 94. členom tega zakona.

Gradbeni inšpektor, občinski inšpektor ali drug inšpektor, ki je izdal odločbo, s katero se izreče inšpekcijski ukrep v zvezi z nedovoljenim objektom ali neskladno uporabo objekta, nemudoma obvesti zemljiškoknjižno sodišče in priloži izvršljivo odločbo. Zemljiškoknjižno sodišče po uradni dolžnosti vpiše v zemljiško knjigo zaznambo izrečenega inšpekcijskega ukrepa in posebnih prepovedi. Inšpektor o izdaji odločbe obvesti tudi organ, ki vodi zemljiški kataster (prvi odstavek 94. člena GZ). Zemljiškoknjižno sodišče vpiše zaznambo $\mathrm{v}$ zemljiško knjigo tudi, če lastnik zemljišča ali objekta ni ista oseba kot inšpekcijski zavezanec. Zaznamba se vpiše pri vseh imetnikih lastninske ali stavbne pravice na nepremičnini (drugi odstavek 94. člena GZ). ${ }^{12}$

Prepovedi zaradi nedovoljene gradnje (iz prvega odstavka 93. člena GZ) zajemajo (poleg ostalih prepovedi) praktično vse načine (pravnoposlovnega) razpolaganja $z$ lastninsko pravico na nepremičnini (ter sklepanje vseh drugih pravnih poslov). Ker se to pravno dejstvo vpisuje v zemljiško knjigo (glej 159. člen ZGO-1 ter 94. člen GZ v zvezi s 100.a členom ZZK-1), se ta preveritev omeji na preveritev, ali je $\mathrm{v}$ zemljiški knjigi vpisana zaznamba prepovedi zaradi nedovoljene gradnje $\mathrm{v}$ skladu s 100.a člena ZZK-1. Če pravica ali pravno dejstvo, za katerega zakon določa, da se vpisuje $\mathrm{v}$ zemljiško knjigo, $\mathrm{v}$ zemljiški knjigi ni vpisana, se šteje, da

\footnotetext{
12 V tej zvezi je že pred uveljavitvijo GZ takšno stališče zavzela sodna praksa v zadevi VS, Sklep II Ips 245/2013, 23.6.2014: Pri zaznambi mora listina dokazovati nastop pravnega dejstva, ki je predmet vpisa, in ustrezati drugim pogojem, določenim z zakonom (glej drugi odstavek 29. člena ZZK-1). ZGO-1 pa za zaznambo v zemljiški knjigi ne določa pogoja, da se mora odločba upravnega organa nanašati tudi na zemljiškoknjižnega lastnika, oziroma da mora biti investitor nedovoljeno zgrajenega objekta hkrati tudi lastnik zemljišča, na katerem je zgrajen tak objekt. Zato je pritrditi tezi tožilstva, da je v obravnavani zadevi listina, ki je podlaga za vpis, izvršljiva upravna odločba Inšpektorata RS za okolje in prostor, na podlagi katere se določene prepovedi, vsebovane v tej odločbi, zaznamujejo v zemljiško knjigo.
} 
tretji za to pravico oziroma pravno dejstvo ni vedel, če se ne dokaže drugače (drugi odstavek 6. člena ZZK-1).

GZ uporablja izraz nedovoljen objekt, kar vključuje nelegalen objekt, neskladen objekt in nevaren objekt.

Nelegalen objekt je objekt, ki se gradi ali ki je zgrajen brez pravnomočnega gradbenega dovoljenja ali $\mathrm{v}$ nasprotju s pogoji, določenimi z gradbenim dovoljenjem, če ga gradbeno-tehnično ni mogoče uskladiti z gradbenim dovoljenjem. Nelegalen objekt sta tudi objekt, za katerega je bilo gradbeno dovoljenje ali dovoljenje za objekt daljšega obstoja odpravljeno ali razveljavljeno in objekt, za katerega ni predpisano gradbeno dovoljenje, če je zgrajen v nasprotju s prostorskim izvedbenim aktom ali drugim predpisom občine.

Neskladen objekt je objekt, ki ima pravnomočno gradbeno dovoljenje, vendar se gradi ali je zgrajen $v$ nasprotju s pogoji, določenimi z gradbenim dovoljenjem, tako, da ga je gradbeno-tehnično mogoče uskladiti z gradbenim dovoljenjem in pri tem ne gre za dopustna odstopanja v skladu s 66. členom GZ.

Neskladna uporaba objekta je uporaba objekta ali dela objekta brez uporabnega dovoljenja, $\mathrm{v}$ nasprotju $\mathrm{z}$ izdanim gradbenim dovoljenjem ali nasprotju $\mathrm{z}$ uporabnim dovoljenjem.

Nevaren objekt je objekt, ki ne izpolnjuje bistvenih zahtev, tako da neposredno ogroža zdravje in življenje ljudi, premoženje večje vrednosti, promet ali sosednje objekte (3. člen GZ).

V 94. členu GZ, ki določa vpis zaznambe prepovedi zaradi nedovoljene gradnje $\mathrm{v}$ zemljiško knjigo, niso podrobneje urejeni učinki te zaznambe. Zato se zanje po 100.a členu ZZK-1 smiselno uporabljajo pravila o zaznambi prepovedi odtujitve in obremenitve na podlagi sodne odločbe (začasne odredbe), ki so urejena $\mathrm{v}$ določbah 98., 99. in 100. člena ZZK-1. Pri oblikovanju 100.a člena ZZK-1 je prišlo do redakcijske napake, saj citirani člen napačno napotuje na smiselno uporabo prvega odstavka 100. člena ZZK-1, ki določa, da se zaradi kasnejšega vpisa, za katerega zaznamba (prepovedi odtujitve in obremenitve) ni ovira, hkrati z dovolitvijo vknjižbe lastninske pravice, po uradni dolžnosti dovoli tudi izbris zaznambe. To pravilo velja le za zaznambo prepovedi odtujitve in obremenitve, ne pa za zaznambo prepovedi zaradi nedovoljene gradnje. To pomeni, da se pri 
prisilni prodaji nepremičnine $\mathrm{v}$ izvršilnem ali stečajnem postopku ta zaznamba (prepovedi zaradi nedovoljene gradnje) ne izbriše, temveč učinkuje tudi proti novemu pridobitelju. ${ }^{13}$ Pri prisilni prodaji nepremičnine zaznamba prepovedi odtujitve in obremenitve ni ovira za vknjižbo lastninske pravice $\mathrm{v}$ korist novega lastnika. Tudi zaznamba prepovedi zaradi nedovoljene gradnje $\mathrm{v}$ primeru prisilne prodaje ni ovira za vknjižbo lastninske pravice v korist novega lastnika, vendar pa se zaznamba prepovedi zaradi nedovoljene gradnje ne izbriše, kot to velja za zaznambo prepovedi odtujitve in obremenitve. Kljub prisilni prodaji nepremičnine v izvršilnem ali stečajnem postopku, gradnja ne izgubi lastnosti nedovoljene gradnje, zato je razumljivo, da ostane to pravno dejstvo vpisano ter učinkuje tudi proti novemu pridobitelju. Določba 100.a člena ZZK-1 se zato pravilno glasi tako: "Za zaznambo prepovedi zaradi nedovoljene gradnje, izrečene kot inšpekcijski ukrep po zakonu, ki ureja graditev objektov, se smiselno uporabljajo 98. člen, 99. člen ter tretji in četrti odstavek 100. člena ZZK-1.«

Zaradi pravilnega razumevanja pravnih učinkov vpisa zaznambe prepovedi zaradi nedovoljene gradnje, je treba pogledati osnovno razvrstitev javnopravnih omejitev. Javnopravne omejitve razvrščamo glede na:

1. začetek učinkovanja javnopravne omejitve (trenutek nastopa oblikovalnih učinkov);

2. način javne objave javnopravne omejitve.

Po začetku učinkovanja (po trenutku nastopa oblikovalnih učinkov javnopravne omejitve) razvrščamo javnopravne omejitve na dve podvrsti:

1. javnopravne omejitve, pri katerih nastopijo oblikovalni učinki z odločbo (s pravnomočnostjo upravne odločbe) (na primer odločba o razlastitvi, odločba o podelitvi statusa javnega dobra, odločba o nedovoljeni gradnji, odločba o določitvi statusa zaščitene kmetije);

\footnotetext{
13 Predlog Zakona o spremembah in dopolnitvah Zakona o zemljiški knjigi (ZZK-1C); EPA 1152-V - prva obravnava, stran 43. Obrazložitev v predlogu zakona je bila pravilna, le pri določbi 100.a člena ZZK-1 je napačno navedena smiselna uporaba prvega odstavka 100. člena ZZK-1. Poleg tega je treba upoštevati tudi tretjo točko drugega odstavka 89. člena ZZK-1, ki določa, da zemljiškoknjižno sodišče, ki dovoli vknjižbo lastninske pravice $\mathrm{v}$ korist kupca na podlagi pravnomočnega sklepa o izročitvi nepremičnine, hkrati po uradni dolžnosti dovoli tudi izbris zaznambe prepovedi odtujitve in obremenitve, ne glede na to, od katerega trenutka učinkuje. Pravkar citirana določba pa tega ne določa za zaznambo prepovedi zaradi nedovoljene gradnje, kar je dodatni argument, da se zaznamba prepovedi zaradi nedovoljene gradnje, kljub prisilni prodaji nepremičnine $\mathrm{v}$ izvršilnem ali stečajnem postopku, ne izbriše in učinkuje tudi proti novemu lastniku nepremičnine.
} 
2. javnopravne omejitve, pri katerih nastopijo oblikovalni učinki $\mathrm{z}$ uveljavitvijo splošnega akta (uredba ali odlok vlade, odlok samoupravne lokalne skupnosti; zlasti pri nepremičnih spomenikih).

Po načinu javne objave, razvrščamo javnopravne omejitve na tiste, ki se objavijo:

1. samo $v$ javni evidenci upravnih organov (na primer zakonita predkupna pravica po ZUreP-2 v potrdilu o namenski rabi zemljišča);

2. $\mathrm{v}$ zemljiški knjigi kot zaznambe pravnega dejstva o javnopravnih omejitvah (zaznamba javnega dobra, zaznamba nepremičnega spomenika, zaznamba zavarovanega območja, zaznamba zašcitene kmetije, zaznamba nedovoljene gradnje in zaznamba razlastitvenega postopka). Glavnina zaznamb pravnega dejstva o javnopravnih omejitvah je enotno urejena $v$ 111. členu ZZK-1 (zaznamba javnega dobra, zaznamba nepremičnega spomenika, zaznamba zavarovanega območja, zaznamba zaščitene kmetije). Posebej sta urejeni zaznamba nedovoljene gradnje (100.a člen ZZK-1) in zaznamba razlastitvenega postopka (112. člen ZZK-1). Za obe navedeni zaznambi veljajo nekatera posebna pravila, zaradi česar nista uvrščeni v okvir določbe 111. člena ZZK-1, ki sicer na enem mestu ureja tipične zaznambe pravnega dejstva o javnopravnih omejitvah.

Konkretna javnopravna omejitev oziroma prepovedi zaradi nedovoljene gradnje lahko po veljavni zakonodaji dobi publicitetni učinek le z vpisom v zemljiško knjigo.

Če se prepoved ne nanaša na zemljiškoknjižnega lastnika temveč na imetnika druge pravice, se zaznamba vpiše pri pravici, na katero se prepoved nanaša (smiselno tretji odstavek 98. člena ZZK-1). Med drugimi (izvedenimi stvarnimi) pravicami pride $v$ poštev samo stavbna pravica. Nedovoljene gradnje se po naravi stvari (in najpogosteje) pojavljajo v zvezi z gradnjo objektov (oziroma zgradb). Če je nedovoljena gradnja izvršena na nepremičnini, ki je predmet lastninske pravice, se zaznamba prepovedi zaradi nedovoljene gradnje vpiše pri tej nepremičnini oziroma pri lastninski pravici na tej nepremičnini. V kolikor pa je nedovoljena gradna izvršena $v$ zvezi z zgradbo, katere lastninska pravica je vključena $\mathrm{v}$ stavbno pravico, se zaznamba prepovedi zaradi nedovoljene gradnje vpiše pri stavbni pravici. Z lastninsko pravico na zgradbi ni mogoče samostojno razpolagati, razpolagati je mogoče le s stavbno pravico, v katero je vključena 
lastninska pravica na zgradbi. Zato se lahko na primer prepoved razpolaganja, ki je ena izmed poglavitnih prepovedi pri nedovoljeni gradnji, nanaša samo na stavbno pravico.

Posebej je treba poudariti, da načelo zaupanja ne varuje dobrovernega kupca pred inšpekcijskimi ukrepi, izrečenimi z odločbo pri nelegalni in neskladni gradnji. Dobroverni kupec se tudi ne more sklicevati na dejstvo, da zaradi tega, ker ni bilo zaznambe $\mathrm{v}$ zemljiški knjigi, inšpekcijskih ukrepov ni mogoče izvesti (Ekart, 2006:19). Vpisovanje javnopravnih omejitev v zemljiško knjigo praviloma nima oblikovalnih učinkov, ampak samo publicitetne. Drugače povedano, določena zaznamba, ki predstavlja javnopravno omejitev, ne nastane $\mathrm{z}$ vpisom $\mathrm{v}$ zemljiško knjigo (vpis takšne zaznambe $\mathrm{v}$ zemljiško knjigo nima oblikovalnih učinkov), ampak s sprejetjem splošnega akta (na primer Odlok o razglasitvi Kraške kulturne krajine v Lipici za kulturni spomenik državnega pomena) ali s pravnomočnostjo oz. dokončnostjo upravne odločbe (na primer odločba o prepovedih zaradi nedovoljene gradnje). Prav tako je treba ugotoviti, da je večina javnopravnih omejitev razvidna iz potrdila o namenski rabi zemljišča (prej 105. člen ZPNačrt, sedaj 260. člen ZUreP-2), pri čemer mora posebne režime, ki veljajo za promet z nepremičninami, upoštevati notar pri overitvi zemljiškoknjižnega dovolila (38. člen v zvezi z drugim odstavkom 33. člena ZZK-1). Tiste javnopravne omejitve, ki ne izhajajo iz potrdila o namenski rabi zemljišča, se morajo zaradi zagotavljanja publicitete vpisovati v zemljiško knjigo z ustreznimi zaznambami. Če torej zakon glede pravnega dejstva obstoja nedovoljenega objekta ter neskladne uporabe objekta ne predvideva posebnega (in izrecnega) potrdila iz uradne evidence državnega organa, ki ima značaj javne listine, za katero velja domneva (presumptio iuris), da so podatki v njej resnični, si ni mogoče zamišljati, kako naj bi npr. notarji takšna pravna dejstva ugotavljajo ter pri izvajanju notarskih opravil upoštevajo, če to dejstvo ni vpisano v zemljiški knjigi z zaznambo prepovedi zaradi nedovoljene gradnje (Plavšak, Vrenčur, 2018: 22-27). 
Odločbo, s katero se izreče inšpekcijski ukrep po 93. členu GZ, pristojni gradbeni inšpektor nemudoma pošlje pristojnemu sodišču, to pa po uradni dolžnosti vpiše $\mathrm{v}$ zemljiško knjigo zaznambo $\mathrm{v}$ njej vsebovanih odredb in prepovedi ter ugotovljenih bremen po določbah tega zakona. ${ }^{14}$ Zaznamba se izbriše iz zemljiške knjige na predlog pristojnega gradbenega inšpektorja, lahko pa tudi na predlog inšpekcijskega zavezanca, če predlogu priloži potrdilo pristojnega gradbenega inšpektorja o izvršeni odločbi (glej tretji odstavek 94. člena GZ). V zvezi z izbrisom zaznambe prepovedi zaradi nedovoljena gradnje, je treba posebej opozoriti, da smiselna uporaba prvega in drugega odstavka 100. člena ZZK-1 ne prideta v poštev (kar smo že pojasnili zgoraj). Zaznamba prepovedi zaradi nedovoljene gradnje ni ovira za nadaljnje vpise v zvezi s prisilno prodajo ${ }^{15}$ (to velja tudi za zaznambo prepovedi odtujitve in obremenitve), vendar pa se zaznamba prepovedi zaradi nedovoljene gradnje ne izbriše, ko pride do vknjižbe lastninske pravice v korist novega lastnika, oziroma, ko pride do vknjižbe stavbne pravice v korist novega imetnika.

Glede učinkov zaznambe prepovedi zaradi nedovoljene gradnje, je treba smiselno uporabiti 99. člen ZZK-1. Če se zaznamba prepovedi nanaša na lastnika, je ovira za dovolitev naslednjih vpisov proti lastniku, ki bi začeli učinkovati po trenutku, od katerega učinkuje ta zaznamba:

1. vknjižbe pridobitve pravic na podlagi listin iz 1. oziroma 2. točke prvega odstavka 40. člena ZZK-1, če je bil podpis na zemljiškoknjižnem dovolilu overjen po trenutku, od katerega učinkuje zaznamba, oziroma če je bil notarski zapis sestavljen po tem trenutku,

2. predznambe pridobitve pravic na podlagi listin iz 2. do 4. točke prvega odstavka 49. člena ZZK-1,

\footnotetext{
${ }^{14}{ } \mathrm{~V}$ obravnavani zemljiškoknjižni zadevi je sodišče prve stopnje opravilo zaznambo prepovedi po uradni dolžnosti, na podlagi odločbe Inšpektorata RS za okolje in prostor. V konkretnem primeru gre za zaznambo kot vrsto vpisa, s katerim se opravi vpis oziroma izbris pravnih dejstev in ne za vknjižbo, s katero se vpisujejo pravice. Neuspešno je pritožbeno sklicevanje na nepravnomočnost in nedokončnost odločbe. Skladno s 159. členom ZGO-1 mora namreč pristojni gradbeni inšpektor odločbo sodišču poslati nemudoma, to pa po uradni dolžnosti vpiše $\mathrm{v}$ zemljiško knjigo zaznambo v njej vsebovanih odredb in prepovedi ter ugotovljenih bremen po določbah tega zakona. Upoštevaje določbo tretjega odstavka 146. člena ZGO-1, pritožba zoper odločbo, na katero se sklicuje pritožnik, ne zadrži njene izvršitve, kar pomeni, da je odločbo inšpektorja potrebno zaznamovati takoj po njenem prejemu, kot to določa prej citirani 159. člen ZGO-1. Glede na navedeno je sodišče prve stopnje, potem, ko je zemljiškoknjižni predlog prestal predhoden preizkus po 146. členu ZZK-1 v zvezi s 100.a členom ZZK-1, ravnalo pravilno, ko je po uradni dolžnosti dovolilo vpis zaznambe prepovedi, navedenih v citirani odločbi (VSK sklep CDn 8000000075/2011, 14.11.2011).«

${ }^{15} \mathrm{~V}$ poštev pride vknjižba lastninske pravice in stavbne pravice na podlagi pravnomočnega sklepa o izročitvi nepremičnine.
} 
3. zaznambe vrstnega reda za pridobitev lastninske pravice oziroma hipoteke (smiselno prvi odstavek 99. člena ZZK-1).

Če se zaznamba prepovedi nanaša na imetnika druge pravice (stavbne pravice), je ovira za dovolitev naslednjih vpisov, ki bi začeli učinkovati po trenutku, od katerega učinkuje ta zaznamba:

1. vknjižbe prenosa pravice, ki je predmet prepovedi, na podlagi listin iz 1. oziroma 2. točke prvega odstavka 40. člena ZZK-1, če je bil podpis na zemljiškoknjižnem dovolilu overjen po trenutku, od katerega učinkuje zaznamba prepovedi odtujitve in obremenitve, oziroma če je bil notarski zapis sestavljen po tem trenutku,

2. predznambe prenosa pravice, ki je predmet prepovedi na podlagi listin iz 2. do 4. točke prvega odstavka 49. člena ZZK-1 (smiselno drugi odstavek 99. člena ZZK-1).

\begin{tabular}{|c|c|}
\hline & \\
\hline $\begin{array}{l}\text { 158. člen } \\
\text { (posebne prepovedi) } \\
\text { (1) V zvezi z gradnjo, objektom ali } \\
\text { delom objekta, glede katerih je po } \\
\text { določbah tega zakona izrečen } \\
\text { inšpekcijski ukrep zaradi nedovoljene } \\
\text { gradnje, so prepovedana vsa za } \\
\text { legalne gradnje, legalne objekte sicer } \\
\text { dovoljena ali predpisana dejanja, zlasti } \\
\text { pa: } \\
\text { 1. izvedba komunalnih priključkov } \\
\text { na objekte gospodarske javne } \\
\text { infrastrukture, } \\
\text { 2. vpisi in spremembe vpisov } \mathrm{v} \\
\text { zemljiški knjigi, } \\
\text { 3. njegova uporaba ali opravljanje } \\
\text { gospodarskih ali drugih } \\
\text { dejavnosti v njem, } \\
\text { 4. promet z njimi ali z zemljiščem, } \\
\text { na katerem je in }\end{array}$ & $\begin{array}{l}\text { (posebne prepovedi) } \\
\text { (1) Za nedovoljen objekt in } \\
\text { neskladno uporabo objekta so glede } \\
\text { na vrsto gradnje prepovedana } \\
\text { naslednja dejanja: } \\
\text { 1. izvedba } \\
\text { priključkov na gospodarsko javno } \\
\text { infrastrukturo, } \\
\text { 2. vpisi in spremembe vpisov v } \\
\text { zemljiški knjigi, } \\
\text { 3. uporaba ali opravljanje } \\
\text { gospodarskih ali drugih dejavnosti, } \\
\text { 4. promet z njimi ali zemljišči, na } \\
\text { katerih so, } \\
\text { 5. overitve pogodb, sklepanje } \\
\text { pravnih poslov, sklenitev kreditnih, } \\
\text { zavarovalnih, najemnih, zakupnih, } \\
\text { delovršnih in drugih pravnih poslov } \\
\text { ter }\end{array}$ \\
\hline
\end{tabular}


5. sklepanje drugih pravnih poslov, kot sklenitev kreditnih, zavarovalnih, najemnih, zakupnih, delovršnih in drugih pravnih poslov med živimi.

(2) Prepovedi iz prejšnjega odstavka so obvezna sestavina odločbe, s katero se izreče inšpekcijski ukrep po določbah od 152. do vključno 155. člena tega zakona.

(3) Če je gradnja, glede katere je po določbah tega zakona izrečen inšpekcijski ukrep zaradi nedovoljene gradnje, na določeno vrsto gospodarske javne infrastrukture že priključena, pristojni gradbeni inšpektor $z$ odločbo tudi naloži upravljalcu takšne infrastrukture, da izvrši odklop. Če je gradnja, glede katere je po določbah tega zakona izrečen inšpekcijski ukrep zaradi nedovoljene gradnje, priklopljena preko legalne gradnje, se odklopi tudi takšna legalna gradnja.

(4) Prepovedi iz prvega odstavka ne veljajo, če so prepovedana dejanja potrebna zaradi izvršitve izrečenih inšpekcijskih ukrepov.

\section{9. člen}

\section{(vpis zaznambe prepovedi in možnost izbrisa)}

(1) Odločbo, s katero se izreče inšpekcijski ukrep po določbah od 152. do vključno 155. člena tega zakona, pristojni gradbeni inšpektor nemudoma pošlje pristojnemu
6. določitev hišne številke.

(2) Prepovedi iz prejšnjega odstavka se odredijo z odločbo, s katero se izreče inšpekcijski ukrep.

(3) Dovoljenja, soglasja, vpisi, pravni posli in drugi pravni akti, ki so $\mathrm{v}$ nasprotju s prvim odstavkom tega člena, so nični, razen če so predpisani ali odrejeni na podlagi tega zakona.

(4) Če je bila priključitev objekta na gospodarsko javno infrastrukturo izvedena, pristojni gradbeni inšpektor naloži upravljavcu, da ga odklopi. Če je nedovoljen objekt priključen na legalni objekt, se odklopi tudi ta objekt.

(5) Upravljavci, notarji, pooblaščeni inženirji s področja geodezije in druge osebe javnega ali zasebnega prava in drugi organi, pristojni za izvedbo dejanj iz prvega odstavka tega člena, morajo pred njihovo izvedbo preveriti, ali je za objekt izdano gradbeno dovoljenje, kadar je predpisano, in ali je $v$ zemljiški knjigi vpisana zaznamba o prepovedi $\mathrm{v}$ skladu s 94. členom tega zakona.

(6) Prepovedi iz prvega odstavka tega člena ne veljajo, če so dejanja potrebna zaradi izvršitve izrečenih inšpekcijskih ukrepov ali pridobitve dovoljenj in drugih predpisanih dejanj po tem zakonu.

\section{4. člen}

(vpis zaznambe inšpekcijskega ukrepa in možnost izbrisa) 
sodišču, to pa po uradni dolžnosti vpiše v zemljiško knjigo zaznambo $\mathrm{v}$ njej vsebovanih odredb in prepovedi ter ugotovljenih bremen po določbah tega zakona.

(2) Zaznamba iz prejšnjega odstavka se izbriše iz zemljiške knjige na predlog pristojnega gradbenega inšpektorja, lahko pa tudi na predlog inšpekcijskega zavezanca, če predlogu priloži potrdilo pristojnega gradbenega inšpektorja o izvršeni odločbi ali pravnomočno gradbeno dovoljenje.
(1) Gradbeni inšpektor, občinski inšpektor ali drug inšpektor, ki je izdal odločbo, s katero se izreče inšpekcijski ukrep $\mathrm{V}$ zvezi $\mathrm{z}$ nedovoljenim objektom ali neskladno uporabo objekta, nemudoma obvesti zemljiškoknjižno sodišče in priloži izvršljivo odločbo. Zemljiškoknjižno sodišče po uradni dolžnosti vpiše $\mathrm{v}$ zemljiško knjigo zaznambo izrečenega inšpekcijskega ukrepa in posebnih prepovedi iz prejšnjega člena. Inšpektor o izdaji odločbe obvesti tudi organ, ki vodi zemljiški kataster.

(2) Zemljiškoknjižno sodišče vpiše zaznambo iz prejšnjega odstavka $\mathrm{v}$ zemljiško knjigo tudi, če lastnik zemljišča ali objekta ni ista oseba kot inšpekcijski zavezanec. Zaznamba se vpiše pri vseh imetnikih lastninske ali stavbne pravice na nepremičnini.

(3) Zaznamba iz prvega odstavka tega člena se iz zemljiške knjige po uradni dolžnosti izbriše na podlagi obvestila pristojnega inšpektorja ali na predlog inšpekcijskega zavezanca, če ta predlogu priloži potrdilo inšpektorja, da se opravi izbris zaznambe. 
Potrdilo o namenski rabi zemljišča in zakonita predkupna pravica občine/države

Potrdilo o namenski rabi zemljišča je po novem urejeno v 260. členu ZUreP-2 ${ }^{16}$, zakonita predkupna pravica občine in države pa v 189. do 191. členu ZUreP-2. Potrdilo o namenski rabi (prej imenovano: lokacijska informacija za promet $z$ nepremičninami) vsebuje podatek o namenski rabi prostora (namenska raba je s prostorskim aktom določena raba zemljišč in objektov; na primer kmetijsko zemljišče, stavbno zemljišče in podobno), kot jo določa občinski prostorski načrt, ter podatek o prostorskih ukrepih za zavarovanje prostorskega načrtovanja in predkupni pravico občine. Potrdilu se lahko priloži tudi kopijo grafičnega dela občinskega prostorskega načrta.

Potrdilo o namenski rabi zemljišča je obvezna priloga pri prometu z nepremičninami glede na 38. člen ZZK-1. Kot obvezna priloga pride v poštev takrat, ko se z zemljiškoknjižnim dovolilom dovoljuje vknjižba lastninske pravice in ne glede na to, ali gre za prodajo nepremičnine ali za razpolaganje na temelju drugega zavezovalnega pravnega posla (menjalna pogodba, darilna pogodba, izročilna pogodba, preužitna pogodba). Izjema velja za prodajo posameznih delov v etažni lastnini, kjer potrdilo o namenski rabi zemljišča ni potrebno (četrti odstavek 38. člena ZZK-1). Prav tako je izključeno uveljavljanje zakonite predkupne pravice po ZUreP-2 pri prodaji posameznega dela v etažni lastnini.

Potrdilo o namenski rabi zemljišča velja do uveljavitve sprememb in dopolnitev občinskega prostorskega načrta ali državnega prostorskega načrta. Če se za zemljišče, na katerega se potrdilo nanaša, pripravljajo spremembe in dopolnitve občinskega prostorskega načrta ali državnega prostorskega načrta, je to potrebno v potrdilu posebej navesti. ${ }^{17}$ Potrdilo o namenski rabi zemljišča ima značaj

${ }^{16}$ V 260. členu ZUreP-2 je določeno sledeče: »(1) Potrdilo o namenski rabi zemljišča vsebuje podatek o namenski rabi prostora, kot jo določa OPN, ter podatek o začasnih ukrepih za zavarovanje prostorskega načrtovanja in predkupni pravici občine. Potrdilu o namenski rabi zemljišča se lahko priloži tudi kopija grafičnega dela OPN. (2) Če se za zemljišče, na katero se potrdilo nanaša, pripravljajo spremembe prostorskega akta, je to treba v potrdilu posebej navesti.«

(3) Potrdilo o namenski rabi zemljišča izda občina. Ima naravo potrdila iz uradne evidence in se izda skladno s predpisi o upravnem postopku proti plačilu upravne takse.

${ }_{17}$ Zakonita predkupna pravica občine predstavlja prostorski ukrep (tovrstni prostorski ukrepi so po veljavni zakonodaji urejeni v ZUreP-2). Tudi če bi pristojna občinska služba objavila v potrdilu o namenski rabi zemljišča, da se pripravljajo sprememba in dopolnitve prostorskih ukrepov, ter da bo zaradi tega neka nepremičnina, v zvezi s katero se izdaja potrdilo o namenski rabi, $\mathrm{v}$ prihodnje »obremenjena« $\mathrm{z}$ zakonito predkupno pravico občine, to ne more preprečevati pravnega prometa z nepremičnino. Vse dotlej, dokler tak prostorski ukrep ne stopi v veljavo, ne more imeti pravnih učinkov na promet $\mathrm{z}$ nepremičnino. $V$ nasprotnem bi to predstavljalo ustavnopravno sporen (nedopusten) poseg $\mathrm{v}$ lastninsko pravico. Takšno poseganje $\mathrm{v}$ tako imenovano razpolagalno upravičenje lastnika (prodajalca nepremičnine) že $\mathrm{v}$ času, ko prostorski ukrep 
potrdila iz uradne evidence in se izda skladno s predpisi o upravnem postopku ter proti plačilu upravne takse, kot je s predpisi, ki urejajo upravne takse, določeno za potrdila, ki jih izdajajo organi na podlagi uradnih evidenc.

Ker je potrdilo o namenski rabi zemljišča potrdilo iz uradne evidence, ima značaj javne listine ter zanj velja domneva (presumptio iuris), da so podatki v njem resnični. Ti podatki torej uživajo javno zaupanje. ${ }^{18} \mathrm{~S}$ tem se je $\mathrm{v}$ našem pravu uveljavil institut »zaupanja potrdilo o namenski rabi zemljišča«. Govorimo lahko torej o načelu zaupanja $\mathrm{v}$ potrdilo o namenski rabi zemljišča. Če poštena (dobroverna) stranka pridobi potrdilo o namenski rabi zemljišča, iz katerega pa ne izhaja prostorski ukrep zakonite predkupne pravice, jo pravo (na podlagi načela zaupanja $\mathrm{v}$ potrdilo iz uradne evidence, ki ima značaj javne listine) varuje $\mathrm{v}$ tem pomenu, da ima prednost pravni promet z nepremičnino. Čeprav morda $\mathrm{v}$ resnici obstaja zakonita predkupna pravica občine, ki pa ni bila objavljena oz. razvidna iz potrdila o namenski rabi zemljišča, prodajna pogodba ni nična. Stranka je s tem, ko je pridobila potrdilo o namenski rabi zemljišča ravnala zadosti skrbno. Večje stopnje skrbnosti od nje po naši oceni ni mogoče zahtevati. Zlasti pa ni mogoče od stranke zahtevati, da bi morala preverjati resničnost in popolnost podatkov, ki so navedeni $\mathrm{v}$ potrdilu o namenski rabi zemljišča, s pregledovanjem občinskih odlokov. Pomen potrdila o namenski rabi zemljišča je ravno ta, da organ javno sporoči na pregleden način podatek o namenski rabi prostora, kot jo določa občinski (ali državni) prostorski načrt, ter podatek o prostorskih ukrepih, določenih na podlagi predpisov s področja urejanja prostora (na primer podatek o zakoniti predkupni pravici občine oz. države).

\footnotetext{
določitve območja zakonite predkupne pravice še ne velja, je nedopustno. Od objave prihajajočih sprememb prostorskega ukrepa, pa vse do njegove uveljavitve, lahko preteče tudi daljše časovno obdobje, in če bi za to celotno obdobje že veljala »blokada prometnosti z nepremičnino«, bi s tem nedopustno posegali v lastninska upravičenja lastnika nepremičnine, ki želi s prodajo le-te uresničiti legitimen poslovni interes. V takem primeru tudi notar ne sme odreči overitve podpisa prodajalca na zemljiškoknjižnem dovolilu z utemeljitvijo, da je treba počakati na uveljavitev prostorskega ukrepa določitve območja zakonite predkupne pravice.

18 Glej 179. člen Zakona o splošnem upravnem postopku (Uradni list RS, št. 24/06 - uradno prečiščeno besedilo, 105/06 - ZUS-1, 126/07, 65/08, 8/10 in 82/13).
} 


\begin{tabular}{|c|c|}
\hline 105. člen ZPNačrt & 260. člen ZUreP-2 \\
\hline $\begin{array}{l}\text { 105. člen } \\
\text { (potrdilo o namenski rabi } \\
\text { zemljišča) } \\
\text { (1) Potrdilo o namenski rabi zemljišča } \\
\text { vsebuje podatek o namenski rabi } \\
\text { prostora, kot jo določa občinski } \\
\text { prostorski načrt, ter podatek o } \\
\text { prostorskih ukrepih, določenih na } \\
\text { podlagi predpisov s področja urejanja } \\
\text { prostora. Potrdilu o namenski rabi } \\
\text { zemljišča se priloži tudi kopijo } \\
\text { grafičnega dela občinskega } \\
\text { prostorskega načrta. } \\
\text { (2) Potrdilo o namenski rabi zemljišča } \\
\text { velja do uveljavitve sprememb in } \\
\text { dopolnitev občinskega prostorskega } \\
\text { načrta ali državnega prostorskega } \\
\text { načrta. Če se za zemljišče, na katerega } \\
\text { se potrdilo nanša, pripravljajo } \\
\text { spremembe in dopolnitve občinskega } \\
\text { prostorskega načrta ali državnega } \\
\text { prostorskega načrta, je to potrebno v } \\
\text { potrdilu posebej navesti. } \\
\text { (3) Potrdilo o namenski rabi zemljišča } \\
\text { ima značaj potrdila iz uradne evidence } \\
\text { in se izda skladno s predpisi o } \\
\text { upravnem postopku ter proti plačilu } \\
\text { upravne takse, kot je s predpisi, ki } \\
\text { urejajo upravne takse, določena za } \\
\text { potrdila, ki jih izdajajo organi na } \\
\text { podlagi uradnih evidenc, pri čemer } \\
\text { posamična zemljiška } \\
\text { predstavlja en zahtevek. } \\
\text { (4) Z dnem uveljavitve tega zakona ne } \\
\text { glede na določbe drugih predpisov } \\
\text { predložitev lokacijske informacije ali }\end{array}$ & $\begin{array}{l}\text { 260. člen } \\
\text { (potrdilo o namenski rabi } \\
\text { zemljišča) } \\
\text { (1) Potrdilo o namenski rabi zemlijšča } \\
\text { vsebuje podatek o namenski rabi } \\
\text { prostora, kot jo določa OPN, ter } \\
\text { podatek o začasnih ukrepih za } \\
\text { zavarovanje prostorskega načrtovanja } \\
\text { in predkupni pravici občine. Potrdilu } \\
\text { o namenski rabi zemljišča se lahko } \\
\text { priloži tudi kopija grafičnega dela } \\
\text { OPN. } \\
\text { (2) Če se za zemljišče, na katero se } \\
\text { potrdilo nanaša, } \quad \text { pripravljajo } \\
\text { spremembe prostorskega akta, je to } \\
\text { treba v potrdilu posebej navesti. } \\
\text { (3) Potrdilo o namenski rabi zemliǰ̌ča } \\
\text { izda občina. Ima naravo potrdila iz } \\
\text { uradne evidence in se izda skladno s } \\
\text { predpisi o upravnem postopku proti } \\
\text { plačilu upravne takse. }\end{array}$ \\
\hline
\end{tabular}


potrdila o namenski rabi prostora ni več obvezna $\mathrm{v}$ nobenem postopku. Podatke za potrebe postopka si mora organ pridobiti sam. Lokacijska informacija ali potrdilo o namenski rabi prostora $z$ dnem uveljavitve tega zakona ni več pogoj za izvedbo enostavnih posegov $\mathrm{v}$ prostor.

\begin{tabular}{|c|c|}
\hline ZUreP-1 & ZUreP-2 \\
\hline $\begin{array}{l}\text { Drugi razdelek: ZAKONITA } \\
\text { PREDKUPNA PRAVICA } \\
\text { OBČINE } \\
\text { 85. člen } \\
\text { (območje predkupne pravice) } \\
\text { (1) Občina lahko z odlokom določi } \\
\text { območje predkupne pravice občine na } \\
\text { nepremičninah na celotnem območju } \\
\text { poselitve in na območju obstoječih } \\
\text { oziroma predvidenih infrastrukturnih } \\
\text { omrežij in objektovizven poselitvenih } \\
\text { območij ali na delu teh območij, če ni } \\
\text { s tem zakonom določeno drugače. } \\
\text { (2) Območje predkupne pravice mora } \\
\text { biti določeno tako natančno, da je } \\
\text { mogoče mejo območja prikazati v } \\
\text { zemljiškem katastru in jo določiti v } \\
\text { naravi. }\end{array}$ & $\begin{array}{l}\text { 2. oddelek: Predkupna pravica } \\
\text { države in občine } \\
\text { 189. člen } \\
\text { (predkupna pravica) } \\
\text { (1) Občina lahko določi območje } \\
\text { predkupne pravice: } \\
\text { - na stavbnih zemljiščih; } \\
\text { - na ureditvenem območju naselja; } \\
\text { - na kmetijskih, gozdnih, vodnih in } \\
\text { drugih zemljiščih za namen graditve } \\
\text { objektov gospodarske } \\
\text { infrastrukture in objektov, ki se } \\
\text { uporabljajo za varstvo pred } \\
\text { naravnimi in drugimi nesrečami; } \\
\text { - na območju za dolgoročni razvoj } \\
\text { naselja, kot je določen v OPN. } \\
\text { (2) Država lahko določi območje } \\
\text { predkupne pravice na območju: } \\
\text { - izbrane variante iz uredbe o } \\
\text { najustreznejši varianti, } \\
\text { - veljavnega DPN ali } \\
\text { - uredbe o varovanem območju. } \\
\text { (3) Območje predkupne pravice } \\
\text { mora biti določeno tako, da ga je } \\
\text { možno grafično prikazati } \\
\text { zemljiškem katastru. }\end{array}$ \\
\hline
\end{tabular}


sorodniku v ravni vrsti, posvojitelju ali posvojencu;

7. če je kupec država, oseba javnega prava, ki jo je ustanovila država, ali izvajalec državne javne službe, kakor tudi investitor infrastrukture iz 91. člena tega zakona.

8.

\section{7. člen \\ (potrdilo)}

Lastnik nepremičnine na območju predkupne pravice ( $\mathrm{v}$ nadaljnjem besedilu: prodajalec) mora pred sklenitvijo kupoprodajne pogodbe pridobiti potrdilo občine, da na nepremičnini ne uveljavlja predkupne pravice. Če občina potrdila ne izda $\mathrm{v}$ 15 dneh od vložitve zahteve, se šteje, da predkupne pravice ne uveljavlja.

\section{8. člen}

\section{(ponudba občini)}

(1) Če občina $v$ roku iz prejšnjega člena izda potrdilo, da uveljavlja predkupno pravico, ji mora prodajalec podati pisno ponudbo za prodajo nepremičnine, o kateri se mora občina izjaviti najkasneje $\mathrm{v}$ petnajstih dneh, sicer se šteje, da nepremičnine ne bo kupila.

(2) Če občina ne uveljavlja predkupne pravice, lahko prodajalec proda nepremičnino drugi osebi, ko se je iztekel rok iz prejšnjega člena, vendar le pod enakimi ali zase ugodnejšimi pogoji, kot jih je ponudil občini.
(4) Območje predkupne pravice se določi z uredbo vlade ali odlokom občinskega sveta.

\section{0. člen}

\section{(izključitev predkupne pravice)}

(1) Občina ne more uveljavljati predkupne pravice:

- če lastnik proda ali podari nepremičnino solastniku, svojemu zakoncu ali osebi, s katero živi v zunajzakonski skupnosti, oziroma svojemu sorodniku $\mathrm{v}$ ravni vrsti, posvojitelju ali posvojencu;

- če je kupec država, oseba javnega prava, ki jo je ustanovila država, ali izvajalec državne javne službe, kakor tudi investitor gospodarske javne infrastrukture ali

- pri prodaji etažne lastnine, razen $\mathrm{v}$ primeru prenove po tem zakonu.

(2) Država ne more uveljavljati predkupne pravice $\mathrm{v}$ primerih iz prve in tretje alineje prejšnjega odstavka.

\section{1. člen}

\section{(pravice in obveznosti oseb, vključenih $\mathbf{v}$ prodajo)}

(1) Lastnik zemljišča, ki se nahaja $\mathrm{v}$ območju predkupne pravice po tem zakonu, mora zemljišče pred prodajo najprej ponuditi $\mathrm{v}$ odkup državi ali občini kot nosilcu predkupne pravice. Nosilec predkupne pravice se o sprejetju ali zavrnitvi ponudbe izjavi v 15 dneh od njenega sprejetja, sicer se šteje, da ponudbe ne 


\section{9. člen \\ (pogodba)}

(1) Notar ne sme overiti podpisa prodajalca na kupoprodajni pogodbi, če prodajalec ne predloži potrdila iz 87. člena oziroma izjave iz 88. člena tega zakona, da občina ne uveljavlja predkupne pravice oziroma, da ni zainteresirana za nakup nepremičnine. (2) V primeru prodaje nepremičnine, na kateri obstaja predkupna pravica, mora pred overitvijo podpisa prodajalec notarju predložiti pisno ponudbo, ki jo je poslal občini. Notar ne sme overiti podpisa na pogodbi, ki je bila sklenjena pod za kupca ugodnejšimi pogoji, kot jih je lastnik ponudil občini in če listina nima vseh obveznih sestavin pogodbe, ter zaradi tega ni sposobna za vpis $\mathrm{v}$ zemljiško knjigo.

(3) Če prodajalec izjavi, da občina v roku iz 87. člena tega zakona ni izdala potrdila, da na nepremičnini ne obstaja predkupna pravica oziroma, da se $\mathrm{v}$ roku iz prvega odstavka prejšnjega člena občina ni izjavila, predloži dokazilo o tem, da je vložil zahtevo za izdajo potrdila, oziroma občini podal ponudbo za odkup nepremičnine. Notar mora pred overitvijo podpisa preveriti, ali je bila zahteva vložena in ali občina res ni izdala potrdila oziroma se izjavila $\mathrm{v}$ predpisanem roku. sprejema. $\mathrm{V}$ tem primeru lahko lastnik zemljišče proda drugi osebi, pri čemer pa cena ne sme biti nižja od tiste, ki je bila ponujena nosilcu predkupne pravice. Prodajalec se o ponudbi in pogojih prodaje, vsebovanih $\mathrm{v}$ ponudbi, $\mathrm{z}$ nosilcem predkupne pravice ni dolžan pogajati.

(2) Določba prejšnjega odstavka o višini cene za prodajo zemljišča drugi osebi veže prodajalca še dva meseca po tem, ko je zemljišče ponudil v odkup nosilcu predkupne pravice, vendar pa mora po preteku tega roka zemljišče z enako ali drugačno ceno zopet najprej ponuditi v odkup temu nosilcu predkupne pravice.

(3) Če gre za prodajo kmetijskega zemljišča, gozda ali kmetije in občina ali država ne uveljavlja predkupne pravice, poteka prodaja kmetijskega zemljišča, kmetije ali gozda skladno z določbami zakona, ki ureja kmetijska zemljišča, in zakona, ki ureja gozdove.

(4) Prodajalec mora notarju predložiti:

- izjavo nosilca predkupne pravice, da ne sprejema njegove ponudbe, ali dokazila o tem, da je že preteklo 15 dni od njegove ponudbe in

- pisno ponudbo, ki jo je poslal nosilcu predkupne pravice.

(5) Pogodba, sklenjena v nasprotju z določbami tega poglavja, je nična. 
(4) Pogodba, sklenjena $\mathrm{v}$ nasprotju $\mathrm{z}$ določbami tega zakona o predkupni pravici občine, je nična.

\section{0. člen}

\section{(prodaja nepremičnine)}

Občina mora ob prodaji nepremičnine, ki jo je pridobila na podlagi uveljavitve predkupne pravice ali z razlastitvijo, zahtevati od kupca, da se zaveže, da bo v določenem roku zgradil objekt, določen $\mathrm{v}$ prostorskem aktu. Če kupec v določenem roku objekta ne izgradi, lahko občina pogodbo razdre. Sankcije za neizvršene pogodbene obveznosti kupec in občina določita $\mathrm{v}$ pogodbi.

\section{1. člen \\ (posebnosti)}

Občina lahko proda nepremičnino iz prejšnjega člena $s$ sklenitvijo neposredne pogodbe ali jo odda po predpisih $\mathrm{O}$ razpolaganju $\mathrm{s}$ premoženjem:

1. za gradnjo objektov za potrebe javne uprave, pravosodja, obrambe in državnih rezerv;

2. za gradnjo objektov gospodarske javne infrastrukture in objektov, ki služijo varstvu pred naravnimi in drugimi nesrečami;

3. za gradnjo objektov za potrebe zdravstva, socialnega varstva, šolstva, kulture, znanosti, športa;

4. za gradnjo socialnih in neprofitnih stanovanj; 
5. za rekonstrukcijo poškodovanih, dotrajanih ali porušenih objektov iz prve do četrte točke tega člena ter za prenovo območij iz 133. člena tega zakona;

6. za zemljišča, ki so potrebna za smotrno izkoriščanje ali zaokrožitev gradbenih parcel, na katerih so obstoječi objekti.

\section{Grajeno javno dobro}

Po prvem odstavku 19. člena SPZ je javno dobro stvar, ki jo v skladu z njenim namenom ob enakih pogojih lahko uporablja vsakdo. Stvari pa so po prvem odstavku 15. člena SPZ samostojni telesni objekti, ki jih človek lahko obvladuje. Kljub temu, da ta definicija vključuje tudi premične stvari, lahko iz pravnih predpisov, ki urejajo javno dobro ugotovimo, da gre zgolj za nepremičnine (Krisper-Kramberger, 1998: IV).

Iz definicije 19. člena SPZ izhaja, da je poglavitni opredelilni element javnega dobra dejstvo, da ga lahko uporablja vsak. Takšno rabo imenujemo splošna raba (Juhart, Tratnik, Vrenčur, 2007: 73). Vendar splošna raba še ne pomeni, da gre za javno dobro. Neka omejena oblika splošne rabe je namreč lahko dopustna tudi na nepremičninah, ki niso (nujno) javno dobro. Tako se na primer lahko vsakdo sprehaja po gozdu, ter nabira gobe in gozdne sadeže, čeprav gozdovi praviloma niso javno dobro, ampak so pretežno v zasebni lasti.

Javno dobro ne pridobi tega statusa samodejno, na podlagi javne rabe, temveč le na podlagi izrecnega določila ustreznega pravnega akta, ki je lahko splošne ali posamične narave. Tako bomo $\mathrm{v}$ nadaljevanju govorili o javnem dobru kot o nepremičnini, ki je namenjena splošni rabi in ji je ustrezen pravni akt države ali lokalne skupnosti podelil status javnega dobra.

Za obravnavanje javnega dobra nas zanima predvsem socialna funkcija lastnine, kot jo opredeljuje 67. člen Ustave RS. Ko govorimo o socialni funkciji lastnine, imamo $\mathrm{v}$ mislih omejitve, ki jim je lastnik izpostavljen zaradi življenja $\mathrm{v}$ skupnosti. Pri obravnavi javnega dobra v sklopu lastninske pravice imamo opraviti z dvema, vsaj navidez nezdružljivima skrajnostima. $\mathrm{Na}$ eni strani je 
lastninska pravica, ki naj bi bila absolutna, na drugi strani pa obstajajo potrebe po normalnem funkcioniranju življenja, ki jih brez določenih splošno dostopnih stvari ni mogoče zadovoljiti (Krisper-Kramberger, 1998: IV). Zagotavljanje splošne dostopnosti pa nujno pomeni poseg v lastninsko pravico na teh stvareh.

Ustava RS je glede lastninske pravice na javnem dobru (ostala) neopredeljena (Krisper-Kramberger, 1998: IV). Osnovno izhodišče, ki se v tej zvezi postavlja je, da so predvsem država in občine tisti (ustrezni) pravni subjekti, za katere je primerno, da trpe tako izdatno utesnitev lastninske pravice, kot jo predstavlja status javnega dobra. Zato so lastniki javnega dobra država in občine. ${ }^{19}$ To pa seveda ne velja absolutno. Ne glede na različne interpretacije Ustave RS, Zakon o vodah (ZV-1) dopušča zasebno lastnino javnega dobra, ${ }^{20}$ tako da lahko ugotovimo, da je v našem pravu javno dobro lahko v lasti pravnih subjektov javnega ali zasebnega prava. Enako je stališče Upravnega sodišča. ${ }^{21}$ Ta ugotovitev je tudi v skladu splošnim konceptom ureditve lastninske pravice v našem pravu, kjer izhajamo iz enovitega koncepta lastninske pravice in ne poznamo več razlikovanja med »javno« in zasebno lastnino. Lastninska pravica je enovita in enaka ne glede na to ali je njen nosilec oseba javnega ali zasebnega prava. Hkrati pa moramo ugotoviti, da obstajajo nekatere stvari, ki so takšnega pomena, da morajo biti dostopne vsem, ne glede na to, kdo je njihov lastnik (Juhart, Tratnik, Vrenčur, 2007: 72).

Pri nekaterih kategorijah javnega dobra je javni interes tako močan, da zakon določa, da so lahko samo v lasti države ali lokalne skupnosti. Tako so vse javne ceste po Zakonu o cestah (ZCes-1) v lasti države ali občine (Juhart, Tratnik, Vrenčur, 2007: 74).

\footnotetext{
${ }^{19}$ Splošna raba pomeni za lastnika javnega dobra zelo daljnosežno omejitev njegove lastninske pravice, zato sta »idealna« lastnika javnega dobra vsekakor država in lokalna skupnost. Zlasti država ali lokalna skupnost je kot lastnica pripravljena na svojem predmetu lastninske pravice trpeti ravnanja drugih in privoliti $\mathrm{v}$ obsežne omejitve lastninske pravice.

${ }^{20}$ Glej peti odstavek 11. člena ZV-1.

${ }^{21}$ Sodba U 1230/2006: „Obravnavana parcela, ki je v naravi ribnik, ima status naravnega javnega dobra po samem zakonu. Vodno zemljišče je lahko v lasti osebe javnega ali zasebnega prava. Če je v lasti države, je izven pravnega prometa, če pa je v lasti drugih oseb, ima država predkupno pravico. Omejitev lastninske pravice z določitvijo predkupne pravice države ne pomeni prepovedi pravnega prometa v smislu 3. točke 1. odstavka 19. člena ZDen; « Sodba I Up 1822/2006: »Ni sporno, da imata sporni vodni zemljišči na podlagi ZV-1 status naravnega javnega dobra. Vendar status javnega dobra v nekaterih primerih ne pomeni, da stvar, ki je razglašena za javno dobro, ni v pravnem prometu oziroma na njej ni mogoče pridobiti lastninske pravice. Ker omenjeni nepremičnini ne spadata $\mathrm{v}$ prvi red voda, ki so naštete $\mathrm{v}$ prilogi ZV-1 in so po zakonu v lasti države (kar v zadevi niti ni sporno), je pravilno stališče sodišča prve stopnje, da zanju ne velja, da bi bili izven pravnega prometa."
} 
Splošna raba je vedno začasna in anonimna. Vendar pa dejstvo, da je javno dobro vsakomur dostopno, ne pomeni da je splošna raba neomejena. Način in obseg splošne rabe sta glede na naravo in namen posameznega javnega dobra različna. $\mathrm{Na}$ določenih vodah se na primer lahko uporablja plovila na motorni pogon, na drugih ne. Prav tako se spreminjata glede na tehnični napredek pri plovilih in vozilih. Dalje so javne ceste lahko namenjene samo določenih vrstam vozil (na primer motornim vozilom), oziroma je promet določenim vozilom po nekaterih javnih cestah prepovedan. Splošna raba javnega dobra je omejena tudi v tem smislu, da ga ne sme nihče uporabljati tako, da bi s svojo uporabo lahko druge izključil ali jim uporabo otežkočil. Prav tako so dovoljene omejitve splošne rabe zaradi varstva javnega reda in varnosti uporabnikov samih (na primer predpisi s področja varnosti cestnega prometa) (Berden et al., 2004: 126; KrisperKramberger, 1998: II).

Medtem, ko je splošna raba namenjena vsakomur, je posebna raba »subjektivna javna pravica«, ki pripada samo individualno določenemu upravičencu na podlagi posebnega upravnega dovolila, ki mora imeti podlago $\mathrm{v}$ zakonu. Možnost pridobitve pravice do posebne rabe izhaja tako iz 70. člena Ustave RS kot tudi iz tretjega odstavka 19. člena SPZ (Juhart, Tratnik, Vrenčur, 2007: 75; Berden et al., 2004: 129). Posebna pravica uporabe javnega dobra predstavlja $v$ bistvu pravni položaj, ko je dopustno ustanoviti na nepremičnini, ki je javno dobro bodisi obligacijsko pravico bodisi stvarno pravico. Nepremičnina, ki je javno dobro (70. člen Ustave RS; 19. člen SPZ), je praviloma izven pravnega prometa oziroma je njen promet znatno omejen. Toda kljub temu, da gre za javno dobro, je mogoče nepremičnino izkoriščati še na druge načine. Poleg splošne rabe, lahko služi tudi posebni rabi. Zaradi tega je $\mathrm{v}$ našem pravu tudi določeno, da je dopustna posebna pravica uporabe javnega dobra, če zakon tako določa. Tako bo na primer možen vpis posebne pravice uporabe na javnem dobru glede rabe naravnih vrednot na podlagi dovoljenja za posebno rabo ali akta o podelitvi koncesije s strani države ali lokalne skupnosti (glej 43. in 44. člen $\mathrm{ZON}$ ). Kot posebna pravica uporabe na javnem dobru se lahko vpisuje $\mathrm{v}$ zemljiško knjigo tudi stavbna pravica na javnem dobru (na primer podzemna garaža, ki je zgrajena pod javno cesto; glej 265. člen SPZ). Vendar pa se v tem primeru stavbna pravica, kot posebna pravica uporabe javnega dobra tehnično vpisuje tako kot sicer stvarna stavbna pravica (Vlahek et al., 2004: 1042). 
Naše pravo pozna dve vrsti javnega dobra: (1) naravno javno dobro in (2) grajeno javno dobro. Najpomembnejša razlika je $\mathrm{v}$ nastanku. Medtem ko naravno javno dobro nastane po naravni poti, nastane grajeno javno dobro s posegom $\mathrm{v}$ prostor. Status grajenega javnega dobra se pridobi z odločbo pristojnega organa države ali lokalne skupnosti. ZUreP-2 (tako kot prej ZGO-1) je eden izmed matičnih predpisov, ki urejajo pravni režim grajenega javnega dobra.

Pripravljalec predpisa je navedel, da določba 244. člena ZUreP-2 opredeljuje, kaj predstavlja splošno rabo javnih površin. Te so grajeno javno dobro, pri čemer pa je tako s splošno definicijo javnega dobra po SPZ, kot tudi z definicijo grajenega javnega dobra po tem zakonu splošna raba neopredeljena oziroma je prepuščena predpisu, ki opredeljuje posamezno vrsto grajenega javnega dobra. Ker je ta zakon (ZUreP-2) predpis, ki ureja javne površine, je v njem določeno, kakšna je splošna raba teh javnih površin, občini pa omogoča tudi predpisovanje posebne in podrejene rabe teh površin. Kot posebno kategorijo pa citirani člen opredeljuje tiste javne površine, ki so v zasebni lasti. Pojem »javne« namreč v tem kontekstu pomeni javno rabo in namen, ne pa lastništva. Javne površine $\mathrm{v}$ zasebni lasti $\mathrm{v}$ tem smislu so vseprisotne, sploh v bolj urbanih območjih pa si funkcioniranja naselij sploh ne da predstavljati. Pri tem gre za sobivanje javnega in zasebnega, pri čemer slednje na račun prvega ni omejeno ali izvotljeno do te mere, da bi lahko govorili o razlaščujoči rabi ali namenu, vendarle pa gre za omejitve zasebne lastnine, ki jo je treba ustrezno pravno urediti v kontekstu grajenega javnega dobra. Zakon zato določa, da je tovrstna raba možna na površinah, ki jih kot take določi občina in da se lahko izvršuje pod določenimi pogoji oziroma pravili. $\mathrm{V}$ kombinaciji z definicijo javnih površin iz 3. člena ZUreP-2, 244. člen ZUreP-2 torej opredeljuje dva osnovna parametra tega konkretnega grajenega javnega dobra: kaj so to javne površine in kakšna je njihova splošna raba, slednjo pa deli na rabo javnih površin $\mathrm{v}$ javni lasti, ki je v celoti odvisna od tega, kaj dovoljujejo predpisi, in splošno rabo javnih površin $\mathrm{v}$ zasebni lasti, ki je pogojena in omejena tudi z zasebnimi upravičenji. 22

${ }^{22}$ EVA: 2016-2550-0006, št.: 00719-49/2016/36 z dne 24. 5. 2017 - prva obravnava. 


\begin{tabular}{|c|c|}
\hline ZGO-1 & \\
\hline $\begin{array}{l}\text { 3. Grajeno javno dobro } \\
\text { 21. člen } \\
\text { (pogoji za pridobitev statusa } \\
\text { grajenega javnega dobra) } \\
\text { (1) Objekt oziroma del objekta, ki je } \\
\text { po določbah tega zakona lahko grajeno } \\
\text { javno dobro, pridobi status grajenega } \\
\text { javnega dobra državnega pomena z } \\
\text { ugotovitveno odločbo, ki jo na podlagi } \\
\text { sklepa Vlade Republike Slovenije po } \\
\text { uradni dolžnosti izda tisto pristojno } \\
\text { ministrstvo, v katerega delovno } \\
\text { področje sodi takšen objekt oziroma } \\
\text { pridobi status grajenega javnega dobra } \\
\text { lokalnega pomena z ugotovitveno } \\
\text { odločbo, ki jo na podlagi sklepa } \\
\text { pristojnega občinskega organa po } \\
\text { uradni dolžnosti izda pristojna } \\
\text { občinska uprava. } \\
\text { (2) Vlada Republike Slovenije oziroma } \\
\text { pristojni občinski organ izda sklep iz } \\
\text { prejšnjega odstavka na zahtevo, ki jo } \\
\text { lahko vloži pristojni resorni minister } \\
\text { oziroma župan. Takšni zahtevi mora } \\
\text { biti priložena navedba določbe zakona } \\
\text { oziroma predpisa, v katerem je } \\
\text { podlaga, da lahko določena vrsta } \\
\text { objekta oziroma njegovega dela } \\
\text { pridobi status grajenega javnega dobra, } \\
\text { uporabno dovoljenje, kadar je to } \\
\text { predpisano in ustrezen zemljiško- } \\
\text { katastrski načrt z vrisanim objektom, } \\
\text { izdelan v skladu z geodetskimi } \\
\text { predpisi. } \\
\text { (3) Ugotovitvena odločba o pridobitvi }\end{array}$ & $\begin{array}{l}\text { 6. poglavje: RABA JAVNIH } \\
\text { POVRŠIN IN GRAJENO } \\
\text { JAVNO DOBRO } \\
\text { 244. člen } \\
\text { (splošna in posebna raba javnih } \\
\text { površin) } \\
\text { (1) Splošna raba javnih površin je } \\
\text { raba, ki je namenjena prostemu } \\
\text { gibanju oseb, predvsem za namene } \\
\text { prehoda in dostopa do drugih javnih } \\
\text { površin, zelenega sistema, bivališč, } \\
\text { poslovnih objektov ter gospodarske } \\
\text { javne infrastrukture in družbene } \\
\text { infrastrukture, ter rekreaciji, igri in } \\
\text { drugim prostočasnim aktivnostim na } \\
\text { prostem. } \\
\text { (2) Splošna raba javnih površin v } \\
\text { javni lasti se izvaja skladno z } \\
\text { namenom ter pod pogoji in } \\
\text { omejitvami, kot jih določa zakon } \\
\text { oziroma predpis, izdan na njegovi } \\
\text { podlagi. } \\
\text { (3) Občina lahko z odlokom } \\
\text { predpiše pogoje za posebno rabo } \\
\text { javnih površin. Posebna raba javnih } \\
\text { površin je raba, ki glede na vrsto } \\
\text { javne površine bistveno ne } \\
\text { zmanjšuje ali posega v splošno rabo } \\
\text { le-te, in s katero se na njej omogoča } \\
\text { trajno ali začasno izvajanje } \\
\text { gospodarskih in družbenih } \\
\text { dejavnosti, izvajanje posegov na } \\
\text { objektih, ki mejijo na javno } \\
\text { površino, in druge posege in } \\
\text { aktivnosti, kot na primer: } \\
\text { - postavitev gostinskih vrtov; }\end{array}$ \\
\hline
\end{tabular}


poleg sestavin, ki so po predpisu o splošnem upravnem postopku predpisane za pisno odločbo, $\mathrm{v}$ izreku vsebovati tudi navedbo številke parcele oziroma parcel in katastrske občine, na katere območju je zgrajen objekt oziroma del objekta, ki je pridobil status grajenega javnega dobra državnega oziroma lokalnega pomena. (4) Pristojno resorno ministrstvo oziroma pristojna občinska uprava pošlje pravnomočno ugotovitveno odločbo o pridobitvi statusa grajenega javnega dobra pristojnemu sodišču, ki po uradni dolžnosti vpiše $\mathrm{v}$ zemljiško knjigo zaznambo o javnem dobru.

\section{2. člen}

\section{(posledice pridobitve statusa} grajenega javnega dobra)

(1) Objekt oziroma njegov del, ki ima pridobljen status grajenega javnega dobra, mora njegov lastnik oziroma upravljalec vzdrževati $\mathrm{v}$ stanju, ki omogoča splošno rabo $\mathrm{v}$ skladu $\mathrm{z}$ njegovim namenom.

(2) $\mathrm{Na}$ objektu oziroma njegovem delu, ki ima pridobljen status grajenega javnega dobra, ni mogoče pridobiti lastninske ali kakšne druge stvarne pravice s priposestvovanjem, prav tako pa ne more biti predmet izvršbe.
- postaviter objektov, opreme in naprav za prodajo in oglaševanje izdelkov in storitev;

- postavitev polnilnih točk ter odjemnih in oddajnih mest za vozila; - postaviter gradbenih odrov in gradbišč;

- izvedbo javnih prireditev;

- izvedbo snemanj;

- prirejanje razstav.

\section{5. člen}

(postopek za pridobitev statusa grajenega javnega dobra)

(1) Status grajenega javnega dobra državnega pomena se pridobi $\mathrm{z}$ ugotovitveno odločbo, ki jo na podlagi sklepa vlade po uradni dolžnosti izda tisto pristojno ministrstvo, $\mathrm{v}$ katerega področje spada takšen objekt. Status grajenega javnega dobra lokalnega pomena se pridobi z ugotovitveno odločbo, ki jo na podlagi sklepa občinskega sveta po uradni dolžnosti izda občinska uprava.

(2) Vlada ali občinski svet izda sklep iz prejšnjega odstavka na zahtevo, ki jo lahko vloži pristojni resorni minister oziroma župan. Takšni zahtevi mora biti priložena navedba določbe zakona oziroma predpisa, $\mathrm{v}$ katerem je podlaga, da lahko določena vrsta zemljišča, objekta oziroma njegovega dela pridobi status grajenega javnega dobra, uporabno dovoljenje, kadar je to 
23. člen

(pogoji za ukinitev statusa

grajenega javnega dobra)

(1) Objektu oziroma delu objekta, ki ima pridobljen status grajenega javnega dobra državnega oziroma lokalnega pomena, se takšen status lahko odvzame z odločbo, ki jo na podlagi sklepa Vlade Republike Slovenije oziroma pristojnega občinskega organa po uradni dolžnosti izda tisti upravni organ, ki je status podelil.

(2) Vlada Republike Slovenije oziroma pristojni občinski organ izda sklep iz prejšnjega odstavka na zahtevo, ki jo lahko vloži pristojni resorni minister oziroma župan. Takšni zahtevi mora biti priložena obrazložitev nameravanega odvzema statusa grajenega javnega dobra in dokazilo, da nepremičnina oziroma njen del, ki ima pridobljen status grajenega javnega dobra, ne služi več namenu, zaradi katerega ji je bil dodeljen status.

(3) Ko postane odločba o ukinitvi statusa grajenega javnega dobra pravnomočna, jo pristojno resorno ministrstvo oziroma pristojna občinska uprava pošlje pristojnemu sodišču, ki po uradni dolžnosti iz zemljiške knjige izbriše zaznambo o javnem dobru.

(4) Status grajenega javnega dobra lahko preneha tudi, če je objekt oziroma njegov del, ki ima pridobljen status grajenega javnega dobra, v celoti uničen in ga ni mogoče obnoviti in je predpisano, in izpis iz zemljiškega katastra, katastra stavb ali katastra gospodarske javne infrastrukture.

(3) Pred izdajo odločbe iz prvega odstavka tega člena država ali občina na zemljišču, objektu ali njegovem delu pridobi lastninsko ali drugo ustrezno pravico, ki omogoča takšno splošno rabo, ki ustreza namenu pridobitve statusa grajenega javnega dobra in kot jo za pridobitev statusa grajenega javnega dobra določajo področni predpisi.

(4) Če v skladu s prejšnjim odstavkom za pridobitev statusa grajenega javnega dobra ni potrebna lastninska pravica države ali občine, se $v$ aktu, s katerim se pridobi druga ustrezna pravica, opredeli splošno rabo grajenega javnega dobra, pogoje in omejitve, ki jih iz tega naslova trpi lastnik, odškodnino zaradi omejitve lastninske pravice in vprašanje odgovornosti za škodo, nastalo pri splošni rabi grajenega javnega dobra.

(5) Ugotovitvena odločba o pridobitvi statusa grajenega javnega dobra mora vsebovati tudi navedbo številke zemljiške parcele oziroma parcel, na katere območju je zgrajen objekt oziroma del objekta, in številko objekta ali njegovega dela, ki je pridobil status grajenega javnega dobra državnega oziroma lokalnega pomena. 


zato onemogočena njegova splošna
raba ali pa, če se zgradi drug objekt, ki
pridobi status grajenega javnega dobra
z enakim namenom splošne rabe, kot
ga ima sedanji objekt oziroma njegov
del, ki ima pridobljen takšen status in
se ga zato lahko opusti. V takšnem
primeru Vlada Republike Slovenije
oziroma pristojni občinski organ izda
sklep iz prvega odstavka tega člena na
zahtevo, ki jo lahko vloži pristojni
resorni minister oziroma župan, če je
takšni zahtevi priložen zemljiško
katastrski načrt, izdelan v skladu z
geodetskimi predpisi, iz katerega
izhaja, da objekta ni več.

zato onemogočena njegova splošna raba ali pa, ce se zgradi drug objekt, ki pridobi sta za enakim namenom splošne rabe, kot ga ima sedanji objekt ozitoma njegov del, ki ima pridobljen takšen status in se ga zato lahko opusti. V takšnem primeru Vlada Republike Slovenije oziroma pristojni občnski organ izda zahtevo, ki jo lahko vloži pristojni resorni minister oziroma župan, če je takšni zahtevi priložen zemljiško katastrski načrt, izdelan v skladu $z$ izhaja, da objekta ni več.
(6) Pristojno resorno ministrstvo oziroma občinska uprava pošlje pravnomočno ugotovitveno odločbo o pridobitvi statusa grajenega javnega dobra pristojnemu sodišču, ki po uradni dolžnosti vpiše $\mathrm{v}$ zemljiško knjigo zaznambo o javnem dobrem.

\section{6. člen}

\section{(posledice pridobitve statusa} grajenega javnega dobra)

(1) Zemljišče, objekt ali njegov del, ki ima pridobljen status grajenega javnega dobra, mora njegov lastnik ali upravljavec vzdrževati v stanju, ki omogoča splošno rabo $\mathrm{v}$ skladu $\mathrm{z}$ njegovim namenom.

(2) $\mathrm{V}$ primeru iz tretjega odstavka prejšnjega člena se vlada ali občina $z$ lastnikom nepremičnine dogovori tudi o vzdrževanju njenega primernega stanja.

\section{7. člen}

\section{(prenehanje statusa grajenega javnega dobra)}

(1) Grajenemu javnemu dobru se status lahko odvzame smiselno po postopku iz 245. člena tega zakona.

(2) Status grajenega javnega dobra preneha, če je zemljišče, objekt oziroma njegov del v celoti uničen in ga ni mogoče obnoviti in je zato onemogočena njegova splošna raba.

(3) Status grajenega javnega dobra lahko preneha tudi, če se uredi 


\begin{tabular}{|l|l|}
\hline zemlišče ali zgradi drug objekt z \\
enakim namenom splošne rabe, \\
zaradi česar se status na prvotnem \\
lahko odvzame. \\
(4) Če raba grajenega javnega dobra \\
v zasebni lasti preseže namen \\
splošne rabe po tem zakonu in \\
pogoje in omejitve iz dogovora, \\
lahko lastnik zahteva bodisi odstop \\
od dogovora in ukinitev statusa \\
grajenega javnega dobra, bodisi \\
odškodnino, bodisi lahko državi ali \\
občini predlaga, da grajeno javno \\
dobro prevzame v last, razen če ta \\
predstavlja gradbeno parcelo \\
njegove stavbe.
\end{tabular}

\section{$5 \quad$ Problematika cest}

\subsection{Resnični primer}

Tožnik je vložil proti Občini in Republiki Sloveniji (RS) tožbo, s katero je zahteval od toženk odstranitev asfalta in bankine z dela cestišča javne ceste, $v$ delu, $v$ katerem je označen potek po zemljišču tožeče stranke, po skici terenske meritve geodetskega biroja..., na parcelah tožeče stranke, št. ... k.o. ..., in na tem delu zemljišča vzpostavitev prejšnjega stanja ter prepoved bodočega vznemirjanja. Okrajno sodišče je ugodilo zahtevku tožnika v razmerju do RS, zavrnilo pa zahtevek v razmerju do Občine. Zoper sodbo se je pritožila RS. Višje sodišče je pritožbi ugodilo in sodbo prve stopnje spremenilo tako, da je zavrnilo tudi tožbeni zahtevek tožnika proti RS.

Uredba o državnem prostorskem načrtu za rekonstrukcijo vinske ceste L 613 bi naj bila po mnenju Višjega sodišča zadostna podlaga za poseg $\mathrm{v}$ lastnino. Vzpostavitev prejšnjega stanja (odstranitev asfalta na tistih delih, kjer cesta poteka po nepremičnini tožnika) pa naj bi bila pretirana in $\mathrm{v}$ nasprotju $\mathrm{z}$ načelom sorazmernosti, saj so izpolnjeni pogoji za razlastitev in je do dejanske razlastitve že prišlo. 
Sodišče je kot nesporno ugotovilo, da vinska cesta L 613 poteka po nepremičninah tožnika. Celo sodišče samo ugotovi, da RS nedovoljeno posega v lastninsko pravico tožeče stranke, in sicer zaradi tega, ker se režim javnega dobra razteza tudi na nepremičnine tožnika, RS pa ni poskrbela za ustrezno pravno podlago za uporabo zasebnih zemljišča za potrebe vinske ceste (ker RS ni pridobila lastninske pravice na spornih nepremičninah s pravnim poslom oz. na podlagi zakonito izvedenega razlastitvenega postopka).

Zaradi poteka javne ceste po zemljišču v zasebni lasti je vzpostavljen konflikt med nosilcem javnega interesa, ki ga zastopa RS ter nosilcem zasebnega interesa, pojasnjuje Višje sodišče ter $\mathrm{v}$ nadaljevanju razloži vsebino načela sorazmernosti. Pravica tožeče stranke do zasebne lastnine iz 33. člena Ustave RS kot temeljna človekova pravica, se mora umakniti, ker bi bile z njenim neomejenim uresničevanjem ogrožene pravne dobrine, ki jih zahteva splošna družbena korist.

Tožeča stranka bi svoj interes lahko realizirala z uveljavljanjem odškodnine za odvzete nepremičnine, vendar RS vse do danes ni izvedla razlastitvenega postopka z obrazložitvijo, da s tožečo stranko ni prišlo do sklenitve pravnega posla o prenosu lastnine na spornih nepremičninah ter da je za to odgovorna izključno tožeča stranka.

RS pa pri tem očitno ne upošteva dejstva, da nepravdni postopek za določitev odškodnine sledi pred tem zakonito izvedeni razlastitvi; je torej le nadaljevanje razlastitvenega postopka. Ravnanje RS, ki onemogoča izpolnitev procesnih predpostavk, da bi tožeča stranka sploh lahko prišla do sodnega varstva ( $\mathrm{v}$ nepravdnem postopku za določitev odškodnine), predstavlja takšno nedopustno ravnanje, ki utemeljuje odgovornost RS tudi po splošnih pravilih o odškodninskih obveznostih (sodba III Ips 59/2010 z dne 7.9.2010). S tem stališčem je Vrhovno sodišče Republike Slovenije (VS) poskušalo sankcionirati nedopustno pravno stanje, ko lastniku zaradi dejanske razlastitve ostane le gola lastnina (nuda proprietas), nima pa ustreznega pravnega mehanizma za uveljavljanje odškodnine $\mathrm{v}$ nepravdnem postopku. Za takšne položaje je sodišče ponudilo dodatno pravno možnost, in sicer odškodninsko tožbo.

Za dopustno razlastitev mora zmeraj obstaja nesporno ugotovljen javni interes, ki jemlje pravilno izpeljani razlastitvi lastnost protipravnosti. Razlastitev pa je nezakonita, ko gre za t.i. obrnjeni razlastitveni postopek. Gre za primer, ko je lastniku dejansko odvzeta posest (in s tem onemogočena uporaba nepremičnine), 
še preden je bilo pravnomočno odločeno o razlastitvi. $V$ takšnih primerih je že nekdaj veljavni zakonu (drugi odstavek 55. člena Zakona o razlastitvi in prisilnem prenosu nepremičnin v družbeni lastnini - ZRPPN), ${ }^{23}$ kateremu je dala jasnejšo vsebino sodna praksa, kaznoval razlastitvenega upravičenca za obdobje nezakonitosti.

$\mathrm{Z}$ rekonstrukcijo vinske ceste, je prišlo do razširitve vinske ceste na slovensko ozemlje, kar je ugotovila tudi stalna slovensko-avstrijska komisija za mejo, ki je bila imenovana za obnovo in vnovično postavitev mejnih kamnov na državni meji. Komisija je predlagala, da naj bi poslej nova državna meja potekala po južni strani rekonstruirane vinske ceste, tako da se slovenska zemljišča, uporabljena za avstrijsko vinsko cesto, priključijo Avstriji. S tem se je zgodila razlastitev (zmanjšanje površine parcel) slovenskih lastnikov » korist avstrijske vinske ceste« (Demšar, 2011: 12-14).

V eni izmed odločb (II Ips 874/2009) je Vrhovno sodišče RS navedlo: »Ne glede na to, da obstoj splošnega interesa oziroma javne koristi $\mathrm{v}$ trenutku, ko je predlagateljica prevzela posest nepremičnin, med udeležencema ni sporen, je nezakonito njeno ravnanje, $\mathrm{s}$ katerim je sporni nepremičnini najprej vzela $\mathrm{v}$ posest in na njiju zgradila infrastrukturo (za potrebe mejnega prehoda), dvanajst let kasneje pa je bila izdana odločba o razlastitvi in uveden postopek za določitev odškodnine. Pravilno je stališče sodišča, da se pri določitvi višine odškodnine za razlaščeno nepremičnino ne upošteva vrednost tega, kar je razlastitveni upravičenec zgradil na nepremičnini.« Sodišče je v obrazložitvi še zapisalo: »Posledice takega ravnanja v pravnem redu niso izrecno urejene. Ustavno sodišče RS je že zavzelo stališče, da Ustava RS ne dopušča razlastitve na podlagi zakona, ampak le po izvedbi postopka, $\mathrm{v}$ katerem je $\mathrm{v}$ postopku s pravnimi sredstvi preizkušen obstoj javne koristi za razlastitev. Zavrnilo je tudi stališče, da bi bilo treba v primerih »dejanskih razlastitev«, se pravi razlastitev, v katerih je bila javna infrastruktura zgrajena, ne da bi bil prej izveden razlastitveni postopek, smiselno uporabiti 25. člen Zakona o temeljnih lastninskopravnih razmerjih - ZTLR, ki ureja (oz. je urejal) položaj graditelja in lastnika zemljišča v primeru graditeljeve

\footnotetext{
${ }^{23}$ Zakon o razlastitvi in prisilnem prenosu nepremičnin v družbeni lastnini - ZRPPN (Uradni list SRS, št. 5/80, $30 / 87$ in 20/89). V preteklosti je razlastitev urejal ZRPPN. Za njim je področje razlastitve in odškodnine urejal Zakon o stavbnih zemljiščih - ZSZ (Uradni list RS, št. 44/97), ki je med drugim določil, da z dnem uveljavitve ZSZ (25.7.1997) prenehajo veljati določbe ZRPPN (56. člen ZSZ). V drugem odstavku 53. člena pa je ZSZ določil, da se mzačeti postopki za določitev odškodnine po določbah Zakona o razlastitvi, končajo po dosedanjih predpisih«, tedaj po določbah ZRPPN (Sklep II Ips 386/99 z dne 25.5.2000). Danes urejata postopek razlastitve predvsem ZUreP-1 oz. ZUreP-2.
} 
nedobrovernosti. Tako razumevanje je po stališču Ustavnega sodišča RS, s katerim se Vrhovno sodišče strinja, v neskladju z Ustavo RS. Kadar obstajajo pogoji za odvzem ali omejitev lastninske pravice $v$ javnem interesu, jih lahko razlastitveni upravičenci uveljavljajo pod pogoji, ki jih določa zakonodaja, ki ureja tovrstne posege, in ni dovoljena analogna uporaba pravil, ki urejajo civilnopravna razmerja. Ustavno sodišče RS pa še ni zavzelo stališča, kako vrednotiti položaje »dejanskih razlastitev« v obdobju od dejanskega odvzema iz posesti do izvedbe razlastitvenega postopka.«

V konkretnem primeru se nam zdi ustrezna (pravična) rešitev ta, da se dejansko razlaščenemu lastniku $\mathrm{v}$ primerih nezakonitih razlastitev, ko razlastitveni upravičenec ne izvede zakonitega razlastitvenega postopka ter nerazumno dolgo vzdržuje nezakonito stanje, prizna pravno varstvo tudi s klasičnimi lastninskimi zahtevki (bodisi $\mathrm{z}$ reivindikacijskim bodisi $\mathrm{z}$ negatornim). Razlastitveni upravičenec bi v nasprotnem primeru lahko v nedogled vzdrževal protipravno stanje, lastnik pa ne bi imel ustreznega mehanizma za varstvo najbolj temeljne stvarne pravice na nepremičnini. V kolikor bi razlastitveni upravičenec na koncu le izvedel formalno pravilno in zakonito razlastitev, to še zmeraj ne bi pomenilo, da je bila dejanska razlastitev (v obdobju od protipravnega odvzema posesti pa do zakonite razlastitve) zakonita. Najmanj kar je, se takšnemu razlastitvenemu upravičencu kot civilna kazen odmerijo zakonske zamudne obresti, in sicer od dneva odvzema posesti pa vse do plačila odškodnine za razlaščeno nepremičnino. Takšna civilna sankcija ni prekomerna.

Vse navedeno je skladno s stališči ESČP o vsebini jamstva zasebne lastnine po 1. členu Protokola k Evropski konvenciji o človekovih pravicah - EKČP. Sodišče izhaja iz razlikovanja med primeri nedopustne razlastitve (zasegi), ki zahtevajo polno odškodnino, in primeri, ko je razlastitev sicer dopustna in ji za njeno zakonitost manjka le izplačilo odškodnine. V prvem primeru je prizadeta oseba upravičena do odškodnine, ki $\mathrm{v}$ največji možni meri odpravlja posledice nedopustnega ravnanja in vzpostavlja situacijo, ki bi po vsej verjetnosti obstajala, če nedopustnega ravnanja ne bi bilo. $V$ drugem primeru je ustrezna odškodnina $\mathrm{v}$ višini tržne vrednosti zemljišča $\mathrm{v}$ času odvzema posesti, valorizirana $\mathrm{z}$ namenom odprave učinkov inflacije $\mathrm{v}$ vmesnem obdobju in $\mathrm{z}$ obrestmi, predpisanimi za uporabo tujega denarja (glej odločbo II Ips 874/2009 z dne 16.09.2010). 
Višje sodišče je zavrnilo tožbeni zahtevek tožnika proti RS s sklicevanjem na načelo sorazmernosti. ${ }^{24}$ Sodišče na ta način naravnost podpihuje nezakonite razlastitve oz. obrnjene razlastitvene postopke.

Tožnik je bil mnenja, da so zaradi zagotovitve pravne varnosti in enotne uporabe prava izpolnjene predpostavke za dopuščeno revizijo v smislu 367.a člena Zakona o pravdnem postopku - ZPP. Višje sodišče je $z$ odločbo odstopilo od sodne prakse Vrhovnega sodišča RS (glej npr. sodbo, opr. št. III Ips 59/2010 z dne 7.9.2010). Tožnik (predlagatelj dopuščene revizije) je še trdil, da o pravnem vprašanju $\mathrm{v}$ resnici sploh ni sodne prakse VS.

Tožnik/predlagatelj je glede na vse navedeno predlagal Vrhovnemu sodišču RS, da dopusti revizijo proti pravnomočni sodbi Višjega sodišča glede naslednjega pravnega vprašanja:

\begin{abstract}
Ali lahko lastnik nepremičnine $v$ primeru, ko je bila njegova nepremičnina oz. del nepremičnine že uporabljen za gradnjo ali rekonstrukcijo ceste, ko torej obstoječa javna cesta poteka po nepremičnini oz. nepremičninah, ki so last pravnega subjekta (lastnika) zasebnega prava (in ne države ali občine), pri čemer razlastitveni upravičenec vzdržuje protipravno stanje na ta način, da ne izvede razlastitvenega postopka, uporabi za varstvo svoje lastninske pravice klasični lastninski zahtevek ${ }^{25} \mathrm{v}$ skladu s pravili Stvarnopravnega zakonika - SPZ, s katerim zahteva od razlastitvenega upravičenca odstranitev asfalta na tistem delu ceste, ki poteka po njegovi nepremičnini, in vzpostavitev prejšnjega stanja ter prepoved bodočega vznemirjanja lastnika.
\end{abstract}

\footnotetext{
${ }^{24}$ Pogoj javne koristi oziroma javnega interesa je temeljni pogoj, ki glede razlastitve oziroma nacionalizacije nastopa tako $\mathrm{v}$ nacionalnih pravnih redih kot tudi $\mathrm{v}$ mednarodnem pravu. Pri javni koristi gre za zelo splošen pojem, ki je $\mathrm{v}$ našem pravnem redu konkretiziran zlasti $\mathrm{v}$ 93. členu ZUreP-1, ki določa tako imenovane razlastitvene namene. Ustavno sodišče je $\mathrm{v}$ tej zvezi izpostavilo načelo sorazmernosti: »Javni interes, ki opravičuje odvzem ali omejitev lastninske pravice na nepremičninah, pa mora biti opredeljiv, stvarno upravičen in ustavno legitimen. Ukrepi za dosego cilja, temelječega na javnem interesu, morajo biti primerni in nujni. Izkazana pa mora biti tudi sorazmernost med posegom $\mathrm{v}$ lastninsko pravico in njegovimi učinki. Zato je razlastitev v našem pravnem sistemu, ki sledi zahtevam 69. člena Ustave RS, urejena tako, da je za konkretni primer, to je za konkretno zemljišče, treba $\mathrm{v}$ ustreznem postopku ugotoviti, ali so izpolnjeni z zakonom določeni pogoji za odvzem ali omejitev lastninske pravice v javno korist (US št. U-I-224/00).«

${ }^{25}$ Urejen v 92. in 99. členu Stvarnopravnega zakonika - SPZ.
} 


\subsection{Kako je v zgornjem primeru odločilo Vrhovno sodišče RS?}

Vrhovno sodišče RS je v nadaljevanju ugodilo reviziji in sodbo sodišča druge stopnje spremenilo tako, da je pritožbo Republike Slovenije zavrnilo in potrdilo sodbo sodišča prve stopnje. Pri tem je Vrhovno sodišče v sodbi VS, sodba II Ips 212/2013, 18.9.2014 še zapisalo:

Stališče Ustavnega sodišča, ki "zgolj« ugotavlja neskladnost odlokov o razlastitvi javnega dobra $z$ URS in jih ne razveljavlja, ne pomeni, da je lastnik zemljišča že kar izgubil lastninsko pravico in njeno sodno varstvo, kljub ugotovitvi, da bi lahko razveljavitev $z$ ustavo neskladnih odlokov povzročilo še bolj protiustavno stanje od dejanske razlastitve. Celo nasprotno, iz razlogov odločb sodišča je jasno razvidno, da je treba odvzem lastninske pravice šele opraviti na enega od zakonsko predpisanih načinov (sporazum ali razlastitveni postopek). Čim je tako, pa do tedaj lastninska pravica "živi« brez omejitev, torej $z$ vsemi upravičenji: ius utendi, fruendi et abutendi. Nasprotna razlaga bi odvzela težo, logiko in pomen omenjenim ustavnopravnim argumentom. Dopuščala bi protislovno razlago, da čeprav je treba lastninsko pravico šele prenesti na drugega titularja - razlastitvenega upravičenca, je kljub temu dolžan aktualni titular zaradi dejanskih okoliščin (sprejema neustavnega akta in posledičnega fizičnega posega $\mathrm{v}$ nepremičnino), ki ne predstavljajo pravne podlage za poseg $\mathrm{v}$ lastninska upravičenja, trpeti prikrajšanja pri njeni uporabi in uživanju oziroma protipravne posege $v$ ti upravičenji.

Iz obrazložitve:

Sodišče prve stopnje je zavrnilo tožbeni zahtevek zoper prvo toženo stranko, zoper drugo toženo stranko pa je ugodilo tožbenemu zahtevku in ji naložilo, da je dolžna odstraniti asfalt in bankine $\mathrm{z}$ dela cestišča javne ceste $\mathrm{v}$ delu, ki glede na skico terenske meritve poteka po tožnikovem zemljišču, ter da mora vzpostaviti prejšnje stanje z zasutjem zemlje in posaditvijo trave. Ugotovilo je, da gre za Cesto A., ki je javno dobro v upravljanju druge tožene stranke - države, da pa ta cesta deloma poteka tudi po nepremičninah tožeče stranke, ustrezen razlastitveni postopek pa ni bil nikoli sprožen. Poudarilo je zato še, da je druga tožena stranka s tem, ko je sprejela uredbo o rekonstrukciji Vinske ceste, ki jo je sicer izvršila Republika Avstrija, ki to cesto $\mathrm{v}$ celoti vzdržuje, neutemeljeno posegla $\mathrm{v}$ lastninsko pravico. 
Sodišče druge stopnje je ugodilo pritožbi druge tožene stranke in je odločitev sodišča prve stopnje spremenilo tako, da je tožbeni zahtevek zavrnilo. Poudarilo je, da se morajo lastninskopravna upravičenja umakniti uveljavitvi javne koristi, da bi ugoditev zahtevku pomenila poseg v substanco Vinske ceste in da tožeča stranka lahko zaradi »dejanske« razlastitve zahteva ustrezno nadomestilo oziroma odškodnino. Sklicuje se tudi na odločbo Ustavnega sodišča U-I-256/04, ki v tovrstnih primerih dejanskih razlastitev na podlagi predpisa ni razveljavila občinskega odloka o razlastitvi zemljišča za javno dobro brez opravljenega razlastitvenega postopka, temveč le ugotovila njeno neskladje z Ustavo, kot tudi na v skladu s to odločbo sprejeto odločbo Vrhovnega sodišča III Ips 59/2010 z dne 7. 9. 2010, ki povzema njene razloge v smeri, da bi razveljavitev tovrstnih odlokov pomenila še bolj protiustavno stanje, kot je podano v primerih dejanske razlastitve.

Revizijsko sodišče je s sklepom II DoR 45/2013 z dne 18. 4. 2013 odločilo o tožnikovem predlogu za dopustitev revizije in revizijo dopustilo glede vprašanja, ali lahko lastnik nepremičnine, ki je uporabljena za gradnjo ali rekonstrukcijo ceste, razlastitveni upravičenec pa ne zahteva uvedbe postopka razlastitve, za varstvo lastninske pravice uporabi klasične zahtevke za varstvo lastninske pravice po določbah Stvarnopravnega zakonika (v nadaljevanju SPZ), v obravnavanem primeru negatornega.

\subsection{Kakšna je ostala sodna praksa?}

VS, sklep II Ips 188/2013, 16.7.2015:

Tožnik ni bil dolžan trpeti prikrajšanja svoje lastninske pravice, ko je javna cesta potekala po njegovi nepremičnini, dokler formalni postopek razlastitve ni bil izveden. Lahko bi vložil stvarnopravno tožbo (primerjaj sodbo VS RS II Ips 212/2013 z dne 18. 9. 2014), s katero bi zahteval, da druga toženka na lastne stroške prestavi javno cesto, ki poteka po njegovi nepremičnini, na katastrsko določeno traso javne ceste, ali odškodninsko tožbo zaradi zmanjšanja vrednosti svoje nepremičnine (primerjaj sodbo VS RS III Ips 59/2010 z dne 7. 9. 2010). Ker se je prva toženka strinjala s prestavitvijo ceste, tožnik ni ravnal protipravno, ko je, brez da bi se poslužil sodnega varstva, organiziral prestavitev ceste sam. Občina za zadovoljevanje potreb svojih prebivalcev gradi, vzdržuje in ureja lokalne javne ceste in javne poti (drugi odstavek 21. člena ZLS). Zmotni so razlogi 
sodišča druge stopnje, da druga toženka ni obogatena $v$ višini stroškov izgradnja nadomestne javne ceste. Njena obogatitev se odraža $v$ prihranitvi njenega premoženja, ker je tožnik namesto nje izpolnil njeno zakonsko obveznost (197. člen v zvezi s prvim odstavkom 190. člena OZ).

Iz obrazložitve:

V obravnavanem primeru je bil tožnik vse do prestavitve ceste dejansko razlaščen, saj je občinska pot potekala po njegovih nepremičninah, ne da bi bil postopek razlastitve formalno izveden in ne da bi tožnik ali njegovi pravni predniki za to dobili kakršno koli odškodnino. Tako se postavlja vprašanje, kakšno pravno varstvo in možnosti je imel tožnik oziroma ali je bilo njegovo ravnanje, ko je sam organiziral prestavitev ceste, ki je potekala po njegovi nepremičnini, na katastrsko določeno traso, dopustno ter ali je dolžan sam nositi tudi finančne posledice svojega ravnanja.

V odločbi U-I-387/02 je Ustavno sodišče izreklo, da občina po ugotovitvi, da je posamezna javna cesta grajena na zemljišču, ki je v zasebni lasti, zgolj zaradi tega ne sme opustiti njene kategorizacije, ker je dolžna spoštovati predpisana merila za kategorizacijo javnih cest. Vrhovno sodišče je v zadevi III Ips 59/2010 z dne 7. 9. 2010 navedlo, da je določbo 19. člena ZJC-B treba razumeti kot možnost, da občina $v$ predpisanem postopku legalizira nastali protiustavni položaj, ki ga je povzročila z določitvijo tožnikovih nepremičnin za javno cesto. V nasprotju $z$ Ustavo in s temeljnimi načeli obligacijskega prava bi bila razlaga, po kateri bi tožena stranka lahko s svojo neaktivnostjo nesankcionirano vzdrževala protiustavno stanje. Možnosti tožene stranke, da v razlastitvenem postopku sanira posledice svojega nedopustnega ravnanja, v skladu s prepovedjo zlorabe pravic (7. člen OZ) ni mogoče uporabiti (zlorabiti) tako, da bi bila z njeno neuporabo oškodovanemu razlaščencu zaprta pot do odškodnine oziroma nadomestila zaradi posega $\mathrm{v}$ njegovo lastninsko pravico. Zato ima takšen dejansko razlaščen lastnik vse dokler formalna rąlastitev ni izvedena, pravico do odškodnine zaradi zmanjšanja svojega premoženja (izgube oziroma izničenja vsebine lastninske pravice na teh nepremičninah). V zadevi II Ips 212/2013 z dne 18. 9. 2014 pa je Vrhovno sodišče nadalje poudarilo, da v tovrstnih primerih dejanskih razlastitev ni izključeno niti stvarnopravno varstvo. Ker odvzem lastninske pravice še ni bil opravljen na enega od zakonsko predpisanih načinov (sporazum ali razlastitveni postopek), lastninska pravica do tedaj »živi« brez omejitev, torej z vsemi upravičenji: ius utendi, fruendi et abutendi. 
VS, Sodba X Ips 37/2015, 6.4.2016:

Za uvedbo postopka za razlastitev za namen gradnje ceste (1. točka prvega odstavka 93. člena ZUreP-1) mora biti javni interes izkazan na način iz tretjega odstavka istega člena $v$ zvezi s 109. členom ZPNačrt, to je z ustreznim prostorskim aktom.

VS, sodba II Ips 163/2013, 30.7.2015:

Zmotno je stališče pritožbenega sodišča, da je treba na zemljiščih, ki so del kategorizirane ceste, opredeljene kot javno dobro na podlagi Uredbe o kategorizaciji državnih cest in ležijo na zemljiščih $\mathbf{v}$ zasebni lasti, do ureditve lastninskih razmerij na cestah obdržati nespremenjeno stanje. Lastnik nepremičnin, po katerih poteka takšna cesta, ima namreč stvarnopravno varstvo in dejstvo, da je $\mathrm{v}$ teku zoper njega razlastitveni postopek, na to ne vpliva.

Iz obrazložitve:

Ustavno sodišče je že $\mathrm{v}$ številnih primerih kot protiustavne presodilo podzakonske predpise o kategorizaciji javnih cest, na podlagi katerih država ali lokalna skupnost brez predhodno izvedenih razlastitvenih postopkov posega $\mathrm{v}$ lastninsko pravico državljanov. Kategorizacija določene nepremičnine v zasebni lasti kot javne ceste, ne da bi bil pred tem z lastnikom sklenjen pravni posel za pridobitev teh zemljišč oziroma zakonito izveden razlastitveni postopek, je v nasprotju s 33. in 69. členom Ustave RS, zato sama po sebi ne more povzročiti prenosa lastninske pravice na teh zemljiščih. Odločilo je tudi, da država ali občina zaradi dejstva, da je bilo zemljišče uporabljeno za cesto, z vpisom javnega dobra (ceste) v zemljiško knjigo ne postaneta lastnici teh zemljišč. Kategorizacija javnih cest na zemljiščih $\mathrm{v}$ zasebni lasti torej sama po sebi ne more povzročiti prenosa lastninske pravice na teh zemljiščih. Glede kategorizacije je Ustavno sodišče še pojasnilo, da le-ta zgolj zaradi ugotovitve, da je posamezna javna cesta grajena na zemljišču, ki je v zasebni lasti, ne sme biti opuščena, saj je predpisana merila za kategorizacijo javnih cest treba spoštovati. V primeru da cesta izpolnjuje ta merila, je treba cesto ustrezno kategorizirati in s pravnim poslom ali po zakonito izvedenem razlastitvenem postopku pridobiti zemljišče, na katerem je cesta zgrajena, ali pa celo v primeru ugotovitve, da cesta ne izpolnjuje pogojev za kategorizacijo, v skladu z ZJC izpeljati postopek za ukinitev javne ceste. 
Navedeno pomeni, da lastninska pravica zaradi kategorizacije zemljǐšca ni prenehala in obstaja $z$ vsemi svojimi upravičenji še naprej. Kategorizacija je sicer mogoča, vendar na lastnino zemljišča ne vpliva. Lastnik zemljišča lastninsko pravico še vedno ima, zato mu pripada tudi njeno sodno varstvo. Dejstvo, da je $v$ teku zoper njega razlastitveni postopek, na to ne vpliva. Dokler lastnik zemljišča ni razlaščen po pravnomočno končanem razlastitvenem postopku, je še vedno lastnik in mu zato gre tudi stvarnopravno varstvo njegove lastninske pravice. Nasprotno stališče, kot ga je zavzelo pritožbeno sodišče, da je treba na teh zemljiščih do ureditve lastninskih razmerij na cestah obdržati nespremenjeno stanje, je nepravilno, saj ni v skladu $\mathrm{z}$ razlogi in pomenom iz navedenih odločb Ustavnega sodišča. Takšno stališče bi namreč pomenilo protislovno razlago, da mora lastnik zemljišč zaradi dejanskih protipravnih okoliščin (sprejema neustavnega akta in posledičnega fizičnega posega $\mathrm{v}$ nepremičnino) trpeti protipravne posege $\mathrm{v}$ uporabo in uživanje svojih nepremičnin. Lastniku bi v tem primeru ostala zgolj „gola“ pravica. Odrekanje stvarnopravnega varstva lastnikom teh zemljišč (in napotitev na uveljavitev odškodninske odgovornosti) bi tako pomenila legalizacijo dolgoletnega protipravnega stanja, kar bi bilo v nasprotju s samim bistvom pojma lastnine in njenega varstva.

VS, Sklep II DoR 265/2016, 8.12.2016:

Revizija se dopusti glede vprašanj:

- ali lahko lastnik nepremičnine, ki je bila uporabljena za gradnjo ali rekonstrukcijo ceste, razlastitveni upravičenec pa ne zahteva uvedbe postopka razlastitve, vloži zahtevek za varstvo svoje lastninske pravice na podlagi 99. člena SPZ;

- ali lahko ustno soglasje lastnika nadomesti postopek razlastitve; in

- ali je lahko cestna povezava, ki poteka delno po zasebnem zemljišču, po izvršeni kategorizaciji, za katero lastnik ni podal potrebnega soglasja ali dovoljenja (npr. Odlok o kategorizaciji občinskih cest v Občini Podčetrtek z dne 6. 7. 2000, Ur. 1. RS $71 / 2000$ - pot številka 817372 ), javna pot. 
VS, sodba II Ips 333/2013, 27.8.2015:

V primeru, ko gre za t. i. dejansko razlastitev, načeloma ni mogoče izključiti tožnikovega stvarnopravnega varstva $\mathrm{v}$ pravdnem postopku, če so zanj podani vsi elementi iz 99. člena SPZ: lastninska pravica tožnika, sam poseg in protipravnost takšnega posega.

Za odločitev v obravnavani zadevi je bistvena dejanska ugotovitev, da je tožnik poseg v svojo nepremičnino dovolil, zato v okoliščinah konkretnega primera sam poseg tožene stranke $\mathbf{v}$ tožnikovo nepremičnino (zaradi tožnikovega soglasja) ne predstavlja protipravnega ravnanja. Za ugoditev tožnikovemu zahtevku torej ni ovira ZCes-1, temveč tožnikovo soglasje.

Problematika urejanja drugih infrastrukturnih omrežij na podlagi služnosti v javno korist

\subsection{Uvod}

Služnost je v 210. členu SPZ opredeljena kot pravica uporabljati tujo stvar ali izkoriščati pravico oziroma zahtevati od lastnika stvari, da opušča določena dejanja, ki bi jih sicer imel pravico izvrševati na svoji stvari (služeča stvar). Tako oblikovana splošna opredelitev vsebine služnosti velja za vse vrste služnosti (stvarne, neprave stvarne, osebne služnosti in služnosti v javno korist). Služnosti učinkujejo na lastninsko pravico $\mathrm{v}$ odvisnosti od temeljnih materialnopravnih upravičenj, ki jih vključujejo. Služnost kot primarna izvedena stvarna pravica učinkuje na lastninsko pravico (osnovno pravico) služeče nepremičnine tako, da omejuje uresničevanje upravičenja uporabe (posesti, uporabe in/ali uživanja) stvari. Hkrati obremenjuje lastninsko pravico v pomenu, da je vsakokratni lastnik služeče nepremičnine dolžan dopustiti izvrševanje služnosti ter opuščati določena ravnanja, ki bi jih sicer kot lastnik lahko izvrševal (dopustitev in opustitev v pomenu negativnega izpolnitvenega ravnanja). Navedeno velja za vse vrste služnosti.

Služnosti v javno korist imajo značilnosti stvarnih in osebnih služnosti. Pogosto jih primerjamo z nepravimi stvarnimi služnostmi. V 226. členu SPZ je opredeljena »klasična, zasebna« neprava stvarna služnost na sledeči način: »Služnost, ki je po svoji vsebini stvarna služnost, se lahko ustanovi tudi v korist določene osebe. $\mathrm{V}$ teh primerih se glede nastanka in prenehanja uporabljajo določila tega zakona, ki urejajo osebne služnosti.« Klasična (zasebna) neprava 
stvarna služnost se ustanovi za doseganje zasebnih interesov njenega imetnika. Tako se na primer lahko ustanovi služnost pešpoti in voženj z osebnimi motornimi vozili v korist določene fizične osebe. Takšna služnost služi izključno zasebnim interesom konkretne fizične osebe, ki je njen imetnik. Ni prenosljiva in tudi ne podedljiva. Ker služi zasebnim interesom zgolj določene osebe (zadovoljevanju njenih osebnih potreb), preneha s smrtjo te fizične osebe. V kolikor pa je ustanovljena v korist pravne osebe, čas njenega trajanja ne sme biti daljši od trideset let (drugi odstavek 227. člena v zv. z 226. členom SPZ). Takšna pravna ureditev je posledica dejstva (kar je sicer skladno s pravno naravo klasičnih nepravih stvarnih služnosti), da imajo neprave stvarne služnosti dvojno pravno naravo. Pravno naravo stvarnih in osebnih služnosti. Značilnost pravih stvarnih služnosti je ta, da vključujejo upravičenje uporabe tuje (služeče) nepremičnine za potrebe uporabe gospodujoče nepremičnine. Obseg takšne uporabe služeče nepremičnine je praviloma ožji (na primer služnost poti), kot pri osebnih služnostih (na primer pri užitku). Ker pa se služnost, ki je po svoji vsebini stvarna služnost, lahko ustanovi v korist določene osebe (fizične ali pravne osebe), se glede njihovega nastanka in prenehanja uporabljajo tista pravila SPZ, ki urejajo osebne služnosti. V 227. členu SPZ je opredeljena osebna služnost kot pravica imetnika, da uporablja tujo stvar ali izkorišča pravico in traja najdlje do imetnikove smrti. Če je osebna služnost ustanovljena v korist pravne osebe, čas njenega trajanja ne sme biti daljši od trideset let. V 229. členu SPZ pa je določeno pravilo, da imetnik osebne služnosti ne more prenesti, lahko pa prenese njeno izvrševanje, če zakon (SPZ) tako določa. Služnosti v javno korist so po vsebini stvarne služnosti, ustanovljene pa so $\mathrm{v}$ korist določenih pravnih subjektov posebnih lastnosti. Ne ustanovijo se za doseganje zasebnih interesov njihovih imetnikov, temveč zaradi doseganja javne koristi (na primer postavitev, obratovanje in vzdrževanje energetske, elektronske komunikacijske, telekomunikacijske infrastrukture) (Plavšak, 2012: 10). Tako na primer sistemski operater določene vrste infrastrukture (operater omrežja za distribucijo električne energije) zagotavlja kot izvajalec gospodarske javne službe javne dobrine končnim uporabnikom. Javne dobrina lahko zagotavljajo država, občine ter druge pravne in fizične osebe, ki so izvajalci javnih služb.

Pomeni, da služnost v javno korist vključujejo predvsem upravičenje uporabe tuje nepremičnine, in sicer v korist obratovalca gospodarske javne infrastrukture (npr. postavitev (gradnja) objektov in naprav energetske infrastrukture ter položitev oziroma napeljava omrežja (določene vrste) energetske infrastrukture, vzdrževanje objektov in naprav ter nemoteno delovanje naprav in omrežij....). 
Prav tako služnost zagotavlja dostop do teh objektov, ki je potreben zlasti zaradi upravljanja, vzdrževanja in popravil. Pogosto je tudi omejena lastnikova pravica do uporabe zemljišča, na katerem stoji oziroma je položen infrastrukturni objekt. $\mathrm{Na}$ primer prepoved gradnje objektov in sajenja dreves $\mathrm{v}$ določenem (varovalnem) pasu plinovoda, daljnovoda ipd. Z vidika lastnika obremenjene nepremičnine pomeni služnost dopuščanje ravnanj drugega subjekta na nepremičnini ter opuščanje lastnih ravnanj, katerih mu kot lastniku sicer ne bi bilo potrebno opustiti (če služnost ne bi obstajala). Tipične služnosti v javno korist urejata zlasti EZ-126 in ZEKom-127. Upravičenec do služnosti v javno korist je praviloma operater omrežja gospodarske javne infrastrukture.

Glede na opisane pravne in dejanske značilnosti služnosti v javno korist, pravila, ki veljajo za klasične (zasebne) neprave stvarne služnosti (glede neprenosljivosti ter časovne omejenosti), niso primerna (in tudi ne veljajo) za služnosti v javno korist. Spet po drugi strani pa javnopravna narava teh služnosti terja reduciranje dopustnih pravnih temeljev pridobitve služnosti $\mathrm{v}$ javno korist $\mathrm{v}$ primerjavi $\mathrm{s}$ pozitivnimi (pravimi) stvarnimi služnostmi. Pravni temelji nastanka (pridobitve) pozitivnih (pravih) stvarnih služnosti so zakon (oziroma nastop pravnih dejstev, ki povzročijo izvirno pridobitev s priposestvovanjem); pravni posel in odločba državnega organa (glej 214. člen SPZ). V tem prispevku želimo utemeljiti tezo (ob upoštevanju in kritični analizi najnovejše sodne prakse), da priposestvovanje ni dopustni pravni temelj nastanka oziroma pridobitve služnosti v javno korist. $\mathrm{V}$ prispevku se ne ukvarjamo $\mathrm{z}$ vprašanjem prenosljivosti in časovne neomejenosti služnosti v javno korist (Plavšak, Vrenčur, 2016: 1407-1430).

\subsection{Pravni posel in odločba upravnega organa kot (edina?) pravna temelja pridobitve (nastanka) služnosti $v$ javno korist}

V skladu s četrtim odstavkom tedaj veljavnega 110. člena ZUreP-1 je moral upravičenec pred vložitvijo zahteve za prisilno ustanovitev služnosti $\mathrm{v}$ javno korist ponuditi lastniku nepremičnine, ki naj bi se s služnostjo obremenila, sklenitev pogodbe o ustanovitvi služnosti. Na popolnoma enak način je ta oblika nepopolne razlastitve urejena $\mathrm{v}$ sedaj veljavnem 211. členu ZUreP-2. Če se stranki nista sporazumeli, je lahko upravičenec predlagal prisilno ustanovitev

\footnotetext{
${ }^{26}$ Energetski zakon - EZ-1 (Uradni list RS, št. 17/2014).

27 Zakon o elektronskih komunikacijah - ZEKom-1 (Uradni list RS, št. 109/2012, 110/2013, 40/2014 - ZIN$\mathrm{B}$ in 54/2014 - odl. US).
} 
služnosti z upravno odločbo. ${ }^{28} \mathrm{~V}$ tem primeru je šlo za posebno vrsto razlastitvenega postopka, o čemer odloča upravni organ. Služnost nastane v trenutku, ko postane odločba pravnomočna (deveti odstavek 110. člena ZUreP1), ${ }^{29}$ vpis v zemljiško knjigo nima oblikovalnega (konstitutivnega) učinka.

Če se služnost v javno korist ustanavlja na podlagi pravnega posla, se za njen nastanek zahteva (poleg veljavnega pravnega posla, iz katerega izhaja obveznost ustanoviti služnost) še zemljiškoknjižno dovolilo in vpis v zemljiško knjigo.

$\mathrm{V}$ prvem in drugem odstavku 217. člena SPZ je urejeno (pravo in nepravo) priposestvovanje, ki pride $\mathrm{v}$ poštev kot pravni temelj pridobitve le za prave (pozitivne) stvarne služnosti. Po prvem odstavku 217. člena SPZ nastane stvarna služnost s priposestvovanje, če je lastnik gospodujoče stvari dejansko izvrševal služnost v dobri veri deset let. Predpostavke za pravo priposestvovanje so tri: dobra vera priposestvovalca; izvrševanje služnosti in potek desetletne priposestvovalne dobe. Pogoj dobre vere je izpolnjen, če je bila med lastnikom služeče nepremičnine in lastnikom gospodujoče nepremičnine sklenjena veljavna pogodba o ustanovitvi služnosti, služnost pa ni bila vpisana v zemljiški knjigi (Juhart et al., 2004: 902). Takšno stališče, ki dopušča zunajknjižno priposestvovanje, je sprejeto tudi $\mathrm{v}$ sodni praksi. ${ }^{30}$ Priposestvovalec $\mathrm{v}$ tem primeru ne more priposestvovati služnost $\mathrm{v}$ drugačnem obsegu, kot izhaja iz pravnega naslova, zlasti ne $\mathrm{v}$ obsegu (širšega) dejanskega izvrševanja, kot je dogovorjen s pogodbo. Nasprotno, pa lahko lastnik gospodujoče nepremičnine

\footnotetext{
${ }^{28}$ Ponudba za odkup nepremičnine je procesna predpostavka za začetek postopka prisilne ustanovitve služnosti (glej tudi 110. člen ZUreP-1 oz. 211. člen ZUreP-2 in 473. člen EZ-1).

${ }_{29}$ Nastanek služnosti povzroči že pravnomočna oblikovalna upravna odločba. Zaradi tega mora njen izrek vsebovati vse podatke, potrebne za opredelitev služnosti v javno korist (ID znak služeče nepremičnine, določen opis vsebine služnosti v javno korist, navedba osebe, v korist katere se ustanavlja, za katero vrsto infrastrukture se ustanavlja...). Glede teh podatkov velja smiselno enako, kot velja za vsebino zemljiškoknjižnega dovolila pri pravnoposlovnem načinu nastanka služnosti v javno korist.

${ }^{30}$ VS, sodba II Ips 75/2012, 18. 9. 2014: »Zavzemanje revidentke, da bi morala biti za obstoj dobrovernosti priposestvovalke stvarna služnost tudi vpisana v zemljiški knjigi, torej, da bi moralo biti predhodno izdano tudi ustrezno pisno zemljiškoknjižno dovolilo, pa pomeni materialnopravno zmotno odrekanje možnosti zunajknjižnega priposestvovanja tako na podlagi prej veljavne določbe prvega odstavka 54. člena ZTLR, ki ni ločila med pravim in nepravim priposestvovanjem, kot na podlagi od 1. 1. 2003 veljavnega prvega odstavka 217. člena SPZ, ki je to ločitev opravil in pri pravem - dobrovernem priposestvovanju skrajšal priposestvovalno dobo na deset let, pri nepravem priposestvovanju pa ohranil prejšnjo dvajsetletno priposestvovalno dobo. Revidentka se tako zavzema za prestrog standard tako za priposestvovanje (navedeni prvi odstavek 54. člena ZTLR), kot tudi za dobroverno priposestvovanje (navedeni prvi odstavek 217. člena SPZ), za katero je potrebna dobra vera priposestvovalca, izvrševanje služnosti in potek desetletne priposestvovalne dobe, za razliko od nepravega priposestvovanja služnosti iz drugega odstavka istega člena, za katero pa se ne zahteva dobra vera priposestvovalca, in pri kateri zadošča že, da se stvarna služnost dejansko izvršuje in da način izvrševanja ni nepošten. Revizijsko stališče, da bi morala biti služnostna pravica vpisana v zemljiški knjigi ob izkazani dobrovernosti torej pravno zmotno izključuje možnost pridobitve pravice na podlagi zunajknjižnega priposestvovanja, oziroma neutemeljeno negira ta stvarnopravni institut, kot pravilno izhaja tudi iz pravnih zaključkov sodišča druge stopnje.«
} 
priposestvuje $\mathrm{v}$ okviru nepravega priposestvovanja služnost $\mathrm{v}$ takšnem obsegu, kot jo je dejansko izvrševal dvajset let, lastnik služeče stvari pa takšnemu izvrševanju ni nasprotoval (drugi odstavek 217. člena SPZ). Obstoj pravnega naslova tukaj ni potreben. Pri nepravem priposestvovanju se tudi ne zahteva dobra vera priposestvovalca, vendar pa izvrševanje ne sme biti nepošteno (glej tretji odstavek 217. člena SPZ).

Dobra vera priposestvovalca pri pravem priposestvovanju terja obstoj veljavnega pravnega naslova za pridobitev služnosti. To bo največkrat služnostna pogodba, ki ne vsebuje zemljiškoknjižnega dovolila oziroma overjenega podpisa lastnika služeče nepremičnine na zemljiškoknjižnem dovolilu. Pri tem moramo biti pozorni, ali je pogodba po vsebini lahko pravni temelj za pridobitev služnosti, ali pa je zgolj obligacijsko pravni dogovor, ki ne more biti pravni temelj za nastanek stvarnopravnega razmerja. Če npr. lastnik dovoljuje neodplačno ali odplačno uporabo svoje nepremičnini tretji osebi, lahko gre za prekarij ali pa za najemno oziroma zakupno razmerje. Takšen zavezovalni pravni posel ni ustrezni pravni temelj za pridobitev služnosti. Tudi v primerih, ko je lastnik služeče stvari izjavil zgolj soglasje $\mathrm{z}$ uporabo njegove nepremičnine $\mathrm{v}$ določenem obsegu $\mathrm{v}$ korist tretje osebe, je treba zanesljivo ugotoviti, ali je izpolnjen pogoj obstoja ustreznega pravnega temelja za oblikovanje stvarnopravnega razmerja.

Zaradi predpostavk, ki so predpisane za nepravo priposestvovanje služnosti, pridobi upravičenec pravico do neodplačne uporabe tuje stvari. Prisilna pridobitev služnosti mora biti odplačna (glej tretji odstavek 89. člena SPZ glede nujne poti ter sedmi odstavek 110. člena $\mathrm{v}$ zv. s 105. in 106. členom ZUreP-1). Pravilo velja tudi za prisilno omejevanje lastninske pravice $\mathrm{v}$ zasebnem interesu (nujna pot). $V$ tej zvezi je treba presoditi, kakšen je način posega $\mathrm{v}$ lastninsko pravico na temelju priposestvovanja. $\mathrm{V}$ skladu $\mathrm{z}$ ustavnopravnimi jamstvi zasebne lastnine se lahko lastninska pravica odvzame ali omeji v javno korist le proti nadomestilu $\mathrm{v}$ naravi ali proti odškodnini pod pogoji, ki jih določa zakon (69. člen Ustave RS). Za prisilno ustanovitev služnosti v zasebnem interesu je predviden postopek za določitev nujne poti. Tudi v tem primeru je lastnik služeče nepremičnine upravičen do nadomestila. Pri prisilni omejitvi lastninske pravice $\mathrm{v}$ javnem interesu pa je pravica do nadomestila zagarantirana že na podlagi ustave. Ker se služnost $\mathrm{v}$ javno korist ustanavlja za dosego javne koristi in ker so poleg države in občin razlastitveni upravičenci tudi izvajalci javne službe in investitorji javne infrastrukture (glej 110. člen SPZ), je možnost pridobitve neodplačne služnosti na podlagi nepravega priposestvovanja v korist upravičencev iz 110. 
člena ZUreP-1, izključena. Dodatni argument je tudi ta, da SPZ (od 1.1.2003) več ne dopušča priposestvovanja nepravih stvarnih in osebnih služnosti. Ta argument zdrži zlasti v primeru, če razvrstimo služnosti v javno korist v podvrsto nepravih stvarnih služnosti. $\mathrm{V}$ kolikor jih zaradi njihove atipične pravne narave primerjamo s pravimi stvarnimi služnostmi pa dvajsetletno priposestvovanje nasprotuje (zaradi neodplačnosti) ustavnopravnim jamstvom zasebne lastnine. $\mathrm{V}$ tej zvezi bi si lahko kvečjemu zastavili vprašanje dopustnosti desetletnega priposestvovanja, ki ga je VS RS v eni izmed novejših odločb že dopustilo: „Priposestvovanje služnosti $v$ javno korist je mogoče ob pogoju (stroge presoje) dobre vere, še posebej, če temelji na pravnoposlovni podlagi. Pri tem ni pogoj, da je posel odplačen, če je le iz okoliščin primera jasno, da je takšno stanje plod pristne volje lastnika. «31 Stališče je bilo sprejeto v zvezi z dopuščeno revizijo VS, sklep II DoR 56/2014 z dne 9.4.2014.

6.3 Razvoj sodne prakse v zvezi s priposestvovanje služnosti v javno korist

Vrhovno sodišče RS je je sprva nekritično zavzelo stališče, da je dopustno (tudi nepravo) priposestvovanje (starih) služnosti v javno korist. ${ }^{32}$ Pri tem se je uprlo na pravna pravila ODZ ter pojasnilo, da »ODZ resda ni poznal pravnega términa služnosti $\mathrm{v}$ javno korist in $\mathrm{v}$ sedanji pravni teoriji uveljavljanih razvrstitev služnosti, vendar pa to ne pomeni, da tedanja zakonodaja tovrstnih primerov, kot je obravnavani, pravno ni urejala. ODZ je namreč v paragrafu 479 uredil t.i. nepravilne služnosti, za katere je značilno, da so po vsebini stvarne služnosti, ustanovljene zgolj $v$ korist določenega subjekta. Tudi zanje so veljala pravila o priposestvovanju, saj ODZ priposestvovanja služnosti ni omejil le na prave stvarne služnosti (priposestvovati je bilo mogoče stvarne, neprave stvarne in osebne služnosti)«.

\footnotetext{
31 VS, sodbo II Ips 210/2014, 8. 10. 2015.

32 VS, sodba in sklep II Ips 1022/2008, 29.11.2012: »ODZ resda ni poznal pravnega términa služnosti v javno korist in $\mathrm{v}$ sedanji pravni teoriji uveljavljanih razvrstitev služnosti, vendar pa to ne pomeni, da tedanja zakonodaja tovrstnih primerov, kot je obravnavani, pravno ni urejala. ODZ je namreč v paragrafu 479 uredil t.i. nepravilne služnosti, za katere je značilno, da so po vsebini stvarne služnosti, ustanovljene zgolj v korist določenega subjekta. Tudi zanje so veljala pravila o priposestvovanju, saj ODZ priposestvovanja služnosti ni omejil le na prave stvarne služnosti (priposestvovati je bilo mogoče stvarne, neprave stvarne in osebne služnosti).«
} 
$\mathrm{Na}$ dejstvo, da je bil glede navedenega stališča potreben vnovični premislek, kažejo dopuščene revizije. Tako je Vrhovno sodišče RS že hitro za tem dopustilo revizijo $^{33}$ glede pravnega vprašanja, »ali je $\mathbf{v}$ primeru, ko je priposestvovanje služnosti v javno korist začelo teči pred uveljavitvijo Zakona o urejanju prostora in Energetskega zakona, vendar se do uveljavitve teh zakonov ni izteklo, služnost $\mathrm{v}$ javno korist mogoče pridobiti le na podlagi pravnega posla in odločbe upravnega organa, ali jo je mogoče tudi priposestvovati? « Vrhovno sodišče RS je $\mathrm{v}$ tej zadevi tudi že odločilo. Dopustilo je pravo desetletno priposestvovanje služnosti $v$ javno korist, in sicer ob pogoju (stroge presoje) dobre vere, še posebej, če temelji na pravnoposlovni podlagi. Pri tem ni pogoj, da je posel odplačen, če je le iz okoliščin primera jasno, da je takšno stanje plod pristne volje lastnika. ${ }^{34}$

V začetku leta 2015 je bila znova dopuščena revizija ${ }^{35}$ glede vprašanja dopustnosti uporabe civilnopravnih pravil o priposestvovanju pri omejitvi lastninske pravice $\mathrm{v}$ javno korist ter glede vprašanja stvarne pristojnosti in izbire vrste postopka pri omejitvi lastninske pravice $v$ javno korist. ${ }^{36}$ Sodišče prve stopnje je $\mathrm{v}$ tej zadevi zavrnilo (primarni) tožbeni zahtevek, da so toženke dolžne tožnici izstaviti zemljiškoknjižno dovolilo, da se pri njih lastnih deležih na spornih nepremičninah vknjiži služnostna pravica postavitve, nadzora, upravljanja, vzdrževanja, popravila in rekonstrukcije elektroenergetskih objektov v korist tožnice v roku 15 dni, sicer bo listino nadomestila sodba. Ugodilo pa je (podrednemu) tožbenemu zahtevku, da ima tožnica na spornih nepremičninah služnostno pravico postavitve, nadzora, upravljanja, vzdrževanja, popravila in rekonstrukcije elektro-energetskih objektov. Toženke so v predlogu za dopustitev revizije navajale, da $v$ obravnavani zadevi sploh ne gre za odločanje o civilnopravnem razmerju, pač pa za upravno zadevo in da je glede izbire vrste postopka pri pridobivanju služnosti oziroma omejitvi lastninske pravice $\mathrm{v}$ javno korist praksa višjih sodišč neenotna (ob tem se sklicujejo na odločbo Upravnega sodišča I U 1280/2013). Prav tako je neenotna praksa višjih sodišč glede vprašanja dopustnosti priposestvovanja kot načina omejitve lastninske pravice $\mathrm{v}$

\footnotetext{
33 VS, sklep II DoR 56/2014, 9. 4. 2014.

34 VS, sodbo II Ips 210/2014, 8. 10. 2015.

35 VS, sklep II DoR 407/2014, 29.1.2015

${ }^{36} \mathrm{~V}$ tej zadevi je Višje sodišče v Ljubljani (VSL, sodba I Cp 2103/2014, 15.10.2014) zavzelo stališče (očitno pod vplivom odločbe VS, sodba in sklep II Ips 1022/2008, 29.11.2012), »da je priposestvovanje neprave stvarne služnosti mogoče. V okviru 8. odstavka 110. člena ZUreP-1 predpisana odškodnina, ki pripada lastniku v primeru ustanovitve služnosti (v javno korist), se nanaša zgolj na postopek za prisilno ustanovitev služnosti v javno korist. S takšno ureditvijo zakon ne posega v pravni položaj služnostnih pravic, pridobljenih pred njegovo uveljavitvijo, ne spreminja njihove vsebine in jih ne omejuje z novo denarno obveznostjo.« Vrhovno sodišče RS o reviziji še ni odločilo.
} 
javno korist (ob tem se sklicujejo na zadevo VSK Cp 432/2012). Trdijo, da po Stvarnopravnem zakoniku priposestvovanje neprave stvarne služnosti ni mogoče. Ne sprejemajo stališča Vrhovnega sodišča, zavzetega v zadevi II Ips 1022/2008, da je bilo po Občem državljanskem zakoniku mogoče priposestvovati neprave stvarne služnosti in da Zakona o urejanju prostora (ZUreP-1) ni mogoče uporabiti za razmerja, ki so nastala pred njegovo uveljavitvijo. Menijo, da navedena odločba Vrhovnega sodišča diskriminatorno obravnava pravdni stranki, da je v nasprotju z odločbo Ustavnega sodišča U-I224/00, opozarjajo pa tudi na Zakon o razlastitvi in prisilnem prenosu pravice uporabe iz leta 1972. Predlagajo dopustitev revizije tako glede vprašanja dopustnosti uporabe civilnopravnih pravil o priposestvovanju kot glede stvarne pristojnosti in izbire vrste postopka pri omejitvi lastninske pravice $\mathrm{v}$ javno korist. Zatrjujejo tudi kršitve iz 14., 22., 33. in 69. člena Ustave (ker so v neenakem položaju z drugimi lastniki nepremičnin, ki zaradi omejitve lastninske pravice na nepremičninah prejemajo denarno odškodnino samo zato, ker nosilec javne koristi v skladu z ZUreP-1 in Energetskim zakonom - EZ izbere upravni postopek).

Za razliko od citiranega stališča Vrhovnega sodišča RS, ${ }^{37}$ ki je ob uporabi pravnih pravil ODZ dopustilo celo nepravo dvajsetletno priposestvovanje služnosti v javno korist, pa je Višje sodišče $\mathbf{v}$ Kopru $^{38}$ zavzelo stališče, da priposestvovanje služnosti $\mathbf{v}$ javno korist ni dopustno. Pojasnilo je, »da vtoževana služnost predstavlja poseg države kot nosilca javnega interesa (oziroma oseb, ki jim država poveri izvajanje tega interesa) v zasebno lastnino, zato za pridobitev take služnosti ni mogoče uporabiti splošnih pravil o možnih načinih pridobitve služnosti. Za služnost $\mathrm{v}$ javnem interesu sta bila ves čas predvidena samo dva načina nastanka: pogodba ${ }^{39}$ in upravni postopek prisilne ustanovitve služnosti. Res je, da so v času izgradnje omrežja na ozemlju, na katerem je bil sporni daljnovod postavljen veljale določbe italijanskega Civilnega zakonika (kasneje pa še ODZ), vendar to ni pomembno, saj je bil Temeljni zakon o razlastitvi, ki je kot specialni predpis urejal (prisilni) prenos služnosti (in torej izključil uporabo ODZ), sprejet že leta 1947 in torej do sprejetja tega zakona služnost še ni mogla biti priposestvovana (tudi če bi ti predpisi priposestvovanje služnosti v javno korist dopuščali). V zvezi s priposestvovanjem služnosti po

\footnotetext{
${ }^{37}$ VS, sodba in sklep II Ips 1022/2008, 29.11.2012.

${ }_{38}$ VSK, sodba in sklep Cp 6/2014, 1. 4. 2014.

${ }^{39}$ Pogodbe, ki bi jo s takratnim lastnikom nepremičnine sklenila S., ki je daljnovod gradila, tožeča stranka ne zatrjuje.
} 
ODZ je treba še dodati, da je pogoj za priposestvovanje po paragrafu 1461 tudi pravična posest, torej posest, ki se opira na tak naslov, ki bi zadoščal za prevzem lastnine (oziroma v konkretnem primeru služnosti). Tožeča stranka se $\mathrm{v}$ zadevi ni sklicevala na noben tak naslov ${ }^{40}$ in tudi iz tega razloga niso izpolnjeni pogoji za priposestvovanje služnosti niti po ODZ. Ustavno sodišče RS je v več svojih odločbah ${ }^{41}$, ko je obravnavalo primere, ko so bili dejanski posegi, ki imajo značaj razlastitve, opravljeni v preteklosti, še vedno pa se nepremičnine uporabljajo $\mathrm{v}$ javno korist, poudarilo, da oseba, ki bi sicer lahko bila razlastitveni upravičenec, svoje opustitve zakonitega ravnanja, potrebnega za izpolnitev pogojev za dopustnost posega $\mathrm{v}$ lastninsko pravico na nepremičninah, ne more odpraviti na podlagi sklicevanja na določbe o originarni pridobitvi pravic po splošnih pravilih. Res so se te odločbe nanašale na ceste in železnice, torej dejanski odvzem lastninske pravice, vendar se položaj pri prisilni omejitvi lastninske pravice $\mathrm{v}$ bistvenem ne razlikuje. V obeh primerih gre za poseg države v zasebno lastnino, pri čemer trditve tožeče stranke, da je $\mathrm{v}$ zadnjem obdobju družba zasebnega prava, na te ugotovitve ne vplivajo, saj gre pri prenosu električne energije nesporno za izvajanje javne službe $\mathrm{v}$ javno korist (ki pa jo dejansko izvajajo subjekti, ki jim je država podelila to upravičenje). Povedano pomeni, da priposestvovanje kot način omejitve lastninske pravice $\mathrm{v}$ javno korist, ni dopustno, saj bi pomenilo poseg $\mathrm{v}$ z ustavo zavarovano pravico do zasebne lastnine.«

\subsection{Nedopustnost nepravega priposestvovanja služnosti v javno korist}

Po naši oceni je lahko pravni temelj za ustanovitev služnosti v javno korist le pravni posel in oblikovalna upravna odločba, izdana v postopku (nepopolne) razlastitve. Takšno stališče bi moralo veljati tudi za stare služnosti v javno korist. Pridobitev neodplačne služnosti $\mathrm{v}$ korist sistemskih operaterjev na temelju nepravega priposestvovanja nasprotuje osnovnemu konceptu (dopustnega) prisilnega posega $\mathrm{v}$ lastninsko pravico, kateri se lahko izvede le proti nadomestilu. Po sedaj veljavnem pravu (SPZ, ZUreP-1) je mogoče služnost $\mathrm{v}$ javno korist pridobiti le na podlagi pravnega posla ter odločbe upravnega organa. Pri pravno poslovnem načinu ustanovitve lahko lastnik pristane na neodplačnost pravnega

\footnotetext{
${ }^{40} \mathrm{~V}$ poštev bi prišlo sklicevanje na pogodbo o ustanovitvi služnosti, ki bi jo s takratnimi lastniki nepremičnin sklenil takratni izvajalec javne službe ali na kakšno upravno odločbo, s katero bi bila lastninska pravica omejena. ${ }^{41}$ U-I-224/00, s katero je razveljavilo 85. člen Zakona o javnih cestah in 137. člen Zakona o zemljiški knjigi, UI-316,04, s katero je razveljavilo 38. člen Zakona o železniškem prometu, ter številne odločbe, s katerimi so bile razveljavljene posamezne določbe občinskih odlokov o kategorizaciji javnih cest (U-I-222/10, U-I-208/10, U$\mathrm{I}-164 / 10$ in ostale).
} 
posla (to spada v vsebino zasebne avtonomije), kar mora biti vselej odraz njegove prave, resnične in svobodne volje. Stara dejanska stanja je sicer treba postaviti v tedanji čas, vendar ne na ta način, da proti volji lastnikov omejimo njihova upravičenja s klasičnimi inštituti civilnega prava (priposestvovanje služnosti), ki v konkretnih razmerjih nimajo kaj iskati. Sistemski operaterji distribucijskega omrežja so namreč razlastitveni upravičenci in ne klasični zasebno pravni subjekti. ${ }^{42}$ Nepravo priposestvovanje služnosti $v$ javno korist povzroči neodplačno uporabo nepremičnine, kar predstavlja nedopustno (nepopolno) razlastitev. Ustava RS ne dopušča razlastitve neposredno na podlagi zakona (še zlasti ne na podlagi pravnih pravil ODZ), ampak le po postopku, v katerem je s pravnimi sredstvi preizkušen obstoj javne koristi za razlastitev. Za dopustno razlastitev mora zmeraj obstaja nesporno ugotovljen javni interes, ki jemlje pravilno izpeljani razlastitvi lastnost protipravnosti. Razlastitev je nezakonita, ko gre za t.i. obrnjeni razlastitveni postopek. Gre za primer, ko je lastniku dejansko odvzeta posest (in s tem onemogočena uporaba nepremičnine), še preden je bilo pravnomočno odločeno o razlastitvi. V takšnih primerih je že nekdaj veljavni zakonu (drugi odstavek 55. člena Zakona o razlastitvi in prisilnem prenosu nepremičnin v družbeni lastnini - ZRPPN), ${ }^{43}$ kateremu je dala jasnejšo vsebino sodna praksa, kaznoval razlastitvenega upravičenca za obdobje nezakonitosti. $\mathrm{V}$ eni izmed odločb je Vrhovno sodišče RS navedlo: ${ }^{44}$ »Ne glede na to, da obstoj splošnega interesa oziroma javne koristi v trenutku, ko je predlagateljica prevzela posest nepremičnin, med udeležencema ni sporen, je nezakonito njeno ravnanje, $\mathrm{s}$ katerim je sporni nepremičnini najprej vzela $\mathrm{v}$ posest in na njiju zgradila infrastrukturo (za potrebe mejnega prehoda), dvanajst let kasneje pa je bila izdana odločba o razlastitvi in uveden postopek za določitev odškodnine. Pravilno je stališče sodišča, da se pri določitvi višine odškodnine za razlaščeno nepremičnino ne upošteva vrednost tega, kar je razlastitveni upravičenec zgradil na nepremičnini.« Sodišče je v obrazložitvi še zapisalo: »Posledice takega ravnanja v pravnem redu niso izrecno urejene. Ustavno sodišče RS je že zavzelo stališče, da Ustava RS ne dopušča razlastitve na podlagi zakona, ampak le po izvedbi postopka, v katerem je v postopku s pravnimi sredstvi preizkušen obstoj javne

\footnotetext{
${ }^{42}$ V tej zvezi glej tudi odločbo VS, sodba III Ips 59/2010, 7. 9. 2010.

${ }^{43}$ Zakon o razlastitvi in prisilnem prenosu nepremičnin v družbeni lastnini - ZRPPN (Uradni list SRS, št. 5/80, $30 / 87$ in 20/89). V preteklosti je razlastitev urejal ZRPPN. Za njim je področje razlastitve in odškodnine urejal Zakon o stavbnih zemljiščih - ZSZ (Uradni list RS, št. 44/97), ki je med drugim določil, da z dnem uveljavitve ZSZ (25.7.1997) prenehajo veljati določbe ZRPPN (56. člen ZSZ). V drugem odstavku 53. člena pa je ZSZ določil, da se «začeti postopki za določitev odškodnine po določbah Zakona o razlastitvi, končajo po dosedanjih predpisih«, tedaj po določbah ZRPPN (Sklep II Ips 386/99 z dne 25.5.2000). Danes ureja postopek razlastitve predvsem Zakon o urejanju prostora - ZUreP-1.

${ }^{44}$ VS, sklep II Ips 874/2009, 16. 9. 2010.
} 
koristi za razlastitev. Zavrnilo je tudi stališče, da bi bilo treba $\mathrm{v}$ primerih »dejanskih razlastitev«, se pravi razlastitev, v katerih je bila javna infrastruktura zgrajena, ne da bi bil prej izveden razlastitveni postopek, smiselno uporabiti 25. člen Zakona o temeljnih lastninskopravnih razmerjih - ZTLR, ki ureja (oz. je urejal) položaj graditelja in lastnika zemljišča $\mathrm{v}$ primeru graditeljeve nedobrovernosti. Tako razumevanje je po stališču Ustavnega sodišča RS, s katerim se Vrhovno sodišče strinja, v neskladju z Ustavo RS. Kadar obstajajo pogoji za odvzem ali omejitev lastninske pravice $\mathrm{v}$ javnem interesu, jih lahko razlastitveni upravičenci uveljavljajo pod pogoji, ki jih določa zakonodaja, ki ureja tovrstne posege, in ni dovoljena analogna uporaba pravil, ki urejajo civilnopravna razmerja.« 45

\subsection{Sporna določba 552. člena EZ-1}

V letu 2014 sprejeti Energetski zakon (EZ-1) je v 552. členu določil, da pridobi izvajalec gospodarske javne službe, na nepremičninah, na katerih se na dan uveljavitve tega zakona že nahaja infrastruktura (kot je opredeljena v 462. členu EZ-1), z uveljavitvijo tega zakona služnost $\mathrm{v}$ javno korist, če so za to izpolnjeni vsi pogoji za priposestvovanje služnosti skladno z zakonom in če je za pridobitev take služnosti izkazana javna korist skladno s 472. členom tega zakona. Izvajalec gospodarske javne službe lahko lastnikom nepremičnin posreduje ponudbo za sklenitev pogodbe o priznanju pridobitve služnosti (posadna listina). Če operater ali distributer $\mathrm{v} 30$ dneh po vročitvi ponudbe za sklenitev pogodbe o priznanju pridobitve služnosti take pogodbe ne uspe skleniti, lahko zoper lastnika nepremičnine vloži tožbo na ugotovitev obstoja služnosti v javno korist.

Zakonodajalec je s sporno določbo zajel tako pravo kot tudi nepravo priposestvovanje služnosti $\mathrm{v}$ javno korist (in to brez nadomestila). Do takšne rešitve je zakonodajalec najverjetneje prišel pod vplivom odločbe VS RS II Ips 1022/2008 z dne 29.11.2012, ki je ob uporabi pravnih pravil ODZ dopustilo nepravo dvajsetletno priposestvovanje služnosti v javno korist. Zapisali smo že,

\footnotetext{
45 Vrhovno sodišče RS je v citirani odločbi (VS, sklep II Ips 874/2009, 16. 9. 2010) še navedlo, da je takšno stališče skladno s stališči ESČP o vsebini jamstva zasebne lastnine po 1. členu Protokola k Evropski konvenciji o človekovih pravicah - EKČP. Sodišče izhaja iz razlikovanja med primeri nedopustne razlastitve (zasegi), ki zahtevajo polno odškodnino, in primeri, ko je razlastitev sicer dopustna in ji za njeno zakonitost manjka le izplačilo odškodnine. V prvem primeru je prizadeta oseba upravičena do odškodnine, ki v največji možni meri odpravlja posledice nedopustnega ravnanja in vzpostavlja situacijo, ki bi po vsej verjetnosti obstajala, če nedopustnega ravnanja ne bi bilo. V drugem primeru je ustrezna odškodnina v višini tržne vrednosti zemljišča $\mathrm{v}$ času odvzema posesti, valorizirana $\mathrm{z}$ namenom odprave učinkov inflacije v vmesnem obdobju in z obrestmi, predpisanimi za uporabo tujega denarja.
} 
da ustava ne dopušča razlastitve neposredno na podlagi zakona (niti na podlagi pravnih pravil OZD in tudi ne na podlagi 552. člena EZ-1), ampak le po izvedbi postopka, v katerem je v postopku s pravnimi sredstvi preizkušen obstoj javne koristi za razlastitev. Določba 552. člena ima dve bistveni «napaki«. Prva je ta, da ima neposredni razlastitveni učinek, kar nasprotuje ustavno pravnim jamstvom zasebne lastnine in drugič, ker razlašča lastnika nepremičnine (sicer na način utesnitve lastninske pravice s služnostjo $\mathbf{v}$ javno korist) brez nadomestila. $\mathrm{V}$ oči bode zlasti možnost vložitve ugotovitvene tožbe za primer, ko lastnik s posadno listino ne želi priznati izvajalcu gospodarske javne službe »izvirne pridobitve služnostne pravice«.

\subsection{Zaključek}

Zakonodajalec je poskušal (v 552. členu EZ-1) s klasičnimi zasebnopravnimi instituti urediti pridobitev služnosti v javno korist tudi proti volji lastnika. V takih primerih klasično civilno pravo ne more biti ustrezna materialnopravna podlaga za utesnitev lastninske pravice (in še celo brez nadomestila). Za te primere je predviden postopek nepopolne razlastitve. Sodna praksa Vrhovnega sodišča RS ne izključuje možnosti, da bi $\mathbf{v}$ določenih primerih lahko dopustili pravo priposestvovanje služnosti $\mathrm{v}$ javno korist, vendar le tedaj, ko je operater izvrševal služnost na podlagi veljavnega pravnega naslova (npr. pogodbe), torej v dobri veri, da takšno pravico ima, ter je lastniku plačal ustrezno nadomestilo za služnost (oziroma je lastnik privolil v neodplačno omejitev lastninske pravice), pri čemer pa služnost ni bila vknjižena $\mathbf{v}$ zemljiško knjigo. Takšna možnost lahko pride $\mathrm{v}$ poštev le za pravo desetletno priposestvovanje služnosti (prvi odstavek 217. člena SPZ). Vrhovno sodišče RS je v odločbi II Ips 210/2014 z dne 8. 10. 2015 dopustilo neodplačno pravo priposestvovanje: »Priposestvovanje služnosti $v$ javno korist je mogoče ob pogoju (stroge presoje) dobre vere, še posebej, če temelji na pravnoposlovni podlagi. Pri tem ni pogoj, da je posel odplačen, če je le iz okoliščin primera jasno, da je takšno stanje plod pristne volje lastnika.« ${ }^{46}$ Stališče je bilo sprejeto v zvezi z dopuščeno revizijo II DoR

\footnotetext{
${ }^{46}$ Vrhovno sodišče RS je pri tem pojasnilo, »da se v literaturi se poudarja, da mora biti razlastitveni akt odplačen. To nedvomno in brezpogojno velja, kadar je razlastitveni akt odločba državnega organa. Vprašanje pa je, ali je ta zahteva na mestu tudi tedaj, ko je razlastitveni akt pravni posel ali pa, nasprotno, $v$ tem primeru prevladajo civilnopravne lastnosti pravnega posla. Ena izmed njih je tudi pogodbena avtonomija. Tako kot namreč lastnika ni ustavnopravno dopustno prisiliti v neodplačno razlastitev, ga v skladu s pogodbeno avtonomijo (ta je sestavni del tako splošne svobode ravnanja iz 35. člena Ustave kot tudi ustavno zajamčene lastninske pravice in $\mathrm{s}$ tem
} 


\section{sklep 56/2014 z dne 9.4.2014. Sklepamo lahko, da Vrhovno sodišče RS le izjemoma dopušča možnost zgolj pravega priposestvovanja "starih"} služnosti $\mathbf{v}$ javno korist. ${ }^{47} \mathrm{~V}$ konkretni zadevi se priposestvovalna doba za pravo priposestvovanje služnosti do uveljavitve SPZ (1.1.2003) še ni iztekla. Ker SPZ več ne dopušča priposestvovanja nepravih stvarnih služnosti in osebnih služnosti, se stališče Vrhovnega sodišča RS lahko vsaj na prvi pogled izkaže za problematično. Treba pa je opozoriti, da je lahko argument, da SPZ več ne dopušča priposestvovanja nepravih stvarnih služnosti in osebnih služnosti nepravilen za presojo dopustnosti priposestvovanja služnosti $\mathrm{v}$ javno korist. Služnost $\mathrm{v}$ javno o korist je zaradi akcesorne vključenosti v podjem nosilca javne

tudi pravice, da z njo neodplačno razpolagaš iz 33. člena Ustave) tudi ni dopustno prisiliti v (nujno) odplačno pravnoposlovno razlastitev. Iz tega izhaja, da zgolj zato, ker je pravni posel de facto neodplačen, še ne pomeni, da je razlastitev neveljavna. Pogoj je, da je bila volja svobodna. Po presoji revizijskega sodišča je treba pogoj odplačnosti $\mathrm{v}$ povezavi s pogodbeno avtonomijo relativizirati. Kaj vse navedeno pomeni z vidika možnosti priposestvovanja služnosti $v$ javno korist? Najprej to, da bi nasprotovalo ustavnemu izhodišču iz 69. člena Ustave, če bi sprejeli tezo, da lahko razlastitveni upravičenec (ki je oseba javnega prava) preprosto okupira služečo nepremičnino in opravi dejanski razlaščujoč poseg, nato pa čaka, da se bo iztekla priposestvovalna doba in bo razlastitev (!) tudi de iure izvršena. Če bi dopustili takšno prakso, ta ne bi nasprotovala le 69. členu Ustave, marveč bi bila v diametralnem nasprotju tudi z načelom pravne države (2. člen Ustave). To velja (najmanj) od razglasitve ustave dalje, torej od 23. decembra 1991. Po drugi strani pa ni videti a priornih razlagalnih razlogov, zaradi katerih bi ustavna določba o razlastitvi (69. člen Ustave) ali specialne določbe o ustanovitvi služnosti $v$ javno korist (že navedene določbe ZUreP-1 in ZSZ/97) v celoti izključevale uporabo splošnih pravil civilnega prava. Kadar se položaj prilega civilnopravnemu abstraktnemu dejanskemu stanu, je mogoča tudi civilnopravna posledica. Do tega, da ni mogoča, lahko privede le argument teleološke redukcije. Po naravi in namenu (telosu) ureditve razlastitve je brez dvoma prav, da so civilnopravna pravila izključena za primere, ki bi predstavljali obid določb o razlastitvi. Tak primer je opisan pod prejšnjo točko in z drugimi besedami pomeni, da nedobroverno priposestvovanje (drugi odstavek 217. člena SPZ) ne pride v poštev. Položaj, ko oblastni, javnopravni subjekt samovoljno izvršuje služnost 20 let, se v bistvenem razlikuje od položaja, ko to počne civilnopravni subjekt. Čeprav se položaj navidez prekriva s civilnopravnim dejanskim stanom, ga je treba tako s teleološko redukcijo (zaradi teže 2. člena Ustave) kot z ustavnoskladno razlago (zaradi javnopravnih posebnosti, ki izhajajo iz 69. člena Ustave) iz te sfere izvzeti. Bistveno drugačna pa je primerjava položajev, ko na eni strani oblastni, javnopravni subjekt $\mathrm{v}$ dobri veri (in na podlagi pravnega posla) izvršuje služnost in ko to isto na drugi strani počne civilnopravni subjekt. Razlogov za teleološko redukcijo tu ni. Tu v ravnanju oblastnega subjekta več ne gre za ravnanje, ki bi predstavljalo obid instituta razlastitve. Bistvo tu-opazovanega ravnanja je v nezavednem razkoraku med dejanskim in pravnim. Ta razkorak ni $\mathrm{v}$ svojih bistvenih prvinah prav nič drugačen kot $\mathrm{v}$ primeru, ko je subjekt ravnanja oseba civilnega prava. V obeh primerih gre nato le še za to, da se v imenu pravne varnosti (kar je zopet argument iz 2. člena Ustave) dejansko stanje prilagodi pravnemu. V obeh primerih gre za v bistvenem enak poseg v lastninsko pravico nasprotne stranke. Priposestvovanje pač vselej predstavlja poseg $\mathrm{v}$ ustavno varovano lastninsko pravico, a ta poseg je ustavno dopusten in sicer zaradi varstva pravne varnosti in pravnega prometa. Iz navedenih razlogov je po presoji revizijskega sodišča priposestvovanje služnosti $v$ javno korist mogoče ob pogoju (stroge presoje) dobre vere, še posebej, če temelji na pravnoposlovni podlagi. Pri tem ni pogoj, da bi bil posel odplačen, če je le iz okoliščin primera jasno, da je takšno stanje plod pristne volje lastnika."

$47 \mathrm{~V}$ konkretni zadevi je tožena stranka leta 1995 na nepremičnini, ki je bila tedaj še v lasti pravne prednice tožnika, postavila transformatorsko postajo s priključnim daljnovodom. Tožnik je kot lastnik zahteval, naj toženka postavljeno infrastrukturo odstrani, toženka pa se je zoper to branila, da ima služnostno pravico v javno korist. Osrednje vprašanje po tožbi in nasprotni tožbi je bilo, ali je tožena stranka služnost (nepravo stvarno služnost v javno korist) priposestvovala ali ne. Sodišče prve stopnje je ugotovilo, da je tožena stranka na podlagi pisnega dovoljenja tožnikove pravne prednice na njeni nepremičnini zgradila sporno elektro infrastrukturo. Toženi stranki je bilo hkrati dovoljeno tudi, da ob vzdrževalnih delih hodi in vozi po nepremičnini. Dalje ugotovi, da je tožena stranka v dobri veri (na podlagi soglasja in na njegovi podlagi pridobljenega gradbenega dovoljenja) in brez slehernega nasprotovanja od 31.5.1995 do leta 2007 izvrševala služnost. Sklep sodišča prve stopnje je, da je tožena stranka priposestvovala služnostno pravico v javno korist, zato je ugodilo ugotovitvenemu zahtevku po nasprotni tožni, lastninske zahtevke po tožbi pa je zavrnilo. 
službe in s tem njene prenosljivosti (skupaj s prenosom podjema ter pravice upravljati $z$ infrastrukturo določene vrste) ter zaradi časovne neomejenosti, veliko bliže pravi pozitivni stvarni služnosti (ne glede na dejstvo, da je njen imetnik določena oseba), kot nepravi stvarni ali osebni služnosti. Iz tega razloga bi lahko zavzeli stališče, da SPZ, ki ukinja možnost priposestvovanja za omenjene vrste služnosti, ne predstavlja pravne ovire za priposestvovanje služnosti $v$ javno korist. Ne glede na navedeno pa menimo, da predstavlja glavno pravno oviro za uporabo zasebnopravnega instituta priposestvovanja javnopravna narava služnosti v javno korist. Lastninsko pravico na nepremičnini je mogoče omejiti v javnem interesu le proti nadomestilu pod pogoji, ki jih določa zakon (to je ZUreP-1, ki ureja omejitev lastninske pravice s služnostjo v javno korist v 110. členu). Edini »zasebnopravni« pravni temelj za tovrstno utesnitev oz. omejitev lastninske pravice je lahko pravni posel (ki je tudi procesna predpostavka za dopustnost razlastitvenega postopka). Ta je tudi po naši oceni lahko neodplačen, če je to odraz izrecne in svobodne volje lastnika nepremičnine, katere lastninska pravice se s tem omejuje. Tudi pred uveljavitvijo SPZ-ja služnostim v javno korist ne moremo odrekati javnopravne narave. Tudi $\mathrm{v}$ preteklosti te služnosti niso imele drugačnih pravnih značilnosti. Prav tako so tudi v preteklosti (pred ZUreP1) veljali predpisi o razlastitvi in prisilnih omejitvah lastninske pravice na nepremičninah. Prav zaradi navedenega bi bilo po naši oceni najbolj dosledno in notranje konsistentno stališče, da služnosti $\mathrm{v}$ javno korist ni mogoče priposestvovati niti na način nepravega priposestvovanja in tudi ne na način pravega priposestvovanja, kar je Vrhovno sodišče RS sicer dopustilo. Javnopravna narava služnosti v javno korist izključuje možnost uporabe tistih zasebnopravnih institutov (kot pravnih temeljev pridobitve pravice), ki proti volji lastnika omejujejo lastninsko pravico (z razlaščujočim učinkom). Tudi novejše odločbe (sicer nižjih sodišč) ne delijo zadnjega ${ }^{48}$ stališča Vrhovnega sodišča RS. ${ }^{49}$ Spet po drugi strani pa $\mathrm{v}$ novejši teoriji najdemo stališče, da je dopustno tako pravo kot tudi nepravo priposestvovanje služnosti v javno korist (Damjan, 2016: 76-79). Razprava o tej pravni problematiki očitno še ni zaključena, na kar kaže dopuščena revizija, katero je Vrhovno sodišče RS dopustilo glede

\footnotetext{
48 Zavzetega v odločbi VS, sodba II Ips 210/2014 z dne 8. 10. 2015.

${ }^{49}$ VSL, sodba in sklep II Cp 3022/2015, 27.01.2016: Pri zatrjevani ustanovitvi služnosti v javno korist gre za razlaščajoč poseg oziroma poseg občine kot nosilke javnega interesa (oziroma oseb, ki jim občina podeli izvajanje tega interesa) v zasebno lastnino, zato za pridobitev take služnosti ni mogoče uporabiti splošnih pravil o možnih načinih pridobitve služnosti. Za služnost $\mathrm{v}$ javnem interesu sta bila ves čas predvidena samo dva načina nastanka: pogodba in upravni postopek prisilne ustanovitve služnosti. Zakoni, ki so v obdobju veljave ODZ urejali nastanek služnosti v javno korist, so lex specialis v razmerju do določb ODZ glede nastanka služnosti (ODZ je sicer med drugim predvideval možnost pridobitve služnosti na podlagi zakona oziroma priposestvovanja) in so izključili njihovo uporabo.
} 
pravnega vprašanja, ali zakoni, ki so veljali v času veljavnosti Občega državljanskega zakonika, Zakona o temeljnih lastninskopravnih razmerjih in Stvarnopravnega zakonika in so urejali razlastitev, izključujejo uporabo Občega državljanskega zakonika, Zakona o temeljnih lasninskopravnih razmerjih in Stvarnopravnega zakonika, ki se nanašajo na priposestvovanje služnosti $\mathbf{v}$ javno korist, oziroma ali je za pridobitev služnosti $\mathrm{v}$ javno korist mogoče uporabiti splošna pravila o načinih pridobitve služnosti oziroma ali je dopustna uporaba civilnopravnih pravil o priposestvovanju pri omejitvi lastninske pravice $\mathrm{v}$ javno korist. ${ }^{50}$

Vrhovno sodišče RS je tudi v letu 2018 ponovno izreklo, ${ }^{51}$ da ne pritrjuje stališču, da ustavna določba o razlastitvi ali specialne določbe o ustanovitvi služnosti v javno korist $\mathrm{v}$ celoti izključujejo uporabo splošnih pravil civilnega prava o priposestvovanju. $\mathrm{V}$ primerih, ko se položaj prilega (tudi) civilnopravnemu abstraktnemu dejanskemu stanju, je namreč mogoča tudi civilnopravna posledica. Izjema so primeri, ki bi predstavljali obid določb o razlastitvi. Izjemno naravo služnosti $\mathrm{v}$ javno korist določa njena javnopravna lastnost, tj. da gre pri njej za razlaščajoč poseg (ne sicer za odvzem, ampak za omejitev lastninske pravice), ki mora biti zato $\mathrm{v}$ skladu z ustavnopravnimi varovali. Glede teh situacij je treba uporabo splošnega pravila o priposestvovanju teleološko (z ustavnoskladno razlago) utesniti. Položaj, ko oblastveni, javnopravni subjekt samovoljno (brez pravnega naslova) izvršuje služnost dvajset let, se namreč bistveno razlikuje od položaja, ko to počne civilnopravni subjekt. $\mathrm{V}$ duhu take razlage ni mogoče dopustiti pridobitve služnosti $\mathrm{v}$ javno korist $\mathrm{s}$ priposestvovanjem, ki ne bi bilo dobroverno (še posebej, če ne bi temeljilo na pravnoposlovni podlagi).

In končno je videti jasnejše ustavnopravne premike v odločbi Up-849/14$49 \mathrm{z}$ dne 27.09.2018, ki naposled pravilno pojasnjuje sledeče: »Pritožnice izpodbijajo sodne odločbe, izdane $\mathrm{v}$ dveh pravdah med istimi strankami. V prvi pravdi (št. P 117/2011) sta sodišči odločali o zahtevku pritožnic za plačilo odškodnine v višini 31.557,45 EUR s pripadki, vloženem zoper toženo stranko, pravno naslednico Združenega podjetja za distribucijo električne energije Slovenije (v nadaljevanju nasprotno stranko), ki je po ugotovitvah sodišč na nepremičninah pritožnic oziroma njihovih pravnih prednikov zgradilo daljnovod in dva srednjenapetostna kablovoda, ne da bi izpeljalo razlastitveni postopek

${ }^{50}$ VS, sklep II DoR 85/2016, 23.6.2016.

51 VS, sodba II Ips 282/2016, 06.09.2018. 
oziroma postopek za omejitev lastninske pravice. Tožbeni zahtevek pritožnic je bil pravnomočno zavrnjen na podlagi ocene o zastaranju odškodninske terjatve. Vrhovno sodišče je zavrnilo predlog pritožnic za dopustitev revizije. V drugi pravdi (št. P 128/2013) je bilo ugodeno podrejenemu tožbenemu zahtevku nasprotne stranke za ugotovitev, da ima na nepremičninah $\mathrm{v}$ solasti pritožnic služnostno pravico postavitve, nadzora, upravljanja, vzdrževanja, popravila in rekonstrukcije elektroenergetskih objektov, tj. električnih vodov, zaradi katerih so pritožnice $\mathrm{v}$ prvi pravdi zahtevale odškodnino. Nosilno stališče izpodbijanega dela pravnomočne sodbe je, da je nasprotna stranka priposestvovala nepravo stvarno služnost na podlagi splošnih pravil stvarnega prava.

Z izpodbijano pravnomočno sodbo je bilo ugodeno (podrejenemu) tožbenemu zahtevku nasprotne stranke, da ima na nepremičninah z ID znakom 1455-423/50 in z ID znakom 1455-423/8-0, ki so v solasti pritožnic, služnostno pravico postavitve, nadzora, upravljanja, vzdrževanja, popravila in rekonstrukcije elektroenergetskih objektov - to je visokonapetostnega daljnovoda in dveh srednjenapetostnih kablovodov (kot podrobneje izhaja iz izreka sodbe sodišča prve stopnje). Odločitev sodišč temelji na stališču, da je nasprotna stranka priposestvovala nepravo stvarno služnost na podlagi splošnih pravil stvarnega prava, in to neodplačno, saj naj stvarnopravna pravila za ta pridobitni način ne bi predvidevala odmene. Iz sodbe sodišča prve stopnje izhaja, da je nasprotna stranka služnostno pravico začela izvrševati leta 1975, ko je bil zgrajen daljnovod, in da se je priposestvovalna doba iztekla $\mathrm{v}$ letu 1995. To pomeni, da se je priposestvovalna doba iztekla $\mathrm{v}$ času po začetku veljavnosti Ustave (to je po 23. 12. 1991). Po stališčih Višjega sodišča je nasprotna stranka s tem na podlagi zakona izvirno pridobila »novo« pravico, pridobljene pravice pa Ustava varuje, zato »ni mogoče govoriti o kršitvi pravic toženk« (tj. pritožnic). Višje sodišče je poudarilo, da se lastniki nepremičnine več kot 35 let niso uprli in so, kot je sklenilo, »torej molče pristajali na izvrševanje služnosti«.

Sodišči sta odločitev oprli na stvarnopravna pravila o priposestvovanju in poudarili, da na ta način pridobljeno (služnostno) pravico nasprotne stranke varuje Ustava. Ustavnemu sodišču se zaradi razlogov, razvidnih iz nadaljevanja obrazložitve, ni treba opredeljevati, ali je položaj nasprotne stranke, opredeljen v izpodbijanih sodbah, varovan v okviru pravice iz 33. člena Ustave. Vendar pa je treba upoštevati, da odločitev sodišča o priposestvovani služnosti neposredno vpliva na položaj lastnika nepremičnine. Po mnenju pritožnic bi sodišči morali upoštevati, da je njihov lastninskopravni položaj zavarovan po 33. členu Ustave, 
poleg tega pa jim Ustava zagotavlja še varstvo po 69. členu Ustave, ker naj bi dejanski stan obravnavane zadeve ustrezal primeru dejanske razlastitve.

Ustavno sodišče že v odločbi št. U-I-224/00 sprejelo stališče, da izjave lastnikov zemljišč, da dopuščajo poseg $\mathrm{v}$ svoje zemljišče, dane $\mathrm{v}$ postopku pridobitve lokacijskega dovoljenja za gradnjo ali rekonstrukcijo (tedaj ceste), ne ustrezajo pojmu pravnega posla za pridobitev stvarnopravne pravice.

Nosilno stališče sodišč tako povsem spregleda pomen obrambne funkcije pravice do zasebne lastnine. Zato ne daje nobene ustavnopravne teže jamstvom iz 69. člena Ustave. Glede na navedeno, nosilno stališče izpodbijanih sodb ni sprejemljivo $z$ vidika pravice do zasebne lastnine iz 33. člena $\mathbf{v}$ zvezi z 69. členom Ustave. Ustavno sodišče je zato izpodbijani sodbi razveljavilo in zadevo vrnilo Okrajnemu sodišču v Novem mestu v novo odločanje (1. točka izreka). Ker je Ustavno sodišče izpodbijani sodbi razveljavilo že zaradi kršitve pravice iz 33. člena Ustave, se ni spuščalo v presojo drugih zatrjevanih kršitev človekovih pravic.« 


\begin{tabular}{|c|c|}
\hline & \\
\hline 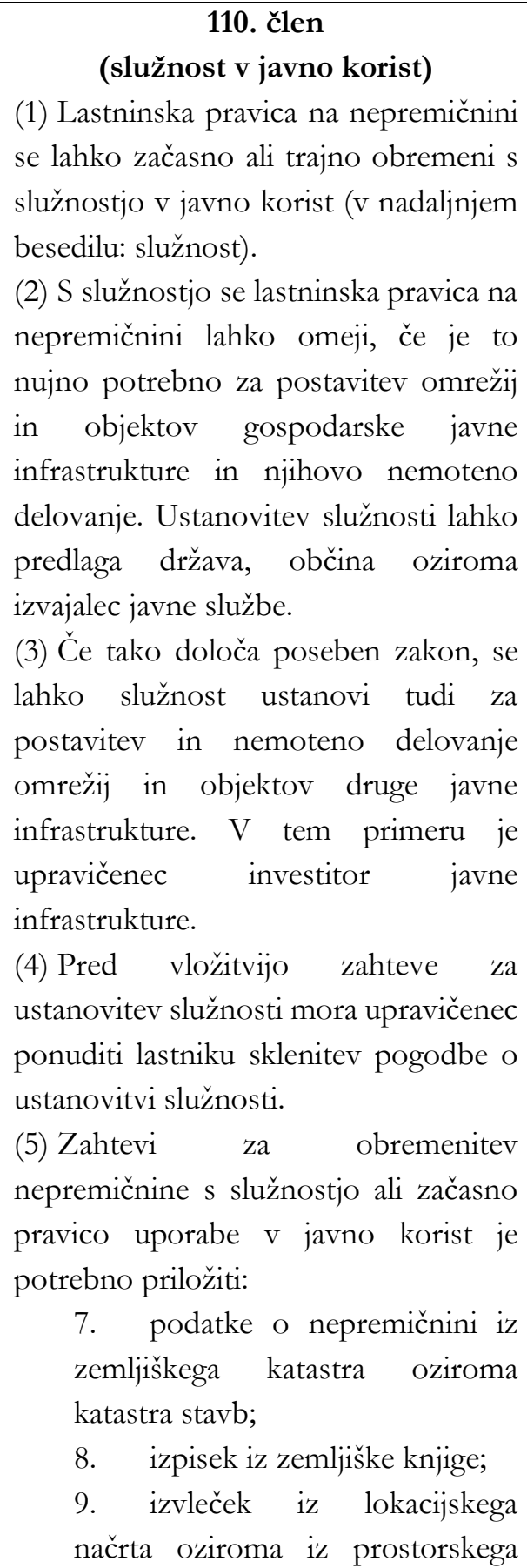 & $\begin{array}{l}\text { služnost). } \\
\text { (2) S služnostjo se lastninska pravica } \\
\text { na nepremičnini lahko omeji, če je } \\
\text { to nujno potrebno za gradnjo } \\
\text { omrežij in objektov gospodarske } \\
\text { javne infrastrukture ali njihovo } \\
\text { nemoteno delovanje. Ustanovitev } \\
\text { služnosti lahko predlaga država, } \\
\text { občina oziroma izvajalec javne } \\
\text { službe. } \\
\text { (3) Če tako določa poseben zakon, } \\
\text { se lahko služnost ustanovi tudi za } \\
\text { gradnjo ali nemoteno delovanje } \\
\text { omrežij in objektov druge javne } \\
\text { infrastrukture. V tem primeru je } \\
\text { upravičenec investitor javne } \\
\text { infrastrukture. } \\
\text { (4) Pred vložitvijo zahteve za } \\
\text { ustanovitev služnosti mora } \\
\text { upravičenec ponuditi lastniku } \\
\text { sklenitev pogodbe o ustanovitvi } \\
\text { služnosti. } \\
\text { (5) Zahtevi za obremenitev } \\
\text { nepremičnine s služnostjo v javno } \\
\text { korist je treba priložiti: } \\
\text { - seznam nepremičnin, predlaganih } \\
\text { za obremenitev, z njihovimi podatki } \\
\text { iz zemljiškega katastra oziroma } \\
\text { katastra stavb in zemljiške knjige; }\end{array}$ \\
\hline
\end{tabular}


reda občine, če se služnost - izvleček iz DPN, uredbe o ustanavlja na njegovi podlagi;

10. obrazložitev javne koristi;

11. opredelitev trajanja in načina služnosti oziroma začasne pravice uporabe;

12. ponudbo za sklenitev pogodbe o služnosti ali začasni uporabi iz četrtega odstavka tega člena.

(6) O zahtevi za ustanovitev služnosti odloči upravni organ $\mathrm{z}$ odločbo. O pritožbi zoper to odločbo odloča ministrstvo za prostor, razen če je $z$ drugim zakonom določeno drugače.

(7) Glede ugotavljanja dopustnosti ustanovitve služnosti po tem členu in glede drugih vprašanj, ki niso posebej urejena, se smiselno uporabljajo določbe tega zakona o razlastitvi.

(8) V primeru ustanovitve služnosti lastniku pripada odškodnina, ki obsega zmanjšano vrednost nepremičnine ali dejansko škodo in izgubljeni dobiček. $\mathrm{O}$ tem odloča sodišče na predlog prizadetega lastnika.

(9) Odločba o ustanovitvi služnosti v javno korist se lahko izvrši, ko postane pravnomočna, razen če upravni organ ugotovi, da gre za nujni primer iz 104. člena tega zakona. varovanem območju, OPN ali OPPN, če se služnost ustanavlja na njegovi podlagi;

- opredelitev trajanja in načina služnosti in

- ponudbo za sklenitev pogodbe o služnosti ali začasni uporabi iz prejšnjega odstavka.

(6) Ne glede na določbe predpisov, ki urejajo stvarnopravna razmerja, se lahko uvede postopek omejitve lastninske pravice tudi zoper posameznega solastnika ali skupnega lastnika nepremičnine, če so zanj izkazani pogoji za uvedbo postopka.

(7) Odločba o ustanovitvi služnosti v javno korist se lahko izvrši, ko postane pravnomočna, razen če upravni organ ugotovi, da gre za nujni postopek iz 205. člena tega zakona.

(8) V primeru ustanovitve služnosti lastniku nepremičnine pripada odškodnina, ki obsega zmanjšano vrednost nepremičnine ali dejansko škodo in izgubljeni dobiček. O tem odloča sodišče na predlog lastnika nepremičnine.

(9) Če ni $\mathrm{v}$ tem členu določeno drugače, se glede drugih vprašanj, ki niso posebej urejena, uporabljajo določbe tega zakona o razlastitvi. 


\section{Sklep}

Predstavljeni interesni konflikti med javnim in zasebnim so najbrž posledica tranzicije $\mathrm{v}$ nek drug pravni sistem, $\mathrm{s}$ (pregovorno) posebej naglašenimi ustavnopravnimi garancijami do zasebne lastnine. Sodna praksa Vrhovnega sodišča RS po oceni Ustavnega sodišča RS z svojimi nosilnimi stališči (na primeru služnosti v javno korist) povsem spregleda pomen obrambne funkcije pravice do zasebne lastnine. Zato ne daje nobene ustavnopravne teže jamstvom iz 69. člena Ustave. Prav zaradi tega stališče o dopustnosti (brezplačnega) priposestvovanja služnosti $\mathrm{v}$ javno korist ni sprejemljivo z vidika pravice do zasebne lastnine iz 33 . člena v zvezi z 69. členom Ustave RS.

\section{Literatura}

Berden, A., Juhart, M., Tratnik, M., Rijavec, V., Keresteš, T., Vlahek, A. \& Vrenčur, R. (2004) Stvarnopravni zakonik s komentarjem (Ljubljana: GV Založba).

Damjan, M. (2016) Služnost v javno korist, Pravosodni bilten, 37(1), str. 69-80.

Demšar, D. (2011) Geodetska uprava s parcelacijami razlaščala zasebna zemljišča, Pravna praksa, 30(45), str. 12-14.

Ekart, A. (2006) Črna gradnja in načelo zaupanja v zemljiško knjigo, Pravna praksa, 25(17), str. 20.

Juhart, M. \& Tratnik, M. \& Vrenčur, R. (2007) Stvarno pravo (Ljubljana: GV Založba).

Krisper-Kramberger, M. (1998) Javno dobro v novi pravni ureditvi, Pravna praksa, 17(4), str. I-VIII.

Plavšak, N. (2012) Služnosti v javno korist, V: 4. dnevi stvarnega in zemljiškoknjižnega prava (Ljubljana: GV Založba).

Plavšak, N. \& Vrenčur, R. (2016) Prenosljivost in časovna omejenost nepravih stvarnih služnosti in služnosti v javno korist, Podjetje in delo, 42(8), str. 1407-1430.

Plavšak, N. \& Vrenčur, R. (2018) Uporaba 93. člena Gradbenega zakona v pravnem prometu z nepremičninami, Odvetnik, 20(4), str. 22-27. 


\title{
Mediji o podjetništvu
}

\author{
Jan StajnKo, Šime IVANJKo IN MiHa ŠEPEC
}

Povzetek V prispevku avtorji obravnavajo razmerje med mediji in podjetniki, pri čemer ugotovijo, da se že majhna napaka pri vsakodnevnem poslovanju lahko $\mathrm{v}$ medijih prikaže na različne načine in ima lahko za posledico ne samo materialno škodo, temveč se z neznosno lahkotnostjo diskreditira tudi dostojanstvo človeka, ki je bodisi $\mathrm{v}$ vlogi člana poslovodstva ali lastnika. Poseben poudarek zaradi tega avtorji posvečajo medijskem sojenju in družbenim omrežjem ter medijskem poročanju $\mathrm{v}$ kazenskih postopkih. Rdeča nit prispevka je razprava, ki je potekala v okviru okrogle miza na temo medijskega poročanja o podjetništvu $\mathrm{v}$ Portorožu, na mednarodnem srečanju Gospodarski subjekti na trgu in evropske dimenzije 2018, ki jo avtorji v prispevku dopolnijo in nadgradijo z nekaterimi novimi izhodišči in idejami.

Ključne besede: • mediji $\bullet$ podjetništvo $・$ medijska sodba • družbena omrežja $\bullet$ kazensko pravo $\bullet$

\footnotetext{
NASLOVI AVTORJev: Jan Stajnko, Univerza v Mariboru, Pravna fakulteta, Maribor, Slovenija, epošta: jan.stajnko@um.si. Šime Ivanjko, Univerza v Mariboru, Pravna fakulteta, Maribor, Slovenija, e-pošta: sime.ivanjko@um.si. Miha Šepec, Univerza v Mariboru, Pravna fakulteta, Maribor, Slovenija, e-pošta: miha.sepec@um.si.
} 


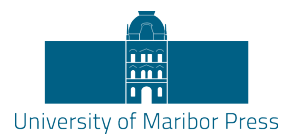

\title{
Media on entrepreneurship
}

\author{
Jan StajnKo, Šime IVANJKo \& MiHa ŠEPEC
}

\begin{abstract}
In this contribution authors discuss the relationship between media and entrepreneurs, whereby they argue that even a minor mistake by the entrepreneur can be presented to public in various context by the media. An exposure to the public can have significant monetary consequences for the business if presented in an absurdly negative context. It can, however, also gravely discredit the entrepreneur's dignity. This is why in this contribution authors tackled the phenomenon of trial by media and social media as well as media reports in criminal legal proceedings. The fundament upon which this contribution expands is the discussion emerging after a round table on media and entrepreneurs, which took place in Portorož, at the Corporate Entities in the Market and European Dimensions conference 2018.
\end{abstract}

Keywords: $\bullet$ media $\cdot$ entrepreneurship $\cdot$ trial by media $\cdot$ social media $\bullet$ criminal law $\bullet$

CORRESPONDENCE ADDRESS: Jan Stajnko, University of Maribor, Faculty of Law, Maribor, Slovenia, e-mail: jan.stajnko@um.si. Šime Ivanjko, University of Maribor, Faculty of Law, Maribor, Slovenia, e-mail: sime.ivanjko@um.si. Miha Šepec, University of Maribor, Faculty of Law, Maribor, Slovenia, e-mail: miha.sepec@um.si. 


\section{$1 \quad$ Uvod}

V okviru mednarodnega srečanja pravnikov v gospodarstvu Gospodarski subjekti na trgu in evropske dimenzije, ki ga je organizirala Pravna fakulteta Univerze v Mariboru, je 17. 5. 2018 v Portorožu potekala okrogla miza na temo medijskega poročanja o podjetništvu ob sodelovanju Društva za medijsko kulturo v Mariboru. ${ }^{1}$

Okroglo mizo sta vodila dr. Š. Ivanjko in dr. M. Šepec iz Pravne fakultete. Ob spodbudnih besedah voditeljev okrogle mize se je razvila vsesplošna razprava med številnimi udeleženci, nanašala pa se je predvsem na sporne in škodljive oblike medijskega sojenja na področju podjetništva. ${ }^{2}$ Posebej so bile zanimive razprave sodnikov, državnega tožilstva, pravnikov iz gospodarstva in študentov.

Temeljna ugotovitev je bila, da pravo ne nudi prizadetim dovolj varstva pred medijskim poročanjem, ki pogosto predstavlja medijsko sodbo o podjetniku ali celo podjetništvu ter da je treba $z$ aktivnim opozarjanjem na neprofesionalno poročanje doseči višjo raven medijske kulture pri bralcih oziroma gledalcih. Ob tem pa je treba upoštevati, da mediji nastopajo na trgu enako kot drugi udeleženci in so pogosto zaradi različnih ekonomskih interesov v konkurenčnem položaju. Organizator je na to srečanje povabil tudi predstavnike medijev, vendar so zavrnili udeležbo.

V tem prispevku, ki so ga avtorji sestavili ob koncu decembra 2018, so podane izhodiščne ideje, ki so se razvile tekom razprave na omenjeni okrogli mizi, te pa so obogatene $z$ razmišljanji avtorjev o širši problematiki medijev in podjetništva ter medijskih sodbah sploh.

\footnotetext{
${ }^{1}$ Društvo za medijsko kulturo v Mariboru je bilo ustanovljeno na pobudo podpisanega prof. dr. Šime Ivanjka 14.9. 1998, ki je opravljal funkcijo njegovega predsednika do septembra 2018, ko je predsedovanje prevzel Jan Stajnko, mag. prava, asistent na Pravni fakulteti Univerze v Mariboru in doktorski študent na Pravni fakulteti Univerze v Ljubljani, ki sodeluje pri izvedbi predmeta medijsko pravo na Fakulteti za elektrotehniko računalništvo in informatiko Univerze $\mathrm{v}$ Mariboru.

2 Okrogli mizi je prisostvovalo približno 180 udeležencev - pretežno pravnikov, ki se ukvarjajo s problematiko podjetništva. Tudi zaradi tega je uvodnim prispevkov sledila burna javna razprava o vlogi medijev v družbe ter njihovega odnosa do podjetništva.
} 


\section{$2 \quad$ Podjetništvo in mediji}

Gospodarski subjekt, ne glede na statusno obliko (kapitalska ali osebna družba, podjetnik posameznik oziroma zasebnik, zavod, zadruga in druge statusne oblike - v nadaljevanju podjetje) je del širšega družbenega okolja in je kot takšen vedno $\mathrm{v}$ različnih oblikah komunikacije $\mathrm{z}$ družbeno javnostjo. Na področju omenjene komunikacije so imajo pomembno vlogo mediji. Ti imajo v družbi različne pojavne oblike ( tiskani mediji, radio, televizija, družbena omrežja in podobno). Mediji imajo raznovrstne funkcije tako $\mathrm{v}$ družbi kot $\mathrm{v}$ podjetništvu ter $\mathrm{v}$ razmerju med podjetništvom in širšo družbo; širši javnosti posredujejo informacije o podjetjih in podjetjem posreduje potrebne informacije za njihovo poslovanje, med seboj tudi poslovno sodelujejo (spomnimo na ekonomske reklame, ki jih mediji vsakodnevno proti plačilu $\mathrm{v}$ različnih oblikah posredujejo javnosti). $\mathrm{Ob}$ tem pa so mediji tudi samo praviloma organizirani kot podjetja, zavodi in drugo.

Najpomembnejša funkcija medijev je ustvarjanje javnega mnenja o podjetništvu nasploh in o posameznih podjetjih, pri čemer je lahko ustvarjanje tega mnenja tako korektno in objektivno kot tudi pristransko, škodljivo in pogosto za podjetje ali podjetnika uničujoče. Mediji lahko svoje delo opravljajo v okviru svojih dejavnosti, pri čemer so praviloma plačani s prodajo svojih informacij (na primer časopisa) na prostem trgu ali pa $\mathrm{z}$ neposrednim financiranjem $\mathrm{s}$ strani podjetij. Slednjim je sicer v korist, da se javnosti posreduje informacija o podjetju, njihovih storitvah in blagu. Pri tem je pogosto vprašanje, ali je javnosti posredovana informacija bolj ali manj naklonjena podjetju (pozitivno ali negativno poročanje) posredno ali neposredno odvisna od financiranja medijev. Mediji lahko javnosti posredujejo tudi informacije, ki so posledica financiranja s strani konkurenčnih podjetij, in sicer z namenom, da se tujemu podjetju škoduje in morda tudi v celoti odstrani iz prostega trga.

$\mathrm{Z}$ mediji pogosto sodelujejo tudi organi pregona. Bodisi gre za to, da so mediji le posredovalci informacij o delovanju omenjenih organov, bodisi za to, da organi pregona in mediji sodelujejo na odkrivanju morebitnih nepravilnosti $\mathrm{v}$ poslovanju podjetnikov. Danes je posebej prisotno poročanje medijev o delu pravosodnih organov, pri čemer je lahko to poročanje korektno $\mathrm{v}$ smislu objektivnega poročanja ali pa gre za »navijaško poročanje«, ki ima za namen v javnosti ostvariti mnenje o »nesporni» odgovornosti za domnevne nepravilnosti. V takšnih primerih govorimo o medijskih obsodbah, ki lahko imajo za podjetnika 
celo bolj usodne posledice kot sodbe pravosodnih organov. ${ }^{3}$ Res je sicer, da mediji opravljajo določeno obliko nadzora na poslovanjem podjetjih in od tod opredeljuje kot »pse čuvaje«. ${ }^{4} \mathrm{~V}$ medijih naj bi delovali ljudje (novinarji) visoke profesionalnosti in izobraženosti, ter moralno pokončne osebnosti. Posebej je pri njihovem delu pomembno to, da se sklicujejo na svojo pravico do sirokega prostora varovanja medijske svobode in izražanja, ki je ustavno varovana svobošcina, in sicer kot splošno načelo, veljavno za vsakega, ki pa ima ob tem poseben pomen za delavce v svetu medijev (novinarje). ${ }^{5} \mathrm{~V}$ tem smislu ima vsakdo pravico dobiti informacijo javnega značaja, za katero ima v zakonu utemeljen pravni interes, razen v primerih, ki jih določa zakon. ${ }^{6}$ Zagotovljena je tudi pravica do popravka objavljenega obvestila, s katerim sta prizadeta pravica ali interes posameznika, organizacije ali organa, in prav tako je zagotovljena pravica do odgovora na objavljeno informacijo. ${ }^{7}$

\section{Nekateri pravni vidiki delovanja medijev na področju podjetništva}

Področje medijev je predmet številnih zakonskih in podzakonskih predpisov, ki so po naravi stvari vedno $\mathrm{v}$ interesnem fokusu oblastne interesne ideologije. Najpomembnejši predpis je Zakon o medijih $(Z M e d)^{8}$ ki določa pravice, obveznosti in odgovornosti pravnih in fizičnih oseb ter javni interes Republike Slovenije na področju medijev. Primarno gre za organizacijski predpis, ki pa vsebuje tudi nekatera bistvena načela za delovanje medijev. Pri tem je za potrebe

\footnotetext{
3 "Izrekanje sodb v poročanju o kaznivih dejanjih ali o dejanjih, ki lahko imajo znake kaznivega dejanja, imenujemo medijsko sojenje (trial by newspaper - Medienjustiz). Takšno sojenje je s pravnega vidika protipravno, z etičnega vidika pa neetično in $\mathrm{v}$ nasprotju z etičnimi kodeksi. Medijsko sojenje negira vrsto temeljnih pravnih in moralnih načel ter najbolj ogroža moralno varstvo posameznika. Z medijskim sojenjem novinar samovoljno oblikuje obsodbo, čeprav zanjo ni niti pristojen niti je ni sposoben oblikovati." (Ivanjko, 1997: 1185).

${ }^{4} \mathrm{Ob}$ tem v slovenski teoriji Ceferin upravičeno izpostavlja, da izraz "pes čuvaj" ni najbolj posrečen prevod izraza "public watchdog", ki se je uveljavil v tuji pravni literaturi. Vsebinsko pravilnejši izraz, ki nima vrednostno negativnega priokusa, je "varuh javnega interesa". Vendar se slednja terminologija v Sloveniji še ni uveljavila, zaradi tega $\mathrm{v}$ prispevku ne glede na navedeno v izogib ustvarjanju zmede še vedno uporabljamo izraz "pes čuvaj" (Čeferin, 2013: 30).

${ }_{5}^{5}$ Posebej je za medije pomembno načelo svobode izražanja misli, govora in javnega nastopanja, tiska in drugih oblik javnega obveščanja in izražanja. Vsakdo lahko svobodno zbira, sprejema in širi vesti in mnenja (39.člen Ustave RS). V zvezi s tem glej na primer (Teršek, 2007: 11-14).

${ }^{6}$ Glej 2. odstavek 39. člena Ustave RS. V našem prostoru imamo nadalje ta privilegij, da je Zakon o dostopu do informacij javnega značaja (ZDIJZ) (Uradni list RS, št. 51/06 - uradno prečiščeno besedilo, 117/06 ZDavP-2, 23/14, 50/14, 19/15 - odl. US, 102/15 in 7/18) eden tistih zakonov, ki mu je slovenska pravna teorija posvetila toliko pozornosti, da je izšel skupaj s komentarjem, ki olajša razumevanje zakonskega besedila. Glej (Pirc Musar \& Kraigher Mišič, 2017) v celoti.

${ }^{7}$ Glej 40. člen Ustave RS.

${ }^{8}$ Zakon o medijih (Uradni list RS, št. 110/06 - uradno prečiščeno besedilo, 36/08 - ZPOmK-1, 77/10 ZSFCJA, 90/10 - odl. US, 87/11 - ZAvMS, 47/12, 47/15 - ZZSDT, 22/16 in 39/16)
} 
tega zapisa treba posebej opozoriti na zakonske temelje za opravljanje dejavnosti medijev, določene v 6. členu ZMed. ${ }^{9}$

Za posamezne medije so sprejeti se posebni predpisi, kot na primer Zakon o Radioteleviziji Slovenija (ZRTVS-1). ${ }^{10}$ Posebno naravi in težo imajo tudi raznovrstni podzakonski predpisi ter avtonomni predpisi, med katerimi je gotovo treba izpostaviti Kodeks novinarjev Slovenije. ${ }^{11}$ Ta vsebuje etične standarde, usmeritve in zavezo za delo novinarjev in drugih ustvarjalcev vsebin, ki so objavljene v slovenskih medijih, ne glede na oblike njihovega razširjanja. ${ }^{12}$

Posebej so novinarji varovani tudi $\mathrm{v}$ kazenskopravni zakonodaji, predvsem $\mathrm{v}$ okviru kaznivega dejanja razžalitve. ${ }^{13}$ Njihovo žaljivo izražanje o drugem namreč ni zajeto v nepravnostni biti kaznivega dejanja, če novinar drugo osebo razžali pri podajanju resne kritike ali pri opravljanju časnikarskega poklica. ${ }^{14} \mathrm{~V}$ takšnih primerih torej kaznskopravno varstvo odpade, oškodovana oseba pa mora poseči po drugih načinih za namene osebne retribucije. Sporno je, ali se ta izjema nanaša tudi na primere, ko je namen novinarja golo blatenje drugih oseb, zgolj zaradi tega, ker pri tem opravlja časnikarski poklic. ${ }^{15}$ Podajanje resne kritike in opravljanje časnikarskega poklica sta namreč v zakonu navedena kot dve ločeni izjemi. Če bi izjema opravljanja časnikarskega poklica zajemala samo tisto pisanje, ki hkrati pomeni tudi resno kritiko, katere objava je v javnem interesu, bi šlo za

\footnotetext{
9 Dejavnost medijev temelji na svobodi izražanja, nedotakljivosti in varstvu človekove osebnosti in dostojanstva, na svobodnem pretoku informacij in odprtosti medijev za različna mnenja, prepričanja in za raznolike vsebine, na avtonomnosti urednikov, novinarjev in drugih avtorjev pri ustvarjanju programskih vsebin v skladu s programskimi zasnovami in profesionalnimi kodeksi, ter na osebni odgovornosti novinarjev oziroma drugih avtorjev prispevkov in urednikov za posledice njihovega dela.

${ }^{10}$ Zakon o Radioteleviziji Slovenija (Uradni list RS, št. 96/05, 109/05 - ZDavP-1B, 105/06 - odl. US, 26/09 - ZIPRS0809-B in 9/14).

${ }^{11}$ Kodeks novinarjev Slovenije je bil sprejet 10. oktobra 2002, in sicer s strani novinarjev Slovenije, združenih v Društvu novinarjev Slovenije in Sindikatu novinarjev Slovenije. Dosegljiv je na sledeči povezavi: https://razsodisce.org/o-ncr/na-podlagi-cesa-ncr-deluje/novinarski-kodeks/.

${ }^{12}$ Glej (Day, 2005: 54-75).

13 "Kdor koga razžali, se kaznuje z denarno kaznijo ali zaporom do treh mesecev." Glej I. odstavek 158. člena KZ-1. Pri tem je treba omeniti, da ima večji del kaznivih dejanj zoper čast in dobro ime posebne, kvalificirane oblike deliktov za primere, ko so ti izvršene s pomočjo medijev. Glej na primer II. odstavek 158. člena KZ-1. Prav tako lahko v posebnih primerih za različna kazniva dejanja, ki jih niso izvršili sami, pod strogimi pogoji odgovarjajo celo odgovorni urednik, izdajatelj ali tiskar. Glej 166. člen KZ-1. Vendar te stroge določbe ne bodo prišle $\mathrm{v}$ poštev takrat, ko bo nepravnostna bit kaznivega dejanja razžalitve ali žaljive obdolžitve izključena že zaradi tega, ker je novinar opravljal časnikarsko dejavnost.

${ }^{14}$ » Ne kaznuje se, kdor se o kom žaljivo izrazi v znanstvenem, književnem ali umetniškem delu, v resni kritiki, pri izpolnjevanju uradne dolžnosti, časnikarskega poklica, politične ali druge družbene dejavnosti, obrambi kakšne pravice ali varstvu upravičenih koristi, če se iz načina izražanja ali iz drugih okoliščin vidi, da tega ni storil z namenom zaničevanja« «.( Tretji odstavek 158. člena KZ, Uradni list RS, št.50/12).

${ }^{15}$ Drugače Evropsko sodišče za človekove pravice, ki na primer govori o tem, da grotesken napad na ugled posameznika ni upravičena kritika (ang. fair comment) neke osebe, zaradi česar dopusti posege v svobodo tiska oziroma medijsko svobodo. Glej (Čeferin, 2013: 132).
} 
popolnoma redundanten zakonski znak. Takšna restriktivna razlaga bi ob tem izrazito škodila obdolžencu, kar je v kazenskem pravu lahko sporno.

Podobno izjemo lahko najdemo tudi $\mathrm{v}$ okviru kaznivega dejanja žaljive obdolžitve po 160. členu KZ-1,16 in sicer v primerih žaljivih obdolžitev, da je oškodovanec storil kaznivo dejanje, za katero se storilec preganja po uradni dolžnosti. Drugače kot pri kaznivem dejanju razžalitve pa mora v teh primerih novinar izkazati, da je imel utemeljen razlog verjeti v resničnost tistega, kar je trdil ali raznašal. ${ }^{17}$ Gre torej za zelo zanimivo prelaganje dokaznega bremena na obdolženca, ki v kazenskem in kaznovalnem pravu sploh velja za redko izjemo.

Ne glede na navedeno lahko novinarji neomejeno odgovarjajo za kazniva dejanja obrekovanja po 159. členu KZ-1,18 opravljanja po 161. členu KZ-119 in očitanja kaznivega dejanja z namenom zaničevanja po 162 . členu KZ-1. ${ }^{20}$ Vsi navedeni delikti imajo celo ločene, kvalificirane oblike deliktov za primere, ko je kaznivo dejanje storjeno s tiskom, po radiu, televiziji ali z drugim sredstvom javnega obveščanja ali na spletnih straneh.

Slovenski zakonodajalec pa tudi civilnopravno varuje ugled in dobro ime tako fizičnih kot tudi pravnih oseb (podjetij). Za okrnitev ugleda ali dobrega imena prisodi sodišče pravni osebi pravično denarno odškodnino neodvisno od povračila premoženjske škode, pa tudi če premoženjske škode ni, če spozna, da okoliščine primera to opravičujejo. ${ }^{21}$ Ta predpis je zlasti pomemben za škodljive medijske objave o podjetništvu, vendar se $\mathrm{v}$ praksi za te namene praktično ne uporablja.

\footnotetext{
16 " Kdor o kom trdi ali raznaša kaj, kar lahko škoduje njegovi časti ali dobremu imenu, se kaznuje z denarno kaznijo ali zaporom do treh mesecev." Glej I. odstavek 160. člena KZ-1.

17 "Če je bila žaljiva obdolžitev, da je oškodovanec storil kaznivo dejanje, za katero se storilec preganja po uradni dolžnosti, storjena v okoliščinah iz tretjega odstavka 158. člena tega zakonika, se storilec ne kaznuje za žaljivo obdolžitev, čeprav ni pravnomočne sodbe, če dokaže, da je imel utemeljen razlog verjeti v resničnost tistega, kar je trdil ali raznašal." Glej VI. odstavek 160. člena KZ-1.

18 "Kdor o kom trdi ali raznaša kaj neresničnega, kar lahko škoduje njegovi časti ali dobremu imenu, čeprav ve, da je to, kar trdi ali raznaša, neresnično, se kaznuje z denarno kaznijo ali zaporom do šestih mesecev." Glej I. odstavek 159. člena KZ-1.

19 "Kdor trdi ali raznaša kaj iz osebnega ali družinskega življenja kakšne osebe, kar lahko škoduje njenemu dobremu imenu, se kaznuje z denarno kaznijo ali zaporom do treh mesecev." Glej I. odstavek 161. člena KZ1.

20 "Kdor z namenom zaničevanja komu očita, da je storil kaznivo dejanje ali da je bil obsojen zaradi kaznivega dejanja ali to $z$ istim namenom komu pove, se kaznuje z denarno kaznijo ali zaporom do treh mesecev." Glej I. odstavek 162. člena KZ-1.

${ }^{21}$ »Za okrnitev ugleda ali dobrega imena prisodi sodišče pravni osebi pravično denarno odškodnino neodvisno od povračila premoženjske škode, pa tudi če premoženjske škode ni, če spozna, da okoliščine primera to opravičujejo.« Glej 183.člen Obligacijskega zakonika (OZ), (Uradni list RS, št. 97/07 - uradno prečiščeno besedilo, 64/16 - odl. US in 20/18 - OROZ631).
} 


\section{$4 \quad$ Funkcije medijev iz vidika podjetništva}

Funkcionalni pristopi $\mathrm{k}$ razlagi razmerja med množičnimi mediji in podjetništvom so osredotočeni na vlogo medijev $\mathrm{v}$ razvoju podjetništva $\mathrm{v}$ družbenem okolju ter na način, na katerega mediji posredno delujejo na družbeno politični sistem. Mediji lahko povečajo ugled podjetništvu in osebam, ki delujejo na tem področju, ali pa ugled teh oseb zmanjšajo oziroma ogrozijo. Krepijo lahko pomen družbenih norm, delujejo povezovalno in poudarjajo pomen družbenih vrednot, $\mathrm{v}$ nekaterih primerih (na primer $\mathrm{v}$ kriznih obdobjih) pa lahko delujejo disfunkcionalno in povzročajo nezaupanje $\mathrm{v}$ vrednostno strukturo podjetništva kot družbenega podsistema.

Medijsko poročanje javnosti o poslovanju podjetja pogosto odloča o uspehu ali neuspehu posameznikov, organizacij, družbenih skupin in celotnih družb. Kdor na trgu ne uspe opozoriti na sebe z uporabo uspešnih komunikacijskih tehnik počasi izgublja tekmo proti konkurentom na prostem trgu, kar je postalo tem bolj evidentno z vstopom Slovenije v EU. Na eni strani mediji vedno bolj dramatizirajo, da bi lahko ustvarjali želeni odziv javnosti, na drugi strani pa je javnost vse bolj preobremenjena z medijskimi vsebinami. »Galopirajoča inflacija besed« oziroma zasičenje javnega prostora $z$ informacijami povzroča vse manjše zaupanje javnosti, da s strani medijev objavljena besedila temeljijo na nečem resničnem, objektivnem, avtentičnem. (Kunczik \& Zipfel, 2006: 60).

$\mathrm{V}$ literaturi lahko zasledimo predvsem sledeče funkcije medijev $\mathrm{z}$ vidika podjetništva:

- večanje ugled in avtoritete posameznikov ali skupin na podlagi legitimiranja njihovega družbenega statusa (statusna funkcija, ang. status conferral function);

- krepljenje družbenih norm (funkcija etiziranja, ang. ethicizing function) ter

- v nekaterih okoliščinah tudi disfunkcionalno delovanje, saj lahko mediji povzročijo neustavnost in pasivnost (ang. narcotization). 
Posebej se opozarja na funkcijo komunikacije, ki se nanaša na stabilizacijo sistema, ki podpira dominantne vrednotne strukture, prek:

- nadzora okolja (ang. surveillance of the environment);

- odnosa med deli družbe in njeno celoto (ang. correlation) ter

- prenosa socialne in kulturne dediščine na naslednjo generacijo (ang. transmission) (Kunczik \& Zipfel, 2006: 37).

\section{$4 \quad$ Vsebina razprave na okrogli mizi}

O povezanih temah je tekla razprava tudi na mednarodnem srečanju Gospodarski subjekti na trgu. Uvodoma sta govorca poudarila, da imajo mediji v družbi strahovito moč, saj delujejo kot četrta (neformalna) veja oblasti in v tej vlogi pogosto odstopajo od svoje temeljne funkcije obveščanja javnosti in pri tem, kot vsaka oblast poskušajo vzpostavljati svojo voljo skozi razne oblike izražanje mnenj, svetovanj in (medijskega) sojenja na podlagi osebnih meril, s čimer soustvarjajo javno mnenje. $\mathrm{V}$ tem kontekstu gre za tako imenovano medijsko sojenje brez možnosti obrambe. Oblikovanje in vpliv na javno mnenje je v demokratičnih družbah lahko pozitivno ali negativno z vidika ciljev, ki jih družba zasleduje. To je še posebej pomembno za podjetništvo, ki je po naravi stvari občutljivo na gibanje javnega mnenja, pri čemer pa je obstoj in uspešno delovanje podjetništva conditio sine qua non za razvoj sodobne družbe. Ob vsem tem pa se je položaj tradicionalnih medijev v družbi zaradi razvoja informacijske tehnologije pred 20 leti pričel bliskovito spreminjati. Vstopili smo v turbulentno obdobje, ki ogroža njihovo tradicionalno razumljeno vlogo ali celo njihov obstoj, na kar tradicionalni mediji niso bili pripravljeni.

Mediji so udeleženci na prostem trgu in so zaradi tega pogosto v konkurenčnem razmerju do ostalih tekmecev, vendar se sklicujejo pri bitju tega boja pogosto sklicujejo na posebni položaj in vlogo medijev v strukturi družbe in želijo ta privilegirani položaj obdržati tudi v prihodnje. Drugače: medijem odgovarja dominantni položaj znotraj družbene strukture. Pojavlja se tako imenovani medijski nibilizem, kar pomeni, da pri svojem delovanju mediji ne priznavajo nobene družbene vrednote. Zanikanje ali zavajanje o resničnih dejstvih zaradi tega postane splošno sprejeti pristop. Nihilizem medijev gre roko v roki s splošnim nezaupanjem $v$ medije, čeprav je takšno zaupanje javnosti v medije lahko nova valuta uspeha, kot se navaja v eni od zadnjih številk World Press 
Trends 2017. Najnovejši pojav »lažnih novic" ( ang. fake news)22 in dezinformacije na družbenih omrežjih se tako iz spletnih strani s sumljivimi naslovi in družbenih omrežij seli tudi med elitne, tradicionalne medije. ${ }^{23}$ Tako ne more biti presenetljivo, da tudi slovenska pravna teorija govori o tem, da smo v obdobju razpada realnosti. "Resnica je $\mathrm{v}$ dobi množičnih medijev, ki so jo venomer izkoriščale politične sile, že dolgo sneta s tečajev [...]. Pojav fake news je s [...] tehnologijo dobil le bolj strašljivo algoritmično podobo. [...] Nekateri zato svarijo pred apokaliptičnim informacijskim zlomom (ang. infocalypse) kot zlomom trga idej, na katerem nihče ne verjame ničemur - ali vsi verjamejo lažem." (Završnik, 2018: 23).

Ravno pri medijih, ki poročajo o podjetništvu, gre pogosto za izkrivljanje informacij ali dejstev oziroma za fiktivne informacije, kar pa pomeni vrhunec degeneracije medijskega prostora in ogrožanje osnov zaupanja $\mathrm{v}$ podjetništvo. Izguba zaupanja $\mathrm{v}$ medije narašča $\mathrm{v}$ obliki skepticizma, brezbrižnosti ali celo cinizma, ki je lahko uperjen tako proti medijem kot proti podjetnikom in podjetništvu.

Mediji torej še vedno razpolagajo $z$ veliko mero moči (usmerjanje družbenega diskurza in javnega mnenja), vendar se ta moč pogosto zlorablja. Pomemben del družbenih institucij 20. stoletja trpi zaradi izgube zaupanja, pri čemer so mediji med najbolj prizadetimi. Zato ne more biti sporno, da smo pred temeljnimi spremembami, pred oblikovanjem novega medijskega sveta. Ne gre samo za objavljeno vsebino, ampak predvsem za strukturne spremembe v samih medijih. Vpliv medijev v ekonomiji, družbi, proizvodnji, upravljanju ali ustvarjanju vrednosti se je popolnoma predrugačil. ${ }^{24} \mathrm{~V}$ orisanih pogojih se je realno in

\footnotetext{
22 Pri tem tudi domača teorija opozarja, da je nejasno, kaj pojem lažne novice (ang. fake newss) sploh zajema. "V predpisih trenutno ni moč zaslediti opredelitve tega pojma, pa tudi normativna pravila $\mathrm{v}$ zvezi z lažnimi novicami so redka. To velja tako za slovenski pravni red kakor tudi za primerljive pravne sisteme. Da je celo na evropski ravni vse skupaj šele v začetni fazi, kaže nenazadnje deklaracija Evropskega parlamenta iz junija 2017, $\mathrm{v}$ kateri ta Evropsko komisijo poziva, naj opravi analizo stanja in 'preveri možnost zakonodajnega posega za omejitev razširjanja lažnih vsebin'." (Pohar, 2018: 6; Tomažič, 2018: 17).

23 Problematiko v slovenskem prostoru analizira tudi Teršek, ki zapiše sledeče (Teršek, 2018: 16): "Ima javnost pravico prejemati verodostojne informacije? [...] Očitno je, da se je v tako imenovani postfaktični družbi prav ta paradigma obrnila. Modra se je obrnila na glavo. Morda je postala svoje nasprotje: mediji, informiranje in svoboda izražanja nimajo ne teoretično ne praktično ničesar normativno prisiljujoče nujnega opraviti z dejstvi in z resnico. [...] Zato je treba resno podvomiti, ali tudi teoretično sploh še velja, da je vloga tiska posebej pomembna pri pospeševanju politične in drugih vrst javne razprave.".

${ }^{24}$ Splošno znano je, da morajo mediji pri produkciji in distribuciji medijskih vsebin upoštevati večinsko mnenje v družbi. Problem v naši družbi je ta, da še vedno o podjetništvu nimamo jasno izoblikovanega pozitivnega javnega mnenja zaradi prisotnih usedlin socialistične preteklosti. Mediji zaradi tega na nek način živijo v strahu. Če bi nastopali z novimi vsebinami pozitivnega pristopa podjetništvu, bi to namreč lahko sprožilo zavračanje medijskih vsebin in povzročilo finančno izgubo. V luči javnega interesa do obveščenosti bi uporabniki medijev
} 
smiselno vprašati, v kakšno smer se mediji razvijajo in kakšna bo njihova vloga ter modus operandi v prihodnosti? ${ }^{25}$

V Sloveniji so mediji v krizi, ki je doslej nismo poznali. Pesti jih teza, ki jo novinarji namerno ali ne vsiljujejo javnosti, da »novinar vse ve« in da je poklican, da nadomešča organe pregona in preiskav ter da lahko svetuje poslovodstvu kako in kaj naj dela. Pojavlja se v vlogi varstva delavcev, kjer so delodajalci praviloma prikazani $\mathrm{v}$ negativni luči. Biti podjetnik na splošno ima $\mathrm{v}$ družbi negativen moralni predznak. $K$ temu nedvomno prispevajo tudi mediji. Zlasti se to vprašanje pojavlja $\mathrm{v}$ zadnjem času, ko nekateri predstavniki državnih institucij obravnavajo lastnike kapitala $v$ negativnem kontekstu svojih izjav (znane so na primer sporne izjave posameznih predstavnikov pravosodja in napovedi nekaterih političnih predstavnikov o potrebi, da se podjetnikom odvzame premoženje). ${ }^{26}$

Posebej zaskrbljujoče pa je pri tem to, da se nekateri podjetniki v medijih obravnavajo pozitivno, nekateri pa apriorno negativno. $\mathrm{V}$ takšnem okolju nihče ne ve, kdo je danes pravzaprav "tajkun", kdo pa je dober podjetnik. Ali za prvo in drugo kategorijo obstajajo jasni kriteriji? Znano je, da posamezniki, ki soustvarjajo javno mnenje, zahtevajo za pozitivno mnenje posebne nagrade. Nadalje prihaja tudi do različnih oblik izsiljevanja, ko nekateri ne želijo, da bi bilo objavljeno kašno slabo mnenje o določenem podjetju oziroma o lastnikih kakšne gospodarske družbe. ${ }^{27}$ Tako se mnogi sprašujejo, kje je meja med podjetnikom s

morali biti zavarovani pred komercialno logiko, ki tako nekritično vodi medije pri izbiri in oblikovanju vsebin ter načinu njihovega posredovanja javnosti.

${ }_{25}$ Denis Teyssou, vodja inovativnosti za video projektiranje INVID in vodja oddelka za raziskave in razvoj AFP Medialab na je na IFRA World Publishing Expo in Digital Content Expo v Berlinu leta 2017 napovedal izvajanje novega projekta preverjanja resničnosti oziroma neresničnosti objavljenih medijskih dejstev, ki naj bi se začel izvajati leta 2018. V projektu bi naj sodelovali novinarji, raziskovalci in člani akademske skupnosti pod geslom ,in video, there is truth“. Projekt ima za cilj hitro pomoč in pogled dejstev, da bi se tako izogniti lažnim novicam. Preverjanje dejstev je namreč najpomembnejši del verodostojnega novinarstva. Podrobneje glej (Gavranović, 2017), v celoti.

${ }^{26}$ Glej na primer prispevek z naslovom Škandalozno: tožilec Kozina v slogu tovarišev Levice poziva k zlomu moči kapitala in obdavčitvi podjetnikov. Dostopno na: https://reporter.si/clanek/slovenija/skandaloznotozilec-kozina-v-slogu-tovarisev-levice-poziva-k-zlomu-moci-kapitala-in-obdavcitvi-podjetnikov-663018.

Objavljeno 3. 10. 2018.

${ }^{27}$ Steinbuch $\mathrm{v}$ prispevku z naslovom Sedem let kasneje piše o pojavu izsiljevanja novinarjev podjetij: »Ni se mu zdelo prav nič nemoralno, če je obiskal katerega izmed direktorjev velikih (državnih) podjetij, mu pokazal že napisan, a še ne objavljen članek, in se pogodil za oglas. Ni bil edini urednik, ki je to počel. Nekateri to počnejo še danes. Nekateri niso prodali samo strani v svojem mediju ali oglasa, pač pa ves medij. Nekateri so v tem času postali večina. Kdaj natančno se je to zgodilo, ne vem. Vendar se je zgodilo in žurnalizem je v Sloveniji padel tako nizko, da bi se, če bi premogli vsaj delček Slivnikovega občutka za čast, lahko v glavo ustrelil ducat urednikov in medijskih lastnikov. Takšen je ta svet, veste. Nobene romantike ni v njem." Glej (Steinbuch, 2019), v celoti. 
pozitivnim predznakom in tistim, ki bi ga naj obravnavali kot "tajkuna" oziroma negativnega nosilca podjetništva (Veselič, 2019), v celoti.

Splošno znano je, da lahko pri poslovanju kateregakoli podjetja pride do napak, ki jih bo nadobuden in vztrajen novinar slej ali prej tudi odkril. Takšne napake je mogoče javnosti prikazati kot zelo pereče in usodne in na podlagi njih kazati na negativne lastnosti in slab karakter ljudi, predvsem podjetnikov. Razumljivo je, da takšen pristop odbija določene bralce, kot odbija tudi tiste, ki se »bojijo« medijev, saj jih medij lahko podjetniško uniči. Ogrozi lahko ugled in dobro ime gospodarske družbe kot tudi posameznika, ki nastopa kot lastnik podjetja ali pa ima določeno funkcijo znotraj organa vodenja oziroma nadzora gospodarske družbe. ${ }^{28}$

O podjetništvu imajo stereotipno negativno mnenje zlasti pravniki, ki niso nikoli prestopili praga tovarne ali bili vključeni $\mathrm{v}$ podjetništvu. Drznili si bomo predpostaviti, da se to nanaša tudi na novinarje, ki vidijo $\mathrm{v}$ podjetništvu le nevarnost kriminalnega početja na škodo družbe in delavcev. Današnji pregon "tajkunov", pri čemer nihče zares ne ve, na koga naj vi se ta pojem sploh nanašal, je frapantno podoben socialističnemu pregonu kulakov. Podjetništvo naj bi bil po zamisli zakonodajalca, kateremu sledijo zlasti kabinetski pravniki v pravosodju in izvršilnih organih oblasti, idealni družbeni pravni sistem, ki ne pozna izjem in spreminjevalnih okoliščin na trgu. Zakonodajalec je prepričan $v$ nujnost normiranja vseh mogočih položajev in ravnanj, kar je posledica zahtev tistih, ki nadzorujejo poslovanje podjetij $\mathrm{z}$ namenom izvajanja sankcij. Podjetniki nasprotno želijo več manevrskega prostora in normativnih načelnih rešitev, ne pa nepreglednega števila zelo specialnih in podrobnih pravnih predpisov, ki so v stalnem spreminjanju. ${ }^{29}$ Obsežnost pravnih predpisov predstavlja za podjetnika breme, ki ga težko razume in tudi finančno trpi, saj skorajda vsak (tudi manjši)

\footnotetext{
${ }^{28}$ Če želimo mlade spodbuditi, da se podajo na pot podjetništva, od katerega živimo, jim ne smemo vsiljevati naše mnenje o apriornem slabem kapitalizmu, o čemer smo, vsaj starejše generacije, poslušali desetletja. Kapitalizem oziroma podjetništvo, kar koli razumemo pod tem pojmom, ni moralen in tudi ne nemoralen, ni pozitiven niti negativen on je preprosto družbeno ekonomski sistem, ki je nevtralen z vidika moralnih vrednot (amoralen). Zato je nevarno početje, če podjetništvo poskušamo moralno ovrednotiti. Predmet moralnega družbenega vrednotenja so lahko je dejanja ljudi, ki pa morajo imeti znanja in lastne izkušnje na področju, o katerem želijo izrekati moralne sodbe.

29 Pravna teorija v tem smislu govori tudi o problemu hipertrofije pravnih norm, ki ga je v odklonilnem ločenem mnenju, kateremu se je pridružil tudi E. Petrič, izpostavila ustavna sodnica E. Korpič - Horvat. O hipertrofiji pravnih predpisov govorimo, ko določeno pravno vprašanje ureja veliko število formalnih pravnih virov. To lahko posledično prispeva $\mathrm{k}$ neenotni sodni praksi in posredni $\mathrm{k}$ zmanjšanju pravne varnosti. Posebej problematično je veliko število pravnih predpisov v primeru, da določenega vprašanja ne urejajo sistematično, da nastanejo v kratkem obdobju in vsebujejo nejasne določbe. Glej odklonilno ločeno mnenje sodnice E. Korpič - Horvat v zadevi US RS, Odločba U-I-185/10, Sklep Up-1409/10.
} 
podjetnik potrebuje pravnika, če želi spoštovati vse predpise pri poslovanju. Medijem pa takšna situacija gre na roko, ker jim je enostavno primerjati poslovanje podjetnika in $\mathrm{z}$ njegovo dolžnostjo izpolnjevanje nepreglednega števila pravnih norm, katerih neupoštevanje je lahko povezano tudi z izrekanje različnih vrst sankcij.

Čeprav zakonodajalec glede na nepravnostno težo oziroma zlo, ki veje iz kaznivega ravnanja, ločuje med prekrški in kaznivimi dejanji (glej Bavcon in drugi, 2013: 43-44), pa tudi kazniva dejanja se med seboj drastično razlikujejo glede na nepravnostno težo poškodbe oziroma ogrozitve kazenskopravne dobrine, se v medijih to običajno ne poudarja. Praviloma se v medijih navaja, da je podjetnik kršil zakon in kakšna je višina zagrožene kazni oziroma globe. Za javnost, ki ne pozna omenjenih razlik med prekrški in kaznivimi dejanji, pomeni omenjanje najvišje kazni sporočilo o težkih in zelo zavržnih kršitvah. Tako mediji zaradi nepoznavanja omenjene problematike pošiljajo $\mathrm{v}$ javnost zastrašujoča sporočila, ki zlasti negativno vplivajo na mlade podjetnike. Mediji nadalje ne ločujejo med dolžniki, ki so pravi dolžniki, od »dobrih dolžnikov«. Med »dobre dolžnike« pravniki štejemo zlasti poroke, hipotekarne dolžnike, in druge osebe, ki podjetnikom zaradi družinskih in prijateljskih ali poslovnih namenov želijo pomagati pri prevzemu obveznosti ali s pristopa k dolgu. Takšne osebe so na nek način dolžniki "žrtve" in jim zaradi tega treba izkazovati primerno hvaležnost, saj so svoje premoženje žrtvovali za reševanje podjetja drugega. Medijo pa venomer navajajo dolžnike, ne da bi med njimi razlikovali dolžnike, ki so posredno oškodovani zaradi svoje pripravljenosti pomagati drugim. V Mariboru so mediji obsojali direktorja, ki je pomagal poslovnim partnerjem v težavah s prevzemom poroštva, in ga obravnavali kot kriminalca, čeprav je v osnovi bil žrtev objektivne krize, njegova želja pa je bila pomagati drugim osebam. Tudi če je pri tem storil napako oziroma nevede ravnal v nasprotju s pravom ga ne glede na to ni pravilno obravnavati enako kot tistega, ki je povzročil škodo podjetju zaradi svojih osebnih koristi.

\section{Družbena omrežja in podjetništvo}

Družbena omrežja v različnih pojavnih in organizacijskih oblikah so nesporno izzvala revolucijo na medijskem področju. Ne glede na to je težko odgovoriti na vprašanje, kaj družbena omrežja sploh so. Pojavila so se bliskovito (z zornega kota mnogih pravnikov praktično "iz ničesar") in počasi spremenila svet komunikacije pri posredovanju informacij. Prisotna so na vseh področjih 
družbenega življenja. Ni sporno, da ogrožajo obstoj in delovanje tradicionalnih medijev ter jih prisiljuje $\mathrm{k}$ temu, da sprejmejo nekatere oblike delovanja, ki jih je težko opredeljevati s kakršnim koli negativnim ali pozitivnim predznakom. "Na [družbenih] omrežjih vsi vedo vse o vseh in vsi o vseh tudi sodijo, družabni mediji so hudič z obrazom angela." 30

Dostopnost družbenega omrežja omogoča bistveno lažje posredovanje informacij o podjetništvu javnosti. $\mathrm{V}$ glavnem so mnenja o podjetništvu in podjetniki negativna in izjemoma se pojavljajo zapisi, ki pozitivno ocenjujejo delovanje podjetništva (Škarja, 2013), v celoti.

Pojav družbenih omrežij, ki danes postaja eno od pomembnejših medijskih področij, potrebuje celovito in domišljeno pravno regulativo, ki danes vsaj $\mathrm{v}$ našem prostoru žal ne obstaja. Uvajanje novih tehnologij na področje medijev namreč pravno stroko postavi pred vrsto novih vprašanj, katerih odgovori nemalokrat terjajo tudi določeno znanje in razumevanje informacijsko komunikacijske tehnologije. Na ta vprašanja ne morejo odgovoriti pravniki, ki so bili izobraženi $v$ preteklem sistemu. Namesto tega je treba izobraziti novo generacijo pravnikov in drugih strokovnjakov za medijsko področje, ki so neobremenjeni s preteklostjo. Prav ta nova, neobremenjena generacija bo bolj učinkovita pri iskanju odgovorov na novodobna vprašanja medijskega prava. ${ }^{31}$

V okviru razprave na omenjeni okrogli mizi je le obrobno bilo govora o vlogi družbenih omrežij na področju podjetništva. Zaradi vse večje prisotnosti razprav o podjetništvu, zlasti na Facebooku, posredujemo nekaj zapisov, ki smo jih našli na tej straneh omenjenega medija $\mathrm{v}$ obliki razmišljanja in komentarjev. Iz te zapisov je mogoče na splošno, vendar z določeno zadržanostjo, ugotoviti, kako posamezniki razmišljajo o vprašanjih podjetništva. ${ }^{32}$

\footnotetext{
30 Glej prispevek z naslovom Francoska diva Isabelle Adjani proti družbenim medijem. Dostopno na: https://www.rtvslo.si/zabava/iz-sveta-znanih/francoska-diva-isabelle-adjani-proti-druzbenimmedijem/463089. Objavljeno: 13. 8. 2018.

31 Društvo za medijsko kulturo se še posebej ukvarja s fenomenom družbenih omrežij. Tako je na primer predsednik društva, asist. Jan Stajnko, septembra 2018 v okviru mednarodnega projekta "Snapshots from the borders - No more bricks in the wall" izvedel predavanje o sovražnem govoru z naslovom Razne oblike spodbujanja etnične in rasne nestrpnosti - kaznivo dejanje po Kazenskem zakonu Republike Slovenije.

32 Pri pisanju tega prispevka smo pobrskali po Facebooku in našli vrsto zanimivih razmišljanj o podjetništvu. Tukaj jih navajamo brez podatkov o imenih avtorje in komentatorjev, ker jih je mogoče najti na raznih statusih prijateljev na tem družbenem omrežju. Največ jih je mogoče prebrati na (Škarja, 2013), v celoti.
} 
"Ajej, ajej ... Žalostno, da je v naši ljubi Sloveniji biti PODJETNIK nekaj slabega v očeh večine dr:̌avljanov. Č želiš biti cenjen, moraš biti reven, brez usega, ubogi, samo dajati in nič sprejemati.

A ni tako, da bi morali biti ponosni na podjetnike, ki uspejo? A ni bolj cenjeno, da se nekdo zna sam preživeti in ni doma na račun socialne pomoči? A niso spoštovanja vredni podjetniki, ki omogočijo nova delovna mesta in tako prě̃ivetje mnogim ljudem?

A splošno prepričanje je, da je podjetnik nekaj negativnega.

Mi je prav budo za vse naše uspešne podjetnike, ker vem, koliko se morajo prematrati, koliko noči ne spijo, koliko se presekirajo, koliko stresa doživljajo, da imajo take uspehe.

Japec Jakopin (podjetje Seaway) je lepo povedal na dogodku 500 podjetnic - ko je bil profesor na fakulteti, je bil zelo cenjen, spoštovan. Ko je šel v podjetništvo, je bil kar naenkrat "popljuvan". A on se ni spremenil, v obeh primerib je bil ista oseba."

Na žalost so nam medïi približali napačno predstavo podjetnika - da je to oseba, ki bogati na račun drugih, da je to oseba, ki laže, krade, prelisici vse zakone in da je to oseba, ki nima morale. Podjetništvo se v Sloveniji danes enači z. negativnim tajkunstvom.

Pa razmišljajmo drugače: ali je res pravično obsojati ljudi, ki so sposobni zaslužiti denar zase in za svoje življenje? A je res pravično imeti negativno podobo o človeku, ki je sposoben ustvariti 50 delovnih mest in tako "preživlja" 50 drǔ̌in? Ali je res pravično imeti pozitivno mnenje o ljudeh, ki finančno nimajo nič, ki rivijo v revščni in prejemajo socialno pomoč, so to res bolj cenjeni ljudje kot tisti, ki delajo za to socialno pomoč drugih in ki ustvarjajo nova delovna mesta, da je vsem bolje? A je res pravično use ljudi metati v isti koš na podlagi nekaj medijskih zoodb tajkunstev in prevar med bogataši (mediji to pišejo, ker to ljudje radi berejo, saj stem išcejo krivdo za lasten slab položaj v drugib)?

Sama imam iquedno pozitivno mnenje o podjetnikih. V življenju sem prepričana, da "vesolje" JE pravično. In vse se povrne - vse dobro in vse slabo. In uspešni podjetniki, katere osebno poznam, imajo vsi, ampak res vsi, izredno mocno pozitivno osebnost, kvalitetne misli in dobre namene.

Tisti, ki tega nimajo, slej kot prej propadejo ali se jim povrne nekako drugače. In tajkuni, o katerih veliko govorijo mediji, so večinoma menedžerji in ne podjetniki. kakšna je razlika? Bistvena! Podjetniki razpolagajo z lastnim denarjem in prevzemajo riziko lastnega denarja. Mened žerji pa upravljajo z. denarjem firme, kjer so zaposleni. zato je mnogim (tem, o katerih 
se piše po medijih) bolj malo mar, kar je s podjetjem zoodi. To ni njihov "otročiček", kakor za lastna podjetja čudijo podjetniki.

Naj naštejem le nekaj komentarjev na FB strani, ki so mi še posebej v̌reč in jih 100\% podpiram:

"Spoštujmo vse, ki dobro delajo in prinašajo v državno blagajno potrebni denar, da država splob obstaja. Posnemajmo jih. Opustimo slovenski nacionalni šport, imenovan Zavist." "Jaz. pa ravno kontra od napisanega razmišljam. Mislim, da bolj ljudje razmišljajo, kako je podjetnikom oz: samozaposlenim simpl pa fajn. Brez šefa, nič se ne matraš, denar pa kar na kup leti. Pa ni ravno tako ..."

"Ljudje s(m)o si ustvarili tako mnenje o podjetnikih zaradi tistih, ki so obogateli na račun drugih. Tistih, ki so iz okolja samo jemali in nič vračali. Na srě́o, je vedno več takih, ki razumejo, da podjetje brez zadovoljnih delavcev in povezanosti zokoljem ne more obstati. Ti poćasi a vžtrajno rušijo ta negativni stereotip."

"Ne gre zato, ali boš zbrisal, gre za način razmišljanja in odnos, ki je v tem primeru negativen. Kar spušcamo od sebe, to se nam vrne nazaj. To pa le imejte v mislih vsi, ki negativno razmišljate, ki drugim ne privošcite, ki vas je strah, ki vidite le slabo. Odprite ori in poglejte, koliko dobrega, uspešnega je tudi okrog nas. Zaslepljeni od samih slabih dnevnih novic iz. medijev, iz." "revolver" časopisov, ki si višajo naklado z lažmi, natolcevanjem, polresnicami. Kar je slabega in protizakonitega storjenega, pribaja na svoj obračun. To ste že labko opazili. Zdaj pa $v$ mislih in srcih podprite vse uspešne, inovativne, pridne in poštene ljudi. Ki si ZASLUŽIJO biti bogati, tako kot sleherni izmed nas na tem planetu. Živeti v obilju je pravica vsakega Zemljana in ni nič slabega. V sem vse pripada, dovolite si to. Ce mislite, da v naši drăavi nimamo poštenih, pridnih in sposobnih podjetnikov, ne živite v pravi državi."

"Ko bi od malega vagajali otroke, da je samostojno nekaj zaslụ̌it fajn. Da s svojim delom labko dostojno živiš (le od k.je ideja, da so podjetniki bogataši :/) pa bi bilo v Sloveniji manj brezposelnih, manj revežev, pa še kdo bi znal kaj naredit."

"MEDIJI! So po mojem mnenju krivi za to, da ljudje razmišljajo tako. Medïi ne znajo govoriti skoraj nič drugega kot samo o slabih stvareh, ki se dogajajo na področju podjetništva, kot na splošno o vsem drugem. Č bi od danes naprej mediji govorili samo oz. največ o uspešnih podjetnikih in njihovimi uspebih in bolj pozitivno usmerjeno, bi ljudje začeli razmišljati drugače, bolj pošteno in najverjetneje bi bilo več podjetnikov." 
"Popolnoma se strinjam o medijih. A kaj labko mi storimo v zvezi s tem? Da pišemo in govorimo o uspešnih, dobrih, podjetnih in poštenih podjetnikih. Pobvalimo jih, dajmo jim priložnost, da jih svet bolje spozna, vidi, slisi zanje. Koliko inovatorjev imamo, med zelo mladimi. Koliko uspešnih podjetij, saj vendar nekdo vz̨ržuje to državo! Od kje pa se napaja, če ne od profita uspešnih? Razmišljajmo ven iz ozkih okvirjev in pošteno. Vedno so bile in bodo lopovšrine, dokler je svet tak, kot trenutno š je. A vedno so bili, so in bodo tudi uspeŕni. In teh je več. Saj nas drugače že ne bi bilo. Izkorišcani po celem svetu se upirajo in velike spremembe se že dogajajo. Ozrimo se naokrog in stopimo v korak s to energijo. Namen je tisti, ki prinese uspeh. Cepeti za zapečkom, kritizirati in stokati pa žal nič, temveč le poglabljanje slabega. Ne le podjetnikov, tudi osebnega."

"Med podjetniki mislim, da je največ tistih, ki imajo "jajca" (pa ne mislim velikonočnih), Zame je "pravi" podjetnik tisti, ki je iz hobija ustvaril "svoj poklic"), ki vidi napake in si ̌̌eli ponuditi več in boljšse.

Tisti, ki je pripravljeni delati petek in svetek, ki se odpoveduje dopustom, praznikom ... zato da vizija, ki si jo je začrtal, uspe...

To so ljudje, ki ne čakajo 15-ga na plačo, ki ne vedo kedaj, če sploh, jo bodo imeli. Tisti, ki jim je plačilo že redka, a zadovoljna stranka ... To so ljudje, ki ponoči bedijo in razmišljajo, kaj bi še labko in na kakešen način ... To so ljudje, ki delajo desetletja, da uspejo "čez nočl"

To so ljudje, ki so pod stresom 24 ur/dan ... in četudi sedijo na sončku na kavi s svojo dru民̌inico, planirajo, kaj vse jïh čaka v naslednïh trenutkih ...

So ljudje, ki namesto za režervacijo podaljšanega vikenda, sredstva vložijo v reklamo ali izboljšanje osnounih sredstev ali za nove sodelavce.

To so ljudje, ki se zavedajo, da so le sami odgovorni za svoj blagor in se ne zanašajo na nič in nikogar.

A redki, ki so uspeli čez noč, imajo tudi mnogo, mnogo več... a prepričana sem, da so desetletja bodili po isti poti.

Se pa ̌̌udim, da re je tako fino in enostavno biti podjetnik, da jïh ni več?"

"Pa da se š jaz oglasim strinjam se, da so mediji delno krivi za takšnno mišljenje, po drugi strani pa tudi cloveška lenoba. Toliko informacij nam je na voljo, toliko znanja, ki je zaenkerat se na voljo na internetu... Večina pa ne vidi dlje, oz ne posrfa dlje od najbolj branega 
novicarskeega portala v slo, ki pa rivivi od 'ekskluzivnib', 'škantnib', 'krvavib' in negativnih prispevkov. In potem se čndimo vsej negativi? Če bi samo malo uporabili glave, kritično presodili in Tovšakove gospe ne posploševali na use podjetnike bi bil svet takoj lepši. Aja, pa nehajmo gledati dnevnik in ves negativižem, meni je ̌̌̀ 5 leto super brez TV-ja.

Hehe, tale je res dobra: "Se pa ̌̌udim ... da če je tako fino in enostavno biti podjetnik ... da jïh ni vec?"

Mislim, da ne rabim več veliko dodati, saj so ti komentarji povedali, kar tudi sama mislim o tej tematiki. Je pa v osnovi tako: Ce ima clovek slabo mnenje o bogatih, ne bo nikoli bogat (za nekoga to pomeni 1000 eurov mesečno, za drugega milijon mesě́no). In če ima človek slabo mnenje o denarju, ga nikoli ne bo imel. Ampak, ko pridejo položnice na dom, ga ima pa vsake rad $v$ řepu in tako pribrani stres, negativnost in slabo voljo, kar prenaša tudi na druge družinske clane. A ni tako.?"

\section{$6 \quad$ Medijsko poročanje v kazenskih postopkih}

Posebna dilema, ki se pretežno nanaša na fizične osebe, prav tako pa je možna tudi pri pravnih osebah, je kdaj lahko organi pregona poročajo medijem o preiskovanju kaznivega dejanja in koliko informacij lahko $\mathrm{v}$ takih primerih posredujejo medijem.

Pomemben del medijskega poročanja je namreč obveščanje javnosti o kazenskih postopkih, s čimer mediji omogočajo posredno nadziranje delovanja sodne oblasti s strani ljudstva. Glavne obravnave so javne, tako da jim lahko vsakdo prisostvuje (z izjemo kadar je javnost izključena) (Dežman \& Erbežnik, 2003: 258-261). Ena ključnih dilem poročanja $\mathrm{v}$ kazenskih postopkih, ki je tako v teoriji kot praksi zelo zamegljena, pa je, kdaj mediji dejansko lahko začno poročati o samem kazenskem postopku? Že v fazi, ko neko zadevo, ki bi lahko bila kaznivo dejanje, preučuje policija? Ali morda ko se uvede faza preiskave, kjer je določena oseba že osumljena določenega kaznivega dejanja? Ali morda šele ko državni tožilec vloži obtožnico in ta postane pravnomočna, kar pomeni, da bo kazenska zadeva dobila svoj epilog v sodni dvorani na glavni obravnavi?

Ta vprašanja so ključna tako za delo novinarjev, kot za delo organov pregona, saj morajo biti jasno določene meja, kdaj lahko organi pregona novinarjem predajo informacije o vodenju kazenske zadeve, in kdaj morajo določene podatke in informacije o vodenju kazenskega postopka ohraniti kot tajne. 
Kot primer vzemimo gospodarsko družbo, kjer naj bi se domnevno zgodilo neko kaznivo dejanje - npr. oškodovanje upnikov po 227. členu Kazenskega zakonika (KZ-1). ${ }^{33} \mathrm{Na}$ sedež podjetja prispe policija, ki začne s preiskovanjem domnevnega kaznivega dejanja, prav tako pa tudi novinarji, ki jih zanima, kaj se je zgodilo, da bi napisali kar se da zanimivo in šokantno zgodbo. Slednjim je zagotovo $\mathrm{v}$ interesu, da bi lahko poročali o čim bolj šokantni aferi s hudimi kaznimi dejanji in z vpletenimi čim bolj pomembnimi podjetniki, saj bo to bistveno povečalo branost njihovega medija, $v$ primerjavi z novico, da se je zgodil nek zanemarljivi prekršek, za katerega bo podjetje plačalo 500 evrov globe.

Tako medijsko poročanje o domnevnem kaznivem dejanju zagotovo zelo prizadene zasebnost in dobro ime posameznikov ter gospodarskih družb. ${ }^{34} \check{C}_{\mathrm{e}}$ se bo kasneje izkazalo, da podjetnik ni storil nič kaznivega, mediji pa so že na veliko poročali o njegovih domnevnih kaznivih dejanih, in to v času ko vse skupaj preiskuje le policija, na podlagi najnižjega dokaznega standarda, s katerim država utemeljuje, da je določena oseba zares izvršila določeno kaznivo dejanje, bo podjetnikovo ime neupravičeno uničeno, na podlagi nekakšnih sumničenj in klevet, brez kakršnihkoli resnih dokazov, ki bi ta sumničenja podkrepila in opravičila interes javnosti, ${ }^{35}$ da se o tem na veliko poroča. Znano je, da ko mediji o nekom poročajo $\mathrm{v}$ povezavi s kaznivim dejanjem, javnost slednjega pogosto dojema kot da je že obsojen za to kaznivo dejanje. Soočamo se s pojavom medijskega sojenja, ki poteka povsem izven okvirov sodnega sojenja. Za uničenje dobrega imena posameznika namreč ne potrebujemo pravnomočne kazenske obsodbe, zadostuje že obsežno poročanje o zadevi!

Ko primer iz prakse lahko vzamemo dejanski primer ljubljanskega župana Zorana Jankovića, katerega je policija (Nacionalni preiskovalni urad) preiskovala glede številnih kaznivih dejanj. ${ }^{36} \mathrm{~V}$ avgustu leta 2017 je spletni portal Pod črto pridobil kopije kazenskih ovadb, ki jih je zoper njega pripravil Nacionalni preiskovalni urad. V ovadbah je Janković osumljen pranja denarja in preslepitve bank v zadevi Stožice, utaje davkov pri prodaji delnic Mercatorja in posredovanja pri zaposlitvi farmacevtke $\mathrm{v}$ stiski $\mathrm{v}$ zameno za spolni odnos. Ovadbe je na

\footnotetext{
${ }^{33}$ Kazenski zakonik (KZ-1), Uradni list RS, št. 55/08 z novelami do KZ-1E, Uradni list RS, št. 27/17.

${ }^{34}$ Kritično o takšnem načinu medijskega poročanja tudi (Ivanjko, 2015: 3). V zvezi s tem glej tudi (Šošić, 2015), v celoti.

${ }^{35}$ In ne interes novinarjev in medijev, ki zasledujejo čim večjo branost in prodajo - četudi novice prizadenejo posameznike in gospodarske družbe in četudi se kasneje izkaže, da ni bilo nikakršnega kaznivega dejanja.

${ }^{36} \mathrm{~V}$ tej zgodbi sicer nastopa župan in mestna občina Ljubljana, povsem enako pa bi v zgodbi lahko nastopal tudi predsednik uprave ali direktor in gospodarska družba.
} 
podlagi Zakona o dostopu do informacij javnega značaja (ZDIJZ) ${ }^{37}$ medijem (in s tem javnosti) posredovalo državno tožilstvo, ki je ocenilo, da razkritje teh ovadb ne škoduje interesom kazenskega postopka. Pri čemer pa je tako ravnanje državnega tožilstva odobril tudi Informacijski pooblaščenec.

Po preučitvi trenutne slovenska zakonodaja (predvsem Zakon o kazenskem postopku (ZKP) 38 in ZDIJZ) smo ugotovili, da ta omogoča najhujše posege $\mathrm{v}$ posameznikovo dostojanstvo, dobro ime in zasebnost, javno linčanje in uničene dobrega imena že na podlagi najnižjega dokaznega standarda (razlogi za sum) in brez kakršnihkoli resnih omejitev. Z drugimi besedami - grobost in intenziteta posega $\mathrm{v}$ posameznikovo dostojanstvo, zasebnost in dobro ime, ter na drugi strani utemeljenost tega posega, ki ga more država izkazati (dokazni standard v kazenskem postopku $\mathrm{v}$ navezi $\mathrm{z}$ javnim interesom po seznanitvi s podatki), je tako očitno nesorazmerna, da slovenska zakonodaja s tega vidika nikakor ne more prestati temeljnega testa ustavnosti. To pa predvsem na račun tega, da aktualna zakonodaja povsem zanemarja dejstvo, da se pri vprašanju medijskega poročanja o kazenskih postopkih soočajo trije ustavni interesi - posameznikovo dostojanstvo, njegovo dobro ime (dobro ime gospodarske družbe) in zasebnost na eni strani, interes javnosti, da se seznani s kazenskimi postopki in delovanjem organov pregona na drugi, in pravičnost kazenskega postopka na tretji.

Veljavna zakonodaja po ZDIJZ glede medijskega poročanja o kazenskih postopkih tega odnosa ne vzpostavi in upošteva le in samo en kriterij - ali bi razkritje informacij škodilo kazenskemu postopku -, je zato neustavna, saj posameznikovega dostojanstva, dobrega imena (dobrega imena gospodarske družbe) in zasebnosti $\mathrm{v}$ predkazenskem postopku in predhodnem kazenskem postopku sploh ne upošteva, obenem pa povsem zanemarja ustaljeno kazenskopravno doktrinarno stališče, da ste te dve fazi postopka tajni, oziroma $\mathrm{da}$ organi pregona medijem $\mathrm{v}$ tej fazi ne sporočajo informacij o pregonu kaznivega dejanja.

\footnotetext{
37 Zakon o dostopu do informacij javnega značaja (ZDIJZ), Uradni list RS, št. 24/03 z novelami do ZDIJZ-F, Uradni list RS, št. $7 / 18$.

${ }^{38}$ Zakon o kazenskem postopku (ZKP), Uradni list RS, št. 63/94 z novelami do ZKP-M, Uradni list RS, št. $87 / 14$.
} 
Pri tem pa opozarjamo, da to ne pomeni, da mediji ne smejo poročati o potencialnih kaznivih dejanjih, ki jih sami zaznajo ali jih zaznajo njihovi viri torej tudi ko kazenski postopek še ne teče. To bi namreč pomenilo nedopustno omejitev svobode govora po 10. členu Evropske konvencije o človekovih pravicah. Pomeni le, da državni organi svojih informacij niso dolžni posredovati medijem, torej morajo ohranijo kot tajno vse, kar preučujejo znotraj predkazenskega postopka - torej gre za omejitev posredovanja informacij javnega značaja, ki je upravičena takrat, ko država ni zbrala dovolj dokazov in dovolj tehtno utemeljila suma, da je določena oseba morebiti zares izvršila določeno kaznivo dejanje. Ker je ta sum v zadostni meri utemeljen na glavni obravnavi (dokazni standard za vložitev obtožnice ali obtožnega predloga je namreč utemeljeni sum), seveda nikakor ni sporno, da je glavna obravnava javna in da se o sojenju na glavni obravnavi lahko medijsko poroča $v$ okviru profesionalnih etičnih standardov.

\section{$7 \quad$ Sklep}

Udeleženci okrogle mize so bili enotni, da je odnos medijev do podjetništva pomemben zaradi občutljivosti podjetništva kot tekmovalne igre na prostem trgu. Negativna (še zlasti neresnična, lahko pa že samo sporna) insinuacija lahko uniči poslovanje podjetja in omogoči drugim udeležencem nepravično pridobljeno prednost. Razlogi za poročanje javnosti o domnevnih napakah poslovodstva določenega podjetja so lahko tudi zlonamerni dogovori v korist konkurence iz različnih razlogov. Vzrok za objavo določenih informacij je lahko tudi plačilo, ki ga dobi novinar oziroma medij. Pri tem pa je lahko bistveno večja škoda, ki zaradi takšnega poročanja nastane za določeno podjetje. Mediji se velikokrat ne zavedajo, da opravljajo vlogo nogometnega sodnika, zoper katerega ni možen prav nikakršen ugovor. Majhna napaka pri poslovanju se lahko v medijih prikaže na različne načine in ima lahko za posledico ne samo materialno škodo podjetje, temveč se z neznosno lahkotnostjo diskreditira tudi dostojanstvo človeka, ki je bodisi v vlogi člana poslovodstva ali pa lastnika. Ob tem je zanimivo tudi to, da so mediji a priori bolj negativno razpoloženi do lastnikov kot do članov poslovodstva, ki niso lastniki. To je tipična miselnost iz socializma, katera bo še veliko časa ostala prisotna $\mathrm{v}$ naši sredini. 


\section{Literatura}

Bavcon L., Šelih A., Korošec D. Ambrož M. \& Filipčič K. (2013) Kazensko pravo: splošni del (Ljubljana: Uradni list Republike Slovenije).

Čeferin, R. (2013) Meje svobode tiska: Analiza sodne prakese Ustavnega sodiš́a Republike Slovenije in Evropskega sodišča za clovekove pravice (Ljubljana: GV založba).

Day, A. L. (2005) Ethics in Media Communications: Cases and Controversies, 5th ed. (Southbank, Victoria, Australia; Belmont, CA: Wadsworth Publishing).

Dežman Z. \& Erbežnik A. (2003) Kažensko procesno pravo Republike Slovenije (Ljubljana: GV založba).

Gavranović, A. (2017) Dominantan medijski nibilizam, dostopno na: https://www.hnd.hr/dominantan-medijski-nihilizam (December 5, 2017).

Ivanjko, S. (1997) Moralno varstvo in medijsko sojenje (novinarka etika), Podjetje in delo, 23(6-7), str. 1177-1195.

Ivanjko, Š. (2014) Sporno napovedovanje obsodbe na televizijskih poročilih, Pravna prakesa, 33(13), str. 3.

Kunczik, M. \& Zipfel, A. (2006) Uvod u znanost o medijima i komunikologiju (Zagreb: Zaklada Friedrich Ebert), dostopno na: http://www.fes-croatia.org/old-site/Ebooks/pdf/ (Februar 5, 2019).

Pirc Musar, N. \& Kraigher Mišič, T. (2017) Zakon o dostopu do informacij javnega značaja (ZDIJZ): (neuradno prečišceno besedilo): s komentarjem (Ljubljana: Uradni list Republike Slovenije).

Pohar, M. (2018) Kako se spopasti z lažnimi novicami?, Pravna praksa, 37(10), str. 6-8.

Steinbuch, D. (2019) Sedem let kasneje: Moji spomini na Danila Slivnika (1950-2012), dostopno na: https://www.portalplus.si/3034/danilo-slivnik-1950-2012 (Januar 4, 2019).

Škarja, P. (2013) Hudiček $v$ podjetniški duši, dostopno na: https://www.petraskarja.com/hudicek-v-podjetniski-dusi/ (April 3, 2013).

Šošić, M. (2015) Varstvo osebnostnih pravic obdolžencev pri medijskem poročanju o kazenskih postopkih, Pravnik, 70(3/4), str. 233-257.

Teršek, A. (2007) Svoboda ižražanja v sodni praksi Evropskega sodǐ̌s̆a za človekove pravice in slovenski ustavnosodni praksi (Ljubljana: Informacijsko dokumentacijski center Sveta Evrope pri NUK).

Teršek, A. (2018) Kaj je ostalo od filozofije in teorije svobode izražanja v postfaktični družbi - laganje oblastnega menedžerstva in institucionalizacija laži?, V: Teršek, A. Svoboda Izražanja, mediji in demokracija v postfakticni družbi: filozofske, teoreticne in praktične refleksije, (Ljubljana: Lexpera, GV založba), str. 15-26.

Tomažič, L. M. (2018) Boj proti lažnim novicam kot napad na demokratične vrednote, Pravna praksa, 37(3/4), str. 17-18.

Veselič, P. (2019) Dr. Jure Knez, Dewesoft: Slovenska drǔ̌ba pri odnosu do podjetnikov stopa v kameno dobo (1. del intervjuja), dostopno na: https://www.domovina.je/dr-jureknez-dewesoft-slovenska-druzba-pri-odnosu-do-podjetnikov-stopa-v-kamenodobo-1-del-intervjuja/ (Januar 4, 2019).

Završnik A. (2018) Lažne novice in razpad realnosti, Pravna praksa, 37(15), str. 23. 


\title{
Dopustnost medijskega poročanja v predkazenskem in predhodnem kazenskem postopku
}

\author{
MIHA ŠEPEC
}

Povzetek V prispevku analiziram zakonsko ureditev dopustnosti medijskega poročanja $\mathrm{v}$ predkazenskem in predhodnem kazenskem postopku. Glavne obravnave v kazenskih postopkih so javne, dilema pa nastane $\mathrm{v}$ kolikšni meri je javen tudi predkazenski postopek in faza preiskave? Zakon o kazenskem postopku tega vprašanja ne ureja, medtem ko kazenskopravna teorija zavzema stališče naj bi bil tako predkazenski kot predhodni kazenski postopek tajen. Tega stališče ne deli Zakon o dostopu do informacij javnega značaja, ki smatra vse informacije državnih organov $v$ kazenskem postopku za informacije javnega značaja, pri čemer dopušča izjemo, da organi pregona zavrnejo dostop do takih informacij, če bi to škodovalo kazenskemu pregonu, pri čemer pa povsem zanemari dostojanstvo, dobro ime in zasebnost posameznikov, ki so subjekti predkazenskega in predhodnega postopka, zaradi česar so po mojem mnenju določbe tega zakona, ki urejajo javnost informacij zbranih $\mathrm{v}$ predkazenskem postopku, neustavne.

Ključne besede: - Medijsko poročanje - Kazenski postopek • Informacija javnega značaja - Zakon o dostopu do informacij javnega značaja $\bullet$ Kazenska ovadba •

NASLOV AVTORJA: Miha Šepec, Univerza v Mariboru, Pravna fakulteta, Maribor, Slovenija, e-pošta: miha.sepec@um.si. 


\title{
Media Reporting in Pre-trial and Preliminary Criminal Procedures
}

\author{
MIHA ŠEPEC
}

\begin{abstract}
In the paper, I analyse the regulation on media reporting in pre-trial and preliminary criminal proceedings. The main trial in the criminal procedure is public, therefore the dilemma is how public is the pre-trial procedure or the criminal investigation. The Criminal Procedure Act does not regulate this issue, while the criminal law theory takes the view that all phases before the trial should be conducted in secret (this however does not limit the press to report on their own findings, it only limits the law enforcement authorities on reporting their findings to the press). This position is not shared by the Act on Access to Public Information which considers all information of enforcement authorities - including in criminal proceedings - as information of public character. The latter act allows an exception that the law enforcement authorities may refuse access to such information, if this would harm the criminal procedure, while completely neglecting the dignity, goodwill and privacy of individuals who are subjects of pre-trial and preliminary criminal proceedings, which, in my opinion, makes it unconstitutional.
\end{abstract}

Keywords: $\bullet$ Media reporting $\bullet$ Criminal proceedure $\bullet$ Information of public interest $\bullet$ Act on access to information of public interest - Criminal charge •

CoRreSPONDENCE AdDRESS: Miha Šepec, University of Maribor, Faculty of Law, Maribor, Slovenia, e-mail: miha.sepec@um.si. 


\section{$1 \quad$ Uvod}

Mediji nam kot psi čuvaji demokracije vsakodnevno poročajo o dogodkih v svetu. S svojim poročanjem skrbijo, da smo prebivalci seznanjeni z novicami, političnimi odločitvami oblasti in pomembnimi dogodki $\mathrm{v}$ državi in svetu. Pomemben del medijskega poročanja je tudi obveščanje javnosti o kazenskih postopkih, s čimer mediji omogočajo posredno nadziranje delovanja sodne oblasti s strani ljudstva. Glavne obravnave so javne, tako da jim lahko vsakdo prisostvuje (z izjemo kadar je javnost izključena). A ker ljudje nimamo časa, da bi dneve preživljali na sodiščih, to za nas počno novinarji, ki nas obveščajo kaj se dogaja v sodnih dvoranah. Pri poročanju o kazenski zadevi mora novinar držati visoko raven profesionalnosti in pri tem (glede na naravo postopka omejeno) varovati tako zasebnost in dostojanstvo posameznika, kot domnevo nedolžnosti, ki je $z$ vidika medijskega poročanja absolutna in jo mora novinar varovati brez omejitev, kar določa tudi 18. točka Kodeksa Društva novinarjev Slovenije. ${ }^{1}$ Novinarsko poročanje o kazenski zadevi se torej ne sme sprevreči v medijsko sojenje, pri katerem bi novinar podal svojo medijsko sodbo v zadevi (da je nekdo storil določeno kaznivo dejanje, četudi sodišče še ni podalo pravnomočne obsodilne sodbe, ali da je obdolženec zagotovo nedolžen). Naloga novinarja ni, da poda svoje stališče o krivdi obdolženca $v$ kazenskem postopku, temveč je zaradi narave predmeta sojenja in zaradi spoštovanja domneve nedolžnosti, omejen na poročanje o dejstvih in dogodkih v sodni dvorani. Četudi se novinar loti komentiranja dela sodišča (kot na primer v zadevi Sunday Times v. Združeno $K_{\text {raljestvo }}^{2}$ ), pa se njegovi komentarji $\mathrm{v}$ kazenskem postopku, ravno zaradi varstva domneve nedolžnosti, ne smejo nanašati na krivdo ali nedolžnost obdolženca v postopku. Ob tem velja opozoriti, da je varovanje avtoritete in nepristranskosti sodstva tudi ena izmed omejitev svobode govora, ki jo določa 10. člen Evropske konvencije o človekovih pravicah. Ko torej govorimo o dopustnem obsegu medijskega poročanja $\mathrm{v}$ kazenskih zadevah je prva dilema o čem in na kakšen način novinar sploh lahko poroča in piše o kazenskih zadevah.

\footnotetext{
${ }^{1} \mathrm{Z}$ besedilom: Ko novinar poroča s področja pravosodja, upošteva, da nihče ni kriv, dokler ni pravnomočno obsojen. Novinar mora biti pazljiv pri omembi imen in objavi fotografij in posnetkov storilcev, žrtev in njihovih svojcev v poročilih o nesrečah in predkazenskih postopkih. Društvo novinarjev Slovenije, sprejet 10. oktobra 2002, Izola.

${ }^{2}$ Evropsko sodišče za človekove pravice (1979), št. 6538/74.
} 
Druga ključna dilema poročanja $\mathrm{v}$ kazenskih postopkih, ki je tako $\mathrm{v}$ teoriji kot praksi še bolj zamegljena, pa je, kdaj mediji dejansko lahko začno poročati o samem kazenskem postopku? Že v fazi, ko neko zadevo, ki bi lahko bila kaznivo dejanje, preučuje policija? Ali morda ko se uvede faza preiskave, kjer je določena oseba že osumljena določenega kaznivega dejanja? Ali morda šele ko državni tožilec vloži obtožnico in ta postane pravnomočna, kar pomeni, da bo kazenska zadeva dobila svoj epilog v sodni dvorani na glavni obravnavi?

Ta vprašanja so ključna tako za delo novinarjev, kot za delo organov pregona, saj mora biti jasno določena meja, kdaj lahko organi pregona novinarjem predajo informacije o vodenju kazenske zadeve, in kdaj morajo določene podatke in informacije o vodenju kazenskega postopka ohraniti kot tajne.

Glede prve dileme v slovenskem pravnem prostoru že imamo kvalitetno znanstveno analizo (Šošić, 2015), zato se bom sam v prispevku ukvarjal pretežno $z$ drugo dilemo.

Povod za pisanje tega prispevka, ki obenem predstavlja podlago za podrobno analizo slovenske zakonodaje in prakse na tem področju, je primer ljubljanskega župana Zorana Jankovića, katerega je policija (Nacionalni preiskovalni urad) preiskovala glede številnih kaznivih dejanj. V avgustu leta 2017 je spletni portal Pod črto pridobil kopije kazenskih ovadb, ki jih je zoper njega pripravil Nacionalni preiskovalni urad. V ovadbah je Janković osumljen pranja denarja in preslepitve bank $\mathrm{v}$ zadevi Stožice, utaje davkov pri prodaji delnic Mercatorja in posredovanja pri zaposlitvi farmacevtke $\mathrm{v}$ stiski $\mathbf{v}$ zameno za spolni odnos. Ovadbe je na podlagi Zakona o dostopu do informacij javnega značaja (ZDIJZ) ${ }^{3}$ medijem (in s tem javnosti) posredovalo državno tožilstvo, ki je ocenilo, da razkritje teh ovadb ne škoduje interesom kazenskega postopka. Pri čemer pa je tako ravnanje državnega tožilstva odobril tudi Informaciji pooblaščenec.

\footnotetext{
${ }^{3}$ Zakon o dostopu do informacij javnega značaja (ZDIJZ), Uradni list RS, št. 24/03 z novelami do ZDIJZ-F, Uradni list RS, št. 7/18.
} 
Na podlagi poglobljene analize bom prikazal, da trenutna slovenska zakonodaja (predvsem Zakon o kazenskem postopku (ZKP) 4 in ZDIJZ) omogoča najhujše posege $v$ posameznikovo dostojanstvo, dobro ime in zasebnost, javno linčanje in uničene dobrega imena že na podlagi najnižjega dokaznega standarda (razlogi za sum) in brez kakršnihkoli resnih omejitev. Z drugimi besedami - grobost in inteziteta posega $\mathrm{v}$ posameznikovo dostojanstvo, zasebnost in dobro ime, ter na drugi strani utemeljenost tega posega, ki ga more država izkazati (dokazni standard $\mathrm{v}$ kazenskem postopku $\mathrm{v}$ navezi z javnim interesom po seznanitvi s podatki), je tako očitno nesorazmerna, da slovenska zakonodaja s tega vidika nikakor ne more prestati temeljnega testa ustavnosti.

\section{Dopustnost medijskega poročanja $v$ predkazenskem in predhodnem kazenskem postopku}

\subsection{Zasebnost, dostojanstvo, svoboda govora, poštenost kazenskega postopka}

Ko mediji ${ }^{5}$ poročajo o kazenskem postopku se pri tem navzkrižno soočijo trije pravni interesi. Na eni strani imamo posameznika, ki je predmet kazenskega postopka. Država ga je obtožila določenega kaznivega dejanja, zdaj pa mu sodi, da bi se ugotovila njegova krivda ali nedolžnost. Posameznikov interes je ohranitev njegove zasebnosti in dobrega imena, ki sta skupaj zajeti v njegovi pravici do dostojanstva, tako $\mathrm{v}$ primeru obsodilne sodbe, še toliko bolj pa $\mathrm{v}$ primeru oprostilne sodbe ali ustavitve postopka.

Na drugi strani se postavlja svoboda govora oziroma svoboda izražanja, ki zajema tako pravico do podajanja informacij, kot pravico do prejemanja informacij. $\mathrm{V}$ svojem bistvu zajema pravico javnosti, da je seznanjena z dogodki na sodišču, pri čemer velja pravilo, da hujše kot je bilo dejanje, bolj kot je oseba medijsko izpostavljena (absolutno javna oseba, relativno javna oseba), večji je javni interes po razkritju informacij o kazenskem postopku.

\footnotetext{
${ }^{4}$ Zakon o kazenskem postopku (ZKP), Uradni list RS, št. 63/94 z novelami do ZKP-M, Uradni list RS, št. $87 / 14$.

${ }^{5}$ Skladno s prvim odstavkom drugega člena Zakona o medijih (ZMed) so mediji časopisi in revije, radijski in televizijski programi, elektronske publikacije, teletekst ter druge oblike dnevnega ali periodičnega objavljanja uredniško oblikovanih programskih vsebin s prenosom zapisa, glasu, zvoka ali slike, na način, ki je dostopen javnosti.
} 
Kot tretji interes je na tehnici interes pravičnosti kazenskega postopka. Le pravičen kazenski postopek, ki zajema tudi pravico do poštenega obravnavanja, lahko privede do pravno sprejemljive sodne odločbe. Če mediji okužijo javnost z neprofesionalnim pristranskim poročanjem o kazenski zadevi, ima to lahko velik vpliv tudi na izzid kazenskega postopka. Država ima pozitivno dolžnost varovati domnevo nedolžnosti obdolženca in s tem njegovo pravico do poštenega obravnavanja, vse dokler ta ni pravnomočno obsojen. V interesu poštenega postopka (fair trial po 6. členu Evropske konvencije o varstvu človekovih pravic in temeljnih svoboščin - EKČP) mora zato država preprečiti medijsko sojenje, ki poteka $\mathrm{v}$ medijih izven sodnih prostorov in kjer te sodbe podajajo novinarji in javnost, ki niso profesionalni sodniki. Obenem ima država tudi "pozitivno dolžnost, da v zuezi s poročanjem o kazenskih zadevah zagotovi varstvo osebnostnih pravic obdoľ̌encevv, zlasti njihove pravice do lastne podobe« (Šošić, 2015: 238).

Pravica do zasebnosti je z Ustavo RS (35. člen) in EKČP (8. člen) varovana temeljna človekova pravica, ki zagotavlja vsakomur, da tako država, kot drugi posamezniki ne posegajo $\mathrm{v}$ njegovo zasebno življenje.

Zasebnost velja za temeljno ustavno in mednarodno zavarovano vrednoto. Mednarodni pakt o državljanskih in političnih pravicah jo varuje v 17. členu, Evropska konvencija o človekovih pravicah (EKČP) v 8. členu, slovenska Ustava pa v členih 35, 36, 37 in 38. Ustavno sodišče je v odločbi Up 32/946 zapisalo: "Cllovekova zasebnost, katere nedotakljivost ragotavlja 35. člen Ustave, je v obmor̆ju clovekovega bivanja bolj ali manj sklenjena celota njegovih ravnanj in ukvarjanj, obcutij in

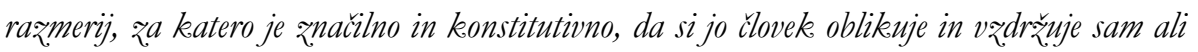
sam z najbližjimi, s katerimi je v intimni skupnosti, na primer z zivljenjskim partnerjem, in da v njej biva z.obiutkom varnosti pred vdorom javnosti ali kogarkoli nezaželenega."

Slovenska Ustava varuje zasebnost v štirih členih. Člen 35 (Varstvo pravic zasebnosti in osebnostnih pravic) varuje splošno zasebnost posameznika, 36. člen (Nedotakljivost stanovanja), 37. člen (Varstvo tajnosti pisem in drugih občil) ter 38. člen (Varstvo osebnih podatkov) pa varujejo vsak specifičen aspekt zasebnosti (zasebnost prostorov, komunikacije in posameznikovih podatkov). Čebulj opredeli tri sestavine zasebnosti: zasebnost $\mathrm{v}$ prostoru (možnost posameznika, da se ga pusti na miru tam, kjer živi), zasebnost osebnosti (svoboda misli, izražanja in opredelitve) ter informacijska zasebnost (pravica posameznika,

${ }^{6}$ Ustavno sodišče (1995), odločba Up 32/94. 
da obdrži podatke o sebi zasebne in da se v njih ne posega) (Čebulj, 1992: 7). Vsekakor bi bilo tej razdelitvi potrebno dodati še komunikacijski vidik zasebnosti kot samostojen aspekt splošne pravice do zasebnosti. Toplak nas opozarja na dualistični koncept pravice do zasebnosti. Ta se namreč pojavlja v dveh oblikah: kot osebnostna pravica (zasebnega značaja) in kot človekova pravica (javnopravnega značaja) (L. Toplak v Šturm, 2002: 369). Zasebnost je torej ustavna pravica, ki varuje posameznika tako pred posegi države kot pred posegi drugih posameznikov.

Zasebnosti ne moremo pojmovati le kot strogo pasivno pravico neposeganja $\mathrm{v}$ posameznikovo osebnostno sfero - torej kot izločanje posameznika iz družbe. Ravno nasprotno, demokratičnost družbe se kaže ravno v tem, kako je zasebnost varovana, ko je posameznik v interakciji z družbo. To seveda ne pomeni, da se zasebnost varuje, ko posameznik javno oznanja informacije o sebi - zasebnost je namreč tipična disponibilna pravica in se ji posameznik lahko odreče. Zasebnost mora biti varovana takrat, ko jo posameznik upravičeno pričakuje skladno s konceptom pričakovanja zasebnosti (reasonable expectation of privacy), ki ga je vzpostavilo Vrhovno sodišč ZDA v zadevi Katz proti ZDA, prevzelo pa tudi Evropsko sodišče za človekove pravice (ESČP) v zadevi Halford proti Združeno kraljestvo $^{7}$ in slovensko Ustavno sodišče. Po tem konceptu se presoja posameznikovo pričakovanje zasebnosti in upravičenost tega pričakovanja. Kot zapiše Vrhovno sodišče ZDA v primeru Katz: »Kar oseba vede iə̧postavi javnosti, pa ceprav na svojem domu ali v pisarni, ni predmet varstva (po konceptu pričakovanja zasebnosti, op. avtorja). Kar pa skuša obraniti kot zasebno, ceprav na javnosti dostopnem mestu, pa je labko predmet ustavnega varstva." (Katz v. Združene države Amerike v (Zupančič, 2000: 339, 340)). Kot zapiše sodnik Harlan v pritrdilnem ločenem mnenju v zadevi Katz proti ZDA: »Obstaja tu dvojni kriterij; prvič, da je oseba iærazila dejansko (subjektivno) pričakovanje zasebnosti, in drugič, da je pričakovanje takšsno, da ga je družba pripravljena sprejeti kot upravičeno.« (Katz v. Združene države Amerike v (Zupančič, 2000: 342, 343).

Klemenčič kot ključno maksimo ustavnega varovanja zasebnosti opredeli: »Pravo (Ustava) ne šíti zgolj prostorov, lastnine ali lastnikov, temveč posameznike, ki v določenem trenutku, $v$ določenem prostoru ali pri določenem ravnanju (upravičeno) pričakujejo svojo zasebnost.« (G. Klemenčič v Šturm, 2002: 401). Pravica do zasebnosti tako vključuje tudi možnost posameznika, da je $\mathrm{v}$ interakciji z družbo. To je nazorno

${ }^{7}$ Evropsko sodišče za človekove pravice (1997), št. 20605/92. 
obrazložilo ESČP v primeru Niemitz proti Nemčija. ${ }^{8}$ Sodišče meni, da bi bila popolna izključitev zunanjega sveta preveč restriktivna. Spoštovanje zasebnega življenja mora obsegati do določene mere tudi pravico do navezovanja in razvijanja odnosov z drugimi (M. Orehar Ivanc v Šturm, 2002: 372). Še pred tem je tako stališče zavzelo Vrhovno sodišče ZDA leta $1891 \mathrm{v}$ zadevi Union Pacific Railway proti Botsford, o kateri je zapisalo: »Pravica do zasebnosti je v veliki meri pomembna vrednota prav zato, ker pospešuje izmenjavo informacij z drugimi ljudmi, ustvarjanje in utrjevanje dru乏̌benih vezi in ne zgolj zaradi zagotavljanja neodvisnosti in izolacije od drugib. «?

Tudi slovensko Ustavno sodišče je sledilo enaki razlagi. V odločbi Up-50/9910 je zapisalo, da »bi področje zasebnega življenja labko razdelili: na podroc̆je intimnega in drǔ̌inskega ̌̌ivljenja, ki se ne odvija v javnosti, in na področje življenja posameznika v javnosti.« Ob tem pa je sodišče opozorilo, da čim manj je intimno področje zasebnega življenja posameznika, tem manjšo pravno zaščito ima.

Poleg zasebnosti pa ima posameznik tudi pravico do dobrega imena, ki skupaj z zasebnostjo spadata $\mathrm{v}$ njegovo pravico do dostojanstva, ki jo naša Ustava varuje v 34. členu. Človekovo dostojanstvo je na eni strani splošna in temeljna pravica, na katerih temeljijo vse ostale človekove pravice - je torej nekakšna nadpravica, ki ni konkretizirana in povezuje vse ostale človekove pravice. Na drugi strani pa je obenem tudi konkretizirana specialna človekova pravica, ki jo kot tako določa 34. člen Ustave RS. Nemška pravna teorija pravico do dostojanstva razume kot splošno osebnostno pravico. V primeru Eppler iz leta 1980 je nemško Ustavno sodišče dostojanstvo razdelilo $\mathrm{v}$ osem pravno zavarovanih poddobrin posameznika: njegova intimna sfera, zasebna sfera, tajna sfera, osebna čast, razpolagalna pravica predstavitve lastne osebe, pravica do lastne podobe, pravica do izrečene besede in pravica biti prost pred podtaknjenimi izjavami (Lampe, 2010: 176).

Bloustein razlaga, da je kršitev pravice do zasebnosti dejansko kršitev človekovega dostojanstva. Napad na zasebnost je torej obenem napad na posameznikovo dostojanstvo (Bloustein, 1964: 962-1007), slednje pa je prav tako lahko prizadeto tudi takrat, ko posameznik ne uživa zasebnosti, kar je tipično za absolutno javne osebe, ki se znajdejo v kazenskem postopku - četudi te osebe ne

\footnotetext{
${ }^{8}$ Evropsko sodišče za človekove pravice (1992), št. A 251-B.

${ }^{9}$ Vrhovno sodišče ZDA, povzeto po G. Klemenčič v: (Šturm, 2002: 392).

${ }^{10}$ Ustavno sodišče (2000), odločba Up-50/99.
} 
uživajo zasebnosti $\mathrm{v}$ javnosti, mora država še vedno ščititi njihovo osebno dostojanstvo in dobro ime.

Lampe razlaga, da je dostojanstvo podstat drugih človekovih pravic, pri čemer je garant dostojanstva prav pravica do časti in dobrega imena. Slednja je izpeljanka pravice do dostojanstva, ki je prav tako temeljno jamstvo telesne in duševne celovitosti. Pri tem razlikuje notranjo in zunanjo čast posameznika, pri čemer slednja pomeni isto kot ugled oziroma dobro ime, ki ga posameznik uživa $\mathrm{v}$ družbi, oziroma vrednotenje ali priznavanje moralnih in drugih kvalitet posameznika pri drugih (Lampe, 2010: 181).

Z vidika posameznikova dostojanstva in njegove zasebnosti je torej ključno vprašanje do kdaj posameznikovo dostojanstvo in njegova zasebnost kot ustavni pravici prevladata nad pravico javnosti, da se seznani $z$ vmešavanjem države $v$ posameznikovo intimno sfero. To vprašanje bo v celoti povezano s fazo, $\mathrm{v}$ kateri je kazenski postopek in z dokaznim standardom, ki ga država mora izkazati in s tem upravičiti njene posege v posameznikove ustavne pravice. Nesporno je, da posameznik ne more upravičeno pričakovati zasebnosti (lahko pa pričakuje določeno raven spoštovanja njegovega dostojanstva), ko kazenski postopek poteka na glavni obravnavi, saj je slednja javna. Vsakdo lahko prisostvuje glavnim obravnavam in se seznani s kazensko zadevo - enako velja za novinarje, ki lahko te informacije posredujejo javnosti, s čimer slednja posredno nadzira delo sodne oblasti. Bistveno bolj sporno vprašanje pa je ali se ima javnost pravico seznaniti s kazensko zadevo, ko je ta še v fazi predkazenskega postopka ali v fazi preiskave? Te faze niso javne, zato se zdi smiselno, da bi morala država posameznikovo zasebnost in njegovo dostojanstvo (in v tem okviru predvsem njegovo dobro ime) tu bolje ščititi kot interese javnosti, saj v tej fazi javnost še ne vrši nadzora nad sodno oblastjo. O tem več v nadaljevanju.

Svoboda izražanja je z Ustavo RS (39. člen) in z EKČP (10. člen) varovana človekova pravica, ki zajema svobodno manifestiranje misli (svoboda mišljenja freedom of thought) $\mathrm{z}$ govorjeno besedo (svoboda govora - freedom of speech), ki vključuje tako javno nastopanje (svoboda javnega nastopanja - freedom of public appearance), kot tudi pisno besedo (svoboda tiska - freedom of the press) ali celo dejanja, ki izražajo mnenje (simbolični govor - symbolic speech) (Lampe, 2010; 323). 
Funkcija svobode izražanja je prost pretok informacij v družbi, ki omogoča vsakomur, da izrazi svoja stališča in mnenja (če le ta niso v nasprotju s pravnim redom ali ne posegajo $\mathrm{v}$ temeljne pravice drugih), ter nadzor politike in državne oblasti preko javnih medijev, ki opravljajo vlogo "psa čuvaja« in s tem krepijo in omogočajo demokratičnost družbe.

Svoboda izražanja v temelju zajema dve ločeni ključni temeljni pravici - svobodo mišljenja in svobodo sprejemanja in sporočanja obvestil.

Svoboda mišljenja (freedom to hold opinion) zagotavlja posamezniku pravico, da pove, kar mu leži na duši. $\mathrm{V}$ demokratični svobodni družbi lahko vsakdo deli svoja mnenja in stališča z ostalimi, ne da bi ga državna oblast pri tem omejevala. Izjemo od navedenega stališča predstavljajo legitimne omejitve svobode izražanja, ki jih določa 10. člen EKČP in ki jih lahko strnemo na sledeče razloge: zagotavljanje nacionalne varnosti, ozemeljske celovitosti in javne varnosti; preprečevanje neredov ali zločinov; varovanje ugleda ali pravic drugih ljudi; varovanje avtoritete in nepristranskosti sodstva. ${ }^{11}$

Svoboda sprejemanja in sporočanja obvestil oziroma svoboda širjenja in prejemanja informacij (freedom to impart and to receive information and ideas) zagotavlja posamezniku dostop in seznanitev z informacijami, ki zadevajo delovanje družbe. $\mathrm{V}$ okviru te pravice sta najbolj pomembni svoboda tiska (freedom of the press) in svoboda oddajanja (freedom of broadcasting), ki zagotavljata medijem prosto nadziranje družbene oblasti in kritiziranje političnih odločitev, kar je ključno za obstoj demokratične družbe. Kot je zapisalo ESČP v zadevi Lingens v. Avstrija: ${ }^{12}$ "Prvotna funkecija tiska je prenos informacij in idej o političnih zadevah kakor tistih spodroc̆ja javnega interesa. Ne samo, da ima tisk nalogo in pravico prenašati tourstne informacije, tudi javnost ima pravico te informacije prejemati. «13

Z vidika svobode izražanja je ključno, da ima javnost pravico do informiranja da se torej lahko seznani s kazenskimi postopki, ki potekajo v državi. Večji pomen kot ga ima kazenska zadeva za javnost, večji je interes javnosti, da je seznanjena s potekom kazenskega postopka. Ta pravica javnosti nesporno zajema seznanjenost s kaznivim dejanjem, potencialnimi storilci oziroma obdolženci tega kaznivega dejanja, vsaj okvirnim potekom glavne obravnave,

\footnotetext{
${ }^{11}$ Več o omejitvah v (Lampe, 2010: 344-374), prav tako tudi K. Jaklič v (Šturm, 2002: 423-426).

${ }^{12}$ Evropsko sodišče za človekove pravice (1986), št. 9815/82.

${ }^{13}$ Povzeto po (Lampe, 2010: 335).
} 
dokazi, ki pričajo v korist in $\mathrm{v}$ škodo obdolženca in podobno. Zopet pa je ključno vprašanje, kdaj se aktivira pravica javnosti, da se seznani s temi informacijami. Se ta pravica informiranja javnosti o (za javnost pomembnih) kazenskih postopkih nanaša le na fazo glavne obravnave, ali pa se morda razteza tudi v fazo preiskave ali celo predkazenskega postopka, ko država z najnižjim dokaznim standardom operira le s potencialnimi osumljenci kaznivega dejanja?

Odgovora na to vprašanje ni mogoče podati, dokler ne opredelimo še načela pravičnosti in pravice do poštenega sojenja $\mathrm{v}$ kazenskem postopku. Načelo pravičnosti je temeljno vodilo in načelo sodobnega kazenskega postopka. To načelo je izpodrinilo načelo iskanja materialne resnice in danes velja za prevladujoče načelo kazenskega postopka (Dežman \& Erbežnik, 2003: 220). Zajema tudi pravico do poštenega obravnavanja oziroma pravico do poštenega sojenja, ki je varovana v 6. členu EKČP, ki vsebuje tako domnevo nedolžnosti kot zahtevo, da se sodbe morajo izreči javno. Člen 6 EKČP obenem tudi določa, da sta tisk in javnost lahko izločena iz sojenja deloma ali v celoti v interesu morale, javnega reda ali državne varnosti, če to $\mathrm{v}$ demokratični družbi zahtevajo koristi mladoletnikov ali varovanje zasebnega življenja strank, pa tudi tedaj, kadar bi po mnenju sodišča zaradi posebnih okoliščin javnost sojenja škodovala interesom pravičnosti. EKČP nikjer ne omenja, da bi bila javna tudi katerakoli faza pred dejanskim sojenjem - torej pred glavno obravnavo. Je pa praksa ESČP zelo striktna, ko gre za domnevo nedolžnosti. Ta mora biti varovana tako v sodni dvorani, kot izven nje $\mathrm{v}$ medijih. Pristransko poročanje $\mathrm{v}$ medijih namreč lahko vpliva na poštenost samega postopka. Zato EKČP v 6. členu omogoča izključitev javnosti iz sojenja, če je to potrebno, obenem pa v 10. členu varovanje avtoritete in nepristranskosti sodstva postavlja kot eno izmed zakonitih omejitev svobode govora. Nesporno torej je, da država lahko omeji poročanje o kazenskih zadevah, če bi tako poročanje lahko pretirano vplivalo na poštenost sojenja ali na avtoriteto in nepristranskost sodstva. Ponovno pa je treba poudariti, da EKČP omenja le javnost sojenja - in ne javnost celotnega kazenskega postopka! Glede faze predkazenskega postopka in faze preiskave EKČP molči. Sklepanje po nasprotnem razlogovanju (argumentum a contrario) nam daje vtis, da naj bi torej te dve fazi bili tajni. Nasprotni argument pa bi bil, da ko EKČP v naslovu 6. člena govori o »fair trial« dejansko misli celoten kazenski postopek od samega začetka, ko policija začne zbirati dokaze in pridobi osumljenca do zaključka glavne obravnave - ta argument podpira dejstvo, da se številne pravice znotraj 6. člena EKČP dejansko nanašajo na predhodne faze kazenskega postopka (npr. pravica do seznanitve obtožbe v jeziku, ki ga razume; do primernega časa za obrambo; 
do obrambe z zagovornikom; do brezplačne pomoči tolmača itd.). Obenem pa je tudi res, da 6. člen EKČP te pravice veže na tiste, ki so obdolženi kaznivega dejanja (»charged with a criminal offence«), in teh pravic ne povezuje z javnostjo sojenja, kar zoper lahko uporabimo kot protiargument, da se javnost »sojenja« razteza tudi na te predhodne faze. Varno lahko torej trdimo, da se EKČP v to vprašanje ne spušča in da ostaja odprto sodni interpretaciji in analizi kazenskopravne dogmatike, pri čemer pa se trenutna praksa ESČP pretežno nanaša le na javnost glavnih obravnav (Pretto in ostali v. Italija, ${ }^{14}$ Riepan v. Avstrija, ${ }^{15}$ Axen v. Nemčija ${ }^{16}$...).

ESČP pa na drugi strani postavlja zelo jasne meje pri domnevi nedolžnosti. Državni organi ne smejo izreči ničesar kar bi lahko namigovalo na to, da verjamejo, da je neka oseba kriva za določeno kaznivo dejanje, dokler ni izdana pravnomočna obsodba. ${ }^{17}$ To sicer ne preprečuje državnim organom, da bi informirali javnost o kazenskih preiskavah, ki potekajo, vendar pa se od njih zahteva, da so diskretni in zadržani s ciljem, da se ohrani domneva nedolžnosti oseb v preiskavi. Ob tem je ESČP tudi poudarilo, da poštenost postopka lahko krši ne le sodišče, temveč tudi drugi državni organi. ${ }^{18}$

V zadevi Buscemi v. Italija ${ }^{19}$ je ESČP poudarilo, da imajo pravosodni organi upravičenje in dolžnost, da javnost seznanijo s kazenskimi zadevami samo, kadar je to $\mathrm{v}$ prevladujočem interesu javnosti in ne ovira kazenskega postopka (Šošić, 2015: 249).

Ob tem velja tudi opozoriti, da 10. člen EKČP prepoveduje državi, da bi omejevala prejem informacij, ki jih posamezniku želijo posredovati druge osebe. Ne daje pa posameznikom pravice dostopa do informacij v posesti javnih oblasti, prav tako pa ne zajema dolžnosti države, da posamezniku takšne informacije posreduje (Leander v. Švedska ${ }^{20}$ in Gaskin v. Združeno kraljestvo ${ }^{21}$ ). Država torej po 10. členu EKČP nima dolžnosti zbirati in razširjati informacij, z izjemo ko javne oblasti razpolagajo $\mathrm{z}$ dokumenti, ki vsebujejo osebne podatke

\footnotetext{
${ }^{14}$ Evropsko sodišče za človekove pravice (1984), št. 7984/77.

${ }_{15}$ Evropsko sodišče za človekove pravice (2000), št. 35115/97.

${ }^{16}$ Evropsko sodišče za človekove pravice (1984), št. 8273/88.

${ }_{17}$ Borovsky v. Slovaška, Evropsko sodišče za človekove pravice (2009), št. 24528/02.

18 Allenet de Ribemont v. Francija, Evropsko sodišče za človekove pravice (1995), št. 15175/89, Lavents v. Latvija, Evropsko sodišče za človekove pravice (2002), št. 58442/00 in Zollman v. Združeno Kraljestvo, Evropsko sodišče za človekove pravice (2003), št. 62902/00.

${ }^{19}$ Evropsko sodišče za človekove pravice (1999), št. 29569/95.

${ }^{20}$ Evropsko sodišče za človekove pravice (1987), št 9248/81.

${ }^{21}$ Evropsko sodišče za človekove pravice (1999), 10454/83.
} 
posameznika ali informacije, ki imajo lahko neposreden vpliv na življenje in zdravje posameznikov, pri čemer se dostop do takih informacij priznava na podlagi 8. člena EKČP in ne 10. člena EKČP (Prepeluh, 2005: 115).

\subsection{Faze kazenskega postopka in dokazni standardi}

Kazenski postopek poteka skozi več stadijev oziroma faz, pri čemer ima vsaka svoj točno določen pomen in $\mathrm{v}$ kateri se opravljajo točno določena procesna dejanja. Kazenski postopek je sestavljen iz dveh poglavitnih stadijev, in sicer: predhodnega in glavnega postopka. Pri tem se predhodni postopek deli na fazo preiskave in fazo obtoževanja s presojo utemeljenosti obtožnice, glavni postopek pa se deli na fazo priprave in predobravnavnega naroka, glavno obravnavo s sodbo, postopek s pritožbo in na fazo izvršitve sodbe (Dežman \& Erbežnik, 2003: 756).

Pri tem je seveda ključno kdaj se kazenski postopek zoper obdolženca v smislu opravičenosti medijskega poročanja o kazenski zadevi dejansko začne. Kazensko-procesna teorija načeloma smatra, da se kazenski postopek za obdolženca začne že $\mathrm{v}$ fazi policijske preiskave, ko je sum osredotočen na določenega osumljenca in ko policija začne z zbiranjem dokazov, s katerimi gradi primer proti osumljencu. ${ }^{22}$ Po Zupančiču se »kazenski postopek de facto začne tisti trenutek, ko med posameznikom in dř̌avo zaradi suma storitve kaznivega dejanja nastane osredotočenost in pravno iə̌kristalizirano nasprotje interesov. (Zupančič, 1987: 191). Z vidika pravic, ki pripadajo obdolžencu v kazenskem postopku, je to dejansko (neformalni ali de facto) začetek kazenskega postopka. Z vidika obveščanja javnosti pa bo ključen formalni - tako imenovani de iure - začetek kazenskega postopka.

Dežman in Erbežnik zapišeta, da se kazenski postopek začne s sklepom o preiskavi in zato predkazenski postopek ne sodi med faze kazenskega postopka! (Dežman \& Erbežnik, 2003: 756).

22 Podrobneje glej (Gorkič, 2009). 
Skladno z navedenim se kot formalni začetek kazenskega postopka smatra sklep o preiskavi, ki ga izda preiskovalni sodnik na zahtevo upravičenega tožilca, in na podlagi katerega začne teči preiskava. Če je obtožni akt vložen brez opravljane preiskave (neposredna obtožnica), se kazenski postopek začne s tem, ko postane obtožnica pravnomočna. V skrajšanem postopku se kazenski postopek začne z odreditvijo vročitve obtožnega akta obdolžencu (Horvat, 2004: 941). V primeru kaznovalnega naloga pa se kazenski postopek začne $\mathrm{z}$ izdajo sodbe $\mathrm{o}$ kaznovalnem nalogu oziroma njeno vročitvijo obdolžencu. V postopku zoper mladoletnike se kazenski postopek začne s katerimkoli dejanjem sodnika za mladoletnike (Dežman \& Erbežnik, 2003: 761).

Tudi Ustavno sodišče RS šteje, da se kazenski postopek začne z izdajo sklepa o uvedbi preiskave. ${ }^{23}$

Predkazenski postopek se po drugi strani začne $\mathrm{z}$ aktivnostmi policije (zakonsko določena pooblastila po prvem odstavku 148. člena ZKP), ki imajo namen odkriti kaznivo dejanje ali domnevnega storilca in se konča z začetkom preiskave (prvi odstavek 167. člena ZKP) oziroma zgoraj opredeljenim formalnim začetkom kazenskega postopka.

Termin kazenski pregon ${ }^{24} \mathrm{v}$ teoriji ni teoretično razdelan, sicer pa pomeni vsako dejanje državnega organa, ki je pooblaščen za pregon, in ki je usmerjeno $\mathrm{v}$ preiskovanje domnevnega kaznivega dejanja ali domnevnega storilca kaznivega dejanja. Kazenski pregon torej sovpada z dejansko neformalnim začetkom kazenskega postopka. V našem kazenskem postopku je za kazenski pregon zadolžen državni tožilec.

$\mathrm{Na}$ faze kazenskega postopka se navezujejo tudi dokazni standardi, ki so mejniki posameznih faz kazenskega postopka in ki nam povedo s kakšno stopnjo verjetnosti je država (državno tožilstvo, policija) prepričana, da je določena oseba storila določeno kaznivo dejanje. Dokazni standardi se povezujejo z dokaznimi bremeni, saj mora tisti, ki dokazuje, da opraviči svoj poseg, z določeno stopnjo verjetnosti dokazati, da je podan zadosti visok dokazni standard za odreditev določenega ukrepa (Šugman Stubbs \& Gorkič, 2009: 102). Pri tem je ključni pomen dokaznih standardov ravno to, da utemeljujejo posege v posameznikove

\footnotetext{
23 Odločba Ustavnega sodišča, Up-270/98 z dne 15. 2. 2002.

${ }^{24} \mathrm{Ta}$ termin je pomemben zato, ker ZDIJZ uporablja v 6. členu, kjer določa izjeme od dostopa do informacij javnega značaja.
} 
pravice, še pred izrekom pravnomočne obsodilne sodbe. Posegi v posameznikove pravice in njegovo osebno integriteto so lahko pravno utemeljeni le in samo, če so podkrepljeni s sorazmerno visokim dokaznim standardom, ki upravičuje ukrepe države zoper posameznika. Drugačna ureditev bi namreč dopuščala samovoljo organov pregona. »Izhodišče vsakega procesnega sistema bi morala biti logika, da dř̌ava upravičeno posežev v integriteto posameznika samo takrat, ko obstaja določna stopnja verjetnosti, da je ta oseba prekršila temelina pravila sobivanja. Veřja je verjetnost, da je neka oseba storila kaznivo dejanje, bolj labko posežemo v njeno integriteto.« (Šugman Stubbs \& Gorkič, 2009: 102)

Ta logika mora veljati tudi pri presoji kdaj lahko državni organi medijem posredujejo informacije o kazenskem postopku. Poročanje medijev namreč zagotovo poseže $\mathrm{v}$ posameznikovo integriteto, dostojanstvo, dobro ime in zasebnost. Zato mora država opravičiti tolikšen poseg - torej mora kazenski postopek biti vsaj na določeni meri utemeljen, preden se o njem lahko poroča $\mathrm{v}$ javnosti.

ZKP pozna štiri dokazne standarde: razlogi za sum, utemeljeni razlogi za sum, utemeljen sum, prepričanje, poleg njih pa še nekakšen siu generis dokazni standard »če je mogoče utemeljeno sklepati« in ukrepe za katere zadostujejo že verjetnost - torej manj kot razlogi za sum.

Razlogi za sum so najnižji dokazni standard, kjer zadostuje že minimalna stopnja verjetnosti, ki kaže na to, da je bilo storjeno kaznivo dejanje. Zadostuje že minimalno obvestilo (npr. anonimni klic ali anonimno elektronsko sporočilo) (Šugman Stubbs \& Gorkič, 2009: 104). Ta standard je značilen predvsem za ukrepe policije v predkazenskem postopku, kjer še ni osredotočenosti preiskave. Ko se preiskava osredotoči zoper konkretno osebo in glede konkretnega kaznivega dejanja, je s tem povezan tudi višji dokazni standard utemeljenih razlogov za sum, kjer se praviloma vmeša tudi sodna veja oblasti, ki nadzira zakonitost preiskovalnih ukrepov zoper posameznika. Utemeljeni razlogi za sum je dokazni standard za večino prikritih preiskovalni ukrepov, hišno in osebno preiskavo ...

Utemeljen sum je tisti dokazni standard, s katerim se začne faza preiskave. Ko je podan ta dokazni standard se preiskovanje kaznivega dejanja prenese od policije na sodno vejo oblasti. Za ta dokazni standard načeloma velja, da naj bi izražal vsaj polovično verjetnost, da je določena oseba storila določeno kaznivo dejanje 
(Šugman Stubbs \& Gorkič, 2009: 108). Ta dokazni standard v našem kazenskem postopku obenem služi za odreditev pripora in potrditev obtožnice, kar pomeni da dosega relativno visoko verjetnost prepričanja, da je oseba $v$ kazenskem postopku dejanski storilec kaznivega dejanja. Utemeljen sum mora biti artikuliran, specifičen, konkreten in predhoden.

Zadnji dokazni standard prepričanosti se zahteva za izdajo obsodilne sodbe (drugi odstavek 3. člena ZKP).

Ne more biti sporno, da je dokazni standard ključni element pri presoji, kdaj državni organi lahko medijem posredujejo informacije o kazenskih postopkih. Medijsko poročanje bo namreč, ne glede na sam izzid kazenskega postopka, hudo poseglo v posameznikovo pravico do dostojanstva, zasebnosti in njegovo dobro ime. Tak poseg v posameznikovo dostojanstvo, dobro ime in zasebnost mora torej biti opravičen na temelju dovolj visokega dokaznega standarda. Oziroma z drugimi besedami, če organi pregona zoper posameznika nimajo praktično nič, le nekaj špekulirajo, da bi nekdo morebiti lahko nekaj storil, teh svojih sumničenj ne smejo deliti $z$ mediji, saj bi s tem hudo prizadeli posameznikovo osebno integriteto, za ta poseg $\mathrm{v}$ njegovo integriteto pa ne bi ponudili nikakršne dejanske utemeljenosti. Že na prvi pogled je torej očitno, da dokler država nima vsaj utemeljenega suma, da je določena oseba storila določeno kaznivo dejanje, naj ta svoja sumničenja opravlja $\mathrm{v}$ tajnosti. Dokler kazenski postopek ni vsaj v fazi preiskave, oziroma če zahteva za slednjo ni bila vložena, dokler obtožnica ni pravnomočna, bi moral postopek ostati tajen. Predkazenski postopek mora torej potekati tajno. Več o tej dilemi v tretjem poglavju.

\subsection{Zakonodajna ureditev in informacije javnega značaja}

Eno temeljnih načel kazenskega postopka je načelo javnosti. To načelo zagotavlja nadzor demokratične javnosti nad delom sodišča in s tem zagotavlja »elementarno podlago pred samovoljnostjo ter spodbuja k pravični izvedbi kaženskega postopka.« (Dežman \& Erbežnik, 2003: 258). Če je načelo javnosti kršeno to predstavlja absolutno bistveno kršitev postopka po 4. točki prvega odstavka 371. člena ZKP, kar pomeni, da je postopek v celoti nezakonit in se Višje sodišče $\mathrm{v}$ vsebino sodbe sploh ne spušča - kar prikazuje pomembnost spoštovanja tega načela. Z obveščanjem javnosti o kazenskih postopkih, ki potekajo na sodiščih, mediji skrbijo za reprezentativnost javnosti pri sojenju - torej tistih, ki na glavni obravnavni niso oziroma ne morejo biti neposredno navzoči, s čimer mediji 
posredno prispevajo tudi k splošni prevenciji kazenskega prava (Šošić, 2015: 239). Načelo javnosti je povzdignjeno celo na ustavno raven, saj 24. člen Ustave RS določa, da so sodne obravnave javne in da se sodbe izrekajo javno, izjeme pa lahko določi le zakon. Te izjeme določa ZKP v 295. členu, in sicer je javnost mogoče izključiti, če je to potrebno za varovanje tajnosti, varstva javnega reda, morale, varstva osebnega ali družinskega življenja obtoženca ali oškodovanca ali koristi mladoletnika, ali če bi po mnenju senata javnost škodovala interesom pravičnosti. Javnost se izključi vedno, ko se sodi mladoletniku (prvi odstavek 480. člena ZKP). Sodbe pa se vedno izrekajo javno, ne glede na izključitev javnosti med glavno obravnavo.

Obenem pa ustavna določba o javnosti glavnih obravnav nesporno pomeni, da je splošna javnost v predhodnem postopku izključena! (Dežman \& Erbežnik, 2003: 259). Tudi Jakulin meni: »da v teoriji ni sporno, da sta kazenska preiskava in predkazenski postopek tajna. Mediji torej naj ne bi vedeli in poročali o posameznih preiskovalnih dejanjih zoper posameznike, zoper katere se še ni niti začel kazenski postopek." (Jakulin, 2018: 4). Če naj bo javnost izključena v predhodnem postopku (faza preiskave in kontrole obtožnice), je to še toliko bolj očitno za predkazenski postopek, saj je tam dokazni standard, ki ga ima država glede tega, da naj bi določeni osumljenec storil določeno kaznivo dejanje, še toliko nižji.

Kot smo že prikazali, se kazenski postopek formalno začne s sklepom o preiskavi in zato predkazenski postopek ne sodi med faze kazenskega postopka (Dežman \& Erbežnik, 2003: 765), in mora kot tak ostati tajen. Dejstvo pa je, da ZKP, Ustava niti katerikoli drugi pravni akt v Republiki Sloveniji neposredno ne določa tajnosti predhodnega ali predkazenskega postopka - to se je v kazenskopravnih krogih vedno smatralo kot samoumevno in razlagalo po metodi nasprotnega razlogovanja (argumentum a contrario). Ravno zato ker tako Ustava RS kot ZKP določata, da je glavna obravnava javna, medtem ko o predkazenskem in predhodnem postopku molčita, je samoumevno, da slednji dve fazi nista javni.

EKČP v 6. členu določa, da sta tisk in javnost lahko izločena iz sojenja deloma ali $\mathrm{v}$ celoti $\mathrm{v}$ interesu morale, javnega reda ali državne varnosti, če to $\mathrm{v}$ demokratični družbi zahtevajo koristi mladoletnikov ali varovanje zasebnega življenja strank, pa tudi tedaj, kadar bi po mnenju sodišča zaradi posebnih okoliščin javnost sojenja škodovala interesom pravičnosti. EKČP ne določa, da bi bila javna tudi katerakoli faza pred dejanskim sojenjem - torej pred glavno obravnavo. EKČP v 6. členu omogoča izključitev javnosti iz sojenja, če je to 
potrebno, obenem pa v 10. členu varovanje avtoritete in nepristranskosti sodstva postavlja kot eno izmed zakonitih omejitev svobode govora. Nesporno torej je, da država lahko omeji poročanje o kazenskih zadevah, če bi tako poročanje lahko pretirano vplivalo na poštenost sojenja ali na avtoriteto in nepristranskost sodstva. Ponovno pa je treba poudariti, da EKČP omenja le javnost sojenja - in ne javnost celotnega kazenskega postopka! Glede predkazenskega postopka in predhodnega postopka (predvsem faza preiskave) EKČP molči. Sklepanje po nasprotnem razlogovanju nam daje vtis, da naj bi torej te dve fazi bili tajni.

Drugi pomembni zakon, ki posega $\mathrm{v}$ vprašanje javnosti kazenskega postopka in po svoje rešuje (oziroma dodatno odpira!) dilemo tajnosti predkazenskega postopka in predhodnega kazenskega postopka pa je ZDIJZ. Pomemben stranski pravni vir so tudi odločbe Informacijskega pooblaščenca, ki je zadolžen za nadzor izvrševanja tega zakona.

ZDIJZ zavezuje vse državne organe (tudi državna tožilstva in policijo), pri čemer se kot informacija javnega značaja smatra informacija, ki izvira iz delovnega področja organa, nahaja pa se $\mathrm{v}$ obliki dokumenta, zadeve, dosjeja, registra, evidence ali drugega dokumentarnega gradiva, ki ga je organ izdelal sam, v sodelovanju z drugim organom, ali pridobil od drugih oseb (prvi odstavek 4. člena ZDIJZ). Informacije javnega značaja so prosto dostopne pravnim ali fizičnim osebam, vsak prosilec pa lahko na zahtevo pridobi od organa informacijo javnega značaja tako, da jo pridobi na vpogled, ali da pridobi njen prepis, fotokopijo, ali njen elektronski zapis (5. člen ZDIJZ).

Dosledno branje uvodnih določb ZDIJZ nam pove, da so vsi dokumenti, ki jih pridelajo državni organi v predkazenskem, predhodnem in kazenskem postopku dejansko informacije javnega značaja, katere lahko pridobi vsakdo, kar pomeni da tudi mediji, ki lahko poročajo o vsem kar policija ali državno tožilstvo raziskujeta - tipično kazenske ovadbe, ki so lahko podlaga za uvedbo preiskave ali vložitev neposredne obtožnice, vsekakor pa so le in samo to - podlaga. Temeljijo namreč na najnižjem dokaznem standardu, kjer je stopnja verjetnosti da je osumljenec v kazenski ovadbi (če je ta sploh imenovan) res storil očitano kaznivo dejanje (če je slednje sploh natančno definirano) izredno nizka. Ob tem velja ponovno omeniti, da so možne tudi anonimne in lažne kazenske ovadbe, ki jih policija prejme in začne preiskovati. Ali so take ovadbe in informacije, ki jih policija zbira $v$ predkazenskem postopku, res kar vse informacije javnega značaja? Kazenskem pravniku se ob takem vprašanju zmrači pogled. Zakonodajalec je to 
problematično situacijo predvidel, zato je v 6. členu ZDIJZ določil izjeme od dostopa do informacij javnega značaja. $V$ šesti točki prvega odstavka 6. člena ZDIJZ je določeno, da organ prosilcu zavrne dostop do zahtevane informacije, če se zahteva nanaša na podatek, ki je bil pridobljen ali sestavljen zaradi kazenskega pregona ali v zvezi z njim, ali postopka s prekrški in bi njegovo razkritje škodovalo njegovi izvedbi.

Določba je ključna za razumevanje javnosti predkazenskega postopka in predhodnega kazenskega postopka, in je tudi temeljno vodilo pri odločitvah Informacijskega pooblaščenca. Po mojem mnenju je besedilo neustavno, zakonodajalec pa očitno ne razume osnov kazenskega postopka in posledic, ki ga lahko ima za osebe v postopku. To da se zakonodajalec ob pisanju te diabolične določbe ni zavedal, da je njegova (s 34. členom Ustave RS naložena) naloga varstvo dostojanstva in zasebnosti oseb, ki se lahko znajdejo $\mathrm{v}$ takih predkazenskih in predhodnih postopkih, pa nesporno dokazuje dejstvo, da $\mathrm{v}$ sporni določbi tehta le dejanski obstoj kazenskega pregona in škodo za izvedbo tega pregona, ne pa kako bi razkritje takih informacij vplivalo na dostojanstvo oseb v predkazenskem ali predhodnem postopku.

Informacijski pooblaščenec zelo dosledno sledi zakonskemu besedilu (iz česar sklepam, da ravno tako kot naš zakonodajalec ne razume temeljnih osnov kazenskega postopka in ustavnih zagotovil zasebnosti in dostojanstva oseb, ki se znajdejo $\mathrm{v}$ teh postopkih) in je vzpostavil že povsem ustaljeno prakso odločitev ravno $\mathrm{v}$ primerih, ko so prosilci zahtevali, da se jim predajo kazenske ovadbe policije ali ovadbe, ki naj bi jih policija hranila.

V nadaljevanju povzemam način odločanja Informacijskega pooblaščenca (IP) v eni od takih zadev po odločbi 090-232/2016 z dne 7. 4. 2017.25

IP ocenjuje, da je zakonodajalec pri sprejemu ZDIJZ s tem, ko je uporabil izraz kazenski pregon, dopustil možnost, da se po 6. točki prvega odstavka 6. člena ZDIJZ varujejo vsi podatki iz vseh faz postopka kazenskega pregona. Namen opisane izjeme je predvsem zagotoviti nemoteno izvedbo postopka kazenskega pregona. Ob tem komentatorji ZDIJZ celo zapišejo, da vložitev kazenske ovadbe še ne pomeni začetka kazenskega postopka, zato se tak dokument ne varuje po obravnavani izjemi (Pirc Musar \& Kraigher Mišič, 2017: 161)!

\footnotetext{
${ }^{25}$ Enako tudi odločba št. 090-282/2015 z dne 17. 2. 2016, odločba št. 021-42/2008/2 z dne 14. 5. 2008 in še številne druge. Enako tudi (Pirc Musar \& Kraigher Mišič, 2017: 161-166).
} 
ZDIJZ v 6. točki prvega odstavka 6. člena ZDIJZ kumulativno določa dva pogoja, ki omogočata uporabo izjeme, s katero lahko organ prosilcu zavrne dostop to zahtevane informacije, in sicer:

1) da je podatek pridobljen ali sestavljen zaradi kazenskega pregona ali $v$ zvezi $z$ njim, in

2) da bi razkritje informacije škodovalo izvedbi postopka.

Prvi pogoj je izpolnjen, če se zahteva nanaša na kazensko ovadbo zaradi suma storitve kaznivih dejanj in prijave sumov storitve kaznivih dejanj - v takem primeru gre torej nedvomno za dokumente $\mathrm{v}$ zvezi s kazenskim pregonom.

V skladu s prvim odstavkom 145. člena ZKP so dolžni vsi državni organi in organizacije z javnimi pooblastili naznaniti kazniva dejanja, za katera se storilec preganja po uradni dolžnosti, če so o njih obveščeni, ali če kako drugače zvedo zanje. Ovadba se poda pristojnemu državnemu tožilcu pisno ali ustno, če je podana sodišču, policiji ali nepristojnemu državnemu tožilcu, pa jo ta sprejme in takoj pošlje pristojnemu državnemu tožilcu (prvi in tretji odstavek 147. člena ZKP). Če gre v zvezi s slednjo navedbo za kaznivo dejanje, glede katerega ni predpisano obvezno obveščanje državnega tožilca pred podajo ovadbe, pošlje policija ovadbo državnemu tožilcu šele potem, ko zbere obvestila in opravi druge ukrepe, ki so potrebni za odločitev državnega tožilca, vendar najkasneje v 30 dneh od podaje ovadbe, oziroma če $\mathrm{v}$ tem času ne more zbrati vseh potrebnih podatkov, pošlje državnemu tožilcu ovadbo z navedbo predvidenega roka za predložitev poročila v dopolnitev ovadbe (peti odstavek 147. člena ZKP). Če so podani razlogi za sum, da je bilo storjeno kaznivo dejanje, za katero se storilec preganja po uradni dolžnosti, mora policija ukreniti vse potrebno, da se izsledi storilec kaznivega dejanja, da se storilec ali udeleženec ne skrije ali ne pobegne, da se odkrijejo in zavarujejo sledovi kaznivega dejanja in predmeti, ki utegnejo biti dokaz in da se zberejo vsa obvestila, ki bi utegnila biti koristna za uspešno izvedbo kazenskega postopka (prvi odstavek 148. člena ZKP). V ta namen sme policija zahtevati potrebna obvestila od oseb, $v$ navzočnosti odgovorne osebe opraviti pregled določenih objektov in prostorov podjetij in drugih pravnih oseb in pregledati določeno njihovo dokumentacijo,... (drugi odstavek 148. člena ZKP). Iz navedenih določb tako izhaja okviren potek kazenskega pregona s strani policije in državnega tožilstva ter tudi postopanje oziroma pristojnosti policije $\mathrm{v}$ primeru, ko državno tožilstvo (še) ni vključeno v kazenski pregon. 
Navedenemu pritrjuje tudi sodba Upravnega sodišča št. I U 1324/2009-13,26 iz katere izhaja, da zakonska določba 6. točke prvega odstavka 6. člena ZDIJZ ne določa, da bi moral biti zahtevani podatek od vsega začetka ustvarjen zaradi kazenskega pregona, ampak da je bil pridobljen zaradi kazenskega pregona, torej ne glede na to, kdaj je bil pridobljen zaradi kazenskega pregona.

Drugi pogoj najprej zahteva, da je postopek še v teku (v katerikoli fazi). Postopek je $\mathrm{v}$ teku dokler kazenska ovadba ni zavržena ali postopek ustavljen - očitno v slednjem primeru po mnenju IP, take ovadbe ne predstavljajo izjeme in morajo biti posredovane prosilcu?

Drugi pogoj zavezuje organ k uporabi tako imenovanega škodnega testa (ang. harm test), po katerem mora organ izkazati, da bi s samim razkritjem nastala določena škoda izvedbi kazenskega postopka, oziroma da bi bil ta zaradi tega ogrožen. Ogrozitev pa mora vsakokrat biti dejanska, ne le hipotetična. Zavezani organ dostop do informacij lahko zavrne, če bi njihovo razkritje ogrozilo izvedbo določenih dejanj v postopku do takšne mere, da se ne bi mogla izvesti ali bi bila njihova izvedba zaradi razkritja težja, oziroma povezana $z$ nesorazmernimi stroški ali težavami (Pličanič, 2005: 128). Dostop do informacije je tako mogoče zavrniti le, če se tehtnica med škodo za izvedbo postopka in razkritjem informacije nagne proti škodi oziroma, če bi bila škoda, storjena izvedbi postopka, večja od pravice javnosti, da se seznani z informacijo.

Informacijski pooblaščene torej pri odločanju o pritožbi, ko državni organ (naj bo to policija ali državno tožilstvo) zavrne vpogled v kazensko ovadbo, zahteva kumulativno podanost obeh pogojev in zadevo presodi $z$ vidika škodnega testa, ki pa tehta le in samo škodo, ki bo z razkritjem povzročena kazenskemu postopku in "pravico« javnosti, da se seznani $z$ zahtevano informacijo. Dostojanstvo, dobro ime in zasebnost posameznika, katerega ime se pojavlja $\mathrm{v}$ tej ovadbi, Informacijskega pooblaščenca prav nič ne briga. Vsaj delno so osebni podatki posameznika zavarovani v tretji točki prvega odstavka 6. člena, kjer je obvezen test interesa javnost: "vsi osebni podatki so labko prosto dostopna informacija

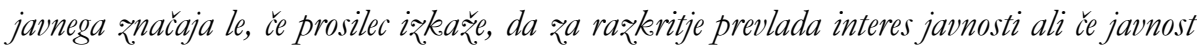
osebnega podatka določa nek drug zakon.« (Pirc Musar \& Kraigher Mišič, 2017: 140). Osebne pravice posameznika, zopet le delno, varuje tudi 7. člen ZDIJZ, ki določa delni dostop, kjer sta možna postopka anonimizacije in implementacije načela

26 Upravno sodišče (2009), odločba I U 1324/2009-13. 
sorazmernosti (Pirc Musar \& Kraigher Mišič, 2017: 149). Ob tem pa naj poudarim, da državnemu organu, vsaj na zakonski ravni, čisto nič ne preprečuje, da bi kazensko ovadbo razkril javnosti, če presodi da to kazenskemu pregonu ne škoduje. Državni organi (in to velja tudi za Informacijskega pooblaščenca) so sicer vsi zavezani Ustavi RS, ki vsebuje številne člene o posameznikovem dostojanstvu, dobremu imenu in zasebnosti (točka 2.1. prispevka), tako da me čudi, da se nihče ne sprašuje kako je z zaščito osebnostnih pravic posameznikov, ki so imensko navedeni $\mathrm{v}$ kazenski ovadbi, ki je posredovana javnosti kot informacija javnega značaja?

To še toliko bolj bode v oči, saj je po ZDIJZ interes javnosti očitno nad vsemi osebnostnimi pravicami. Državni organ mora namreč ne glede na obstoj zakonske izjeme (izdaja informacij bi škodila kazenskemu pregonu), kljub temu dopustiti dostop do podatkov, če je javni interes za razkritje močnejši od interesa pregona in interesa drugih oseb po omejitvi dostopa do zahtevane informacije (Pirc Musar \& Kraigher Mišič, 2017: 165).

\section{$3 \quad$ Kritična analiza}

Naj uvodoma prikažem enostaven primer, ki ga je po trenutni zakonodaji povsem mogoče udejaniti v praksi. Policija prejme od anonimnega prijavitelja ovadbo (prijavo) kaznivega dejanja, da naj bi ugledni profesor na Pravni fakulteti domnevno posedoval, razširjal in ustvarjal otroško pornografijo in da naj bi ga ta anonimni prijavitelj pri tem neposredno zasačil kot potencialna priča. Anonimnost ovadbe ne pomeni, da policija zadeve ne bo preiskovala, saj ima anonimna ali psevdonimna ovadba enak pomen kot ovadba znanega ovaditelja, vpliva le na večjo mero kritičnega preudarka kako ravnati s tako ovadbo (Dežman \& Erbežnik, 2003: 772). Ker gre za resno uradno pregonljivo kaznivo dejanje po tretjem odstavku 176. členu Kazenskega zakonika (KZ-1) ${ }^{27}$ z zagroženo zaporno kaznijo do osmih let, bo policija skladno s tretjim odstavkom 147. člena ZKP ovadbo posredovala državnemu tožilcu, obenem pa se lotila zadevo preučevati, skladno s pooblastili, ki jih ima po ZKP v predkazenskem postopku (predvsem 148. člen ZKP), pri čemer lahko čaka na navodila in usmeritve državnega tožilca ali pa tudi ne.

${ }^{27}$ Kazenski zakonik (KZ-1), Uradni list RS, št. 55/08 z novelami do KZ-1E, Uradni list RS, št. 27/17. 
Na podlagi take ovadbe, (morebitnih) usmeritev državnega tožilca in v policijski preiskavi zbranih obvestil, policija sestavi poročilo, s katerim dopolni ovadbo. $\mathrm{V}$ tem poročilu navede dokaze, za katere so policisti izvedeli pri njihovem zbiranju. Poročilu v dopolnitev ovadbe policija priloži tudi morebitne predmete, skice, fotografije, priskrbljena poročila, zapise o tem, kaj je ukrenila in storila, uradne zaznamke, izjave in drugo gradivo, ki utegne biti koristno za uspešno izvedbo kazenskega postopka. Policija pošlje poročilo državnemu tožilcu tudi, če na podlagi ovadbe in $\mathrm{v}$ policijski preiskavi zbranih obvestil ne odkrije ali ugotovi dovolj verjetnega razloga za sum, da je bilo kaznivo dejanje storjeno oziroma da ga je storila določena oseba. ${ }^{28}$

Ne glede na intenzivnost preiskave policije in angažiranosti državnega tožilca, pa je dejstvo, da se taka kazenska ovadba in poročilo policije nahaja pri državnem organu v obliki dokumenta, ta dokument pa je organ izdelal (delno) sam, delno pa pridobil od drugih oseb, kar pomeni da ustreza definiciji informacije javnega značaja. Pri tem se sam ne morem strinjati s komentatorji ZDIJZ, ko zapišejo, da vložitev kazenske ovadbe še ne pomeni začetka kazenskega postopka, zato se tak dokument ne varuje po izjemi 6. točke 6. člena ZDIJZ (Pirc Musar \& Kraigher Mišič, 2017: 161)! Ravno kazenska ovadba je pobuda za začetek predkazenskega postopka, tako da dejansko predstavlja tisto prvo dejanje $\mathrm{v}$ celotni verigi kazenskega postopka.

Naš anonimni prijavitelj je obenem poslal obvestilo medijem, da je bila na policijo ali državno tožilstvo vložena kazenska ovadba zoper imenovanega profesorja, ki naj bi posedoval, razširjal in ustvarjal otroško pornografijo. Mediji nemudoma posredujejo policiji in državnemu tožilstvo, kamor je bila ovadba naslovljena, zahtevo za posredovanje informacije javnega značaja, glede tega ali se preiskuje določenega profesorja za kaznivo dejanje, povezano z otroško pornografijo, oziroma naj jim posredujejo kazensko ovadbo.

Organi pregona imajo $\mathrm{v}$ tej fazi dve možnosti. Na podlagi 6. točke prvega odstavka 6. člena ZDIJZ zavrnejo dostop do informacije, saj naj bi razkritje škodovalo izvedbi kazenskega pregona. Prosilec ima možnost pritožbe Informacijskemu pooblaščencu, ki preveri ali sta podana oba kumulativna pogoja po 6. točki prvega odstavka 6. člena ZDIJZ in če zavrnitev prestane škodni test.

\footnotetext{
${ }^{28}$ Ministrstvo za notranje zadeve, Prijava kaznivega dejanja policiji https://www.policija.si/index.php/sl/novinarsko-sredie/5902-prijava-kaznivega-dejanja-policiji(28. 10. 2018).
} 
Druga možnost pa je, da organi pregona presodijo (kar je njihova diskrecijska pravica), da razkritje ne bo škodovalo kazenskemu pregonu - ker tega sploh ne bodo vodili, ker je ovadba povsem neutemeljena, ker je državni tožilec ovadbo zavrgel, ali pa celo ocenijo, da bi morda lahko kdo iz javnosti posredoval kakšno informacijo o tem kaznivem dejanju in storilcu - in tako medijem posredujejo kazensko ovadbo (pri tem lahko ovadbo anonimizirajo skladno s 7. členom ZDIJZ).

Mediji seveda nemudoma objavijo »odlično« zgodbo o tem kako policija preiskuje uglednega profesorja (ki je konkretno identificiran, lahko pa se ga tudi posredno določi iz pisanja medija) o domnevni posesti, izdelavi in razširjanju otroške pornografije. Koliko pri tem skrbijo za njegov ugled, dobro ime in dostojanstvo ${ }^{29}$ je pravzaprav brez pomena, saj ko se nekdo $\mathrm{v}$ medijih pojavi povezan $z$ otroško pornografijo (prepovedano drogo, posilstvom, nasilništvom $\mathrm{v}$ družini, mučenjem živali in drugimi podobnimi kaznivimi dejanji, ki v družbi povzročijo največji val ogorčenja), je v očeh javnost že »obsojen«, njegovo ime pa uničeno. Če bi anonimni ovaditelj namerno vložil tri ali štiri take lažne ovadbe, ki bi se na koncu vedno znašle $v$ medijih kot dobra zgodba, potem bi od profesorjevega dobrega imena ostalo bore malo. Četudi zadeve na sodišču nikoli ne bi dobile epiloga, bi mu medijsko poročanje o tem, da je v kazenskih postopkih in da ga policija preiskuje glede tako zavržnih kaznivih dejanj, uničilo njegovo dobro ime preko posrednega napada na njegovo dostojanstvo. Za uničenje dobrega imena posameznika namreč ne potrebujemo pravnomočne kazenske obsodbe, zadostuje že obsežno poročanje o zadevi!

Tu je ključno to, da je možno s pomočjo ZDIJZ dejansko pretvoriti nesmiselne klevete, opravljanje in laži v verodostojne informacije! 30 To je toliko bolj očitno $\mathrm{v}$ politični igri, kjer je napad na dobro ime posameznika ena temeljnih taktik nabiranja glasov. Če rumeni tisk objavi, da se po Mariboru šušlja ali govori, da naj bi določeni profesor posedoval otroško pornografijo, ima slednji možnost vložiti odškodninsko tožbo zoper medij ali novinarja (177. in 179. člen Obligacijskega zakonika (OZ) ${ }^{31}$ ), ima ustavno pravico do popravka in odgovora na sporno besedilo po 40. členu Ustave RS, lahko vloži zasebno kazensko obtožbo zoper novinarja zaradi kaznivega dejanja razžalitve po 158. členu KZ-1,

\footnotetext{
${ }^{29}$ In ugled organizacije, v kateri je zaposlen.

${ }^{30}$ Slovenija naj bi imela velike probleme s takimi lažnimi ovadbami. Delo (2016). Kazenske ovadbe, ki to niso, https://www.delo.si/novice/slovenija/kazenske-ovadbe-ki-to-niso.html (28. 10. 2018).

${ }^{31}$ Obligacijski zakonik (OZ), Uradni list RS, št. 83/01.
} 
obrekovanja po 159. členu KZ-1 ali žaljive obdolžitve po 160. členu KZ-1, ali vloži zahtevek za prenehanje s kršitvami osebnostnih pravic po 134. členu OZ.

Če pa mediji poročajo o tem kaj počnejo državni organi - torej poročajo o tem, da državni organi "preiskujejo« določeno osebo glede prijavljenega kaznivega dejanja - torej o informacijah javnega značaja po ZDIJZ, potem tu ni podana protipravnost, kar pomeni da vsi zgoraj navedeni pravni ukrepi niso možni oziroma bodo neuspešni. Mediji le poročajo o informacijah, ki so tako ali tako javne - in s tem ne počno nič kar je v nasprotju s pravom (razen seveda če poročajo na način, ki je za posameznika izredno žaljiv, ali če mu kršijo domnevo nedolžnosti, ali neresnično poročajo o prejetih informacijah). Obenem pa se zgodi še sledeče - informacije, ki jih mediji poročajo, ker naj bi jih dobili od državnega organa, so v javnosti bistveno bolj verodostojne, kot informacije, ki so nepreverjene. Če torej mediji poročajo da Franci iz Maribora meni, da določeni profesor poseduje otroško pornografijo, je to le nekakšna kleveta, opravljanje ali celo laž in mediji morda takih neumnosti sploh ne bodo objavili, če pa bi jih, je verodostojnost takih informacij $\mathrm{v}$ javnosti skrajno vprašljiva. Ko pa mediji objavijo, da policija in državno tožilstvo določeno osebo preiskujeta glede določenega kaznivega dejanja, ali da so to osebo preiskovali, ali da je bila podana ovadba zoper to osebo, pa je to nekaj povsem drugega. Državna organa, ki sta v državi pristojna, da preiskujeta, odkrivata in preganjata kazniva dejanja, sta namreč podala svoj pečat verodostojnosti, nečemu kar je dejansko le neumna kleveta, obrekovanje ali celo laž. S posredovanjem kazenske ovadbe javnosti ta dva, v javnosti zaupanja vredna, organa oplemenitita neko laž ali nebulozo in jo potrdita kot verjetno ali verodostojno, obenem pa medijem podata zeleno luč, da se o tem lahko poroča, ne glede na dejstvo, da država ni zadostila nobenemu resnemu dokaznemu standardu prepričanosti, da je osumljena oseba res storila to kaznivo dejanje. Glede na to, da tako medijsko poročanje hudo prizadene posameznikovo dostojanstvo in $\mathrm{v}$ tem okviru njegovo zasebnost in dobro ime, je več kot očitno, da zakonodaja, ki dopušča tako stanje ni ustavna, enako neustavno pa je tudi početje državnih organov, ki take informacije posredujejo medijem. Povsem enako je neustaven celotni škodni test, ki ga je razvil Informacijski pooblaščenec, saj ta test ne tehnici sploh ne operira s pravimi merskimi enotami. Namesto, da bi tehtal posameznikovo dostojanstvo na eni strani in pravico javnosti, da se seznani $\mathrm{z}$ določenimi javno pomembnimi informacijami, tehta slednjo pravico v primerjavi s škodo za kazenski postopek? Dostojanstvo posameznika, ki je predmet te kazenske ovadbe, njegovo zasebnost in dobro ime pa se v celoti izpusti. Taka zakonska ureditev je torej neustavna, ker 
omejuje in napada temeljne posameznikove ustavne pravice, pri tem pa ne nudi nikakršnega zagotovila, zaščite ali vsaj vrednostnega tehtanja njegovih osebnostnih pravic na eni strani, ter poštenosti kazenskega postopka in pravice javnosti do informiranosti na drugi.

Tak pristop $\mathrm{k}$ medijskemu poročanju $\mathrm{v}$ kazenskih zadevah bom poimenoval subjektivno-diskrecijski. Diskrecijski zato, ker je državnemu organu, ki vodi kazenski pregon, prepuščena odločitev ali posredovanje informacij škodi kazenskemu postopku - če se organ odloči da ne, potem lahko te informacije (npr. kazenske ovadbe), preprosto sprosti $\mathrm{v}$ javnost, pri čemer bo intenzivno poročanje o teh ovadbah uničilo dobro ime posameznika, kljub temu, da država ni izkazala nikakršnega resnega dokaznega standarda, da naj bi osumljena oseba $\mathrm{v}$ teh ovadbah res storila katero od očitanih kaznivih dejanj. Obenem pa se državni organi prav nič ne sprašuje kakšna škoda bo nastala posamezniku, čeprav bi se po načelu sorazmernosti moral spraševati.

Ta kriterij je obenem subjektivni, saj pri testu interesa javnosti loči posameznike glede na njihovo izpostavljenost javnosti. Javnosti najbolj izpostavljene osebe so javne osebnosti "par excellence« oziroma absolutno javne osebe (te v družbi praktično ne uživajo zasebnosti). Prav tako so javnosti izpostavljene relativno javne osebe, ki ne uživajo zasebnosti v povezavi z njihovo funkcijo. Največjo stopnjo zasebnosti pa uživajo zasebniki, ki javno niso izpostavljeni. Te standarde je vzpostavilo ESČP v zadevi Von Hannover v. Nemčija. ${ }^{32}$

Glede na vse predstavljene dileme in pomisleke menim, da bi morali na zakonski ravni vzpostaviti objektivno-formalni pristop do medijskega poročanja $\mathrm{v}$ kazenskih zadevah. To pomeni, da bi bili postavljeni strogi standardi, kdaj država lahko posreduje medijem informacije javnega značaja (formalni kriterij), obenem pa bi bilo posredovanje informacij v kazenskih postopkih vezano na dokazni standard, ki ga država izpolnjuje v kazenski zadevi, in ne na "javnost« posameznika (objektivni kriterij). Kar pomeni, da bi se vse posameznike v kazenskem postopku obravnavalo na enak način.

Ključno vprašanje ostane le še $v$ kateri fazi kazenskega postopka lahko državni organi posredujejo informacije o kazenskem pregonu medijem?

32 Evropsko sodišče za človekove pravice (2012), št. 40660/08 in 60641/08. 
Kot prvi možni odgovor ponudim stališče kazenskopravne teorije, ki pojmuje da sta tako predkazenski kot predhodni kazenski postopek (torej faza preiskave in kontrole obtožnice) tajna in da je javnost izključena (Dežman \& Erbežnik, 2003: 259; Jakulin, 2018: 4). Državni organi naj medijem $\mathrm{v}$ teh fazah ne bi posredovali nikakršnih podatkov o kazenskem pregonu. Faza glavne obravnave, predobravnavni narok, narok za izrek sankcije - torej vsa dejanja, ki se odvijajo $\mathrm{v}$ sodni dvorani - pa so seveda javna in se v javnosti o njih lahko poroča.

Kot drugo alternativno možnost, kdaj državni organi lahko medijem posredujejo informacije o kazenskem pregonu, pa predlagam stadij, ko je $\mathrm{v}$ kazenskem postopku dosežen dokazni standard utemeljen sum. S tem dokaznim standardom se preiskovanje kaznivega dejanja prenese od policije na sodno vejo oblasti. Utemeljen sum dosega relativno visoko verjetnost prepričanja (vsaj polovično), da je oseba v kazenskem postopku dejanski storilec kaznivega dejanja. Ta dokazni standard se zahteva za fazo preiskave, prav tako pa tudi za potrditev obtožnice in njeno pravnomočnost. Da država doseže ta dokazni standard mora ponuditi dovolj visoko stopnjo prepričanosti, ki je podkrepljena z dovolj dokazi, da je obdolženec res morda pravi storilec kaznivega dejanja. Glede na to, da ta dokazni standard omogoča prehod na glavno obravnavo, ki je javna, bi lahko dodatno utemeljili interes javnosti, da se seznani s kazenskimi postopki, v katerih je država z že dovolj visoko stopnjo verjetnosti izkazala, da je nekdo morebitni storilec kaznivega dejanja, kar tudi na ustavni ravni upravičuje poseg $\mathrm{v}$ dostojanstvo in zasebnost tega posameznika, $\mathrm{s}$ tem da se razkrije podatke o kazenskem pregonu tega posameznika.

Nesporno pa ostaja, da predkazenski postopek mora na vsak način ostati tajen. Ta del, ko se kazenski postopek formalno sploh še ni začel, namreč vodi policija na podlagi najnižjega dokaznega standarda (razlogi za sum), ki je lahko podan že na podlagi anonimne ovadbe, klica, ali sporočila, ki pa je dejansko lahko kleveta, laž ali neresnica, katere namen je uničiti dobro ime posameznika. Državni organ, kateremu smo podelili zaupanje za pregon kaznivih dejanj, ni poklican za to, da taka neutemeljena sumničenja posreduje javnosti, s čimer dejansko napade dostojanstvo posameznika in posredno preko medijev uniči njegovo dobro ime. Glede na nizko stopnjo suma, ki ga država ima zoper tega posameznika v predkazenskem postopku, bi bil tak ukrep nesorazmeren in tako neustaven. 
Pri tem opozarjam, da to ne pomeni, da mediji ne smejo poročati o potencialnih kaznivih dejanjih, ki jih sami zaznajo ali jih zaznajo njihovi viri - torej tudi ko kazenski postopek še ne teče. Pomeni le, da državni organi svojih informacij niso dolžni posredovati medijem, torej morajo ohranijo kot tajno vse kar preučujejo znotraj predkazenskega postopka. Moj predlog torej ni nikakršna omejitev svobode govora po 10. členu EKČP, temveč je omejitev posredovanja informacij javnega značaja. Ta omejitev bi morala biti zapisana $v$ temeljnem postopkovnem zakonu o kazenskem pregonu - torej ZKP, oziroma $\mathrm{v}$ specialnem zakonu o dostopu do informacij javnega značaja - ZDIJZ.

Ker ZKP te materije sploh ne ureja, je tu podana pravna praznina, ki jo delno lahko zapolnimo s sodno argumentacijo (argumentum a contrario). Ravno zato ker tako Ustava RS kot ZKP določata, da je glavna obravnava javna, medtem ko o predkazenskem in predhodnem postopku molčita, je samoumevno, da slednja dva postopka nista javna.

ZDIJZ pa sporno materijo ureja, a po mojem obrazloženem mnenju neustavno, saj dejansko ne tehta pravih interesov - namesto interesa posameznikova dostojanstva na eni strani in pravice javnost, da se seznani $z$ informacijami o kazenskem postopku na drugi, tehta škodo za kazenski postopek nasproti pravici javnosti, da se seznani z informacijami. Zato je 6. točka prvega odstavka 6. člena ZDIJZ po mojem mnenju neustavna, prav tako pa je neustaven celoten ZDIJZ, ko se njegove določbe nanašajo na informacije, ki jih organi pregona zbirajo v predkazenskem postopku.

V praksi policija in državna tožilstva načeloma zavračajo zahteve za posredovanje informacij $\mathrm{v}$ predkazenskih in predhodnih postopkih, ker je pohvalno in po mojem mnenju pravilno, tako da ta prispevek ni kritika njihovega dela, temveč je kritika veljavne zakonodajne ureditve.

\section{$4 \quad$ Sklep}

V prispevku sem prikazal, da ko mediji poročajo o kazenskih postopkih, pride do soočenja treh ustavnih interesov - posameznikovo dostojanstvo, njegovo dobro ime in zasebnost na eni strani, interes javnosti, da se seznani s kazenskimi postopki in delovanjem organov pregona na drugi, in pravičnost kazenskega postopka na tretji. 
Veljavna zakonodaja po ZDIJZ, ki glede medijskega poročanja uporablja subjektivno-diskrecijski pristop je po mojem mnenju neustavna, saj posameznikovega dostojanstva, dobrega imena in zasebnosti v predkazenskem postopku in predhodnem kazenskem postopku sploh ne upošteva, obenem pa povsem zanemarja ustaljeno kazenskopravno doktrinarno stališče, da ste te dve fazi postopka tajni, oziroma da organi pregona medijem v tej fazi ne sporočajo informacij o pregonu kaznivega dejanja.

Sam zato predlagam, da se vzpostavi objektivno-formalni pristop do medijskega poročanja $\mathrm{v}$ kazenskih zadevah. To pomeni, da bi bili postavljeni strogi standardi, kdaj država lahko posreduje medijem informacije javnega značaja (formalni kriterij), obenem pa bi bilo posredovanje informacij $\mathrm{v}$ kazenskih postopkih vezano na dokazni standard, ki ga država izpolnjuje $\mathrm{v}$ kazenski zadevi, in ne na »javnost« posameznika (objektivni kriterij).

$\mathrm{Na}$ vprašanje kdaj oziroma $\mathrm{v}$ kateri fazi kazenskega postopka lahko državni organi posredujejo informacije o pregonu medijem ponujam dve možni rešitvi.

Kot prvi možni odgovor ponudim stališče kazenskopravne teorije, ki zagovarja, da sta tako predkazenski kot predhodni kazenski postopek (torej faza preiskave in kontole obtožnice) tajna in da je javnost izključena.

Kot drugo alternativno možnost pa predlagam stadij, ko je $\mathrm{v}$ kazenskem postopku dosežen dokazni standard utemeljeni sum - kar pomeni v času preiskave oziroma takrat ko je potrjena pravnomočnost obtožnice, oziroma ko se kazenski postopek formalno začne.

Obenem zastopam stališče, da predkazenski postopek mora na vsak način ostati tajen.

Pri tem opozarjam, da to ne pomeni, da mediji ne smejo poročati o potencialnih kaznivih dejanjih, ki jih sami zaznajo ali jih zaznajo njihovi viri - torej tudi ko kazenski postopek še ne teče. Pomeni le, da državni organi svojih informacij niso dolžni posredovati medijem, torej morajo ohranijo kot tajno vse kar preučujejo znotraj predkazenskega postopka. Moj predlog torej ni nikakršna omejitev svobode govora po 10. členu EKČP, temveč je omejitev posredovanja informacij javnega značaja. Ta omejitev bi morala biti zapisana $v$ temeljnem postopkovnem zakonu o kazenskem pregonu - torej ZKP, oziroma v specialnem zakonu o 
dostopu do informacij javnega značaja - ZDIJZ, katerega veljavno besedilo je v celotni neustavno, ko se njegove določbe nanašajo na informacije, ki jih organi pregona zbirajo $\mathrm{v}$ predkazenskem postopku.

\section{Pravni viri}

Allenet de Ribemont v. Francija (1995) Evropsko sodišče za človekove pravice, št. $15175 / 89$.

Axen v. Nemčija (1984) Evropsko sodišče za človekove pravice, št. 8273/88.

Borovsky v. Slovaška (2009) Evropsko sodišče za človekove pravice, št. 24528/02.

Buscemi v. Italija (1999) Evropsko sodišče za človekove pravice, št. 29569/95.

Gaskin v. Združeno kraljestvo (1999) Evropsko sodišče za človekove pravice, št. $10454 / 83$.

Halford v. Združeno kraljestvo (1997) Evropsko sodišče za človekove pravice, št. 20605/92.

Lavents v. Latvija (2002) Evropsko sodišče za človekove pravice, št. 58442/00.

Leander v. Švedska (1987) Evropsko sodišče za človekove pravice, št. 9248/81.

Lingens v. Avstrija (1986) Evropsko sodišče za človekove pravice, št. 9815/82.

Pretto in ostali v. Italija (1984) Evropsko sodišče za človekove pravice, št. 7984/77.

Riepan v. Avstrija (2000) Evropsko sodišče za človekove pravice, št. 35115/97.

Sunday Times v. Združeno Kraljestvo (1979) Evropsko sodišče za človekove pravice, št. 6538/74.

Union Pacific Railway v. Botsford (1891) Vrhovno sodišče ZDA, 141 U.S. 251.

Von Hannover v. Nemčija (2012) Evropsko sodišče za človekove pravice, št. 40660/08 in $60641 / 08$.

Zollman v. Združeno Kraljestvo (2003) Evropsko sodišče za človekove pravice, št. $62902 / 00$.

\section{Literatura}

Bloustein, E. (1964) Privacy as an aspect of human dignity: an answer to Dean Prosser, New York University Law Review, 39(6), pp. 962-1007.

Čebulj, J. (1992) Varstvo informacijske zasebnosti v Evropi in Sloveniji (Ljubljana: Inštitut za javno upravo pri Pravni fakulteti v Ljubljani).

Delo (2016) Kazenske ovadbe, ki to niso, Delo, 3. avg. 2016, pridobljeno iz https://www.delo.si/novice/slovenija/kazenske-ovadbe-ki-to-niso.html (28.10. 2018).

Dežman, Z. \& Erbežnik, A. (2003) Kazensko procesno pravo Republike Slovenije (Ljubljana: GV založba).

Gorkič, P. (2009) Procesna dejanja obdoľ̌enca v kaẓenskem postopku (Ljubljana: Pravna fakulteta Univerze v Ljubljani).

Horvat, Š. (2004) Zakon o kaženskem postopku (ZKP) s komentarjem (Ljubljana: GV Založba). Jakulin, V. (2018) Poročanje medijev o kazenskih postopkih, Revija Pamfil, https://www.pamfil.si.

Lampe, R. (2010) Pravo človekovih pravic (Ljubljana: Uradni list RS). 
Ministrstvo za notranje zadeve, Prijava kąnivega dejanja policiji, pridobljeno iz: https://www.policija.si/index.php/sl/novinarsko-sredie/5902-prijavakaznivega-dejanja-policiji (28. 10. 2018).

Pirc Musar, N. \& Kraigher Mišič, T. (eds.) Zakon o dostopu do informacij javnega značaja (ZDIJZ) :(neuradno prečišceno besedilo): s komentarjem (Ljubljana: Uradni list Republike Slovenije).

Pličanič, S. (ur.) (2005) Komentar Zakona o dostopu do informacij javnega značaja (Ljubljana: Inštitut za javno upravo pri Pravni fakulteti).

Prepeluh, U. (2005) Pravica do dostopa do informacij javnega značaja, Revus, (4), pp. 115126.

Šošić, M. (2015) Varstvo osebnostnih pravic obdolžencev pri medijskem poročanju o kazenskih postopkih, Pravnik, 132(3/4), pp. 233-257.

Šturm, L. (ur.) (2002) Komentar Ustave Republike Slovenije (Ljubljana: Fakulteta za podiplomske državne in evropske študije).

Šugman Stubbs, K. \& Gorkič, P. (2011) Dokazovanje v kazenskem postopku (Ljubljana: GV založba).

Zupančič, B. M. in ostali (2000) Ustavno kazensko procesno pravo (Ljubljana: Pasadena).

Zupančič, B. M. (1987) Legitimatio ad causam, Zbornik znanstvenih raaprav PF v Ljubljani, 47, pp. 191-218. 


\title{
Pravna ureditev prekrškov in administrativnih kazni v gospodarstvu (de lege lata)
}

\author{
Bojan TiČAr In ANDREja Primec
}

Povzetek Novela Zakona o prekrških (ZP-1J) iz leta 2016 je z uveljavitvijo administrativnih kršitev porušila obstoječo dihotomijo dveh vrst deliktov: kaznivih dejanj in prekrškov. Ker slovensko pravo ne dovoljuje, da bi bila ista kršitev hkrati sankcionirana $z$ dvema oblikama kazenskih deliktov, mora med znaki kaznivega dejanja, znaki prekrška in znaki administrative kršitve obstajati zadostna mera razlikovanja, sicer gre za nasprotovanje načelu razločnosti (lex distincta), kar posledično vodi do nespoštovanja načela določnosti pravnega pravila (lex certa). Medtem, ko je pri razmejevanju med kaznivim dejanjem in prekrškom $\mathrm{v}$ prvi vrsti treba oceniti sorazmernost med nevarnostjo in potrebo po uporabi prisile, je pri razmejevanju med administrativnim sankcioniranjem in prekrškom, treba upoštevati odvračilni namen administrativnega sankcioniranja, ki ne temelji na subjektivni odgovornosti, temveč na objektivni odgovornosti pravne osebe, ki ni preprečila škodljivih posledic posebej reguliranih področjih, $v$ širšem smislu pomembnih za delovanje finančnih trgov, čeprav bi jih glede na svojo nadzorstveno funkcijo, morala.

Ključne besede: - Zakon o prekrških - kazenski delikti • administrativna kršitev $\bullet$ prekršek $\bullet$ pravilo lex distincta •

NASLOVA AVTORJEV: Bojan Tičar, Univerza v Mariboru, Fakulteta za varnostne vede, Ljubljana, Slovenija, e-pošta: bojan.ticar@ffvv.uni-mb.si. Andreja Primec, Univerza v Mariboru, Ekonomskoposlovna fakulteta, Maribor, Slovenija, e-pošta: andreja.primec@um.si. 


\title{
Legal Regulation of Minor Ooffences and Adminstrative Violations in the Economy (de lege lata)
}

\author{
BOJAN TIČAR \& ANDREJA PRIMEC
}

\begin{abstract}
The amended Minor Offences Act (ZP-1J) in 2016 undermined existing dichotomy of the two types of delicts, i.e. criminal offences and minor offences with the introduction of administrative violations. Since Slovenian law does not permit that the same violation could be simultaneously sanctioned with two types of punitive delicts, there must be a sufficient difference between the elements of a criminal offence, of a minor offence and of an administrative violation, otherwise the principle that there must be a sufficient difference between legal rules is not respected. In determining which conduct is to be defined as a criminal offence and which as a minor offence, primarily the proportionality between the seriousness of the conduct and the need for repressive actions must be evaluated, while in determining which conduct is to be defined as an administrative violation and which as a minor offence primarily the deterrent objective of administrative sanctioning must be taken into consideration; such objective is not based on subjective liability but on the strict liability of the legal entity that did not prevent harmful consequences in special areas that are important for the functioning of the financial markets, although it should have prevented such given its supervisory function.
\end{abstract}

Keywords: • Minor Offences Act $\bullet$ punitive delicts $\bullet$ administrative violation $\bullet$ minor offence $\bullet$ lex distincta rule $\bullet$

CORRESPONDENCE ADDRESS: Bojan Tičar, University of Maribor, Faculty of Criminal Justice and Security, Ljubljana, Slovenia, e-mail: bojan.ticar@um.si. Andreja Primec, University of Maribor, Faculty of Economics and Business, Maribor, Slovenia, e-mail: andreja.primec@um.si. 
Uvod

Kaznovalno pravo v Republiki Sloveniji sistemsko urejeno na treh različnih področjih, in to na področju (1) kazenskega prava, na področju (2) prekrškovnega prava in na področju (3) administrativnih kršitev.

Med tem ko je prekrškovno pravo urejeno v splošnem zakonu o prekrških in kopici posebnih zakonov, vladnih uredb in odlokih občin, pa je administrativno sankcioniranje, kot tretja podvrsta kaznivih ravnanj, rezervirano za sankcioniranje prepovedanih ravnanj na taksativno naštetih področjih, ki jih obravnavava $\mathrm{v}$ nadaljevanju tega prispevka.

V Sloveniji je prekršek dejanje, ki pomeni kršitev zakona, uredbe vlade, odloka samoupravne lokalne skupnosti, ki je določeno kot prekršek ter je zanj predpisna sankcija za prekršek (6. člen ZP-1).

O prekrškovnem pravu v Sloveniji pišejo predvsem avtorji najnovejšega in obsežnega komentarja Zakona o prekrških (glej npr.: Čas et al., 2018). Posebej naj izpostavimo še avtorja monografije $s$ teoretičnimi razlagami pojmov in praktičnimi primeri uporabe prava o prekrških (Gril \& Viltužnik, 2013).

Prekrškovno pravo je posebna pravna disciplina, ki preučuje prekrške iz upravnokaznovalnega vidika. Prekrški namreč niso kazniva dejanja, kot jih opredeljuje kazensko pravo, ampak prepovedana ravnanja, ki imajo lastno upravno-pravno strukturo sistematiko in uporabe. Upravno-pravna narava prekrškovnega prava je $\mathrm{v}$ tem, da so prekrški lahko predpisani z upravnimi predpisi in da za njihovo sankcioniranje skrbijo predvsem $\mathrm{v}$ hitrem postopku različni upravni organi (Cijan, R. \& Grafenauer, B. 2002). Sodišča o prekrških odločajo šele na pritožbeni stopnji v sodnem postopku (na podlagi zahtev za sodno varstvo), tako da se večina prekrškovnih sankcij izvrši prej, preden pridejo zadeve na sodišče. To pa predvsem iz specifičnega razloga, ker za veliko večino prekrškov zakonodaja omogoča plačilo polovice globe, če je ta plačna najkasneje v roku osem dni po pravnomočnosti prekrškovne odločbe ali prekrškovnega plačilnega naloga (Tičar et al., 2016) 
Prekrške kot upravno kazensko kategorijo teorija in judikatura Evropskega sodišča za človekove pravice prepoznavata kot kazenske zadeve, torej kot zadeve, za katere je treba zagotoviti standarde in garancije, ki jih obsega zlasti 6. člen Evropske konvencije o varstvu človekovih pravic in temeljnih svoboščin (EKČP.) Vse navedeno zahteva zagotovitev teh standardov tudi v prekrškovnem postopku (Bele, 2002).

Novela ZP-1 (ZP-1J; 2016) je določila, da se določbe ZP-1 ne uporabljajo za administrativno sankcioniranje pravnih oseb $\mathrm{v}$ skladu $\mathrm{s}$ predpisi, ki urejajo varstvo konkurence, zavarovalni nadzor, trg vrednostnih papirjev, preprečevanje pranja denarja in predpisi, ki jih izvaja Banka Slovenije, pri čemer bo takšna ureditev mogoča le $\mathrm{v}$ predpisih, ki jih izvajajo t. i. regulatorni organi (Banka Slovenije, Agencija za varstvo konkurence, Agencija za zavarovalni nadzor, Agencija za trg vrednostnih papirjev in Urad za preprečevanje pranja denarja).

Poleg tega je novela prinesla med drugim še nekatere druge novosti, ki jih navajamo:

- izenačitev zakona in Uredbe za izvajanje uredbe EU z vidika hierarhije pravnih aktov, kadar se uporabljajo možnosti in instituti, povezani s predpisovanjem prekrškov oziroma sankcij zanje, in ki jih je sicer po določbah ZP-1 mogoče urediti le z zakonom,

- razširitev teritorialne veljavnosti ZP-1 in materialnih predpisov, ki urejajo javni red in mir, orožje ter proizvodnjo in promet $s$ prepovedanimi drogami, tudi na pripadnike Slovenske vojske, Policije in druge uradne osebe na misijah $\mathrm{v}$ tujini,

- uvedba premoženjskega kriterija za nadomestitev plačila globe in stroškov postopka v višini najmanj 300 EUR z delom v splošno korist za osebe, ki ne morejo poravnati globe,

- uvedba instituta nadomestnega zapora pri globah nad 1.000 EUR za osebe, ki ne morejo poravnati globe,

- formalna uskladitev ZP-1 z direktivo (EU) 2015/413 Evropskega parlamenta in Sveta o lažji čezmejni izmenjavi informacij o prometnih prekrških, povezanih $\mathrm{z}$ varnostjo $\mathrm{v}$ cestnem prometu (UL L, št. $68 \mathrm{z}$ dne 13. marca 2015),

- uvedba instituta napovedi pritožbe ob izdaji pisne odločbe o prekršku v hitrem postopku, 
- določitev pravne podlage za vzpostavitev enotne informacijske infrastrukture za upravljanje $z$ evidencami prekrškovnih organov pri ministrstvu za pravosodje ipd.

Z vidika naše obravnave je pomembno dejstvo, da se z novelo ZP-1J (2016) uvaja $\mathrm{v}$ slovensko ureditev administrativne kršitve, ki niso prekrški. Novela ZP-1J je tako posegla v sistemsko izvajanje prekrškovne zakonodaje, s tem, ko je na novo uredila ali bistveno spremenila določene institute. Eden ključnih posegov je bila uvedba administrativnega sankcioniranja pravnih oseb na taksativno določenih področjih, ki jim je skupna stroga regulativna ureditev. Gre za področje varstva konkurence, bančništva, zavarovalništva in trga vrednostnih papirjev

\section{Pravna ureditev prekrškov v Sloveniji}

Prekrškov, ki so sankcionirani in veljajo, je v Sloveniji veliko. Po novinarskih podatkih okoli 10.000 (Petrovčič, 2011). Kaznivih dejanj je primeroma okoli 300. Enotna evidenca vseh prekrškov na ravni države in občin ni vzpostavljena. Problematično je tudi vprašanje pravne zmote, saj so prekrški lahko urejeni v odlokih občin, ki niso objavljeni v Uradnem listu, kot ostali predpisi (Tičar et al., 2016).

V slovenskem kaznovalnem pravu tako velja dihotomija prepovednih ravnanj oziroma deliktov. O dihotomiji govorimo takrat, ko delikti glede na značilno strukturo kazensko-pravnih norm, s katerimi se določajo protipravna dejanja in kazni zanje, sicer tvorijo celoto, vendar se po pravnem pomenu dobrine, ki jo varujejo, tako zelo razlikujejo, da jih je treba upravičeno obravnavati ločeno (Orel \& Čas, 2017).

Kaznivo dejanje ima element nevarnosti oz. nujnosti varstva pravnih vrednot. Prekršek tega nima. Prekršek je formalno definiran kot kaznivo ravnanje, ki ga predpis označuje kot prekršek in je zanj predpisna sankcija za prekršek (ne glede na družbeno nevarnost ali nujnost varstva pravnih vrednot). Uvrščajo se $\mathrm{v}$ kazensko ali prekrškovno pravo glede na naravo in težo kršitve odvisno od kvantitativnih in kvalitativnih kriterijev. 
Prekrški so lažja oblika kaznivih ravnanj, za katere se ne izrekajo kazni temveč sankcije kazenske narave (globa kot glavna sankcija ter nadomestne (opomin) in stranske sankcije). Administrativne kršitve so oblika kaznivih ravnanj za katera se izreka administrativna denarna sankcija.

Dihotomija prekrškov in kaznivih dejanj sicer pomeni, da prekršek lahko "preraste« $\mathrm{v}$ kaznivo dejanje $\mathrm{s}$ stopnjevanjem intenzivnosti prepovedanega početja (npr. davčna utaja, nevarna vožnja ipd.) ali pa tudi ne (npr. tatvina - ta je vedno kaznivo dejanje in nikoli prekršek). Kdaj se to zgodi, je vprašanje sodne prakse. Ko pa se zgodi, preide pristojnost pregona in sankcioniranja prepovedanega ravnanja iz upravnih organov (izvršilne veje oblasti) na pravosodne (sodno vejo oblasti).

Prekrške lahko določijo poleg zakonov tudi uredbe Vlade RS in odloki občin. V Sloveniji je prekršek tisto dejanje, ki pomeni kršitev zakona, uredbe vlade ali odloka samoupravne lokalne skupnosti, ki je določeno kot prekršek ter je zanj predpisna sankcija za prekršek. Načelo nullum crimen nulla poena sine lege, oz. načelo zakonske določenosti kazni in kaznivih dejanj, je pri prekrških potrebno razumeti širše, saj prekrške lahko določajo tudi nižji predpisi od zakona.

Splošna ureditev prekrškov je najprej urejena s splošnim zakonom o prekrških (v nadaljevanju ZP-1), ki vsebuje materialne in procesne določbe, ne pa tudi prekrškov samih. Le-ti so urejeni $\mathrm{v}$ drugih predpisih, posebnih zakonih, uredbah vlade in odlokih občin.

ZP-1 je sistemski zakon, ki določa splošne pogoje za predpisovanje prekrškov in sankcij zanje, splošne pogoje za odgovornost za prekrške, za izrekanje in za izvršitev sankcij prekrške, postopek za prekrške ter organe in sodišča za odločanje o njih (Selinšek, 2003).

Zp-1 je tudi splošni zakon (lex generalis), ki deluje po principu subsidiarnosti ) nadomestne uporabe). Upravlja se takrat, posebni zakoni zakonske materije ne uredijo drugače (lex specialis derogat lex generalis). Sicer pa ZP-1 določa:

- splošne pogoje za predpisovanje prekrškov in sankcij zanje;

- splošne pogoje za odgovornost za prekrške, za izrekanje in za izvršitev sankcij za prekrške;

- postopek za prekrške ter 
- organe pristojne za odločanje o prekrških.

Storilec prekrška je v Sloveniji tako lahko: vsaka opravilno sposobna fizična oseba (tudi mladoletnik po 14 letu), vsaka pravna oseba razen države in občin, i prekrška ne morejo storiti, vsaka odgovorna oseba pravne osebe, vsak samostojni podjetnik (s.p.) posameznik in vsi posamezniki, ki opravljajo drugo dejavnost (in niso s.p.; npr. lekarnarji, zdravniki, novinarji, odvetniki ipd.)

Pri prekrških sta možna dva postopka. Najprej hitri in nato sodni. Hitri postopek vodijo prekrškovni organi, ki imajo po posebnih zakonih stvarno in personalno pristojnost (npr. policija, inšpektorati, upravne enote, mestna in občinska redarstva ipd.). V njihovem imenu prekrškovni postopek vodijo pooblaščene uradne osebe s V. stopnjo izobrazbe, ki lahko izdajo plačilni nalog (enostavni formular za izrekanje globe) ali pooblaščene uradne osebe s VI. stopnjo izobrazbe, ki lahko izdajo tudi prekrškovno odločbo (bolj kompleksen individualni pravni akt organa prve stopnje).

Zoper odločitve organov na prvi stopnji je možna zahteva za sodno varstvo, ki povzroči potek sodnega prekrškovnega postopka. O prekrških sodijo v Sloveniji okrajna sodišča I. stopnje in to okrajni sodnik posameznik ter na pritožbeni instanci višja sodišča II. stopnje v senatu treh višjih sodnikov

Novela ZP-1 (novela J; 2016) je določila, da se določbe ZP-1 ne uporabljajo za administrativno sankcioniranje pravnih oseb $\mathrm{v}$ skladu s predpisi, ki urejajo varstvo konkurence, zavarovalni nadzor, trg vrednostnih papirjev, preprečevanje pranja denarja in predpisi, ki jih izvaja Banka Slovenije. Novela prinesla naslednjo ureditev:

- izključitev določb ZP-1 v primerih, ko bo poseben zakon uvedel administrativno sankcioniranje pravnih oseb, pri čemer bo takšna ureditev mogoča le $v$ predpisih, ki jih izvajajo t. i. regulatorni organi (Banka Slovenije, Agencija za varstvo konkurence, Agencija za zavarovalni nadzor, Agencija za trg vrednostnih papirjev in Urad za preprečevanje pranja denarja), 
Poleg tega je novela prinesla med drugim še nekatere druge novosti, kijih navajamo:

- izenačitev zakona in Uredbe za izvajanje uredbe EU z vidika hierarhije pravnih aktov, kadar se uporabljajo možnosti in instituti, povezani s predpisovanjem prekrškov oziroma sankcij zanje, in ki jih je sicer po določbah ZP-1 mogoče urediti le z zakonom,

- razširitev teritorialne veljavnosti ZP-1 in materialnih predpisov, ki urejajo javni red in mir, orožje ter proizvodnjo in promet $s$ prepovedanimi drogami, tudi na pripadnike Slovenske vojske, Policije in druge uradne osebe na misijah v tujini,

- uvedba premoženjskega kriterija za nadomestitev plačila globe in stroškov postopka v višini najmanj 300 EUR z delom v splošno korist za osebe, ki ne morejo poravnati globe,

- uvedba instituta nadomestnega zapora pri globah nad 1.000 EUR za osebe, ki ne morejo poravnati globe,

- formalna uskladitev ZP-1 z direktivo (EU) 2015/413 Evropskega parlamenta in Sveta o lažji čezmejni izmenjavi informacij o prometnih prekrških, povezanih z varnostjo v cestnem prometu (UL L, št. 68 z dne 13. marca 2015),

- uvedba instituta napovedi pritožbe ob izdaji pisne odločbe o prekršku v hitrem postopku,

- določitev pravne podlage za vzpostavitev enotne informacijske infrastrukture za upravljanje $\mathrm{z}$ evidencami prekrškovnih organov pri ministrstvu za pravosodje ipd.

Z vidika naše obravnave je pomembno dejstvo, da se z novelo ZP-1J (2016) uvaja v slovensko ureditev administrativne kršitve, ki niso prekrški. Novela ZP-1J je tako posegla v sistemsko izvajanje prekrškovne zakonodaje, $\mathrm{s}$ tem, ko je na novo uredila ali bistveno spremenila določene institute. Eden ključnih posegov je bila uvedba administrativnega sankcioniranja pravnih oseb na taksativno določenih področjih, ki jim je skupna stroga regulativna ureditev. Gre za področje varstva konkurence, bančništva, zavarovalništva in trga vrednostnih papirjev. 
Pravna ureditev administrativnih kršitev

S tem, ko je novela ZP-1J določila, da se določbe ZP-1 ne uporabljajo za administrativno sankcioniranje pravnih oseb na posebej reguliranih področjih, $\mathrm{v}$ širšem smislu pomembnih za delovanje finančnih trgov, je postavila pravno podlago za uvedbo posebne (tretje) vrste ${ }^{1}$ prepovedanih ravnanj: administrativne kršitve (3. odst. 1. člena ZP-1). Hkrati je njihovo ureditev prepustila predpisom, ki urejajo varstvo konkurence (ZPOmK-1), zavarovalni nadzor (ZZavar-1), trg vrednostnih papirjev (ZTFI), preprečevanje pranja denarja (ZPPDFT-1) in bančni nadzor (ZBan-2), ki so v pristojnosti osrednjih regulatornih organov $\mathrm{v}$ državi: Agencije za varstvo konkurence (AVK), Agencije za trg vrednostnih papirjev (ATVP), Agencije za zavarovalni nadzor (AZN), Banke Slovenije in Urada za preprečevanje pranja denarja (UPPD).

Uveljavitev administrativnih kršitev ruši obstoječo dihotomijo (dvojnost) dveh vrst deliktov: kaznivih dejanj in prekrškov. $Z$ razvrstitvijo deliktov v posamezne skupine, se poudari raven pravno zavarovane dobrine (vrednote), ki ji v primeru kršitve sledi sorazmerna sankcija. Tradicionalnemu razlikovanju med kaznivimi dejanji in prekrški, kjer istega dejanja ni mogoče hkrati opredeliti kot prekršek in kot kaznivo dejanje, bo tako sledilo še natančno razlikovanje od administrativnih kršitev.

V primerjavi z ostalima oblikama prepovedanih ravnanj, administrativne kršitve lahko zagrešijo le pravne osebe, brez navezave na ravnanje odgovornih oseb pravne osebe. Kadar bi bilo iz preventivnih razlogov nujno tudi sankcioniranje fizičnih oseb kot odgovornih oseb pravnih oseb, bi se to moralo posebej določiti v sklopu splošne prekrškovne zakonodaje. Določitev administrativnih kršitev pa je pridržana le za področje posebej reguliranih dejavnosti, ki so v pristojnosti osrednjih regulatornih organov v državi², kot tudi regulatornih organov EU.

Posledično pravne osebe odgovarjajo za storjene kršitve po načelih objektivne odgovornosti (strict liability), kar pomeni odgovornost ne glede na krivdo (naklep in malomarnost), ki ju je potrebno izkazati v primeru odgovornosti fizičnih oseb. Ker sankcija ni globa, tudi ni previdena $1 / 2$ plačila sankcije, kot je to značilno za vse globe (razen tistih na področju konkurenčnega prava).

\footnotetext{
${ }^{1}$ Predlog Zakona o spremembah in dopolnitvah Zakona o prekrških ZP-1J, str. 13

2 AVK, ATVP, AZN, UPPD in Banke Slovenije
} 
$\mathrm{Na}$ ravni EU se z administrativnimi sankcijami ukvarja tudi Uredba EU o zlorabi trga, ki je v prvi vrsti namenjena sankcioniranju določenih protipravnih ravnanj na finančnih trgih (trgovanju $\mathrm{z}$ notranjimi informacijami in tržnimi manipulacijami), $\mathrm{z}$ utemeljitvijo, da je zza zagotovitev skupnega pristopa $\mathrm{v}$ državah članicah in okrepitve njihovega odvračilnega učinka« treba določiti tudi sklop upravnih kazni in drugih upravnih ukrepov«.

V skladu z nacionalnim pravom države članice niso dolžne naložiti upravnih kazni in kazenskih sankcij za isto kršitev, vendar to lahko storijo, če to dovoljuje nacionalno pravo. Slovensko pravo ne dovoljuje, da bi bila ista kršitev hkrati sankcionirana z dvema oblikama kazenskih deliktov (s kaznivim dejanjem in prekrškom).

Natančneje, med znaki kaznivega dejanja in znaki prekrška mora obstajati zadostna mera razlikovanja, sicer gre za nasprotovanje načelu razločnosti (lex distincta), kar posledično vodi do nespoštovanja načela določnosti pravnega pravila (lex certa) $)^{3}$.

Če je namreč v pravnem redu poleg pravnega pravila, ki ima sicer jasno in določno vsebino, še drugo pravno pravilo z enako ali zelo podobno vsebino, se določnost enega in drugega pravnega pravila izgubi, kar vodi v negotovost, katero pravno pravilo uporabiti. Takšno stanje omogoča samovoljno oziroma arbitrarno uporabo prava.

Nezadostno razlikovanje med posameznimi kaznivimi ravnanji povzroča antinomijo pravnega reda, ki je v nasprotju z načeli pravne države (2. člen Ustave $\mathrm{RS}$ ) in posega $\mathrm{v}$ načelo zakonitosti $\mathrm{v}$ kazenskem pravu (prvi odstavek 28. člena Ustave RS). Ustavno sodišče je o teh vprašanjih odločalo trikrat, dvakrat je ugotovilo, da obstaja dovolj razlikovalnih znakov med kaznivim dejanjem in prekrškom, enkrat pa je ugotovilo, da temu ni tako.

Glede na izpostavljena načela slovenskega pravnega reda tudi podvajanje kršitev $\mathrm{v}$ obliki prekrška in administrativne kršitve ni dopustno. Zakonodajalec bo moral biti pri določanju administrativnih kršitev še posebej skrben in postaviti jasne razmejitvene kriterije ( $\mathrm{z}$ opredelitvijo razlikovalnih znakov), $\mathrm{v}$ razmerju do obstoječih prekrškov.

${ }^{3} \mathrm{O}$ tem glej več v (Selinšek, 2003). 
Medtem, ko je pri razmejevanju med kaznivim dejanjem in prekrškom v prvi vrsti treba oceniti sorazmernost med nevarnostjo in potrebo po uporabi prisile, je pri razmejevanju med administrativnim sankcioniranjem in prekrškom, treba upoštevati odvračilni namen administrativnega sankcioniranja, ki ne temelji na subjektivni odgovornosti, temveč na objektivni odgovornosti pravne osebe, ki ni preprečila škodljivih posledic na »finančnem trgu«, čeprav bi jih glede na svojo nadzorstveno funkcijo, morala. Namen teh vrst sankcij je torej izključno v tem, da se zagotovi spoštovanje pravil, brez presoje kakršnegakoli subjektivnega elementa ${ }^{4}$.

Ugotovljeni administrativni kršitvi sledi administrativna sankcija, katere namen je nadomestilo povzročene škode (odškodnine) oškodovancu (družbi) za kršitev. Z nadomestilom škode se njen namen izčrpa. Namen teh vrst sankcij je torej izključno $\mathrm{v}$ tem, da se zagotovi spoštovanje pravil, brez presoje kakršnegakoli subjektivnega elementa.

Njihov poudarek je na preventivnem učinkovanju, da se z relativno visokimi denarnimi sankcijami pravne osebe odvrača od izvrševanja administrativnih kršitev, medtem ko v osnovi niso namenjene »vzgoji in prevzgoji« pravne osebe in tudi retribucijski (povračilni) element takšne sankcije je lahko kvečjemu posledica, ne sme pa biti cilj oziroma namen.

Sankcije za administrativne kršitve so vselej denarne sankcije, določene v fiksnem znesku ali v odstotku od določene vrednosti (npr. letnega prometa ali višine povzročene škode). Administrativne sankcije izrekajo pristojni regulatorni organi $\mathrm{v}$ primeru kršitev predpisov z njihovega področja (t. im. regulatorni prekrški), pri čemer opozarjamo, da se je zaradi pravilnega razumevanja in razlikovanja med administrativnimi kršitvami in prekrški kot dvema različnima deliktoma, uporabe izraza regulatorni prekrški bolje izogibati.

${ }^{4}$ Odločbi Ustavnega sodišča, št. U-I-132/15-14 z dne 15. 3. 2018 in št. U-I-134/11 z dne 11. 7. 2013. 
V slovenskem pravu že obstajajo določena dejanja, sankcionirana z denarnimi kaznimi, ki ustrezajo namenom sankcioniranja administrativnih kršitev.

- Zakon o trgu finančnih instrumentov določa, da v kolikor zavezanci za posredovanje podatkov Agenciji za trg vrednostnih papirjev le-teh na njeno zahtevo, tudi $\mathrm{v}$ dodatnem roku ne posredujejo, ali ji posredujejo nepravilne, nepopolne ali zavajajoče podatke, se jim lahko naloži denarna kazen do 50.000 EUR (4. odst. 520. a člen ZTFI).

- Zakon o preprečevanju omejevanja konkurence vsebuje podobno pravilo. Če podjetje, na katero je Javna agencija RS za varstvo konkurence ( $v$ nadaljevanju agencija) naslovila zahtevo za posredovanje podatkov s sklepom, posreduje agenciji nepravilne, nepopolne ali zavajajoče podatke ali če jih ne posreduje $\mathrm{v}$ določenem roku, lahko agencija izda sklep, s katerim mu naloži denarno kazen do 50.000 eurov (4. odst. 27. člena ZPOmK-1).

V obeh primerih za izrek denarne kazni zadošča dejstvo, da se prejemniki zahteve za posredovanje podatkov nanjo niso ustrezno ali se sploh niso odzvali.

Dejanje, ki že ustreza namenu sankcioniranja administrativnih kršitev, ki pa je opredeljeno kot prekršek, je mogoče najti tudi v Zakonu o kmetijstvu. Gre za dejanje dolžnega nadzorstva iz 61. h člena, ki ga mora izvajati vodstveni ali nadzorni organ podjetja z znatno tržno močjo nad vsemi subjekti podjetja tako, da oblikuje ustrezne delovne procese ter nadzoruje in preverja ravnanje podjetja, zaposlenih ter zunanjih sodelavcev podjetja, ki ravnajo $\mathrm{v}$ imenu podjetja, tako da ne pride do nedovoljenih ravnanj $\mathrm{v}$ verigi preskrbe $\mathrm{s}$ hrano, določenih $\mathrm{v} 61 . \mathrm{f}$ členu ZKme-1.

Odgovornost podjetja za nedovoljena ravnanja deležnikov v verigi preskrbe $\mathrm{s}$ hrano temelji na opustitvi dolžnega nadzorstva in ne na iskanju »storilca« prekrška. Pri tem pa je za opustitev dolžnega nadzorstva odgovorno matično podjetje, to je podjetje, pod katerim okriljem delujejo ostale družbe (razmerje družba mati-hči). 
Tudi v drugih državah članicah (Nemčiji, Avstriji) velja, da je odgovornost pravnih oseb objektivna in ne temelji na ravnanjih posameznih krivih storilcev, temveč na opustitvi ustreznega nadzora nad izvajanjem gospodarske dejavnosti. Prav tako odgovornost matične družbe za ravnanje podrejene družbe ni tujek $\mathrm{v}$ primerljivih sistemih (parental liability).

Glede na to, da je dejanje dolžnega nadzorstva iz 61. h člena ZKme-1, ki se prične uporabljati s 1. januarjem 2019, uvedeno z zadnjo novelo Zakona o kmetijstvu, sprejeto marca 2018, medtem ko je bila novela J Zakona o prekrških, ki je ustvarila pravno podlago administrativnim kršitvam, sprejeta že aprila 2016, se upravičeno zastavlja vprašanje, koliko resno je zakonodajalec sploh nameraval poseči na področje kazenskih deliktov, ki so $\mathrm{v}$ pristojnosti določenih regulatornih organov.

\section{$4 \quad$ Sklepna razprava}

Novela ZP-1J je z dodanim 4. odst. 1. člena vzpostavila pravno podlago za uvedbo administrativnih kršitev $\mathrm{v}$ slovenskem sistemu kaznovalnega prava na določenih reguliranih področjih. Vendar je njihova uveljavitev v praksi še daleč. Zakonodajalec bo namreč na omejenem vsebinskem področju določil ustrezna pravila (de lege ferenda) in definiral administrativne kršitve, doslej pa je le izključil uporabo (materialnopravnih, procesnih in izvršilnih) določb prekrškovne zakonodaje.

Opozoriti velja, da do ustreznih sprememb predpisov, ki jih zajema določba četrtega odstavka 1. člena ZP-1, le-ta nima učinkov, temveč so še vedno v uporabi prekrškovne določbe obstoječih predpisov na podlagi ZP-1 kot sistemskega zakona za to področje.

Kljub temu, da bodo administrativne kršitve bremenile le pravne osebe, bo v postopkovna pravila, ki jih bodo urejale, potrebno vključiti tudi določene varovalke v smislu temeljnih načel, saj praksa Evropskega sodišča za človekove pravice pojem 'kazenske obtožbe' tolmači zelo široko in priznava večino garancij iz Evropske konvencije o človekovih pravicah tudi pravnim osebam, npr:

- pravna oseba mora biti seznanjena z očitano kršitvijo, 
- dana ji mora biti možnost, da se do nje opredeli in predloži dokaze $\mathrm{v}$ svojo korist,

- dokazi, ki potrjujejo obstoj očitane kršitve, morajo biti pridobljeni na zakonit način,

- izrečena sankcija mora biti ustrezno obrazložena (osnova obrazložitve je neposredna navezava na ugotovljeno kršitev),

- pravni osebi mora biti zagotovljena možnost izpodbijanja izrečene sankcije pred sodiščem, (s tem, ko izpodbija sankcijo, pravna oseba avtomatično izpodbija tudi ugotovljeno kršitev, zato o pravnem sredstvu odloča sodišče, ki je pristojno za sodno kontrolo odločitve o kršitvi),

- prepoved odločanja ne bis in idem (pravna oseba za isto kršitev ne more biti administrativno sankcionirana dvakrat ali večkrat).

Kot smo že izpostavili, je ZP-1J postavil temelje za ureditev administrativnih kršitev. Izpeljavo je prepustil zakonodajalcu, da jih uvede kot posebno vrsto deliktov na taksativno določenih področjih. Poleg njihovih vsebinskih opredelitev bo potrebno obdelati tudi druga formalna vprašanja, kot so določitev pristojnih organov za njihovo obravnavo ter postopkovna pravila.

\section{Pravni viri in zakonodaja}

KZ-1

U-I-132/15-14 z dne 15. 3. 2018

U-I-134/11 z dne 11. 7. 2013

Ustava Republike Slovenije (URS). (1991, 1997, 2000, 2003, 2004, 2006, 2013, 2016). Uradni list RS, (33/91, 42/97, 66/00, 24/03, 69/04 - UZ14, 69/04 - UZ43, 69/04 - UZ50, 68/06, 47/13 - UZ148, 47/13 - UZ90,97,99, 75/16).

- ZBan-2 - Zakon o bančništvu (Uradni list RS, št. 25/15, 44/16 ZRPPB, 77/16 - ZCKR in 41/17)

ZIN-UPB1 - Zakon o inšpekcijskem nadzoru (Uradni list RS, št. 43/07 - uradno prečiščeno besedilo in 40/14)

ZKme-1 - Zakon o kmetijstvu (Uradni list RS, št. 45/08, 57/12, 90/12 ZdZPVHVVR, 26/14, 32/15, 27/17 in 22/18)

ZLS-UPB2 - Zakon o lokalni samoupravi (Uradni list RS, št. 94/07 - uradno prečiščeno besedilo, 76/08, 79/09, 51/10, 40/12 - ZUJF, 14/15 - ZUUJFO, 11/18 ZSPDSLS-1 in 30/18)

ZORed - Zakon o občinskem redarstvu (Uradni list RS, št. 139/06 in 9/17)

ZP-1-UPB8 - Zakon o prekrških (Uradni list RS, št. 29/11 - uradno prečiščeno besedilo, 21/13, 111/13, 74/14 - odl. US, 92/14 - odl. US, 32/16 in 15/17 odl. US) 
ZPOmK-1 - Zakon o preprečevanju omejevanja konkurence (Uradni list RS, št. 36/08, 40/09, 26/11, 87/11, 57/12,39/13 - odl. US, 63/13 - ZS$\mathrm{K}, 33 / 14,76 / 15$ in $23 / 17$ )

ZPPDFT-1 - Zakon o preprečevanju pranja denarja in financiranja terorizma (Uradni list RS, št. 68/16)

ZTFI - Zakon o trgu finančnih instrumentov (Uradni list RS, št. 108/10 - uradno prečiščeno besedilo, 78/11, 55/12, 105/12 - ZBan-1J, 63/13 - ZS$\mathrm{K}, 30 / 16$ in $9 / 17$ )

ZZavar-1 - Zakon o zavarovalništvu (Uradni list RS, št. 99/10 - uradno prečiščeno besedilo, 90/12, 56/13, 63/13 - ZS-K in 93/15 - ZZavar-1)

\section{Literatura in viri}

Bele, I. (2005) Zakon o prekrških s komentarjem (Ljubljana: GV Založba), str. 53-54.

Cijan, R. \& Grafenauer, B. (2002) Upravno pravo (splošni del) (Maribor: Pravna fakulteta).

Čas P., Filipčič K., Fišer Z., Gril S., Jenull H., Kovač P., Maček Guštin Š., Orel N., Perpar M. \& Selinšek L. (2018) Zakon o prekrških s komentarjem (Ljubljana: GV Založba) .

Gril, S. \& Viltužnik, R. (2013) Pravo o prekrških (Ljubljana: Založba GV).

Orel N. \& Čas P. (2017) Materialnopravna ureditev prava prekrškov, postopek o prekršku, prakticna uporaba materialnopravnih doloch in postopka iz ZP-1 (Ljubljana: Upravna akademija).

Petrovčič, P. (2011) Poceni kazniva dejanja in dragi prekrški? O nenadzorovani inflaciji števila prekrškov in kazni zanje, Mladina, 5. avg. 2011, pridobljeno iz: https://www.mladina.si/86857/poceni-kazniva-dejanja-in-dragi-prekrski/ (12. 4. 2018).

Selinšek, L. (2003) Predpisovanje prekrškov v odlokih samoupravnih lokalnih skupnosti skladno z ZP-1, Lex localis, 1(3), pp. 103-119.

Tičar, B., Doljak, E. \& Rakar, I. (2016) Inšpekcijski nadzor na centralni in lokalni ravni ter njegov prispevek k varnosti v občinah,V: B. Flander, I. Areh in T. Pavšič Mrevlje (ur.) Zbornik povそ̨etkov: 17. slovenski dnevi varstvoslovja, str. 31 (Ljubljana: Fakulteta za varnostne vede). 


\title{
Splošna uredba o varstvu podatkov in vpliv na informacijske tehnologije
}

\author{
URŠKA KEŽMAH
}

Povzetek Prispevek obravnava novosti, ki jih v zvezi z obdelavo osebnih podatkov prinaša Splošna uredba o varstvu osebnih podatkov. Izpostavlja zlasti obveznosti upravljavcev in obdelovalcev ter pravice posameznikov, upoštevaje pri tem zakonite podlage za obdelavo osebnih podatkov. Določbe Splošne uredbe vplivajo tako na notranje poslovne procese v podjetju, ki jih je treba prilagoditi kot tudi na zunanje poslovanje. Zato so izpostavljene tudi obveznosti, ki jih ima upravljavec oz. obdelovalec do posameznika, kot tudi $\mathrm{v}$ medsebojnih pogodbenih razmerjih. Ker splošna uredba pomembno posega tudi na področje informacijske tehnologije so izpostavljene tudi zahteve, ki jih je treba izpolniti na tem področju (kot npr. prijava kršitve varstva osebnih podatkov, pošiljanje e-pošte v tržne namene, itd.).

Ključne besede: • splošna uredba (GDPR) • varstvo osebnih podatkov • pravice posameznikov • informacijska tehnologija • kršitev varstva osebnih podatkov - evidenca dejavnosti obdelave •

NASLOV AVTORJA: Urška Kežmah, Odvetniška pisarna dr. Urška Kežmah, Maribor, Slovenija, epošta: urska@kezmah.si. 


\title{
General Regulation on Data Protection and Influence on Information Technologies
}

\author{
URŠKA KEŽMAH
}

\begin{abstract}
The paper deals with the novelties regarding processing of personal data brought by the General Data Protection Regulation. It highlights, the obligations of controllers and processors and the rights of data subject, considering the legal basis for the processing of personal data. The provisions of the General Data Protection Regulation affect both the internal business processes in the company that need to be adapted as well as the external business. Therefore, the obligations of the controller or the processor to individual, as well as in mutual contractual relationships. Since the general regulation also significantly interferes with the field of information technology, the requirements that need to be fulfilled in this area (such as the reporting of the violation of personal data protection, the sending of e-mail for commercial purposes, etc.) are also highlighted.
\end{abstract}

Keywords: • General Data Protection Regulation (GDPR) • data protection $\bullet$ rights of the data subject $\bullet$ information technologies • personal data breach - records of processing activities •

CORRESPONDENCE ADDRESS: Urška Kežmah, Law Firm dr. Urška Kežmah, Maribor, Slovenija, email:urska@kezmah.si. 


\section{$1 \quad$ Uvod}

Sprejetje Splošne uredbe o varstvu podatkov brez dvoma predstavlja pomemben mejnik na področju varstva osebnih podatkov. Še zlasti, ker gre za prepis, ki ima globalen vpliv na ravnanje z osebnimi podatki. Nova pravila o zbiranju, obdelavi in hrambi osebnih podatkov namreč vplivajo prav na vsako podjetje, državni organ, ali neprofitno organizacijo, ki posluje v Evropi oz. obravnava osebne podatke državljanov EU ali rezidentov, ne glede na geografski položaj. To praktično pomeni, da je tudi npr. zdravstvena ustanova v ZDA, ki obravnava turista iz EU (in npr. pridobi njegove predhodne zdravniške izvide iz EU) z njegovimi medicinskimi podatki zavezana ravnati v skladu z določbami Splošne uredbe. Prav iz tega razloga je toliko bolj pomembno, da vsi upravljavci in obdelovalci osebnih podatkov, tudi tisti zunaj območja EU (zlasti ZDA) ustrezno uskladijo svoje poslovanje in ravnanje z osebnimi podatki tako, da bodo skladni z zahtevami Splošne uredbe. Pri tem uskladitev poslovanja na zahteve Splošne uredbe ne pomeni zgolj sprejem internih aktov ampak gre za kompleksen postopek, ki terja natančno poznavanje določb Splošne uredbe in nacionalnih predpisov, identifikacijo obdelav osebnih podatkov znotraj poslovnih procesov $\mathrm{v}$ podjetju in njihovo prilagoditev do te mere, da bodo osebni podatki posameznika varovani v skladu z zahtevami Splošne uredbe.

Med pomembnejšimi novostmi, ki jih prinaša Splošna uredba so predvsem strožje zahteve za zbiranje privolitev za zbiranje in obdelavo osebnih podatkov (posameznik mora biti tisti, ki prostovoljno in informirano poda privolitev - t. i. opt-in sistem), Pomembnejše novosti so zlasti: uvedba pravice do pozabe, pravica do prenosljivosti, dosledna uveljavitev načela odgovornosti, imenovanje pooblaščene osebe za varstvo podatkov, javljanje kršitev varstva osebnih podatkov nadzornemu organu.

Zaradi uveljavitve načela odgovornosti bo znotraj postopkov za uskladitev poslovanja na zahteve Splošne uredbe posebno pozornost nujno treba nameniti tudi pogodbenim razmerjem med upravljavci in obdelovalci. Ko se namreč osebni podatki, ki so zaščiteni po Splošni uredbi prenašajo iz podjetja v podjetje, se z njimi prenašajo tudi pravila, ki veljajo za zbiranje, obdelavo in hrambo teh podatkov. Zato določbe Splošne uredbe vplivajo tudi na ponudnike storitev v oblaku, ponudnike sistemov za upravljanje odnosov s strankami (t.i. CRM sistemi), ponudnike orodij za e-poštno trženje, itd., ki gostijo podatke, za katere veljajo določbe Splošne uredbe. 


\section{Nacionalna ureditev zaščite in varovanja podatkov}

Osnovno izhodišče za varstvo osebnih podatkov predstavlja določba Ustave Republike Slovenije (URS), ki v 38. členu določa, da je zagotovljeno varstvo osebnih podatkov. Prepovedana je uporaba osebnih podatkov v nasprotju z namenom njihovega zbiranja. Zbiranje, obdelovanje, namen uporabe, nadzor in varstvo tajnosti osebnih podatkov določa zakon. Vsakdo ima pravico seznaniti se z zbranimi osebnimi podatki, ki se nanašajo nanj, in pravico do sodnega varstva ob njihovi zlorabi.

Določba 38. člena Ustave Republike Slovenije na splošni ravni pomeni, da je ustavodajalec izbral t. i. "obdelovalni model" v zvezi z varstvom osebnih podatkov ("processing model") in ne t.i. "modela zlorabe" ("misuse model"), saj določa predvsem pravila za urejanje dopustne obdelave osebnih podatkov na zakonski ravni in ne načelne svobode obdelave in pretoka osebnih podatkov, ki je lahko le izjemoma izrecno omejena z zakonom (Predlog ZVOP-1, Poročevalec DZ, 2004).

$\mathrm{Na}$ podlagi citirane ustavne določbe je bil sprejet Zakon o varstvu osebnih podatkov (ZVOP-1), ki določa pravice, obveznosti, načela in ukrepe, s katerimi se preprečujejo neustavni, nezakoniti in neupravičeni posegi $\mathrm{v}$ zasebnost in dostojanstvo posameznika pri obdelavi osebnih podatkov. ZVOP-1 izhaja iz temeljnih načel zakonitosti in poštenosti, načela sorazmernosti in prepovedi diskriminacije.

Za zagotavljanje skladnosti pri obdelavi osebnih podatkov je tako treba nujno spoštovati določbe ZVOP-1, ki še vedno velja. ZVOP-2 je namreč še vedno v zakonodajnem postopku.

Od 25. 5. 2018 pa se uporablja tudi Uredba (EU) 2016/679 Evropskega parlamenta in Sveta $z$ dne 27. aprila 2016 o varstvu posameznikov pri obdelavi osebnih podatkov in o prostem pretoku takih podatkov ter o razveljavitvi Direktive 95/46/ES (Splošna uredba o varstvu podatkov), ki se v Sloveniji uporablja neposredno. Namen Splošne uredbe je predvsem zagotoviti varstvo pravic posameznika in njegovih osebnih podatkov (Wilson, 2018). 
V prispevku bomo zato izpostavili tako nacionalna izhodišča za varstvo osebnih podatkov, kot novosti, ki jih prinaša Splošna uredba ter njen vpliv na informacijsko tehnologijo.

\section{$3 \quad$ Opredelitev splošnih pojmov}

Osebni podatek je v skladu s 1. členom ZVOP-1 katerikoli podatek, ki se nanaša na posameznika, ne glede na obliko, v kateri je izražen. Posameznik je določena ali določljiva fizična oseba, na katero se nanaša osebni podatek. Fizična oseba je določljiva, če se jo lahko neposredno ali posredno identificira, predvsem s sklicevanjem na identifikacijsko številko ali na enega ali več dejavnikov, ki so značilni za njeno fizično, fiziološko, duševno, ekonomsko, kulturno ali družbeno identiteto, pri čemer način identifikacije ne povzroča velikih stroškov, nesorazmerno velikega napora ali ne zahteva veliko časa.

Definicija osebnega podatka po Splošni uredbi je nekoliko širša, saj je osebni podatek katera koli informacijo $\mathrm{v}$ zvezi $\mathrm{z}$ določenim ali določljivim posameznikom; določljiv posameznik je tisti, ki ga je mogoče neposredno ali posredno določiti, zlasti z navedbo identifikatorja, kot je ime, identifikacijska številka, podatki o lokaciji, spletni identifikator, ali z navedbo enega ali več dejavnikov, ki so značilni za fizično, fiziološko, genetsko, duševno, gospodarsko, kulturno ali družbeno identiteto tega posameznika. Upoštevaje definicije Splošne uredbe so osebni podatki tudi IP naslovi in ID piškotkov.

Za zagotavljanje skladnosti je treba upoštevati tudi definicijo obdelave osebnih podatkov, ki pomeni kakršnokoli delovanje ali niz delovanj, ki se izvaja v zvezi z osebnimi podatki, ki so avtomatizirano obdelani ali ki so pri ročni obdelavi del zbirke osebnih podatkov ali so namenjeni vključitvi v zbirko osebnih podatkov, zlasti zbiranje, pridobivanje, vpis, urejanje, shranjevanje, prilagajanje ali spreminjanje, priklicanje, vpogled, uporaba, razkritje s prenosom, sporočanje, širjenje ali drugo dajanje na razpolago, razvrstitev ali povezovanje, blokiranje, anonimiziranje, izbris ali uničenje; obdelava je lahko ročna ali avtomatizirana (sredstva obdelave). Avtomatizirana obdelava je obdelava osebnih podatkov s sredstvi informacijske tehnologije.

Omejitev obdelave po Splošni uredbi pomeni označevanje shranjenih osebnih podatkov zaradi omejevanja njihove obdelave $\mathrm{v}$ prihodnosti. 
Zbirka je vsak strukturiran niz osebnih podatkov, ki so dostopni v skladu s posebnimi merili, niz pa je lahko centraliziran, decentraliziran ali razpršen na funkcionalni ali geografski podlagi.

Za pravilno izvajanje Splošne uredbe je ključna določitev položaja v katerem je posamezno podjetje, javni organ ipd. glede obdelave osebnih podatkov. Bistveno je torej opredeliti ali je podjetje v vlogi upravljavca ali pogodbenega obdelovalca oz. celo podobdelovalca.

Upravljavec pomeni fizično ali pravno osebo, javni organ, agencijo ali drugo telo, ki samo ali skupaj z drugimi določa namene in sredstva obdelave; kadar namene in sredstva obdelave določa pravo Unije ali pravo države članice, se lahko upravljavec ali posebna merila za njegovo imenovanje določijo s pravom Unije ali pravom države članice.

Obdelovalec pomeni fizično ali pravno osebo, javni organ, agencijo ali drugo telo, ki obdeluje osebne podatke $\mathrm{v}$ imenu upravljavca.

Za opredelitev deležnikov posameznih obdelav osebnih podatkov je treba upoštevati tri bistvene razlikovalne elemente med upravljavcem in obdelovalcem. V vlogi obdelovalca bo nastopala tista pravna oziroma fizična oseba, ki bo obdelavo osebnih podatkov izvrševala (1) izključno $\mathbf{v}$ imenu in za račun upravljavca osebnih podatkov, (2) bo pri tem črpala podlago za obdelavo osebnih podatkov iz upravičenj upravljavca ter (3) bo v zvezi s samimi dejanji obdelave vezana na navodila upravljavca.

Od upravljavca oz. obdelovalca je treba ločiti pojem t.i. uporabnika osebnih podatkov. Uporabnik je fizična ali pravna oseba, javni organ, agencija ali drugo telo, ki so mu bili osebni podatki razkriti, ne glede na to, ali je tretja oseba ali ne. Vendar pa se javni organi, ki lahko prejmejo osebne podatke $\mathrm{v}$ okviru posamezne poizvedbe $\mathrm{v}$ skladu s pravom Unije ali pravom države članice, ne štejejo za uporabnike; obdelava teh podatkov s strani teh javnih organov poteka $\mathrm{v}$ skladu $\mathrm{z}$ veljavnimi pravili o varstvu podatkov glede na namene obdelave. 
Kršitev varnosti osebnih podatkov pomeni kršitev varnosti, ki povzroči nenamerno ali nezakonito uničenje, izgubo, spremembo, nepooblaščeno razkritje ali dostop do osebnih podatkov, ki so poslani, shranjeni ali kako drugače obdelani.

Dodatno Splošna uredba v 1. odst. 9. člena opredeljuje:

Posebne vrste osebnih podatkov - to so osebnih podatki, ki razkrivajo rasno ali etnično poreklo, politično mnenje, versko ali filozofsko prepričanje ali članstvo v sindikatu, in obdelava genskih podatkov, biometričnih podatkov za namene edinstvene identifikacije posameznika, podatkov v zvezi z zdravjem ali podatkov $\mathrm{v}$ zvezi $\mathrm{s}$ posameznikovim spolnim življenjem ali spolno usmerjenostjo.

\section{Zakonite podlage za obdelavo osebnih podatkov po Splošni uredbi}

Splošna uredba v 6. členu ureja naslednje podlage za zakonito obdelavo osebnih podatkov:

a. Privolitev - posameznik, na katerega se nanašajo osebni podatki, je privolil v obdelavo njegovih osebnih podatkov $\mathrm{v}$ enega ali več določenih namenov, Privolitev posameznika, na katerega se nanašajo osebni podatki pomeni vsako prostovoljno, konkretno, informirano in nedvoumno ravnanje v obliki izjavo izjave ali jasnega pritrdilnega dejanja, na katerega se nanašajo osebni podatki, s katerim izrazi strinjanje z obdelavo osebnih podatkov, ki se nanašajo nanj.

Pomembnejša novost pri privolitvi v obdelavo osebnih podatkov je zahteva Splošne uredbe, da mora biti privolitev dana $z$ jasnim pritrdilnim dejanjem, ki pomeni, da je posameznik, na katerega se nanašajo osebni podatki, prostovoljno, specifično, ozaveščeno in nedvoumno izrazil soglasje $\mathrm{k}$ obdelavi osebnih podatkov v zvezi z njim (kot je s pisno, tudi z elektronskimi sredstvi, ali ustno izjav)o. To lahko vključuje označitev okenca ob obisku spletne strani - t.i. opt-in privolitev, izbiro tehničnih nastavitev za storitve informacijske družbe ali katero koli drugo izjavo ali ravnanje, ki v tem okviru jasno kaže na to, da posameznik, na katerega se nanašajo osebni podatki, sprejema predlagano obdelavo svojih osebnih podatkov. Molk, vnaprej označena okenca ali nedejavnost zato ne pomenijo privolitve. Privolitev mora zajemati vse dejavnosti obdelave, izvedene 
$\mathrm{v}$ isti namen ali namene. Kadar je obdelava večnamenska, je treba privolitev dati za vse namene obdelave (Sobolewski, 2017).

Če je privolitev posameznika, na katerega se nanašajo osebni podatki, dana na podlagi zahteve z elektronskimi sredstvi, mora biti zahteva jasna in natančna, prav tako pa ne sme po nepotrebnem ovirati uporabe storitve, za katero se zagotavlja.

Kadar obdelava temelji na privolitvi posameznika, na katerega se nanašajo osebni podatki, mora biti upravljavec zmožen dokazati, da je posameznik, na katerega se nanašajo osebni podatki, privolil $\mathrm{v}$ dejanje obdelave. Zlasti $\mathrm{v}$ okviru pisne izjave o drugi zadevi morajo zaščitni ukrepi zagotoviti, da se posameznik, na katerega se nanašajo osebni podatki, zaveda dejstva, da daje privolitev in $\mathrm{v}$ kakšnem obsegu jo daje. V skladu z Direktivo Sveta 93/13/EGS mora upravljavec vnaprej pripraviti izjavo o privolitvi, ki mora biti $\mathrm{v}$ razumljivi in lahko dostopni obliki ter jasnem in preprostem jeziku in ne bi sme vsebovati nedovoljenih pogojev.

Da bi posameznik, na katerega se nanašajo osebni podatki, lahko dal ozaveščeno privolitev, moral poznati vsaj identiteto upravljavca in namene obdelave osebnih podatkov. Privolitev se ne šteje za prostovoljno, če posameznik, na katerega se nanašajo osebni podatki, nima možnosti dejanske ali prostovoljne izbire ali privolitve ne more zavrniti ali preklicati brez škode (točka 42 preambule Splošne uredbe).

Splošna uredba praviloma izključuje privolitev kot zakonito podlago $\mathrm{v}$ javnem sektorju. Za zagotovitev, da je privolitev dana prostovoljno, privolitev ne bi smela biti veljavna pravna podlaga za obdelavo osebnih podatkov v posebnem primeru, ko obstaja očitno neravnotežje med posameznikom, na katerega se nanašajo osebni podatki, in upravljavcem, zlasti kadar je upravljavec javni organ in je zato malo verjetno, da je bila privolitev dana prostovoljno $v$ vseh okoliščinah te specifične situacije. Za privolitev se domneva, da ni dana prostovoljno, če ne dovoljuje ločene privolitve za različna dejanja obdelave osebnih podatkov, čeprav bi taka ločena privolitev bila $v$ posameznem primeru ustrezna, ali če je izvajanje pogodbe, vključno z zagotavljanjem storitve, pogojeno s privolitvijo, čeprav za zadevno izvajanje taka privolitev ne bi bila potrebna (točka 43 preambule in 7 . člen Splošne uredbe). 
Posebnost velja tudi za privolitev $\mathrm{v}$ obdelavo osebnih podatkov $\mathrm{v}$ znanstvenoraziskovalne namene. $\mathrm{V}$ fazi zbiranja podatkov namreč pogosto ni mogoče $\mathrm{V}$ celoti opredeliti namena obdelave osebnih podatkov $\mathrm{v}$ znanstvenoraziskovalne namene. Posamezniki, na katere se nanašajo osebni podatki, bi zato morali imeti možnost, da dajo privolitev za nekatera znanstvenoraziskovalna področja, ob upoštevanju priznanih etičnih standardov znanstvenega raziskovanja. Posamezniki, na katere se nanašajo osebni podatki, morajo imeti možnost, da dajo privolitev le za nekatera raziskovalna področja ali dele raziskovalnih projektov v obsegu, ki ga dovoljuje predvideni namen.

Kadar gre za privolitev otroka v zvezi s storitvami informacijske družbe, ki se ponujajo neposredno otroku, je obdelava osebnih podatkov otroka zakonita, kadar ima otrok vsaj 16 let. Kadar je otrok mlajši od 16 let, je takšna obdelava zakonita le, če in kolikor takšno privolitev da ali odobri nosilec starševske odgovornosti za otroka. Države članice lahko za te namene z zakonom določijo tudi nižjo starost, če ta starost ni nižja od 13 let. Splošna uredba dodatno zahteva, da si mora upravljavec ob upoštevanju razpoložljive tehnologije v takih primerih razumno prizadevati za preveritev, ali je nosilec starševske odgovornosti za otroka dal ali odobril privolitev.

b. Pogodba - obdelava je potrebna za izvajanje pogodbe, katere pogodbena stranka je posameznik, na katerega se nanašajo osebni podatki, ali za izvajanje ukrepov na zahtevo takega posameznika pred sklenitvijo pogodbe.

c. Zakon - obdelava je potrebna za izpolnitev zakonske obveznosti, ki velja za upravljavca.

d. Življenjski interes - obdelava je potrebna za zaščito življenjskih interesov posameznika, na katerega se nanašajo osebni podatki, ali druge fizične osebe.

e. Javni interes - obdelava je potrebna za opravljanje naloge v javnem interesu ali pri izvajanju javne oblasti, dodeljene upravljavcu.

f. Zakoniti interes - obdelava je potrebna zaradi zakonitih interesov, za katere si prizadeva upravljavec ali tretja oseba, razen kadar nad takimi interesi prevladajo interesi ali temeljne pravice in svoboščine posameznika, na katerega se nanašajo osebni podatki, ki zahtevajo varstvo osebnih podatkov, zlasti kadar je posameznik, na katerega se nanašajo osebni podatki, otrok. 
Točka (f) se ne uporablja za obdelavo s strani javnih organov pri opravljanju njihovih nalog.

Upravljavec upoštevaje okoliščine posameznega primera (glede obdelave osebnih podatkov) sam določi na kateri zakoniti podlagi izvršuje obdelavo osebnih podatkov, saj so vse podlage enakovredne.

\section{Obveznosti upravljavcev/obdelovalcev po Splošni uredbi}

Splošna uredba predvideva določene aktivnosti, ki jih morajo izvesti tako upravljavci kot obdelovalci osebnih podatkov. Predvidene so zlasti naslednje aktivnosti (Miglico, 2018):

1. Prilagoditev pogodb z obdelovalci

2. Vzpostavitev evidence dejavnosti obdelav

3. Vzpostavitev postopkov za varovanje pravic posameznika

4. Obvestilo nadzornemu organu v primeru kršitev

5. Ocena učinka v zvezi z varstvom osebnih podatkov

6. Imenovanje pooblaščene osebe za varstvo osebnih podatkov

Kot je bilo že izpostavljeno, je ustrezna prilagoditev pogodb nujno potrebna za zagotovitev skladnosti obdelav osebnih podatkov z določbami Splošne uredbe. To je še posebej pomembno tudi pri ugotavljanju ali ima upravljavec varnostni incident.

\subsection{Prilagoditev pogodb $\mathrm{z}$ obdelovalci}

Upravljavec lahko v skladu z Splošno uredbo sodeluje zgolj z obdelovalci, ki zagotovijo zadostna jamstva za izvedbo ustreznih tehničnih in organizacijskih ukrepov na tak način, da obdelava izpolnjuje zahteve iz uredbe in zagotavlja varstvo pravic posameznika, na katerega se nanašajo osebni podatki. 
Obdelovalec ne sme angažirati ${ }^{1}$ drugega obdelovalca brez predhodnega posebnega ali splošnega pisnega dovoljenja upravljavca. V primeru splošnega pisnega dovoljenja mora obdelovalec upravljavca obvestiti o vseh nameravanih spremembah glede zaposlitve dodatnih obdelovalcev ali njihove zamenjave, $\mathrm{s}$ čimer se upravljavcu omogoči, da nasprotuje tem spremembam.

V pogodbah je tako treba urediti zlasti:

- naravo in namen obdelave,

- vsebino in trajanje obdelave,

- vrste osebnih podatkov,

- kategorije posameznikov, na katere se nanašajo osebni podatki,

- obveznosti in pravice pogodbenih strank (upravljavca in obdelovalca), ...

Pogodba mora zlasti določati, da obdelovalec:

(a) osebne podatke obdeluje samo po dokumentiranih navodilih upravljavca, vključno glede prenosov osebnih podatkov v tretjo državo ali mednarodno organizacijo, razen če to od njega zahteva pravo Unije ali pravo države članice, ki velja za obdelovalca; v slednjem primeru obdelovalec o tej pravni zahtevi pred obdelavo podatkov obvesti upravljavca, razen če zadevno pravo prepoveduje takšno obvestilo na podlagi pomembnih razlogov $\mathrm{v}$ javnem interesu;

(b) zagotovi, da so osebe, ki so pooblaščene za obdelavo osebnih podatkov, zavezane $\mathrm{k}$ zaupnosti ali jih $\mathrm{k}$ zaupnosti zavezuje ustrezen zakon;

(c) sprejme vse ukrepe, potrebne v skladu s členom 32 Splošne uredbe;

(d) spoštuje pogoje iz odstavkov 2 in 4 28. člena Splošne uredbe za zaposlitev drugega obdelovalca;

(e) ob upoštevanju narave obdelave pomaga upravljavcu z ustreznimi tehničnimi in organizacijskimi ukrepi, kolikor je to mogoče, pri izpolnjevanju njegovih obveznosti, da odgovori na zahteve za uresničevanje pravic posameznika, na katerega se nanašajo osebni podatki;

(f) upravljavcu pomaga pri izpolnjevanju obveznosti iz členov 32 do 36 ob upoštevanju narave obdelave in informacij, ki so dostopne obdelovalcu;

${ }^{1}$ Splošna uredba sicer uporablja izraz »zaposliti«, vendar je iz drugih jezikovnih različic možno zaključiti, da se določba nanaša na vsakovrstno sodelovanje (tudi pogodbeno, ....). 
(g) v skladu z odločitvijo upravljavca izbriše ali vrne vse osebne podatke upravljavcu po zaključku storitev $\mathrm{v}$ zvezi z obdelavo ter uniči obstoječe kopije, razen če pravo Unije ali pravo države članice predpisuje shranjevanje osebnih podatkov;

(h) da upravljavcu na voljo vse informacije, potrebne za dokazovanje izpolnjevanja obveznosti iz člena 28 , ter upravljavcu ali drugemu revizorju, ki ga pooblasti upravljavec, omogoči izvajanje revizij, tudi pregledov, in pri njih sodeluje.

Obdelovalec mora nemudoma obvestiti upravljavca, če po njegovem mnenju navodilo upravljavca krši Splošno uredbo ali druge določbe Unije ali predpisov držav članic o varstvu podatkov.

\section{Če obdelovalec krši Splošno uredbo s tem, ko določi namene in sredstva obdelave, se obdelovalec šteje za upravljavca v zvezi s to obdelavo.}

\subsection{Vzpostavitev evidenc dejavnosti obdelave}

Vsak upravljavec in predstavnik upravljavca, kadar ta obstaja, vodi evidenco dejavnosti obdelave osebnih podatkov v okviru svoje odgovornosti.

Ta evidenca vsebuje vse naslednje informacije:

(a) naziv ali ime in kontaktne podatke upravljavca in, kadar obstajajo, skupnega upravljavca, predstavnika upravljavca in pooblaščene osebe za varstvo podatkov;

(b) namene obdelave;

(c) opis kategorij posameznikov, na katere se nanašajo osebni podatki, in vrst osebnih podatkov;

(d) kategorije uporabnikov, ki so jim bili ali jim bodo razkriti osebni podatki, vključno z uporabniki v tretjih državah ali mednarodnih organizacijah;

(e) kadar je ustrezno, informacije o prenosih osebnih podatkov v tretjo državo ali mednarodno organizacijo, vključno $\mathrm{z}$ identifikacijo navedbo te tretje države ali mednarodne organizacije, $\mathrm{v}$ primeru prenosov iz drugega pododstavka člena 49(1) Splošne uredbe pa tudi dokumentacijo o ustreznih zaščitnih ukrepih;

(f) kadar je mogoče, predvidene roke za izbris različnih vrst podatkov;

(g) kadar je mogoče, splošni opis tehničnih in organizacijskih varnostnih ukrepov iz člena 32(1) Splošne uredbe. 
Evidence dejavnosti obdelave so lahko v pisni ali v elektronski obliki (3. odst. 30. člena Splošne uredbe).

Upravljavec, obdelovalec ali predstavnik upravljavca ali obdelovalca, kadar ta obstaja, morajo nadzornemu organu na njegovo zahtevo omogočiti dostop do evidenc.

Splošna uredba predvideva, da evidenc dejavnosti obdelave ni treba vzpostaviti tistim podjetjem oz. organizacijam, ki zaposlujejo manj kot 250 oseb, razen če je verjetno, da obdelava, ki jo izvaja, predstavlja tveganje za pravice in svoboščine posameznikov, na katere se nanašajo osebni podatki, in ni občasna, ali obdelava vključuje posebne vrste podatkov iz člena 9(1) ali osebne podatke v zvezi s kazenskimi obsodbami in prekrški iz člena 10 Splošne uredbe. Ne glede na določbo Splošno uredbe o vodenju evidenc dejavnosti obdelave pa je v obvestilih za javnost nadzornih organov vedno bolj jasno izraženo stališče, da velja ta obveznost tudi za manjša in srednja podjetja.

\subsection{Postopki za varovanje pravic posameznika}

III. poglavje Splošne uredbe podrobneje ureja pravice posameznika, na katerega se nanašajo osebni podatki.

Zaradi dosledne uveljavitve načela odgovornosti, sodi med pomembnejše zahteve Splošne uredbe obveznost, da se morajo posameznikom zagotoviti naslednje informacije:

- identiteta in kontaktni podatki upravljavca in njegovega predstavnika, kadar ta obstaja,

- kontaktni podatki pooblaščene osebe za varstvo podatkov, kadar ta obstaja,

- nameni, za katere se osebni podatki obdelujejo, kakor tudi pravno podlago za njihovo obdelavo,

- kadar obdelava temelji na zakonitem interesu (točka (f) člena 1. odst. 6. člena), zakonite interese, za uveljavljanje katerih si prizadeva upravljavec ali tretja oseba,

- uporabnike ali kategorije uporabnikov osebnih podatkov, če obstajajo, 
- obvestilo o prenosu osebnih podatke $\mathrm{v}$ tretjo državo ali mednarodno organizacijo, ter obstoj ali neobstoj sklepa Komisije o ustreznosti oz. sklic na ustrezne ali primerne zaščitne ukrepe in sredstva za pridobitev njihove kopije ali kje so na voljo.

Zaradi zagotovitve poštene in pregledne obdelave, mora upravljavec takrat, ko pridobi osebne podatke posamezniku, na katerega se ti nanašajo, zagotoviti naslednje dodatne informacije:

- obdobje hrambe osebnih podatkov ali, kadar to ni mogoče, merila, ki se uporabijo za določitev tega obdobja ${ }^{2}$,

- obstoj pravice, da se od upravljavca zahtevajo dostop do osebnih podatkov in popravek ali izbris osebnih podatkov ali omejitev obdelave v zvezi s posameznikom, na katerega se nanašajo osebni podatki, ali obstoj pravice do ugovora obdelavi in pravice do prenosljivosti podatkov,

- kadar obdelava temelji na točki (a) člena 6(1) ali točki (a) člena 9(2) Splošne uredbe, obstoj pravice, da se lahko privolitev kadar koli prekliče, ne da bi to vplivalo na zakonitost obdelave podatkov, ki se je na podlagi privolitve izvajala do njenega preklica;

- pravico do vložitve pritožbe pri nadzornem organu;

- ali je zagotovitev osebnih podatkov statutarna ali pogodbena obveznost ali pa obveznost, ki je potrebna za sklenitev pogodbe, ter ali mora posameznik, na katerega se nanašajo osebni podatki, zagotoviti osebne podatke ter kakšne so morebitne posledice, če se taki podatki ne zagotovijo, in

- obstoj avtomatiziranega sprejemanja odločitev, vključno z oblikovanjem profilov ter vsaj $\mathrm{v}$ takih primerih smiselne informacije o razlogih zanj, kot tudi pomen in predvidene posledice take obdelave za posameznika, na katerega se nanašajo osebni podatki.

\footnotetext{
${ }^{2}$ Pri tem je treba upoštevati zahtevo Splošne uredbe, da se podatki hranijo čim krajše možno obdobje (preambula 39 Splošne uredbe).
} 
Za izpolnitev zahtev Splošne uredbe, zato slednja upravljavcu nalaga, da mora sprejeti ustrezne ukrepe, s katerimi zagotovi posamezniku, na katerega se nanašajo osebni podatki, vse informacije iz členov 13 in 14 Splošne uredbe ter sporočila iz členov 15 do 22 in 34 Splošne uredbe, povezana z obdelavo, v jedrnati, pregledni, razumljivi in lahko dostopni obliki ter jasnem in preprostem jeziku, kar velja zlasti za vse informacije, namenjene posebej otroku. Informacije se posredujejo $\mathrm{v}$ pisni obliki ali z drugimi sredstvi, vključno z elektronskimi sredstvi. Na zahtevo posameznika, na katerega se nanašajo osebni podatki, se lahko informacije predložijo ustno, pod pogojem, da se identiteta posameznika, na katerega se nanašajo osebni podatki, dokaže z drugimi sredstvi.

Upravljavec mora posamezniku, na katerega se nanašajo osebni podatki, olajšati uresničevanje njegovih pravic.

Pomembno je, da mora upravljavec informacije o ukrepih, sprejetih na zahtevo v skladu s členi 15 do 22 Splošne uredbe, posamezniku, na katerega se nanašajo osebni podatki, zagotoviti brez nepotrebnega odlašanja in $\mathrm{v}$ vsakem primeru $\mathrm{v}$ enem mesecu po prejemu zahteve. Ta rok se lahko po potrebi podaljša za največ dva dodatna meseca ob upoštevanju kompleksnosti in števila zahtev. Upravljavec obvesti posameznika, na katerega se nanašajo osebni podatki, o vsakem takem podaljšanju $\mathrm{v}$ enem mesecu po prejemu zahteve skupaj z razlogi za zamudo. Kadar posameznik, na katerega se nanašajo osebni podatki, zahtevo predloži z elektronskimi sredstvi, se informacije, kadar je mogoče, zagotovijo z elektronskimi sredstvi, razen če posameznik, na katerega se nanašajo osebni podatki, ne zahteva drugače.

Če upravljavec ne ukrepa na zahtevo posameznika, na katerega se nanašajo osebni podatki, upravljavec takega posameznika brez odlašanja, najpozneje pa v enem mesecu po prejemu zahteve, obvesti o razlogih za neukrepanje ter o možnosti vložitve pritožbe pri nadzornem organu in možnosti uveljavljanja pravnih sredstev.

Informacije, zagotovljene na podlagi členov 13 in 14, ter vsa sporočila in ukrepi, sprejeti na podlagi členov 15 do 22 in 34, se zagotovijo brezplačno. Izjemoma lahko upravljavec informacije, ki jih posreduje na zahtevo posameznika zaračuna, vendar sam nosi breme dokazovanja, da je zahteva očitno neutemeljena ali pretirana. 
Splošna uredba loči med informacijami, ki jih je treba zagotoviti, kadar se osebni podatki pridobijo od posameznika, na katerega se nanašajo osebni podatki (13. člen) ter informacijami, ki jih je treba zagotoviti, kadar osebni podatki niso bili pridobljeni od posameznika, na katerega se ti nanašajo (14. člen).

Pri ukrepih za izvrševanje pravic posameznika je treba paziti tudi na druge pravice, ki jih ima posameznik po Splošni uredbi (npr. pravico do dostopa - 15 . člen, pravico do popravka - 16. člen, pravico do izbrisa - 17. člen, ...).

\subsection{Obveščanje nadzornega organa v primeru kršitev}

Splošna uredba vpeljuje dodaten instrument varstva posameznikovih pravic z uvedbo instituta obveznega javljanja kršitve varnosti osebnih podatkov (t.i. varnostnega incidenta).

V skladu z Splošno uredbo, se kot kršitev varstva osebnih podatkov (varnostni incident) šteje kršitev varnosti, ki povzroči nenamerno ali nezakonito uničenje, izgubo, spremembo, nepooblaščeno razkritje ali dostop do osebnih podatkov, ki so poslani, shranjeni ali kako drugače obdelani (12. tč. 1. odst. 4. člena Splošne uredbe). Slednje lahko torej pomeni, da se kot varnostni incident šteje tudi primer, ko se interno $\mathrm{v}$ podjetju npr. zaposleni seznani $\mathrm{z}$ osebnimi podatki drugega zaposlenega ali celo stranke, za takšen vpogled pa nima pooblastila. Kot varnostni incident pa se seveda šteje vsako nepooblaščeno razkritje osebnih podatkov tretjim osebam (npr. zunanje uhajanje podatkov). Za ugotavljanje in preprečevanje varnostnih incidentov je torej bistveno, da upravljavec ve, kaj so delali npr. hekerji ali zaposleni (O'Brien, 2017).

V primeru kršitve varnosti osebnih podatkov mora upravljavec brez nepotrebnega odlašanja, po možnosti pa najpozneje $\mathbf{v} 72$ urah po seznanitvi s kršitvijo, o njej obvestiti pristojni nadzorni organ v skladu s členom 55 (IP RS), razen če ni verjetno, da bi bile s kršitvijo varnosti osebnih podatkov ogrožene pravice in svoboščine posameznikov. Kadar obvestilo nadzornemu organu ni podano v 72 urah, se mu priloži navedba razlogov za zamudo.

Tudi obdelovalec mora po seznanitvi s kršitvijo varnosti osebnih podatkov brez nepotrebnega odlašanja uradno obvestiti upravljavca. 
Za pravočasno obvestilo nadzornemu organu je bistveno, da upravljavec pravočasno zazna varnostni incident in ga tudi zanesljivo potrdi. Šele od trenutka, ko upravljavec zanesljivo ugotovi, da ima varnostni incident namreč teče časovno okno 72 ur v katerem mora obvestiti nadzorni organ.

Obvestilo mora v skladu s Splošno uredbo vsebovati vsaj:

(a) opis vrste kršitve varnosti osebnih podatkov, po možnosti tudi kategorije in približno število zadevnih posameznikov, na katere se nanašajo osebni podatki, ter vrste in približno število zadevnih evidenc osebnih podatkov;

(b) sporočilo o imenu in kontaktnih podatkih pooblaščene osebe za varstvo podatkov ali druge kontaktne točke, pri kateri je mogoče pridobiti več informacij;

(c) opis verjetnih posledic kršitve varnosti osebnih podatkov;

(d) opis ukrepov, ki jih upravljavec sprejme ali katerih sprejetje predlaga za obravnavanje kršitve varnosti osebnih podatkov, pa tudi ukrepov za ublažitev morebitnih škodljivih učinkov kršitve, če je to ustrezno.

Ker pa je v praksi pogosto nemogoče, da bi upravljavci v $72 \mathrm{~h}$ urah v celoti preiskali obseg varnostnega incidenta, je možno uporabiti t.i. dvo-fazni postopek javljanja varnostnega incidenta. Saj Splošna uredba omogoča, da se lahko informacije $\mathrm{v}$ primeru, kadar in kolikor informacij ni mogoče zagotoviti istočasno, le-te zagotovijo postopoma, vendar brez nepotrebnega dodatnega odlašanja.

Upravljavec je dolžan dokumentirati vsako kršitev varnosti osebnih podatkov, vključno z dejstvi v zvezi s kršitvijo varnosti osebnih podatkov, njene učinke in sprejete popravne ukrepe.

Dodatno pa Splošna uredba za primer, kadar je verjetno, da bo kršitev varstva osebnih podatkov povzročila veliko tveganje za pravice in svoboščine posameznikov, zahteva, da upravljavec brez nepotrebnega odlašanja sporoči posamezniku, na katerega se nanašajo osebni podatki, da je prišlo do kršitve varstva osebnih podatkov (člen 34). 
V sporočilu posamezniku, na katerega se nanašajo osebni podatki, mora upravljavec $\mathrm{v}$ jasnem in preprostem jeziku opisati vrsto kršitve varstva osebnih podatkov ter podati vsaj informacije o imenu in kontaktnih podatkih pooblaščene osebe za varstvo podatkov ali druge kontaktne točke, pri kateri je mogoče pridobiti več informacij, opis verjetnih posledic kršitve varnosti osebnih podatkov ter opis ukrepov, ki jih upravljavec sprejme ali katerih sprejetje predlaga za obravnavanje kršitve varnosti osebnih podatkov, pa tudi ukrepov za ublažitev morebitnih škodljivih učinkov kršitve, če je to ustrezno.

Sporočilo posamezniku, na katerega se nanašajo osebni podatki pa v skladu z 3. odst. 34. člena Splošne uredbe ni potrebno, če je izpolnjen kateri koli izmed naslednjih pogojev:

(a) upravljavec je izvedel ustrezne tehnične in organizacijske zaščitne ukrepe in so bili ti ukrepi uporabljeni za osebne podatke, $\mathrm{v}$ zvezi s katerimi je bila storjena kršitev varstva, zlasti ukrepe, na podlagi katerih postanejo osebni podatki nerazumljivi vsem, ki niso pooblaščeni za dostop do njih, kot je šifriranje;

(b) upravljavec je sprejel naknadne ukrepe za zagotovitev, da se veliko tveganje za pravice in svoboščine posameznikov, na katere se nanašajo osebni podatki, iz odstavka 1 verjetno ne bo več udejanjilo;

(c) to bi zahtevalo nesorazmeren napor. $\mathrm{V}$ takšnem primeru se namesto tega objavi javno sporočilo ali izvede podoben ukrep, s katerim so posamezniki, na katere se nanašajo osebni podatki, enako učinkovito obveščeni (slednje je smiselno npr. $v$ primeru, ko bi šlo za varnostni incident $z$ večjim številom posameznikov, npr. vdor v elektronsko banko, itd.).

Splošna uredba dodatno določa, da lahko nadzorni organ $\mathrm{v}$ primeru, ko upravljavec posameznika, na katerega se nanašajo osebni podatki, še ni obvestil o kršitvi varstva osebnih podatkov, slednje od njega zahteva. Pred tem pa mora nadzorni organ preučiti ali je verjetno, da bi kršitev varstva osebnih podatkov povzročila veliko tveganje. Lahko pa nadzorni organ odloči, da je izpolnjen kateri koli od pogojev iz 3. odstavka 34. člena Splošne uredbe.

Ravnanje upravljavca in obdelovalca v primeru kršitve varstva osebnih podatkov, zlasti pa sprejem ustreznih ukrepov za omilitev škode, ki so jo utrpeli posamezniki, bo odločilna okoliščina tudi $\mathrm{v}$ primeru izrekanja globe s strani nadzornega organa (83. člen Splošne uredbe). 
Za izpolnitev te zahteve Splošne uredbe je zato bistveno, da upravljavci zagotovijo tako sredstva kot tudi kadre, hkrati pa uredijo tudi pogodbena razmerja z zunanjimi izvajalci. Samo ustrezno preventivno ravnanje bo namreč omogočalo učinkovito zagotavljanje varnosti in ugotavljanje morebitnih varnostnih incidentov.

\subsection{Ocena učinka v zvezi z varstvom osebnih podatkov}

Kadar je možno, da bi lahko vrsta obdelave, zlasti z uporabo novih tehnologij, ob upoštevanju narave, obsega, okoliščin in namenov obdelave povzročila veliko tveganje za pravice in svoboščine posameznikov, upravljavec pred obdelavo opravi oceno učinka predvidenih dejanj obdelave na varstvo osebnih podatkov. $\mathrm{V}$ eni oceni je lahko obravnavan niz podobnih dejanj obdelave, ki predstavljajo podobna velika tveganja.

To bi moralo veljati zlasti za obsežna dejanja obdelave, ki so namenjena obdelavi precejšnje količine osebnih podatkov na regionalni, nacionalni ali nadnacionalni ravni in bi lahko vplivali na veliko število posameznikov, na katere se nanašajo osebni podatki, ter za katere je verjetno, da bodo povzročila veliko tveganje, na primer zaradi njihove občutljivosti, kadar se $\mathrm{v}$ skladu $\mathrm{z}$ doseženo stopnjo tehnološkega znanja uporablja nova tehnologija $\mathrm{v}$ velikem obsegu, ter tudi za druga dejanja obdelave, ki povzročajo veliko tveganje za pravice in svoboščine posameznikov, na katere se nanašajo osebni podatki, zlasti kadar ta dejanja posameznikom, na katere se nanašajo osebni podatki, otežijo uresničevanje njihovih pravic.

Oceno učinka v zvezi z varstvom podatkov bi bilo treba izvesti tudi, kadar se osebni podatki obdelujejo za sprejemanje odločitev $\mathrm{v}$ zvezi z določenimi posamezniki po kakršnem koli sistematičnem in obsežnem vrednotenju osebnih vidikov v zvezi s posamezniki na podlagi oblikovanja profilov teh podatkov ali po obdelavi posebnih vrst osebnih podatkov, biometričnih podatkov ali podatkov o kazenskih obsodbah in prekrških ali s tem povezanih varnostnih ukrepih. Ocena učinka v zvezi z varstvom podatkov se zahteva tudi za spremljanje javno dostopnih območij v velikem obsegu, zlasti z uporabo optičnoelektronskih naprav. 
Upravljavec mora pri izvedbi ocene učinka v zvezi z varstvom podatkov zaprositi za mnenje pooblaščeno osebo za varstvo podatkov, kjer je ta imenovana.

Ocena učinka v zvezi z varstvom podatkov se po Splošni uredbi zahteva zlasti v primeru:

(a) sistematičnega in obsežnega vrednotenja osebnih vidikov $\mathrm{v}$ zvezi $\mathrm{s}$ posamezniki, ki temelji na avtomatizirani obdelavi, vključno z oblikovanjem profilov, in je osnova za odločitve, ki imajo pravne učinke $\mathrm{v}$ zvezi s posameznikom ali nanj na podoben način znatno vplivajo;

(b) obsežne obdelave posebnih vrst podatkov iz člena 9(1) Splošne uredbe ali osebnih podatkov v zvezi s kazenskimi obsodbami in prekrški iz člena 10 Splošne uredbe, ali

(c) obsežnega sistematičnega spremljanja javno dostopnega območja.

IP RS je izdal tudi posebne Smernice za izvajanje ocen učinka (Smernice IP RS, 2018), kjer je določil seznam vrst dejanj obdelave, za katere velja zahteva po oceni učinka.

Kadar ocena učinka $\mathrm{v}$ zvezi z varstvom podatkov pokaže, da bi zaradi neobstoječih zaščitnih ukrepov, varnostnih ukrepov in mehanizmov za ublažitev tveganja obdelava povzročila veliko tveganje za pravice in svoboščine posameznikov, in upravljavec meni, da tveganja ni mogoče ublažiti z razumnimi sredstvi v smislu razpoložljivih tehnologij in stroškov izvajanja, se mora pred začetkom dejavnosti obdelave posvetovati z nadzornim organom (36. člen Splošne uredbe).

\subsection{Imenovanje pooblaščene osebe za varstvo osebnih podatkov (DPO)}

Splošna uredba ne predpisuje obveznega imenovanja pooblaščene osebe za varstvo osebnih podatkov (t. i. DPO).

Upravljavec in obdelovalec pa morata imenovati pooblaščeno osebo za varstvo podatkov vedno, kadar (37. člen):

(a) obdelavo opravlja javni organ ali telo, razen sodišč, kadar delujejo kot sodni organ; 
(b) temeljne dejavnosti upravljavca ali obdelovalca zajemajo dejanja obdelave, pri katerih je treba zaradi njihove narave, obsega in/ali namenov posameznike, na katere se nanašajo osebni podatki, redno in sistematično obsežno spremljati, ali

(c) temeljne dejavnosti upravljavca ali obdelovalca zajemajo obsežno obdelavo posebnih vrst podatkov $\mathrm{v}$ skladu s členom 9 in ali osebnih podatkov v zvezi s kazenskimi obsodbami in prekrški iz člena 10 Splošne uredbe.

Povezana družba lahko imenuje eno pooblaščeno osebo za varstvo podatkov, če je ta pooblaščena oseba za varstvo podatkov lahko dostopna iz vsake enote.

Imenovanje pooblaščene osebe za varstvo osebnih podatkov je lahko tudi prostovoljno.

Pooblaščena oseba za varstvo podatkov je lahko član osebja upravljavca ali obdelovalca ali pa naloge opravlja na podlagi pogodbe o storitvah.

V skladu s Smernicami o pooblaščenih osebah za varstvo podatkov, ki jih je pripravila Delovna skupina za varstvo osebnih podatkov iz člena 29, je za določitev ali se obdelava izvaja $\mathrm{v}$ velikem obsegu $\mathrm{v}$ primeru imenovanju pooblaščenih oseb v vsakem primeru treba upoštevati zlasti naslednje dejavnike:

(a) število zadevnih posameznikov, na katere se nanašajo osebni podatki;

(b) količina podatkov in/ali obseg različnih podatkovnih postavk, ki se obdelujejo;

(c) trajanje ali stalnost dejavnosti obdelave podatkov in

(d) geografska razsežnost dejavnosti obdelave.

Upravljavec in obdelovalec morata zagotoviti neodvisnost pooblaščene osebe za varstvo podatkov, saj DPO pri opravljanju teh nalog ne sme prejemati nobenih navodil. DPO tudi ne sme biti razrešen ali kaznovan zaradi opravljanja svojih nalog. Splošna uredba sicer dopušča, da DPO opravlja tudi druge naloge in dolžnosti, vendar morata upravljavec ali obdelovalec zagotoviti, da zaradi vsakršnih takih nalog in dolžnosti ne pride do nasprotja interesov. 


\section{$6 \quad$ Nekatere pravice po Splošni uredbi}

V nadaljevanju bomo predstavili posamezne pravice posameznikov, ki jih uvaja Splošna uredba. Med pomembnejše pravice nedvomno sodi pravica do pozabe. Splošna uredba je vpeljala tudi pravico do prenosljivosti, pravico do popravka in omejitve obdelave, pravico do pritožbe, itd.. Splošna uredba izhaja iz izhodišča, da mora imeti posameznik, na katerega se nanašajo osebni podatki pravico do popravka osebnih podatkov v zvezi z njim in „pravico do pozabe“, kadar hramba takih podatkov krši Splošno uredbo ali pravo Unije ali pravo države članice, ki velja za upravljavca.

Dodatno Splošna uredba predvideva, da je treba posamezniku zagotoviti čim lažje uresničevanje pravic, vključno z mehanizmi, s katerimi se zahtevajo in po potrebi brezplačno pridobijo zlasti dostop do osebnih podatkov in popravek ali izbris osebnih podatkov ter uresničuje pravica do ugovora. Upravljavec bi zato moral omogočiti tudi elektronsko vlaganje zahtev, zlasti kadar se osebni podatki obdelujejo z elektronskimi sredstvi. Upravljavec mora zato na zahtevo posameznika, na katerega se nanašajo osebni podatki, odgovoriti brez nepotrebnega odlašanja in najpozneje $\mathrm{v}$ enem mesecu in $\mathrm{v}$ primeru, ko ne namerava izpolniti take zahteve, to utemeljiti.

\subsection{Pravica do pozabe (ang. Right to be forgotten)}

Pravica do pozabe, po vsebini kot jo uvaja Splošna uredba, predstavlja nadaljnjo razvojno stopnjo pravice do izbrisa (ang. right to be delisted), kot jo je oblikovalo Sodišče EU v primeru Google proti Španija (zadeva C-131/12) (Fuller, 2016). Pravica do izbrisa je po svoji vsebini predstavljala možnost, da posameznik od izdajatelja informacij ${ }^{3}$ zahteva izbris svojih osebnih podatkov. Sodišče EU pa ni zahtevalo, da se podatki iz interneta dejansko izbrišejo, zadostoval je izbris povezave do informacij oz. onemogočanje indeksiranja (Culik Döbke, 2018). Pravica do pozabe po Splošno uredbi pa je širša, saj velja za tehnološkega posrednika (Politou et al., 2018).

\footnotetext{
${ }^{3} \mathrm{~V}$ citirani zadevi Google proti Španija je namreč sodišče EU razsodilo, da je treba Direktive 95/46 razlagati tako, da mora upravljavec iskalnika zaradi spoštovanja pravic posameznika, in če so pogoji za uveljavitev pravice do izbrisa dejansko izpolnjeni, s seznama zadetkov, ki se prikaže po iskanju, opravljenem na podlagi imena osebe, odstraniti povezave na spletne strani, ki jih objavijo tretje osebe in ki vsebujejo podatke, ki se nanašajo na to osebo, tudi če to ime ali te informacije niso predhodno ali sočasno izbrisane s teh spletnih strani in tudi če je - če gre za tak primer - njihova objava na navedenih straneh sama po sebi zakonita.
} 
Posameznik, na katerega se nanašajo osebni podatki, mora imeti zlasti pravico do tega, da se njegovi osebni podatki izbrišejo in se ne obdelujejo več, kadar osebni podatki niso več potrebni za namene, za katere so bili zbrani ali kako drugače obdelani, kadar posameznik, na katerega se nanašajo osebni podatki, prekliče svojo privolitev ali ugovarja obdelavi osebnih podatkov, ki se nanašajo nanj, ali kadar obdelava njegovih osebnih podatkov kako drugače ni v skladu s to uredbo. Ta pravica je zlasti pomembna, kadar je posameznik, na katerega se nanašajo osebni podatki, dal svojo privolitev kot otrok in se ni v celoti zavedal tveganj, povezanih z obdelavo, ter želi pozneje take osebne podatke odstraniti, zlasti z interneta. Posameznik, na katerega se nanašajo osebni podatki, mora imeti možnost, da to pravico uresničuje ne glede na dejstvo, da ni več otrok. Vendar pa je nadaljnja hramba osebnih podatkov zakonita, če je to potrebno za uresničevanje pravice do svobode izražanja in obveščanja, izpolnjevanje pravnih obveznosti, izvajanje nalog $\mathrm{v}$ javnem interesu ali pri izvajanju javne oblasti, dodeljene upravljavcu, iz razlogov javnega interesa na področju javnega zdravja, za namene arhiviranja $\mathrm{v}$ javnem interesu, znanstveno- ali zgodovinskoraziskovalne namene ali statistične namene ali za uveljavljanje, izvajanje ali obrambo pravnih zahtevkov.

Za uveljavitev pravice do pozabe se terja aktivno ravnanje - zahteva posameznika, čeprav se v literaturi zagovarja stališče, da bi bilo pravilneje, da bi bilo določeno, da se podatki po določenem obdobju avtomatsko izbrišejo (Culik, Döbke, 2018).

Za učinkovitejše uresničevanje pravice do pozabe v spletnem okolju je pravico do pozabe razširjena tako, da se zahteva, da upravljavec, ki je osebne podatke objavil, sprejme razumne, tudi tehnične, ukrepe, da obvesti upravljavce, ki take osebne podatke obdelujejo, da je posameznik, na katerega se nanašajo osebni podatki, zahteval izbris vseh povezav do teh osebnih podatkov ali kopij teh osebnih podatkov. Pri tem mora upravljavec ob upoštevanju razpoložljive tehnologije in sredstev, ki jih ima na voljo, vključno s tehničnimi ukrepi, sprejeti razumne ukrepe, da bi upravljavce, ki obdelujejo osebne podatke, obvestil o zahtevi posameznika, na katerega se nanašajo osebni podatki. 
Posameznik torej lahko od upravljavca zahteva izbris njegovih osebnih podatkov, če je podan eden izmed naštetih razlogov:

(a) osebni podatki niso več potrebni $\mathrm{v}$ namene, za katere so bili zbrani ali kako drugače obdelani;

(b) posameznik, na katerega se nanašajo osebni podatki, prekliče privolitev, na podlagi katere poteka obdelava v skladu s točko (a) 1 odst. člena 6 ali točko (a) 2. odst člena 9 Splošne uredbe, in kadar za obdelavo ne obstaja nobena druga pravna podlaga;

(c) posameznik, na katerega se nanašajo osebni podatki, obdelavi ugovarja $\mathrm{v}$ skladu s 1. odst. 21. člena Splošne uredbe, za njihovo obdelavo pa ne obstajajo nobeni prevladujoči zakoniti razlogi, ali pa posameznik, na katerega se nanašajo osebni podatki, obdelavi ugovarja v skladu z 2. odst. 21. člena Splošne uredbe;

(d) osebni podatki so bili obdelani nezakonito;

(e) osebne podatke je treba izbrisati za izpolnitev pravne obveznosti v skladu s pravom Unije ali pravom države članice, ki velja za upravljavca;

(f) osebni podatki so bili zbrani v zvezi s ponudbo storitev informacijske družbe iz 1. odst. 8. člena Splošne uredbe.

Ker pa Splošna uredba zahteva popoln izbris osebnih podatkov (npr. 2. odst. 17. člena izrecno zahteva, da $\mathrm{v}$ primeru, ko upravljavec objavi osebne podatke in je posameznik zahteval izbris osebnih podatkov, mora ob upoštevanju razpoložljive tehnologije in stroškov izvajanja sprejeti razumne ukrepe, vključno s tehničnimi, da upravljavce, ki obdelujejo osebne podatke, obvesti, da posameznik, na katerega se nanašajo osebni podatki, od njih zahteva, naj izbrišejo morebitne povezave do teh osebnih podatkov ali njihove kopije) bodo v praksi brez dvoma enega od večjih izzivov za upravljavce predstavljal izbris varnostnih kopij na katerih se nahajajo osebni podatki posameznika, ki je uveljavil pravico do pozabe po Splošni uredbi. 


\subsection{Pravica do prenosljivosti}

Kadar obdelava osebnih podatkov temelji na privolitvi ali kadar je obdelava potrebna za izvajanje pogodbe in se obdelava izvaja $z$ avtomatiziranimi sredstvi ima posameznik, na katerega se nanašajo osebni podatki, pravico, da prejme osebne podatke v zvezi z njim, ki jih je posedoval upravljavcu, v strukturirani, splošno uporabljani in strojno berljivi obliki, in pravico, da te podatke posreduje drugemu upravljavcu, ne da bi ga upravljavec, ki so mu bili osebni podatki zagotovljeni, pri tem oviral.

Pri uresničevanju pravice do prenosljivosti podatkov ima posameznik, na katerega se nanašajo osebni podatki, pravico, da se osebni podatki neposredno prenesejo od enega upravljavca $\mathrm{k}$ drugemu, kadar je to tehnično izvedljivo.

Pravica do prenosljivosti pa se ne uporablja za obdelavo, potrebno za opravljanje naloge, ki se izvaja v javnem interesu ali pri izvajanju javne oblasti, dodeljene upravljavcu (20. člen Splošne uredbe).

Pravica posameznika, na katerega se nanašajo osebni podatki, do posredovanja ali prejemanja osebnih podatkov v zvezi z njim pa ne sme ustvariti obveznosti za upravljavca, da mora sprejeti ali vzdrževati sisteme za obdelavo, ki so tehnično združljivi. Kadar določeni niz osebnih podatkov zadeva več kot enega posameznika, na katerega se ti podatki nanašajo, pravica do prejemanja osebnih podatkov ne sme posegati $\mathrm{v}$ pravice in svoboščine drugih posameznikov, na katere se nanašajo osebni podatki. Poleg tega ta pravica ne sme posegati v pravico posameznika, na katerega se nanašajo osebni podatki, da zahteva izbris osebnih podatkov, in $\mathrm{v}$ omejitve te pravice, kakor je določeno v Splošni uredbi, zlasti pa ne sme pomeniti izbrisa osebnih podatkov, ki jih je posameznik, na katerega se ti nanašajo, zagotovil za izvajanje pogodbe, in sicer kolikor in dokler so osebni podatki potrebni za izvajanje te pogodbe (tč. 68 preambule Splošne uredbe).

Splošna uredba posameznim državam članicam dopušča možnost omejiti pravico do prenosljivosti (pa tudi druge pravice), če je to v potrebno in sorazmerno zaradi zaščite javne varnosti, vključno z zaščito človeškega življenja, zlasti pri odzivu na naravne nesreče ali nesreče, ki jih povzroči človek, preprečevanja, preiskovanja in pregona kaznivih dejanj ali izvrševanja kazenskih sankcij, vključno $z$ varovanjem pred grožnjami javni varnosti in njihovim preprečevanjem, ali kršitev etike za zakonsko urejene poklice, drugih pomembnih ciljev v splošnem javnem 
interesu Unije ali države članice, zlasti pomembnega gospodarskega ali finančnega interesa, vodenja javnih registrov iz razlogov splošnega javnega interesa, nadaljnje obdelave arhiviranih osebnih podatkov, da se zagotovijo specifične informacije $\mathrm{v}$ zvezi s političnim obnašanjem $\mathrm{v}$ nekdanjih totalitarnih državnih režimih, ali varstva posameznika, na katerega se nanašajo osebni podatki, ali pravic in svoboščin drugih, vključno s socialnim varstvom, javnim zdravjem in humanitarnimi nameni. Te omejitve bi morale biti skladne z zahtevami iz Listine in Evropske konvencije o varstvu človekovih pravic in temeljnih svoboščin (tč. 73 preambule Splošne uredbe).

\subsection{Pravica do omejitve obdelave}

V skladu s Splošno uredbo pomeni omejitev obdelave označevanje shranjenih osebnih podatkov zaradi omejevanja njihove obdelave v prihodnosti (3. tč. 1. odst. 4. člena Splošne uredbe).

Posameznik, na katerega se nanašajo osebni podatki, ima pravico doseči, da upravljavec omeji obdelavo, kadar velja en od naslednjih primerov:

(a) posameznik, na katerega se nanašajo osebni podatki, oporeka točnosti podatkov, in sicer za obdobje, ki upravljavcu omogoča preveriti točnost osebnih podatkov;

(b) je obdelava nezakonita in posameznik, na katerega se nanašajo osebni podatki, nasprotuje izbrisu osebnih podatkov ter namesto tega zahteva omejitev njihove uporabe;

(c) upravljavec osebnih podatkov ne potrebuje več za namene obdelave, temveč jih posameznik, na katerega se nanašajo osebni podatki, potrebuje za uveljavljanje, izvajanje ali obrambo pravnih zahtevkov;

(d) je posameznik, na katerega se nanašajo osebni podatki, vložil ugovor v zvezi z obdelavo v skladu s členom 21(1), dokler se ne preveri, ali zakoniti razlogi upravljavca prevladajo nad razlogi posameznika, na katerega se nanašajo osebni podatki. 
Kadar je bila obdelava osebnih podatkov omejena, se taki osebni podatki z izjemo njihovega shranjevanja obdelujejo le s privolitvijo posameznika, na katerega se ti nanašajo, ali za uveljavljanje, izvajanje ali obrambo pravnih zahtevkov ali zaradi varstva pravic druge fizične ali pravne osebe ali zaradi pomembnega javnega interesa Unije ali države članice.

Če je upravljavec dosegel omejitev obdelave, mora pred preklicem omejitve obdelave o tem obvesti posameznika, na katerega se nanašajo osebni podatki (18. člen Splošne uredbe). Splošna uredba v 19. členu dodatno nalaga upravljavcem dolžnost, da morajo vsakemu uporabniku, ki so mu bili osebni podatki razkriti, sporočiti vse popravke ali izbrise osebnih podatkov ali omejitve obdelave $\mathrm{v}$ skladu s členom 16, členom 17(1) in členom 18 Splošne uredbe, razen če se to izkaže za nemogoče ali vključuje nesorazmeren napor. Upravljavec mora o teh uporabnikih obvestiti posameznika, na katerega se nanašajo osebni podatki, če slednji posameznik tako zahteva.

Metode za omejitev obdelave osebnih podatkov lahko med drugim zajemajo začasni prenos izbranih podatkov $\mathrm{v}$ drug sistem za obdelavo, preprečijo dostopnost izbranih osebnih podatkov uporabnikom ali začasno odstranijo objavljene podatke s spletne strani. Pri avtomatiziranih zbirkah je treba omejitev obdelave načeloma zagotoviti s tehničnimi sredstvi na način, da se osebni podatki nadalje več ne obdelujejo in jih ni mogoče spremeniti. Dejstvo, da je obdelava osebnih podatkov omejena, moralo biti jasno navedeno v zbirki.

Vsak nadzorni organ ima v skladu s popravljalnimi pooblastili iz tč. f 2. odst. 58. člena Splošne uredbe možnost, da uvede začasno ali dokončno omejitev obdelave, vključno s prepovedjo obdelave.

\subsection{Pravica do pritožbe}

Vsak posameznik, na katerega se nanašajo osebni podatki, mora imeti pravico, da vloži pritožbo pri enem nadzornem organu, zlasti v državi članici svojega običajnega prebivališča, in pravico do učinkovitega pravnega sredstva v skladu s členom 47 Listine, kadar meni, da so njegove pravice iz Splošne uredbe kršene, ali če nadzorni organ ne obravnava pritožbe, jo v celoti ali deloma zavrže ali zavrne ali ne ukrepa, kadar je tak ukrep potreben za zaščito pravic posameznika, na katerega se nanašajo osebni podatki. Preiskavo na podlagi pritožbe je treba izvesti v obsegu, ki je v posamezni zadevi ustrezen, saj je lahko odločitev 
nadzornega organa predmet sodne presoje. Nadzorni organ mora posameznika, na katerega se nanašajo osebni podatki, v ustreznem roku obvestiti o stanju zadeve in odločitvi o pritožbi. Če mora nadzorni organ zadevo podrobneje preučiti ali se uskladiti z drugim nadzornim organom, mora posamezniku, na katerega se nanašajo osebni podatki, posredovati informacije o stanju zadeve med postopkom. Za poenostavitev postopka vložitve pritožbe mora vsak nadzorni organ sprejeti ukrepe, na primer za zagotovitev obrazca za vložitev pritožbe, ki se lahko izpolni tudi elektronsko, pri čemer niso izključena druga komunikacijska sredstva.

Upoštevaje zgoraj navedeno ima torej vsak posameznik, na katerega se nanašajo osebni podatki, brez poseganja v katero koli drugo upravno ali pravno sredstvo, pravico, da vloži pritožbo pri nadzornem organu, zlasti v državi članici, v kateri ima običajno prebivališče, $v$ kateri je njegov kraj dela ali v kateri je domnevno prišlo do kršitve, če meni, da obdelava osebnih podatkov v zvezi z njim krši Splošno uredbo (77. člen Splošne uredbe).

Vsaka fizična ali pravna oseba ima v skladu z 78. členom Splošne uredbe pravico do učinkovitega pravnega sredstva zoper pravno zavezujočo odločitev nadzornega organa v zvezi z njo.

Novost po Splošni uredbi pa je uvedba instituta "pritožbe vse na enem mestu«. Kadar obdelava osebnih podatkov poteka v okviru dejavnosti sedeža upravljavca ali obdelovalca $\mathrm{v}$ Uniji in ima upravljavec ali obdelovalec sedež $\mathbf{v}$ več kot eni državi članici ali kadar obdelava, ki poteka v okviru dejavnosti edinega sedeža upravljavca ali obdelovalca $v$ Uniji, znatno vpliva oziroma bi lahko znatno vplivala na posameznike, na katere se nanašajo osebni podatki, v več kot eni državi članici, moral nadzorni organ, pristojen za glavni sedež upravljavca ali obdelovalca ali za edini sedež upravljavca ali obdelovalca delovati kot vodilni organ. Sodelovati mora z drugimi zadevnimi organi, ker ima upravljavec ali obdelovalec sedež na ozemlju njihove države članice, ker obdelava znatno vpliva na posameznike, na katere se nanašajo osebni podatki in ki prebivajo na njihovem ozemlju, ali ker je bila pri njih vložena pritožba. Četudi je pritožbo vložil posameznik, na katerega se nanašajo osebni podatki in ki ne prebiva $\mathrm{v}$ zadevni državi članici, je nadzorni organ, pri katerem je bila vložena pritožba, tudi zadevni nadzorni organ. 
Vodilni organ je pristojen za sprejemanje zavezujočih odločitev v zvezi z ukrepi, na podlagi katerih se uporabljajo pooblastila, ki so mu bila dodeljena v skladu s Splošno uredbo. Nadzorni organ mora v vlogi vodilnega organa $\mathrm{v}$ postopek odločanja pritegniti zadevne nadzorne organe in usklajevati njihove dejavnosti. Kadar odločitev zadeva popolno ali delno zavrnitev pritožbe posameznika, na katerega se nanašajo osebni podatki, mora to odločitev sprejeti nadzorni organ, pri katerem je bila vložena pritožba.

\subsection{Pravica do ugovora}

Posameznik, na katerega se nanašajo osebni podatki, ima na podlagi razlogov, povezanih z njegovim posebnim položajem, pravico, da kadar koli ugovarja obdelavi osebnih podatkov v zvezi z njim, ki temelji na točki (e - javni interes ali izvajanje javne oblasti) ali (f - zakoniti interes) 1. odst. 6. člena Splošne uredbe, vključno z oblikovanjem profilov na podlagi teh določb. Upravljavec preneha obdelovati osebne podatke, razen če dokaže nujne legitimne razloge za obdelavo, ki prevladajo nad interesi, pravicami in svoboščinami posameznika, na katerega se nanašajo osebni podatki, ali za uveljavljanje, izvajanje ali obrambo pravnih zahtevkov.

Kadar se osebni podatki obdelujejo za namene neposrednega trženja, ima posameznik, na katerega se nanašajo osebni podatki, pravico, da kadar koli ugovarja obdelavi osebnih podatkov v zvezi z njim za namene takega trženja, vključno z oblikovanjem profilov, kolikor je povezano s takim neposrednim

trženjem. Če posameznik, na katerega se nanašajo osebni podatki, ugovarja obdelavi za namene neposrednega trženja, se osebni podatki ne obdelujejo več v te namene.

Posameznika, na katerega se nanašajo osebni podatki, se mora na pravico do ugovora izrecno opozoriti najpozneje ob prvem komuniciranju z njim in mu to pravico predstaviti jasno in ločeno od vseh drugih informacij.

$\mathrm{V}$ okviru uporabe storitev informacijske družbe in ne glede na Direktivo 2002/58/ES lahko posameznik, na katerega se nanašajo osebni podatki, uveljavlja pravico do ugovora $z$ avtomatiziranimi sredstvi z uporabo tehničnih specifikacij. 
Kadar se osebni podatki obdelujejo $\mathrm{v}$ znanstveno- ali zgodovinskoraziskovalne namene ali statistične namene v skladu z 1. odst. 89. člena Splošne uredbe, ima posameznik, na katerega se ti podatki nanašajo, pravico, da iz razlogov, povezanih $z$ njegovim posebnim položajem, ugovarja obdelavi osebnih podatkov v zvezi z njim, razen če je obdelava potrebna za opravljanje naloge, ki se izvaja zaradi razlogov javnega interesa (21. člen Splošne uredbe).

\section{$7 \quad$ Varstvo osebnih podatkov po ZEKom-1}

ZEKom-1 kot specialni predpis na področju varstva osebnih podatkov izrecno določa, da morajo izvajalci javnih komunikacijskih storitev sprejeti ustrezne tehnične in organizacijske ukrepe za zagotovitev zavarovanja svojih storitev. Če je to potrebno za zagotovitev zavarovanja svojih storitev v delu, ki se nanaša na varnost omrežja, morajo sprejeti ustrezne tehnične in organizacijske ukrepe skupaj s ponudnikom javnega komunikacijskega omrežja. Ukrepi morajo ob upoštevanju tehnološkega razvoja in stroškov njihove izvedbe zagotoviti takšno raven varnosti in zavarovanja, ki ustreza predvidenemu tveganju. Tveganje predstavlja zlasti vsako dejanje, storitev ali izdelek, ki posega $\mathrm{v}$ tajnost, zaupnost in varnost elektronskega komunikacijskega omrežja ali elektronske komunikacijske storitve, s tem ko spremeni dostopnost, vsebino, ceno ali kakovost storitve, in ki ga lahko operater sam ali skupaj z drugimi operaterji učinkovito onemogoči (145. člen ZEKom-1).

Ukrepi morajo vsaj:

- zagotoviti, da ima dostop do osebnih podatkov le pooblaščeno osebje za z zakonom dovoljene namene,

- varovati shranjene ali poslane osebne podatke pred nenamernim ali nezakonitim uničenjem, nenamerno izgubo ali spremembo ter nepooblaščenim ali nezakonitim shranjevanjem, obdelavo, dostopom ali razkritjem, in

- zagotavljati izvajanje varnostne politike pri obdelavi osebnih podatkov.

V primeru, ko gre za posebno tveganje za varnost omrežja mora izvajalec javnih komunikacijskih storitev takoj, ko za to tveganje izve, z objavo na svojih spletnih straneh in na drug primeren način obvestiti naročnike o takem tveganju. Če tveganje presega obseg ukrepov, ki jih izvajalec storitve lahko sprejme, mora 
hkrati obvestiti naročnike o vseh možnih sredstvih za odpravo tveganja, vključno z navedbo verjetnih stroškov, ter jim omogočiti hiter in učinkovit dostop do zaščitnih ukrepov (1. odst. 146. člena ZEKom-1).

Pomembna je določba 2. odst. 146. člena ZEKom-1, saj pri zlorabah, ki jih storijo tretje osebe in ki niso nastale po krivdi naročnikov ali uporabnikov, izvajalci javnih komunikacijskih storitev prevzamejo stroške zagotavljanja javnih komunikacijskih storitev, ki jim nastanejo kot posledica teh zlorab. Šteje se, da zloraba ni nastala po krivdi naročnika ali uporabnika, kadar je ta uporabil vse razumne ukrepe za zaščito in spoštoval navodila, o katerih ga je obvestil izvajalec javnih komunikacijskih storitev.

ZEKom-1 ureja tudi pošiljanje t.i. spam-a naročnikom, ki so fizične osebe. Uporaba samodejnih klicnih in komunikacijskih sistemov za opravljanje klicev na naročnikovo telefonsko številko brez človekovega posredovanja (npr. klicni avtomati, SMS, MMS), telefaksov ali elektronske pošte za namene neposrednega trženja je dovoljena samo na podlagi naročnikovega ali uporabnikovega predhodnega soglasja. Ne glede na opisano pa lahko fizična ali pravna oseba, ki od kupca svojih izdelkov ali storitev pridobi njegov elektronski naslov za elektronsko pošto, ta naslov uporablja za neposredno trženje svojih podobnih izdelkov ali storitev pod pogojem, da kupcu ponuja jasno in izrecno možnost, da brezplačno in enostavno zavrne takšno uporabo svojega elektronskega naslova takrat, ko so ti podatki za stike pridobljeni in ob vsakem sporočilu v primeru, da kupec ni zavrnil takšne uporabe že na začetku (t.i. opt-out).

Uporaba drugačnih sredstev za neposredno trženje $\mathrm{z}$ uporabo elektronskih komunikacij, je dovoljena le s soglasjem naročnika ali uporabnika. ZEKom-1 tudi izrecno določa, da mora biti zavrnitev soglasja za zadevnega naročnika ali uporabnika brezplačna. Pri uporabi govornih telefonskih klicev je treba upoštevati tudi določbe tretjega, četrtega in petega odstavka 150. člena ZEKom1.

Dodatno omejitev pozna ZEK-om-1 v 5. odst. 158. člena, kjer izrecno prepoveduje pošiljanje elektronske pošte za namene neposrednega trženja $\mathrm{v}$ nasprotju z zakonom, ki ureja elektronsko poslovanje na trgu (ZEPT ${ }^{4}$ ), tako, da se skrije ali prikrije identiteta pošiljatelja, $v$ imenu katerega se sporočilo pošilja, in

\footnotetext{
${ }^{4}$ Zakon o elektronskem poslovanju na trgu (Uradni list RS, št. 61/06, 45/08, 79/09, 96/09, 19/15).
} 
brez veljavnega naslova, na katerega lahko prejemnik pošlje zahtevo za prenehanje pošiljanja takih sporočil. Prav tako je prepovedano pošiljanje elektronske pošte za namene neposrednega trženja, ki vabi prejemnike, da obiščejo spletne strani, ki so v nasprotju z ZEPT.

\section{$8 \quad$ Sklep}

EU je s sprejetjem Splošne uredbe brez dvoma postavila nov mejnik pri prizadevanju za varstvo pravic posameznikov glede njihovih osebnih podatkov. Čas bo seveda pokazal kako se bodo določbe Splošne uredbe uporabljale v praksi, vendar prve odločitve nadzornih organov v posameznih državah članicah EU nakazujejo strogo in dosledno uporabo določb Splošne uredbe.

Področje varstva podatkov že dolgo tudi ni več domena pravnikov, saj vse pogosteje terja interdisciplinaren pristop. Informacijska tehnologija namreč omogoča nove in nove storitve, $\mathrm{v}$ okviru katerih se lahko obdeluje velika količina osebnih podatkov, nekateri tudi izključno avtomatizirano. Prav velike količine osebnih podatkov pa predstavljajo ne samo veliko vrednost ampak tudi veliko obveznost. Zato je za vsakega upravljavca zelo pomembno, da postopke obdelave osebnih podatkov izvaja tako, da zagotavlja ustrezne tehnične in organizacijske ukrepe za njihovo varstvo, preprečuje varnostne incidente in nadzira obdelave osebnih podatkov pri pogodbenih obdelovalcih. Pri tem si lahko pomaga z pooblaščeno osebo za varstvo osebnih podatkov, $v$ primerih kjer bi obdelava predstavljala veliko tveganje za pravice posameznikov pa izdela tudi oceno učinka.

\section{Zakonodaja, pravni viri}

Direktiva Sveta 93/13/EGS z dne 5. aprila 1993 o nedovoljenih pogojih v potrošniških pogodbah (UL L 95, 21.4.1993)Zakon o elektronskih komunikacijah, ZEKom-1 (Uradni list RS, št. 109/12, 110/13, 40/14, 54/14, 81/15 in 40/17)

Predlog ZVOP-1, Poročevalec DZ, EVA 2004-2011-0001 z dne 25. 3. 2004

Uredba (EU) 2016/679 Evropskega parlamenta in Sveta z dne 27. aprila 2016 o varstvu posameznikov pri obdelavi osebnih podatkov in o prostem pretoku takih podatkov ter o razveljavitvi Direktive 95/46/ES (Splošna uredba o varstvu podatkov), OJ L 119, 4.5.2016

Ustava Republike Slovenije, Uradni list RS, št. 33/91-I, 42/97, 66/2000, 24/2003, 47, 68, $69 / 04,68 / 06,140,143,47 / 13,97,99$ in $75 / 16$

Zakon o elektronskem poslovanju na trgu, ZEPT (Uradni list RS, št. 61/06, 45/08, 79/09, 96/09, 19/15) 
Zakon o varstvu osebnih podatkov, ZVOP-1, Uradni list RS, št. 86/04, 113/05, 51/07, $67 / 07,94 / 07$

\section{Literatura}

Döpke, C. (2018) The Importance of Big Data for Jurisprudence and Legal Practice, In: Hoeren, T. \& Kolany-Raiser, B. (ur.) (2018) Big Data in Context: Legal, Social and Technological Insights, SpringerBriefs in Law, (Springer Nature), doi: 10.1007/9783-319-62461-7_2, pp. 13-19.

Fuller, C. S. (2016) The perils of privacy regulation, The Review of Austrian Economics, 30(2), pp. 193-214, doi: 10.1007/s11138-016-0345-0.

Miglico, G. (2018) GDPR is here and it is time to get serious, Computer Frand \& Security, 2018(9), pp. 9-12, doi: 10.1016/S1361-3723(18)30085-X.

O'Brien, R. (2017) Privacy and security: The new European data protection regulation and it's data breach notification Requirements, Business Information Review, 33(2), pp. 81-84, doi: 10.1177/0266382116650297.

Politou, E., Michota, A., Alepis, E., Pocs, M. \& Patsakis, C. (2018) Backups and the right to be forgotten in the GDPR: An uneasy relationship, Computer Law \& Security Review, 34(6), pp. 1247-1257, doi: 10.1016/j.clsr.2018.08.006.

Smernice IP RS (2018) Smernice IP RS o oceni učinkov na varstvo osebnih podatkov, pridobljeno na: https://www.iprs.si/fileadmin/user_upload/Pdf/Ocene_ucinkov/Smernice_o_ocenah_ucinka _DPIA_nov2018.pdf (12. 4. 2019)

Sobolewski, M., Mazur, J. \& Palinski, M. (2017) GDPR: A Step Towards a User-centric internet?, Intereconomics, 52(4), pp. 207-213.

Wilson, S. (2018) A framework for security technology cohesion in the era of the GDPR, Computer Frand \& Security, 2018(12), pp. 8-11, doi: 10.1016/S1361-3723(18)301192. 



Knjiga z naslovom Gospodarski subjekti na trgu in evropske dimenzije 2018 je znanstvena monografija več avtorjev samostojnih poglavij. Avtorji analizirajo aktualne pravne položaje v zvezi $s$ pametnimi pogodbami, koncerni in pravnim varstvom delničarjev in upnikov, prepletanjem prostorske in gradbene zakonodaje s stvarnim pravom, medijskim pravom, varstvom podatkov po Splošni uredbi o varstvu podatkov (GDPR) itd. Knjiga vsebuje prispevke s področja javnega in zasebnega prava. Avtorji jasno izražajo svoja stališča, razmejitev med povzetimi in lastnimi stališči posameznih avtorjev je jasna. Prav tako se argumentirano spopadajo s stališči v pravni teoriji in sodni praksi, kar povečuje uporabno vrednost monografije. Delo bo v pomoč vsem, ki se ukvarjajo z različnimi pravnimi vidiki prostorske in gradbene zakonodaje. Obsežno so predstavljeni problemi, do katerih prihaja pri postopkih razlastitve in ustanavljanja služnosti $v$ javno korist. $\mathrm{V}$ knjigi so vključeni tudi zaokroženi prikazi o tehnologijah veriženja blokov in pametnih pogodb, poročilu o odvisnosti kot instrument varovanja delničarjev in upnikov odvisnih družb v koncernu, obrestih od davčnih obveznosti, o dopustnih mejah medijskega poročanja ter varstvu osebnih podatkov. Knjiga nedvomno predstavlja prispevek k razvoju pravne znanosti.

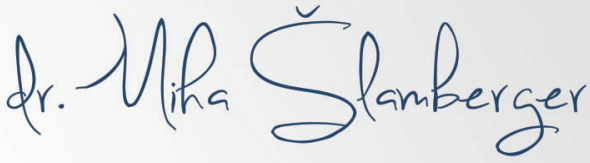

